\title{
A PREDICTIVE MODEL FOR SURVIVAL IN METASTATIC CANCER PATIENTS ATTENDING AN OUT-PATIENT PALLIATIVE RADIOTHERAPY CLINIC
}

by

Edward Chow MBBS, FRCPC

A thesis submitted in conformity with the requirements for the degree of MSc (Clinical Epidemiology), Graduate Department of Health Administration, University of Toronto

(C) Copyright by Edward Chow (2001) 
National Library

of Canada

Acquisitions and Bibliographic Services

395 Wellington Street Ottawa ON KIA ONA Canada
Bibliothèque nationale

du Canada

Acquisitions et services bibliographiques

395, ne Weilington

Ottawa ON KIA ON4

Canada
The author has granted a nonexclusive licence allowing the National Library of Canada to reproduce, loan, distribute or sell copies of this thesis in microform, paper or electronic formats.

The author retains ownership of the copyright in this thesis. Neither the thesis nor substantial extracts from it may be printed or otherwise reproduced without the author's permission.
L'auteur a accordé une licence non exclusive permettant à la

Bibliothèque nationale du Canada de reproduire, prêter, distribuer ou vendre des copies de cette thèse sous la forme de microfiche/film, de reproduction sur papier ou sur format électronique.

L'auteur conserve la propriété du droit d'auteur qui protège cette thèse. $\mathrm{Ni}$ la thèse ni des extraits substantiels de celle-ci ne doivent être imprimés ou autrement reproduits sans son autorisation. 


\title{
MSc Thesis
}

\section{A Predictive Model for Survival in Metastatic Cancer Patients Attending an Out-Patient Palliative Radiotherapy Clinic}

\author{
Student: $\quad$ Edward Chow MBBS, FRCPC \\ Radiation Oncologist \\ Supervisor: $\quad$ lan Tannock MD, PhD, FRCPC \\ Medical Oncologist \\ Committee Members: $\quad$ Andrea Bezjak MD, MSc, FRCPC \\ Radiation Oncologist \\ Tony Panzarella MSc \\ Statistician
}


A predictive model for survival in metastatic cancer patients attending an outpatient palliative radiotherapy clinic

Edward Chow MBBS, FRCPC

For the degree of MSc (Clinical Epidemiology), Graduate Department of Health Administration, University of Toronto, 2001

Aim:

To develop a predictive model for survival in a palliative radiotherapy clinic.

\section{Methods and Materials:}

Sixteen factors were analyzed prospectively by multi-variate regression.

\section{Results:}

Six prognostic factors - primary site, site of metastases, KPS, fatigue, appetite and shortness of breath - provided a survival prediction score (SPS). Patients were divided into 3 groups. Group A (SPS $\leq 13$ ) with survival probability at 3,6 , and 12 months of $83 \%, 70 \%$, and $51 \%$ respectively; Group B (SPS $=14-19): 67 \%, 41 \%$, and $20 \%$; and Group C (SPS $=20-32$ ): $36 \%, 18 \%$, and $4 \%$. Stratification was also performed by number of risk factors. Corresponding survival probabilities were: Group I ( $\leq 3$ risk factors): $85 \%, 72 \%$, and $52 \%$; Group II (4 risk factors): $68 \%, 47 \%$, and $24 \%$; and Group III ( $\geq 5$ factors): $46 \%, 24 \%$, and $11 \%$.

\section{Conclusion:}

The model appears promising but requires validation. 
Page

Abstract.

Acknowledgements iv

Chapter 1: Introduction. 1

Rationale / Relevance. 2

Review of Literature ............................................................... 4

Summary of Current Literature .................................................... 9

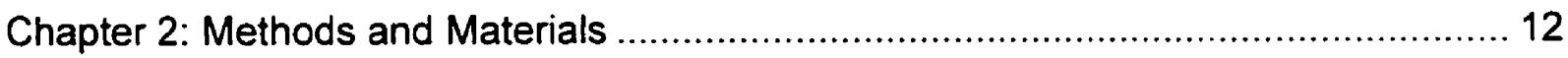

RRRP Database...................................................... 12

Development of a Predictive Model................................. 14

Item Generation.............................................. 14

Continuous Versus Categorical Data ........................... 15

Statistical Analysis .............................................................. 17

Primary Outcome ........................................................ 17

Handling of Missing Data .............................................. 17

Minimum Subject Requirements ................................... 18

Item Reduction ........................................................... 18

Model Selection .............................................................. 19

Univariate Analysis..................................................... 20

Multivariate Analysis .................................................. 21

Risk Group Statification.............................................. 22

Means for Studying Predictive Accuracy .............................. 24 
Chapter 3: Results

Demographics

Univariate Analysis of Effects of Prognostic Factors on Survival............... 29

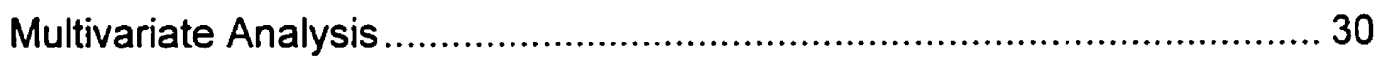

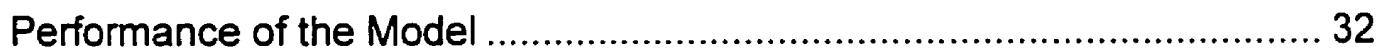

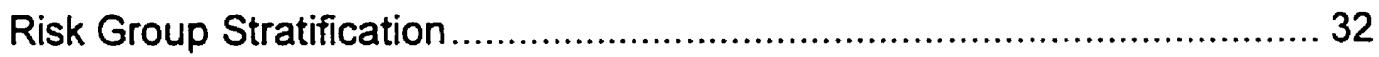

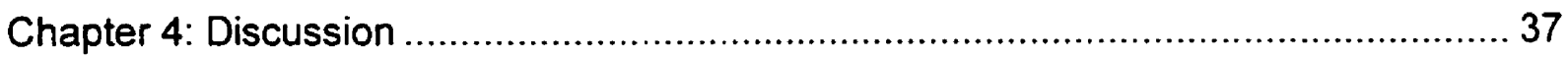

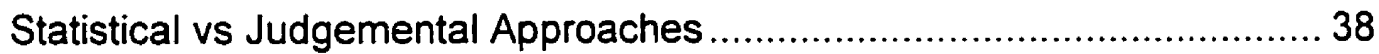

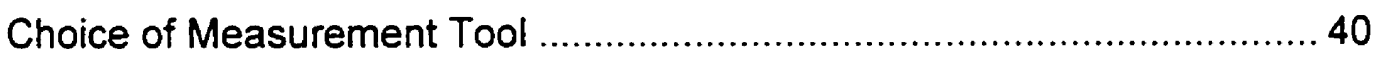

Choice of Co-Variates in Item Generation ...............................................4 41

Difference in Median Survival and KPS................................................ 43

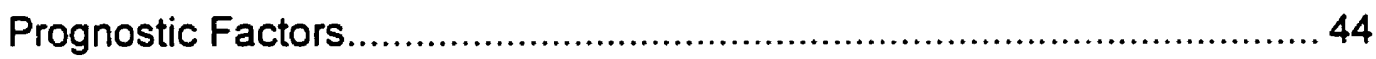

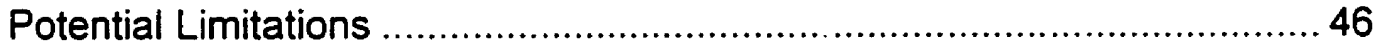

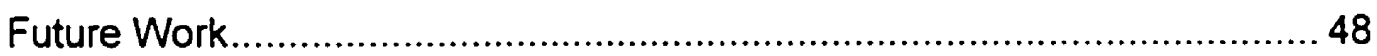

Potential Use of the Model ....................................................................... 49

Application of the Future Validated Model ..............................................51

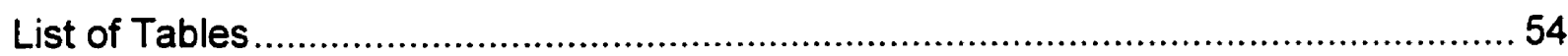

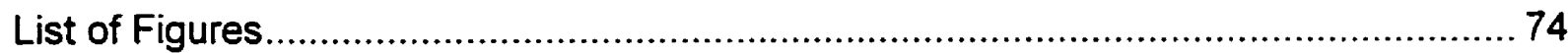

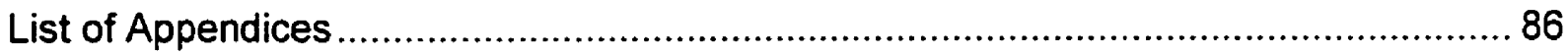

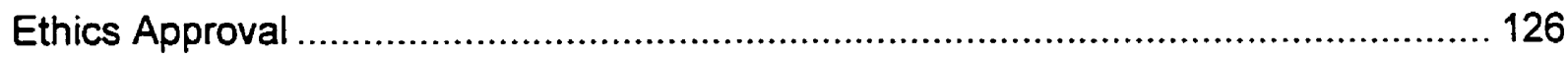

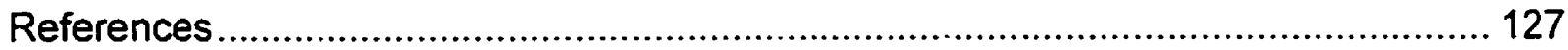


We thank the following members of the Rapid Response Radiotherapy Program at the Toronto-Sunnybrook Regional Cancer Centre for their contribution to the prospective database:

Radiation Oncologists

Dr. C. Danjoux

Dr. C. Hayter

Dr. A. Loblaw

Dr. E. Szumacher

Dr. R. Wong

Radiation Therapists

Ms. R. Connolly

Ms. L. Holden

Nurses

Ms. L. Andersson

Ms. J. Pope

Statisticians

Ms. E. Franssen

Ms. K. Fung

Data Entry Research Assistants

Ms. R. Norton-Tkalec

Ms. L. Wyles

and Dr. M. Fitch's students

We thank Ms. D. Nywening for secretarial assistance.

This project is partly funded by the Department of Radiation Oncology, University of Toronto, Geoffrey H. Wood Foundation Grant, Toronto-Sunnybrook Regional Cancer Centre Radiation Program Fund and Cancer Care Ontario. 
When cancer advances to a stage that control or curative therapy is no longer an appropriate or desired treatment option, one of the issues addressed frequently by patients and families is estimating the remaining time of survival.

Unfortunately, studies have shown that it is difficult to estimate accurately the survival once the disease is progressive and uncontrollable.

The classification of patients with advanced cancer into groups with similar and predictable survival has the potential to lead to improvement in therapeutic and care strategies, and to minimize risks of undertreatment or overtreatment. 
Predicting the life expectancy of terminally ill cancer patients is one of the most difficult and least welcomed tasks in the oncology and palliative care community. However, such an estimate is of vital importance for patients and their families to confront end-of-life issues and plan their remaining time together. Medical professionals and health care administrators also require such estimates to guide appropriate clinical decisions, plan supportive services and allocate resource utilization (1).

Physicians are often required to predict patient survival at times of referral to hospice programs and enroliment into clinical trials (2). However, cinicians are often overly optimistic in the survival prediction of terminally ill cancer patients $(3,4)$. A 1993 report from the U.S. National Hospice Organization showed that more than $50 \%$ of patients with end of life cancer were not given access to hospice programs (5) or were referred too late in the course of their illness to take full advantage of the available hospice services (6). Pessimistic prediction also happens but is less common (7).

This group of fragile patients is prone to sudden death from unexpected events such as infection and bleeding (8). Inaccurate prediction of survival often results in inadequate access to palliative care. Optimistic prediction may deter patients from being involved in palliative programs at an earlier stage. Patient preferences about the trade-off between the risks and benefits associated with treatment strategies are 
often based on perceptions of prognosis. Inaccurate perceptions can lead to unrealistic expectations (2). Weeks and colleagues found that patients with optimistic prognostic misperceptions often request medical therapies that most physicians would consider futile. These same patients were 8.5 times as likely to favor receiving aggressive, life-extending medical care than were patients with more accurate estimates of their 6-month survival. More disturbingly, those with overly optimistic prognoses were more likely to die in hospital on mechanical ventilation than were those patients with more realistic estimates of their survival potential. The authors suggest that terminal cancer patients' optimistically miscalibrated prognostic estimates may lead them to choose highly aggressive, invasive and ultimately futile medical care rather than palliative care (9).

Other than the clinicians' impression, survival prediction can be made from clinical parameters, biochemical variables, or a combination of both. Studies employing performance status, patient symptomatology, quality of life measures and biochemical parameters have been performed to complement the clinicians' estimates (10-12).

Terminally ill cancer patients represent a heterogeneous group, ranging from ambulatory and independent to moribund and bed-bound. Constructing common prognostic predictors for such a diverse group poses challenges to investigators (13). Moreover, most of these studies are observational in nature and are based on small retrospective series, thus making comparisons across studies difficult. 


\section{Review of Literature}

Two recent systematic reviews have been performed on the survival prediction of terminally ill cancer patients $(14,15)$, one of which $(14)$ was performed as part of the preparation for this thesis.

The objectives of our review were to examine the predictive ability of prognostic factors and to determine the accuracy of physicians' estimates in predicting the survival of terminal cancer patients (14). A Medline search was conducted of articles in English published between 1966 and March 2000 concerning survival prediction of terminally ill cancer patients. The keywords used for the search included "forecasting/clinical prediction", "prognosis/prognostic factors", "survival" and "neoplasm metastasis". Additional articles were identified by performing searches in Cancerlit (1983 - March 2000), Embase (1991 - March 2000), Pubmed (1966 March 2000), Cochrane and from the reference sections of the relevant articles and reviews.

Studies were included if they met the following criteria: a) patients aged 18 and above were included and $b$ ) the study included a range of histologies representative of those seen in hospices, palliative care programs and outpatient palliative oncology settings. Since it is not common practice to perform routine blood work in these patients, studies utilizing biochemical and molecular markers were generally excluded. 
Articles on clinicians' prediction of survival and prognostic factors are all descriptive studies (category of evidence: III) (Appendix 1). However, if they represent welldesigned cohort studies, especially from more than one center or research group, their levels of evidence become II - a (table 1). For studies testing prognostic factors, those that have adequate sample sizes to test for independent predictors (at least 10 outcome events per variable tested), and were subsequently validated, will constitute level II - a evidence (table 2).

Three hundred and eighty-one abstracts were found. Manual checking of abstracts was performed in order to select appropriate articles as outlined in the inclusion/exclusion criteria. Articles confined to one primary cancer site, or those utilizing biochemical and molecular studies were excluded. Twelve articles on clinicians' prediction and nineteen articles on prognostic factors were identified to examine these aspects of clinical prediction of survival in terminally ill cancer patients. Clinicians' prognostic accuracy was assessed by comparing patients' actual survival to the predicted survival. Results of the studies are summarized in table $1(3,4,7,16-24)$.

Clinicians' prediction of survival was based on the clinical experience of the physicians and the para-medical staff. The estimates of survival reported in table 1 were obtained from a diverse group of physicians and health care professionals. 
In general, clinicians' overall survival estimates tended to be inaccurate in the optimistic direction in nine of the twelve studies $(3,4,7,16-19,23,24)$. The definition of 'optimistic error' varied among studies but it is clear that patients often do not live as long as their physicians predict.

Prognostic determinants for terminally ill cancer patients have been increasingly investigated in the last two decades. Nineteen articles were identified which examined the prognostic indicators of survival. They are listed in table $3(7,10,11$, $16,18-20,25-35)$.

To determine prognostic predictors, multivariate analysis is often employed following the evaluation of each variable that is statistically significant in univariate analysis. A large number of outcome events are needed if many variables are included in the analysis. In general, results of models having fewer than 10 outcome events per independent variable are thought to have questionable accuracy $(36,37)$ and the usual tests of statistical significance may be invalid. Several studies $(11,18,29,31$, 32) suffer from this deficiency. As with all statistical models, the results of multivariate analyses require validation to protect against unrecognized problems and limitations (38). Common methods for validating models include 1) performing a test analysis on a sub-sample of patients followed by a subsequent validation analysis on the remaining patients; 2) repeating the analysis on an independent sample of patients; and 3) using the 'jackknife' or 'bootstrap' procedures (39) in which the same analysis is performed multiple times on a series of subsets from the 
same data set in order to evaluate the stability of the predictive ability of the model. Only a few studies underwent such validation processes $(20,35,40)$ (table 2).

Among all prognostic determinants, performance status appears to be an independent prognostic factor in at least 13 of the studies $(7,10,16,19,20,25-27$, $29,31,33-35,40$ ). The Karnofsky Performance Scale (KPS) is the most widely used tool to quantify the functional status of cancer patients $(41,42)$. The KPS is an 11 -point rating scale which ranges from normal functioning $(100)$ to dead $(0)$ (Appendix 2).

Yates and associates observed that KPS scores accurately predicted early deaths, but high initial KPS scores did not necessarily correlate with long survival (25). Mor et al further confirmed the direct relationship between KPS and survival $(p<0.001)$ and found that lower KPS levels were likely to represent a "death-imminent" status, suggesting a high specificity for lower KPS levels (26).

In light of the potential limitations of KPS, the assessment of clinical symptoms in combination with KPS and clinicians' prediction was employed in a large study by Reuben et at (10) to help improve the ability to predict survival. They used data from the National Hospice Study (NHS), a multicentre study that compared hospice and conventional terminal care in $\mathbf{4 0}$ hospices and 14 non-hospice medical care settings. Fourteen symptom-related items together with KPS were analyzed on a total of 1592 patients. They found that in addition to performance status, which was the most 
statistically significant clinical factor in estimating survival time, five other symptoms also had independent prognostic values. These were shortness of breath, eating problems or anorexia, trouble swallowing, dry mouth and weight loss. The prevalence of these symptoms among patients with cancer of various primary and metastatic sites supports the concept of a common final clinical pathway in patients with advanced malignancies - the terminal cancer syndrome (10). This observation has also been reported by other investigators $(27,31)$. Prognostic indicators of survival in other studies are detailed in table 3 and in the following summary. 
1. Functional or performance status was best correlated with the length of survival in 13 studies $(7,10,16,19,20,25-27,29,31,33-35)$.

2. Anorexia, weight loss and dysphagia were the next strongest predictors for survival as demonstrated in 7 of the studies $(10,18,20,27,34,35,40)$. These symptoms comprise part of the 'terminal cancer syndrome' as identified by Reuben et al (10).

3. Cognitive failure and confusion were associated with shorter life span in 3 studies $(11,18,34)$. The site of the primary and extent of metastatic disease were predictive of survival in 2 studies $(29,32)$.

4. Clinicians' predictions tended to be overly optimistic $(3,4,7,16-19,23,24)$.

There is fair evidence (grade B) to support using performance status and clinical parameters together with clinicians' prediction to help survival prediction. However, there is weak evidence (grade $D$ ) to support that clinicians' prediction alone be employed for the prediction of survival (Appendix 1 ) and in fact they can be misleading. 
Vigano et al performed a similar systematic review and concluded:

1. variables definitely associated with decreased survival were: low performance status, clinical estimation of survival, cognitive impairment, anorexia, dyspnoea, xerostomia, weight loss, and dysphagia;

2. variables possibly associated were: male gender, primary cancer site, pain, serum albumin, and tachycardia;

3. variables probably not associated were: increasing age, fever, marital status, nausea, and anaemia (15).

The two systematic reviews were on prognostic factors for survival in end-stage cancer patients, regardless of their original primaries. These prognostic factors were generally available in regular clinical practice $(14,15)$.

Most studies were in hospice settings and only one article was in a palliation setting employing radiation as a palliative modality. Grabowski et al in their article "Factors predictive of completion of treatment and survival after palliative radiation therapy" analyzed 12 variables in 97 patients undergoing palliative radiation and concluded that performance status, site of primary, and solitary vs. multiple metastases were predictors (29). However, Harrell et al have provided arguments that for regression modeling, the number of events (deaths) should be at least ten times the number of 
potential prognostic parameters (i.e. degrees of freedom) that could be included in the model; otherwise, the model will have questionable accuracy and usual tests of statistical significance become invalid (36). Grabowski's model therefore suffered from 'overfitting'. Furthermore, there is no mention in their paper as to whether the results of the multivariate analysis have been validated for an independent group of patients to protect against unrecognized problems and limitations.

In summary, most studies are small, retrospective series with statistical errors and lack of validation. In particular, there is no existing well-developed and validated predictive model in the setting of an out-patient palliative radiotherapy clinic. Approximately $50 \%$ of the work load in radiation oncology practice is symptom palliation. The choice of optimal radiotherapy dose fractionation is often based on the radiation oncologist's estimate of patients' survival. The objective of this thesis was to develop a predictive model for survival in an out-patient palliative radiotherapy clinic to assist with (1) prognosis, (2) therapeutic decision making, for example, end of life planning and radiotherapy dose fractionations, and (3) =ligibility requirements for enrollment and stratification in clinical trials. 


\section{Chapter 2: Methods and Materials}

At the Toronto-Sunriybrook Regional Cancer Centre, the Rapid Response Radiotherapy Program (RRRP), a pilot program in Ontario, was started in 1996 to provide timely palliative radiotherapy. The intent of the program was to provide quick access to radiotherapy to relieve suffering and improve quality of life in this group of patients with terminal cancer. Their care is shared with community care physicians who continue to provide the overall management of palliative care. Resources are mobilized so as to allow consultation and radiotherapy to occur on the same day to reduce unnecessary difficult trips for patients to cancer centers. The referrals are mainly from the oncologists and palliative care physicians in the Greater Toronto Area.

\section{RRRP Database}

A prospective database has been set up for patients referred for palliative radiotherapy at RRRP since January 1999 (Appendix 3). We accept referrals of new patients with metastatic cancer who have not seen previously a radiation oncologist at our centre. Other patients continue to receive care from their own radiation oncologists. The referral requires a pathological diagnosis of cancer and documentation of metastatic disease either by pathological confirmation, clinical examination or imaging studies. Patients were enrolled into the database if they were able to speak English, give verbal consent and complete symptom assessment. Patients were excluded from the database if they were confused, 
refused, or were unable to complete the symptom assessment. Patients in the prospective database seen in the calendar year of 1999 served as a training set to develop the predictive model for survival. Ethical approval was obtained for this project.

During the initial consultation, patient demographics, cancer history, disease status and symptom profiles were collected. Patients were asked to rate their symptom distress using the modified Edmonton Symptom Assessment Scale (ESAS). This includes a total of 9 symptoms (pain, fatigue, nausea, depression, anxiety, drowsiness, appetite, sense of well-being and shortness of breath) using an 11 point categorical scale $(0-10,0=$ lack of symptom, $10=$ worst possible symptom). The equivalent total daily dose of oral morphine for initial analgesic consumption during the preceding 24 hours was recorded. Analgesic consumption at the first visit was classified as none, non-opioids, weak opioids (e.g. codeine) and strong opioids (e.g. morphine and hydromorphone).

Two health care professionals (a nurse and a radiation therapist) have been trained to collect the data including the modified Edmonton Symptom Assessment Scale scores. If one of them was absent from the clinic due to vacation, conference or sick leave, no collection of data in that particular clinic took place because of the heavy clinical workload. Data entry was performed by our research assistants using the Oracle Database System. 
The survival status and the date of death or last follow-up of the patients in the prospective database were obtained from the Cancer Death Registry or by telephone calls to patients and their families.

\section{Development of a Predictive Model}

\section{Item Generation}

Based on the systematic review and clinical experience, information about the following factors was collected prospectively for this study.

1. Age at first consultation in the palliative radiotherapy clinic

2. Primary cancer site (breast, prostate, lung and others)

3. Sites of metastases (bone only vs others)

4. Weight loss

5. Karnofsky Performance Status (KPS)

6. Time from first diagnosis of cancer to first consultation in the palliative radiotherapy clinic (months)

7. Analgesic consumption within 24 hours prior to first consultation

8. Pain

9. Fatigue

10. Nausea

11. Depression

12. Anxiety

13. Drowsiness 


\section{Appetite}

15. Sense of well-being

16. Shortness of breath

\section{Continuous Versus Categorical Data}

Although the handling of variables as continuous has the advantage of retaining all the information, it may not be clinically practical to physicians when the outcome is reported in terms of hazard ratio per unit increase which may be difficult to interpret. It may be easier to work with categorical variables. Categorization into several subgroups is preferable if one wants to retain more information. This would also allow some idea of how the risk varies across the range of values of the prognostic factor. The choice of the best cut-off for continuous characteristics is important. The median value or the quartiles of variable distribution are commonly used to divide patients into two or more subgroups if clear clinical-biological criteria are not available. However, it is not certain that this approach can identify the cutoff with the best discriminating capacity. Selecting a cut-off point to distinguish risk groups by computing a statistical significance level for all possible cut-off points and then selecting the one with the smallest significance level is another alternative.

Of the 16 potential prognostic factors (known as co-variates), we dichotomized the following:

a) age at first consultation for palliative radiotherapy at the median age of 68 (> 68 vs $\leq 68)$ 
b) site of metastases (bone only vs others)

c) weight loss ( $\geq 10 \%$ over 6 months vs $<10 \%$ )

d) Karnofsky Performance Status (KPS) (> 50 vs $\leq 50$ )

e) time from first diagnosis of cancer to first consultation in the palliative radiotherapy clinic (> 12 months vs $\leq 12$ months)

We categorized the remaining co-variates into 4 subgroups.

Primary cancer site had 4 subgroups: breast, prostate, lung, and others.

Analgesic consumption in the preceding 24 hours was categorized as:

a) none

b) non-opioids

c) weak opioids (e.g. codeine)

d) strong opioids (e.g. morphine and hydromorphone)

This grouping was common in palliative radiotherapy trials for bone metastases (43 $-51)$.

The severity of pain has been classified into none $(0)$, mild $(1-3)$, moderate $(4-7)$, and severe $(8-10)$ in the literature $(43,45-50,52-55)$. In order to avoid different cut-off points for the 9 symptoms, we subdivided all the nine symptoms in ESAS into the same 4 subgroups. To test the robustness of this approach, we also analysed the data by using the following alternative cut-offs:

(i) none (0), mild ( $1-4)$, moderate $(5-7)$, and severe $(8-10)$;

(ii) none $(0-1)$, mild $(2-4)$, moderate $(5-7)$, and severe $(8-10)$. 


\section{Primary Outcome}

Time to death from all causes was taken as the primary outcome. Patients who were lost to follow-up were censored at their last clinic visit. Patients who were still alive at the time of reporting were censored on the date of the telephone interview which established their status. Survival times were measured from the date of first consultation at RRRP.

\section{Handling of Missing Data}

Patients who were included in the database were compared with those not included. The following characteristics that could be obtained from the electronic medical records at the cancer centre were used for the comparison:

1. Age at first visit

2. Gender

3. Primary cancer site

4. Overall survival

Among patients included in the database, any co-variates with at least $20 \%$ missing values were eliminated from the analysis following a recommendation by Stephen George in his paper "Identification and assessment of prognostic factors" (56). If the co-variate had less than $20 \%$ missing values, we estimated the missing value with the median of that co-variate (method 1). To test the robustness of method 1 we also employed the following methods: 
Method 2: Discarding the subjects with the missing data.

Method 3: Matching other patients with similar co-variate characteristics (age at first visit, primary cancer site, site of metastases, weight loss, KPS, time from first diagnosis of cancer to first consultation at our clinic, and the analgesic consumption) and replacing the missing value with the mode of that co-variate .

Method 4: Assigning a random number generated by the computer to the missing value.

\section{Minimum Subject Requirements}

When separating the patients into prognostic subgroups on the basis of differences within a co-variate, for a co-variate to be potentially prognostic, one would expect a substantial difference in outcomes among the subgroups. A minimum number of subjects is required in each subgroup for comparisons to be meaningful (56). We required arbitrarily at least 15 subjects in each subgroup.

\section{Item Reduction}

The purposes of item reduction employing univariate and multivariate analyses are 3-fold:

1. To eliminate redundant or inappropriate items.

2. To reduce the model to a manageable and feasible number of items.

3. To create a sensible and valid prognostic model. 


\section{Model Selection}

The prognostic factor analysis was based on utilizing the Cox proportional hazards model (57), which can be expressed as

$$
h_{i}(t)=h_{0}(t) \times \exp \left(b_{1} x_{1 i}+b_{2} x_{2 i}+\ldots+b_{p} x_{p i}\right)
$$

where $h_{i}(t)$ represents the hazard, or the instantaneous risk of suffering the event of interest, of patient $i$ at time $t$, conditional on having been followed event-free to time $t ; h_{i}(t)$ is a function of a patient's underlying hazard $h_{0}(t)$ and co-variates $x_{\mathrm{ji}}$, whose corresponding regression coefficients are represented by $b_{j}$.

The strategy for model selection was based on the hierarchic principle involving nested models. The underlying idea is that the adequacy of the fit of 2 models can be compared if the 2 models are nested. That is, the co-variates in the first model are completely contained in the second model, which has 1 or more additional covariates. These additional co-variates can be assessed for their association with outcome by comparing the $-2 \times \log$ (maximized likelihood function) (-2LL) for these 2 models. In general, the maximized likelihood function for a model is a joint probability function involving at least one unknown parameter, which when solved for by the method of maximum likelihood, maximizes the probability of observing the data actually observed. Therefore, this statistic measures the extent to which the data are fitted by the model. The difference in this statistic for the nested models (referred to as the likelihood ratio test) has, approximately, a chi-squared distribution under the null hypothesis that the regression coefficients of these co-variates are zero (i.e. these additional co-variates have no association with outcome). The 
number of degrees of freedom for this chi-squared distribution is the difference in the number of parameters being fitted in the 2 models.

\section{Univariate Analysis}

Each of the 16 co-variates was first examined individually for its association with outcome using Cox's proportional hazards model and the likelihood ratio test (see above). As each of the co-variates was defined as a categorical variable, one or more dummy variables (i.e. 0/1) were used in each case. In general, for $k$ categories k-1 dummy variables are required. For example, for primary site each of the sites lung, prostate and others is explicitly defined by either a 1 (if patient belongs to that site) or 0 (patient does not belong to that site). Implicit in this is that the fourth primary site category (breast), is defined when each of the 3 indicator variables equals zero.

To protect against overfitting of the model, a rule of thumb suggested by Harrell et al. was incorporated; namely, the number of events (deaths) should exceed the number of potential co-variate degrees of freedom by a ratio of at least $10(36)$. To this end and to adjust for multiple comparisons based on the multiple co-variates under consideration a significance level of $1 \%$ was chosen to guide decisions for covariate inclusion in the subsequent multivariate analysis. 
Univariate results were illustrated using Kaplan-Meier survival plots (58) and survival curves were compared using the log rank test or, if the co-variate was ordinal, the log rank test for trend (59).

\section{Multivariate Analysis}

Co-variates found to be statistically significant from the univariate analysis were then fitted jointly into a Cox model. In the presence of multiple co-variates, some might cease to be important. Each co-variate starting from the least statistically significant was dropped individually from the model and the $-2 L L$ 's from the nested models were compared with and without that co-variate. If the value of the difference in $-2 \mathrm{LL}$ was not increased significantly, the co-variate was discarded. Once a co-variate was dropped, the effect of omitting each of the remaining co-variates in turn was examined.

Co-variates from the univariate analysis, which were not statistically significant on their own, were at this point re-introduced into the model, one at a time. This acknowledges the possibility that in the presence of other co-variates these covariates might show themselves to be statistically significant. This process may also result in co-variates found previously to be statistically significant losing their significance.

The above procedure avoids the use of a rigid significance level, so the multivariate analysis used a $10 \%$ level of significance to guide decisions about co-variate entry 
or omission (60). The results of the multivariate analysis were summarized using P. values and $95 \%$ confidence intervals for co-variate hazard ratios (HR). A HR is a ratio of the risks for different subgroups of a co-variate. For example, for a binary co-variate such as gender where males are coded as 1 and females 0 , a hazard ratio of 1.75 would imply that the risk of dying among males is 1.75 times higher than among females.

\section{Risk Group Stratification:}

\section{Partial Score Method}

This approach was employed in the studies of survival prediction by Italian and Japanese investigators $(34,35)$. In order to obtain an easy-to-handle prognostic score for the prognostic factors retained in the final model, the value of each statistically significant regression co-efficient was divided by the smallest statistically significant regression co-efficient using a $10 \%$ level of significance and the results were rounded to the nearest integer, or to the nearest integer +0.5 . They were then multiplied by 2 to obtain whole numbers (partial scores). The survival prediction score (SPS) for a given patient was obtained by adding together his/her appropriate partial scores. Three risk groups with approximately equal numbers of patients in each group based on the SPS were modeled. 


\section{Number of Risk Factors Method}

One method of risk group identification is based on the total number of risk factors a patient possesses. This approach was adopted in constructing the International Index for aggressive Non-Hodgkin's Lymphoma (61). The final prognostic covariates from the multivariate analysis in general were classified as risk factors. For those co-variates with more than 2 subgroups, only those subgroups with a significant $p$ value $(<0.1)$ were classified as risk factors (table 11 ).

\section{Prognostic Index /Nomogram Method}

The third approach used to estimate prognosis in new subjects employed the prognostic index $(\mathrm{PI})$ from a Cox regression model. The term in the Cox regression model by which the co-variates of the subject affect his/her hazard is $b_{1} x_{1 i}+b_{2} x_{2 i}+$ $\ldots+b_{p} x_{p i}$. Denoting this expression PI, the Cox model equation simplifies to $\lambda(t, x)$ $=\lambda_{0}(t) e^{P I}$.

Estimation of $\mathrm{Pl}$ for a given subject was the first step in estimating the prognosis of that subject. The PI for a subject defined his/her place within the prognostic 'spectrum' defined by the model. The PI could be utilized further in the estimation of a survival curve, the probability of surviving for a given time and the median survival time for the subject. 
From the Cox model, the cumulative survival probability $S(t, x)$ was estimated corresponding to any combination of the co-variates $x=x_{1} \ldots x_{p}$. From equation $\lambda(t, x)=-\log _{e} S(t, x)$, solving for $S(t, x)$ this became $S(t, x)=e^{-i,(t, x)}$. Following from

the assumption of proportionality of the Cox model, $\lambda(t, x)=\lambda_{0}(t) e^{P I}$. Since $\lambda_{0}(t)$ was estimated in a Cox analysis for the whole range of time $t$ from zero to the longest observation time, it was thus possible using these equations to estimate $\lambda(t, x)$ and then $S(t, x)$, which was the estimated survival curve corresponding to a given value of $\mathrm{PI}$ or a given combination of co-variates. For a subject having the co-variates giving a certain $\mathrm{PI}$, the median survival time was estimated as the time $t$ for which the estimated median survival curve $S(t, x)$ reached 0.5 . This was repeated for the whole range of the possible $\mathrm{PI}$ values (62). This approach has been employed in the literature $(63,64)$. The probabilities of survival at 3,6 , and 12 months and the median survival for the possible combinations of $\mathrm{PI}$ were computed in the nomogram.

\section{Means for Studying Predictive Accuracy}

Indices of predictive accuracy are useful for judging the clinical utility of a predictive model and for comparing the merits of competing predictive models. There are two major components of predictive accuracy: calibration (reliability) and discrimination.

Calibration refers to the amount of agreement between predicted and observed outcomes. For example, if the patients of a given risk group are predicted to have 
an $80 \%$ chance of surviving at least 6 months, then $80 \%$ of such patients should survive at least 6 months if the model is reliable.

A list of survival probabilities was generated at all the event times for our 395 patients, based on the values of the selected co-variates in the final model for each patient. All patients were divided randomly into 8 groups (approximately 50 in each). The average predicted survival probability of patients against the actual fraction of patients surviving past 3, 6 and 12 months within each risk group was plotted.

Discrimination is the ability of a predictive model to discern patients having good outcomes from those having poor outcomes. A model predicting an $80 \%$ likelihood of living 6 months for everyone may have no discrimination ability.

Harrell et al proposed a general- purpose index of predictive discrimination called $\mathrm{C}$ for "concordance". The $\mathrm{C}$ index is the probability that for a randomly chosen pair of patients, the predicted and observed outcomes are concordant, i.e. the patient having the better outcome is the one having the better predicted outcome. A value of 0.5 indicates no predictive discrimination and a value of 1.0 indicates perfect separation of patients with different outcomes (65).

The p-value as a criterion to select statistically significant co-variates allows for the hypothesis of no effect in the given sample to be ruled out but is not a measure of clinical importance. Moreover, finding in a data-set statistically significant co- 
variates does not necessarily mean that a lot is understood about prognosis. In linear regression, the proportion of variability in the outcome which is explained by a model is measured by the multiple correlation coefficient $R^{2}$ and therefore a greater predictive value can usually be assigned to a model with greater $R^{2}$. An analogous measure for the predictive strength of a survival regression model in terms of the amount of explained variability is as follows. As the likelihood is a measure of the explained variation, the difference between the log-likelihood $\operatorname{LL}(\beta)$ of the selected model and the log-likelihood of the model with no covariates $\mathrm{LL}(0)$ can be transformed into a measure of the proportion of explained variation, as follows: 1-exp[-2(LL( $(\hat{\beta})-L L(0)) / N](N=$ number of patients) $(66)$.

\section{Software Package}

All analyses were carried out using SAS software (67). 


\section{Demographics}

A total of 483 patients were seen in consultation at RRRP in 1999. Three hundred and ninety-five patients $(82 \%)$ were included in the database that formed the training set for the predictive model for survival.

Patient characteristics are summarized in table 4. There were 198 male and 197 female patients. The median age was 68 years. Lung, breast, and prostate cancers were the most common primary sites. One third of our patients presented with more than $10 \%$ weight loss over the last 6 months.

One patient was lost to follow-up after the first visit and was censored at that time.

The median survival of the 395 patients was 19.4 weeks (range $0-103$ weeks).

Three hundred and twenty-one patients had died and 74 remained alive at the time of reporting. The median follow-up of the surviving patients was 69 weeks and for the entire group, 18.7 weeks.

Eighty-eight patients were not included in the database. Of those, 73 patients had died and the median survival of this group was 15 weeks. When compared by age at first visit, gender, primary cancer site, status (alive or dead), and median survival, there were no statistically significant differences between patients included and not included in the database (table 5). The overall survival curves of the 2 groups are shown in figure 1. 
Of those included in the database, seventy-six patients (19\%) came from a hospital or hospice at the time of first consultation. Bone metastases were diagnosed in $70 \%$ of the patients and visceral metastases, $69 \%$. One hundred and thirteen patients (29\%) presented with bone metastases only. Seventy-two patients (18\%) were referred because of brain metastases. Other events that stimulated referral were bleeding, shortness of breath, tumour mass, spinal cord compression or cauda equina syndrome.

Within 3 months prior to the first clinic visit, 109 (28\%), 103 (26\%) and $55(14 \%)$ patients had received palliative chemotherapy, hormonal therapy and bisphophonates respectively.

The distribution of analgesic consumption in the study cohort was none in 102 (26\%), non-opioids in 44 (11\%), weak opioids in 54 (14\%) and strong opioids in 195 (49\%). Their median total daily morphine equivalent was $20 \mathrm{mg}$ (range $0-18000$ $\mathrm{mg}$ ). Their symptom distress according to the modified Edmonton Symptom Assessment Scale is listed in table 6. Fatigue was rated as the most severe symptom followed by appetite and poor sense of well-being. Three hundred and twenty eight (83\%) patients were treated with palliative radiotherapy for symptom control. 


\section{Univariate analysis of effects of prognostic factors on survival}

The frequency distributions of the 16 co-variates that were included are shown in

figure 2. Data were complete for age, primary cancer site, site of metastases, weight loss, KPS, and analgesic consumption. None of the remaining 10 co-variates had more than $20 \%$ missing values and each subgroup formed by grouping values of each co-variate had more than 15 patients (table 7). There was no significant correlation among the 16 co-variates.

The missing values were replaced by the median in all analyses. The robustness of this method was tested by other methods and there was no change in the statistical significance, except for pain in method $3(p=0.02)$ (table 8$)$. We analysed the data with our preferred cut-offs for the ESAS symptoms and the other two alternatives for the cut-offs as listed in the methods section. There was again no statistically significant difference. Based on the selection criteria of $p \leq 0.01$ for influence on survival from the univariate analysis, 12 of the 16 co-variates were chosen to enter the initial regression model. The 12 co-variates were primary cancer site, site of metastases, weight loss, KPS, time from first diagnosis of cancer to first consultation at RRRP, fatigue, nausea, depression, drowsiness, appetite, sense of well-being and shortness of breath. Their survival curves are shown in figures 3a-p. The total number of degrees of freedom on entry of selected co-variates into the regression model was 28 (table 9). Since there were 321 deaths in the database, the maximum allowed degrees of freedom was 32 in order to avoid overfitting according to Harrell's rule of thumb (36). The remaining four co-variates were not significant in 
the univariate analysis. They were age at first visit, analgesic consumption within the last 24 hours of clinic visit, pain, and anxiety. They were, however, re-introduced at a later stage in the multivariate analysis as described earlier.

\section{Multivariate analysis}

The model generated from the regression analysis contained 6 significant covariates: primary cancer site, site of metastases, KPS, fatigue, appetite, and shortness of breath (table 10). The overall p values for the co-variates and their hazard ratios are listed in table 10 . The hazard ratio represents the ratio of the risks between that subgroup and the subgroup with the best outcome within that covariate.

For the partial score method, the $p$ value for each subgroup was calculated. The steps for calculating the partial scores were as follows (table 11):

1. Using a $10 \%$ level of significance, the value of each statistically significant regression co-efficient ( $\beta$ ) was divided by the smallest statistically significant regression co-efficient ( $\beta$ of 0.26165 for shortness of breath score $1-3$ ) among all regression co-efficients.

2. The result was rounded to the nearest integer, or to the nearest integer +0.5 .

3. It was then multiplied by 2 to obtain a whole number (partial score).

4. A zero was assigned to the partial score if $p>0.1$. 
The partial score approach could be used in this setting since all variables were categorical and represented by the same dummy variable system as described in the statistical section. Examples of using the partial score method were as follows. The regression co-efficient $(\beta)$ for prostate was $0.66386(p=0.0031)$, when this was divided by the smallest significant $\beta(0.26165)$, this yielded 2.5372 . When rounded to the nearest integer, or to the nearest integer +0.5 , this became 2.5 . This was then multiplied by 2 to give a partial score of 5 (whole number). Similarly, $\beta$ for lung was $0.74021(p<0.0001)$, when this was divided by 0.26165 , this yielded 2.82901 . On rounding, this became 3.0. Again, this was multiplied by 2 to give a partial score of 6 (whole number). The p-values for fatigue score $1-3$, appetite scores of $1-3$ and $4-7$ were $>0.1$, therefore the partial scores for these subgroups were assigned zero.

Our univariate analysis showed that the survival rate at 6 months was at $30 \%$ (standard error $=5.4 \%$ ) for patients scoring $4-7$ on the shortness of breath scale and $36 \%$ (standard error $=8.0 \%$ ) for those scoring $8-10$ respectively (table 7 ). This most likely stemmed from the small sample size in the subgroup of $8-10$. The median survival of the 2 subgroups was the same ( 14 weeks). There was no reason to believe that patients in the subgroup $8-10$ survived longer than the counterparts in the subgroup of 4-7. To maintain face validity, we assigned the same partial score of 4 to the subgroup of $8-10$ as to the subgroup of 4-7. 


\section{Performance of the Model}

The discrimination index of the model with the final 6 co-variates was greater than

0.7 (table 12). The calibration is shown in figure 4. The analogous $R^{2}$ of the model was 0.31 .

\section{Risk Group Stratification}

\section{Partial Score Method}

The Survival Prediction Score (SPS) is defined as the sum of the partial scores for primary cancer site, site of metastases, KPS, fatigue, appetite and shortness of breath. The SPS ranged from 0 to 32 . The frequency of the SPS is plotted in figure

5. Three risk groups based on the SPS were modeled. Using the SPS, $133 / 395$ (34\%) patients were classified in Group A when the SPS was 13 or less, 129/395 (33\%) patients were in Group B when the SPS was 14-19, and 133/395 (34\%) patients were in Group C when the SPS was 20 or more. Patients in Group A had a 3-month, 6 -month, and 12 -month survival estimate of $83 \%, 70 \%$, and $51 \%$ respectively; patients in Group B, $67 \%, 41 \%$, and $20 \%$ respectively; and patients in Group C , $36 \%, 18 \%$, and $4 \%$ respectively $(p<0.0001$ ) (table 13 and figure 7 ). Median survival and $95 \%$ confidence interval $(95 \% \mathrm{Cl})$ for each group were: Group A $=53$ weeks ( $38-70$ weeks), Group B $=19$ weeks $(17-26$ weeks $)$, Group C $=8$ weeks $(6-10$ weeks) $(p<0.0001)$.

Examples of using the SPS for specific patients are as follows: the SPS for a patient with breast cancer, bone metastases only, KPS $=70$, fatigue score of 5 , appetite 
score of 4 and shortness of breath score of 3 was: $0+0+0+4+0+2=6$ (Group A). The SPS for a patient with prostate cancer, bone metastases only, KPS $=40$, fatigue score of 9 , appetite score of 6 and shortness of breath score of 2 was: $5+0$ $+6+5+0+2=18$ (Group B). Another patient with lung cancer, both bone and visceral metastases, KPS $=30$, fatigue score of 10 , appetite score of 9 and shortness of breath score of 9 , had a SPS of $6+6+6+5+4+4=31$ (Group C) (table 13).

Figure 6 demonstrates that patients classified in the three risk groups had a very different survival experience. It also shows the goodness of fit between the estimated survival curves from Cox's model and the actual outcome estimated by the Kaplan and Meier method.

\section{Number of Risk Factors Method}

The three groups were also stratified based on the total number of risk factors that patients possessed. For those co-variates with more than 2 subgroups, only those subgroups with a $p$ value $<0.1$ were classified as risk factors (table 11). They included:

a) prostate, lung, and others for the primary cancer site;

b) the subgroups of $4-7$ and $8-10$ for the fatigue;

c) the subgroup of $8-10$ for the appetite; 
d) the subgroups of $1-3$ and $4-7$ for shortness of breath. To maintain face validity for reasons mentioned earlier, the subgroup of 8-10 was classified as a risk factor too.

The 6 risk factors were (1) non breast cancer patients, (2) patients with metastases in sites other than bone only, (3) KPS $\leq 50$, (4) fatigue score $\geq 4$, (5) appetite score of $\geq 8$ and (6) shortness of breath $\geq 1$. The frequency distribution for total number of risk factors possessed by patients is listed in figure 7 .

With this procedure, $98 / 395$ (25\%) patients were classified in Group I when they had 3 or less risk factors, $117 / 395$ (30\%) patients were in Group II when they had 4 risk factors, and 180/395 (46\%) patients with 5 to 6 risk factors were in Group III. Patients in Group I had a 3, 6, and 12 month survival of $85 \%, 72 \%$, and $52 \%$ respectively; patients in Group II, $68 \%, 47 \%$, and $24 \%$ respectively; and patients in Group III, 46\%, 24\%, and $11 \%$ respectively ( $p<0.0001$ ) (table 14 and figure 8 ). Median survival and $95 \%$ confidence interval $(95 \% \mathrm{Cl})$ for each group were: Group I $=62$ weeks $(41-70$ weeks), Group II = 24 weeks $(18-29$ weeks), and Group III = 11 weeks $(9-14$ weeks) $(p<0.0001)$ (table 14).

Examples of using the number of risk factors for the same set of patients are as follows: the number of risk factors for a breast cancer patient with bone only metastases, KPS $=70$, fatigue score of 5 , appetite score of 4 and shortness of breath score of 3 was 2 (Group I). The number of risk factors for the prostate cancer 
patient with bone only metastases, KPS $=40$, fatigue score of 9 , appetite score of 6 and shortness of breath score of 2 was 4 (Group II). Similarly, the patient with lung cancer, both bone and visceral metastases, KPS $=30$, fatigue score of 10 , appetite score of 9 and shortness of breath score of 9 had 6 risk factors (Group III) (table 14).

\section{Prognostic Index/ Nomogram Method}

From the six significant co-variates in the final model, KPS ( $>50$ vs $\leq 50$ ); primary cancer site (breast, prostate, lung, others), site of metastases (bone only vs others), appetite score $(0,1-3,4-7,8-10)$, fatigue score $(0,1-3,4-7,8-10)$, and shortness of breath score $(0,1-3,4-7,8-10)$, there were 1024 possible combinations for PI (i.e. 2 $\times 4 \times 2 \times 4 \times 4 \times 4$ ). The predicted survival probabilities at 3,6 , and 12 months of the possible 1024 scenarios are listed in appendix 4. Three selected examples are shown in table 15. Again, for the breast cancer patient (bone only metastases, KPS $=70$, fatigue score of 5 , appetite score of 4 and shortness of breath score of 3 ) (i.e. scenario 42), her survival probabilities at 3, 6, and 12 months were $90 \%(95 \% \mathrm{Cl}, 85$ $-94 \%), 81 \%(73-89 \%)$, and $66 \%(55-79 \%)$ respectively with a median survival of 93 weeks. For the prostate cancer patient (bone only metastases, KPS $=40$, fatigue score of 9 , appetite score of 6 and shortness of breath score of 2 ) (i.e. scenario 686$)$, his survival probabilities were $60 \%(46-79 \%), 37 \%(23-62 \%)$, and $15 \%(6-40 \%)$ respectively with a median survival of 18 weeks $(95 \% \mathrm{Cl} ; 9-27$ weeks). Similarly for the lung cancer patient (both bone and visceral metastases, KPS $=30$, fatigue score of 10 , appetite score of 9 and shortness of breath score of 
9) (i.e. scenario 896$)$, the survival probabilities were $13 \%(5-33 \%), 2 \%(0-11 \%)$, and $0 \%(0-2 \%)$ respectively with a median survival of 5 weeks $(95 \% \mathrm{Cl} ; 3-7$ weeks). 
Many treatment goals and decisions are dependent on how advanced the cancer is. For patients presenting with the early stages of cancer, treatment is aimed at cure, remission, or control of the disease. As the illness progresses and the patient's condition deteriorates, the burden of treatments may begin to outweigh their benefits. Others may present with metastatic disease at initial diagnosis. When cure or remission is not possible, treatment goals may change appropriately from prolonging life to controlling symptoms and improving the quality of life. The transition from traditional to palliative care can be very difficult in caring for patients with advanced cancer. The determination of the prognosis and life expectancy is critical to the discussion of care for patients with terminal disease.

It is difficult to determine prognoses, as patients with advanced cancer may develop an acute illness (e.g. pulmonary embolus, sepsis) resulting in unexpected death. On the other hand, studies have shown that most patients who enroll in a hospice do so late in the course of their disease, when they may not benefit from all the services the hospice has to offer $(5,6,68,69)$. Moreover, a shortened length of stay in a hospice has been associated with increased suicidal ideation experienced by patients (70), as well as more difficult bereavement for caregivers (71). These studies emphasize the importance of continued research in this area to predict survival more accurately in patients near the end of life. 
To date, assessing life expectancy for patients with advanced cancer has been relatively inaccurate. Studies have attempted to identify specific prognostic factors for patients near the end of life. However, most of them are small retrospective studies and suffer from statistical flaws. We attempted to analyze the potential prognostic factors collected prospectively in this group of patients with sound statistical methodology.

\section{Statistical vs Judgemental Approaches}

The selection of multiple potential prognostic factors for a prognostic model and the approach to reducing them to a manageable and feasible number can be dictated by empirical data or based on clinical judgement. These are called respectively the statistical and the judgemental approaches.

The statistical approach uses large databases to identify co-variates which are corelated with an outcome of interest. Although these statistical approaches are mostly empirically based, they all include some elements of judgment. Overt judgements are eliminated by the statistical process but subtle judgements are imbedded in the process.

The judgemental approach is used either when no empirical data are available; when the goal is to develop a measure of a clinical concept such as disease activity or disease severity where there is no gold standard; or when by the time the data 
are collected the clinical environment may have changed to the point that any prediction derived from these data may be outmoded.

Methods of choosing and weighing candidate items to describe a clinical judgement include tradition, conventional wisdom, personal experience or consensus as a guide to what is important. Both the Apgar score $(72,73)$ and the Glasgow Coma Scale $(74,75)$ are 2 examples of the judgemental approach. In 1953, Virginia Apgar proposed the Apgar Score as a means of evaluating the physical condition of infants shortly after delivery. Each of the five easily identifiable characteristics - heart rate, respiratory effort, muscle tone, reflex irritability, and colour - was assessed and assigned a value of $0-2$. The total score is the sum of the five components (72). The Glasgow Coma Scale was developed by Teasdale and Jennett. It is composed of independent observations of three aspects of behavior: eye opening (on a scale of $1-4)$, the best motor responsiveness $(1-6)$, and the best verbal responsiveness ( 1 - 5), which, when summed, yield an overall numerical rating between 3 and 15 (74, 75).

Since the clinicians' estimate of survival of patients with metastatic cancer is often incorrect and there has been only one article from the radiation oncology setting to guide the judgemental approach, we preferred to employ the statistical approach in our model. 


\section{Choice of Measurement Tool}

The Edmonton Symptom Assessment Scale (ESAS) was designed by Bruera and associates. It consists of nine $100 \mathrm{~mm}$ visual analog scales (VAS) for pain, activity, nausea, depression, anxiety, drowsiness, appetite, sense of well being and shortness of breath $(0=$ lack of symptom, $100=$ worst possible symptom $)$. It is a simple and useful method for the assessment of patients receiving palliative care, and can be applied repeatedly to a very ill population (76). The ESAS was slightly modified by Philip et al for the Australian population in their longitudinal study (77). The variable 'weakness' was substituted for 'activity' as performance status was reported regularly, and a measurement of pain relief was added. These authors concluded that the modified ESAS had satisfactory face, construct and criterion validity as well as repeatability when compared with both the Rotterdam Symptom Checklist and the Brief Pain Inventory (BPI).

Chang and associates noted that the ESAS distress score correlated most closely with the physical symptom subscales of the Functional Assessment of Cancer Therapy (FACT) and the Memorial Symptom Assessment Scale (MSAS) as well as with KPS (78). The ESAS individual item and summary scores showed good internal consistency and correlated appropriately with corresponding measures from the FACT and MSAS instruments. Individual items between the instruments correlated well. Pain ratings in the ESAS, MSAS, and FACT correlated best with the "worstpain" item of the Brief Pain Inventory (BPI). These authors confirmed that ESAS was a valid instrument. 
Paice and Cohen examined the validity of a verbally administered $0-10$ numeric (pain intensity) rating scale with the VAS using convergence methods. The correlation between the two was strong and statistically significant $(r=0.847, p<$ 0.001 ), supporting the validity of the former. They concluded that the verbally administered 0 - 10 numeric rating scale provides a useful alternative to the VAS, particularly as more contact with patients is established via telephone (79).

We have therefore further modified the ESAS to an 11-point categorical scale (0-10, $0=$ lack of symptom, $10=$ worst possible symptom) to facilitate a subsequent telephone follow-up. Since the ESAS has been used extensively as a measurement tool in palliative care services, our use of the modified ESAS allows us to compare symptoms of patients across studies.

\section{Choice of Co-Variates in Item Generation}

Performance status, and symptoms comprising part of the 'terminal cancer syndrome' as identified by Reuben et al (10) were most predictive of survival in the literature. We have therefore included weight loss, KPS, and the symptoms in the ESAS in the item generation phase of our study. The usual cut-off for weight loss in the literature is $10 \%$ over the last 6 months. Since the majority of our patients were referred for palliation of bone pain, we included both the severity of pain and analgesic consumption as potential prognostic factors. 
Initially high KPS scores do not necessarily result in longer survival because scores frequently drop precipitously. In contrast, very low scores $(10-20)$ are associated with death within 3 months. Most of our patients were ambulatory. In view of the KPS distribution in our study population, we have arbitrarily divided our patients into KPS $\leq 50$ (KPS $50=$ requiring considerable assistance from others and frequent medical care) and KPS $>50$ (KPS $60=$ requiring occasional assistance from others but able to care for most needs).

From clinical experience in the clinic, patients with breast and prostate cancers survive longer in general when compared with those suffering from lung cancer; and patients with bone only metastases live longer than patients with visceral metastases. These observations explain the rationale for including the primary cancer site and site of metastasis in the univariate analysis. Primary cancer site was further categorized into 4 subgroups because patients with primaries of lung, breast, and prostate comprised the majority of the referrals.

The duration between first diagnosis of cancer and diagnosis of metastatic disease may reflect the aggressiveness of the disease. The time of first diagnosis of cancer could be accurately obtained from the pathology report or from the history. Since it was difficult to ascertain the date of diagnosis of first metastasis, we chose the time from first diagnosis of cancer to first consultation in the palliative radiotherapy clinic as a 'surrogate'. Based on the distribution of such time, we chose 12 months as the cut-off. 
The age of the patient may influence not only our recommendation of the treatment options, but also our prediction of their remaining lifespan. Since increasing age is probably not associated with decreased survival in a hospice setting (15), categorizing age into several subgroups is not necessary.

It is not common practice to perform routine blood work in patients attending outpatient palliative radiotherapy clinics. We have not included any biochemical nor molecular markers in our prospective database. Moreover, the clinicians' prediction is often incorrect in the optimistic direction. Furthermore, the prediction of the clinician is likely to depend on experience and training and is poorly reproducible, and therefore we did not include this variable.

\section{Difference in Median Survival and KPS}

Since most of the studies which used prognostic factors to predict survival were performed in hospices and palliative care programs, the reported median survival was usually no longer than 12 weeks (15). To date, one of the better palliative prognostic predictions for the staging of terminally ill cancer patients was developed by a group of Italian clinicians. They employed a training set of 519 patients, with subsequent successful validation in their testing set of 451 patients, to develop their model. The median survival of the 2 sets of patients was 32 and 33 days respectively. They therefore reported the results with reference to 30 -day survival probability $(35,40)$. 
Patients attending out-patient palliative radiotherapy clinics represent a less advanced group when compared with those in hospices. The median survival of our 395 patients was 136 days ( 19.4 weeks). Grabowski et al reported a median survival of 4 months in 97 patients who underwent radiation treatment for metastatic cancers. Because of the longer median survival, they reported the prognostic predictors at $2,4,8$, and 16 months (29). In the present study we have chosen to evaluate survival at 3,6 and 12 months.

Karnofsky Performance Status has been regarded as the most important predictor for survival. Patients attending the palliative radiotherapy clinics had better KPS scores when compared with those in the hospices (table 16). One therefore needs to exercise caution in comparing the patient populations and extrapolating the prognostic predictors from hospice settings to out-patient palliative radiotherapy clinics or vice versa.

\section{Prognostic Factors}

We identified primary cancer site, site of metastases, KPS, fatigue, appetite, and shortness of breath as significant prognostic factors in the model generated from multivariate regression analysis. In previous studies of patients in their last months of survival, the site of the primary and extent of metastatic disease were predictive of survival in only 2 of 19 studies $(29,32)$. Most studies of advanced terminally ill cancer patients such as in hospice facilities suggest the survival of those patients is 
not significantly correlated to primary cancer site, initial extent of disease at presentation, and current sites of metastases. Patients attending radiotherapy clinics are mostly ambulatory, representing a less advanced group of patients.

Performance status has shown the best correlation with the length of survival in the literature $(7,10,16,19,20,25-27,29,31,33-35)$. Symptoms comprising part of the 'terminal cancer syndrome' identified by Reuben et al were strong predictors of poor survival, including appetite and shortness of breath (10). The significant predictors in our model were consistent with the above observation and also in keeping with those identified in the systematic review by Vigano et al (table 17) (15). Weight loss, however, was not statistically significant in our multivariate analysis, although the appetite score 8 - 10 was a significant predictor.

Llobera and colleagues identified the presence of asthenia as a major predictor of short survival (80). Asthenia is a Greek word meaning without strength. It has been defined as 'profound tiredness occurring after usual or minimal effort, accompanied by an unpleasant anticipatory sensation of generalized weakness'. It is a devastating symptom for which few effective treatments exist (81). Vigano et al reported anorexia and fatigue to be the symptoms given the highest scores for distress among terminal cancer patients. Anorexia, asthenia, and weight loss are the hallmark of cancer cachexia (82). In our population, fatigue, appetite, and poor sense of well-being received the highest scores for the symptom distress using the 
modified ESAS (table 6). Fatigue was an independent predictor of survival in our model.

Based on the final model, we generated 3 risk groups with different levels of survival using 3 different methods: (1) partial score method, (2) number of risk factors method, and (3) prognostic index /nomogram method. The first and third methods took into account the different prognostic weightings whereas the second assumed equal weighting among the 6 prognostic factors. However, the nomogram requires a table and/or calculator, and is less appealing to daily practice. The former 2 methods can be condensed in pocket-size tables for easy reference (tables 18 and 19). The nomogram permits the assignment of a survival probability to each case without calculation. Alternatively the normogram results can be readily retrieved in a palm pilot program. Nevertheless, the partial score method is preferable because of its inclusion of the prognostic weightings of the predictors and easy applicability.

\section{Potential Limitations}

Our study has several limitations. We have not included all of our patients in the year 1999. The model was developed from mentally competent English speaking patients. There may be potential important prognostic factors that have been omitted in the item generation phase of our study. Our dichotomizing some co-variates and categorizing the others into subgroups may not identify the cutoffs with the best discriminating capacity. As mentioned earlier, the sample size was small for the subgroup of patients with shortness of breath scores of $8-10$. 
Coates and associates reported that the global scale and the scales of physical, role, emotional, cognitive and social function in the European Organization for Research and Treatment of Cancer (EORTC) QLQ-C30 Quality of Life (QL) Scores were each significantly predictive of subsequent survival duration in univariate analyses. Single-item QL scores for overall physical condition and overall quality of life, and the global and social functioning scales remained independently prognostic after allowing for performance status and age, and, among solid tumor patients, metastatic site (83).

The prognostic value of patient-rated performance status has been assessed (84 87). Loprinzi et al asked 1115 patients with advanced lung or colorectal cancer to rate their KPS and the Eastern Cooperative Oncology Group (ECOG) performance status and answer questions about their nutritional status before receiving chemotherapy (84). Physicians also rated the patients' performance status. In a Cox multivariate analysis, both the physician-judged and patient-judged performance status were independent significant predictors of survival. Physicians tended to give a higher rating of performance status than did the patients themselves. In addition, patient's own rating on nutritional factors such as appetite and food intake was a significant independent predictor for survival.

Some investigators have reported that non-clinical attributes of patients, such as religion $(88,89)$ and social support $(90)$, affect survival of patients. Cancer patients 
suffer from a number of psychosocial problems related to the progression of their disease as well as medical interventions. Anxiety and depression are very common problems among them. Psychotherapy, both group and individual, has been shown to be effective in improving quality of life, and in some cases, there is evidence of extended survival time $(91-93)$. Moreover, Phillips and King studied whether persons were able to prolong life until they had reached a symbolically meaningful event. They showed that Jewish mortality fell sharply below the expected level just before Passover and rose by an equal amount above expected immediately afterwards. In contrast, non-Jewish control groups showed no significant fluctuation of mortality around Passover. They concluded that some Jews were briefly able to prolong life until after the Jewish holiday. They suggested that symbolic meaningful events in the patient's life and culture may have a pronounced short-term impact on mortality (94). Others have found that psychosocial factors are not associated with survival in terminally ill hospice patients $(10,95)$.

\section{Future Work}

The final model based on simple clinical co-variates proved to be statistically significant in a multivariate analysis. It does not require any invasive investigations including blood sampling, or any assistance from experienced physicians. The present study stresses the importance of patient's subjective symptoms. Three approaches were employed in risk group stratification. The model appears promising in this population (training set). Although the calibration and discrimination of our predictive model from the training set was satisfactory, the 
analogous $R^{2}$ was 0.31 . Most of the investigators do not report the $R^{2}$ result of their predictive model in the literature, therefore it is difficult to interpret the actual correlation of the analogous $\mathrm{R}^{2}$ with the predictive ability of the model in the subsequent validation sets. Personal communication with statistician colleagues indicates that most of the predictive models reported in the literature have $R^{2}$ less than 0.4. Nevertheless, our current models from the training set will need to be validated in an independent series (testing test). Work is in progress to validate the model in the prospective database of year 2000 . If the model is successfully validated in the testing test, it needs to be externally validated in similar settings in other cancer centres. Other future projects would include the comparison of predictive ability between the partial score method and number of risk factor methods, and comparison of the current model with that derived from recursive partitioning.

\section{Potential Use of the Validated Model}

The model would facilitate the decision to shift from cure to care and the subsequent enrollment of the patient in a hospice program (for example, patients in Groups $C$ or III would be most eligible for hospice admissions). Counselling with the patients and families on expected survival can be guided by the model. This would help the patients to have realistic expectations to guide their planning of end-of life issues and treatment expectations. 
Patients could be classified into prognostically homogeneous subgroups for clinical trials, thereby ensuring that important prognostic factors are well balanced between treatment groups. Patients with advanced solid tumors may be included in phase I clinical trials. In such studies, the benefit expected is generally lower than the likelihood of toxicity and may even be non-existent if the patient's life expectancy is too short. It would thus be of crucial importance to select patients for phase I studies that have a fair chance of somewhat longer survival and adequate tolerance in order to assess longer term toxicity $(96,97)$. Patients in Groups $C$ or III have less than three months of life expectancy and, as they would not be assessable for the toxicity, they should not be treated in a phase I clinical trial. In contrast, patients in Groups A or I would have a life expectancy of more than six months and might experience the therapeutic benefit of a phase I clinical trial, whatever the possible toxicity.

The same consideration applies to the radiotherapy trials of bone metastases. Price et al reported a prospective randomized trial of single and multifraction radiotherapy schedules in the treatment of painful bony metastases. Compliance with the follow up was limited due to early death of the patients. Thirty percent of the study patients died within three months of randomization (52). This threatened the validity of the study conclusion. Patients in Groups C or III with median survivals of 8 and 11 weeks respectively may not be ideal candidates for future bone metastases trials. 
Palliative radiation therapy plays a crucial role in maintaining quality of life for many advanced cancer patients. For those predicted to have brief survival (e.g. patients in Groups $\mathrm{C}$ or (II), protracted radiation schedules are a burden for the patient notwithstanding the health economic issues this raises (98). Patients in this category might be more appropriately treated with single fractionation for bone metastases, and perhaps with steroid and supportive care only in patients with brain metastases in view of the questionable effectiveness of whole brain radiotherapy in patients with brief survival. Certain groups of patients may be expected to have prolonged survival. Patients in Groups A or I would be examples. In these cases, the use of more conventional fraction size and longer overall treatment time may be warranted (99), considering the potential long-term morbidity associated with a rapid fractionation scheme (29).

\section{Application of the Future Validated Model}

Research aimed at identifying prognostic factors of survival in advanced cancer patients is not only delicate but also risky. The probabilistic nature of the model acquired has to be emphasized and the use of the model requires great caution in the individual case. The survival prediction can be given only in terms of a probability (100).

The model should not delay patient access to palliative and supportive care services at an early phase in the illness when such intervention would be appropriate in meeting patient / families expectations and needs. 
Guidelines have been suggested for evaluation of the methods used and of the findings from the studies on the prognostic factors. Readers should ask the following questions before they apply the model to their practice (101):

1. Epidemiological validity
a) whether the sample of patients was representative and well-defined at a similar point in the course of the disease
b) whether follow-up was sufficiently long and complete
c) whether the outcome criteria used were objective and unbiased
d) whether there was adjustment for important prognostic factors

2. Biostatistical consistency
a) the likelihood of the outcome event(s) in a specific period of time
b) the precision of the estimates of the likelihood

3. Clinical applicability
a) whether the study patients were similar to one's own
b) whether the results will lead directly to selecting or avoiding therapy
c) whether the results are useful for reassuring or counselling patients

Studies involving multiple centers may offer the best chance of developing an accurate predictive model for survival in palliative setting (13). Future research should focus on KPS, terminal cancer syndrome, and should perhaps incorporate psychosocial correlates while avoiding routine blood work. A bedside model, the Apgar Score, has been established for prognostic determination of beginning of life 
(72). A similar system applied judiciously would be of equal value at life's end and may assist in dealing with the difficult question of "how long do I have to live?" (31). 
Table 1

Studies of Clinicians' Prognostic Accuracy

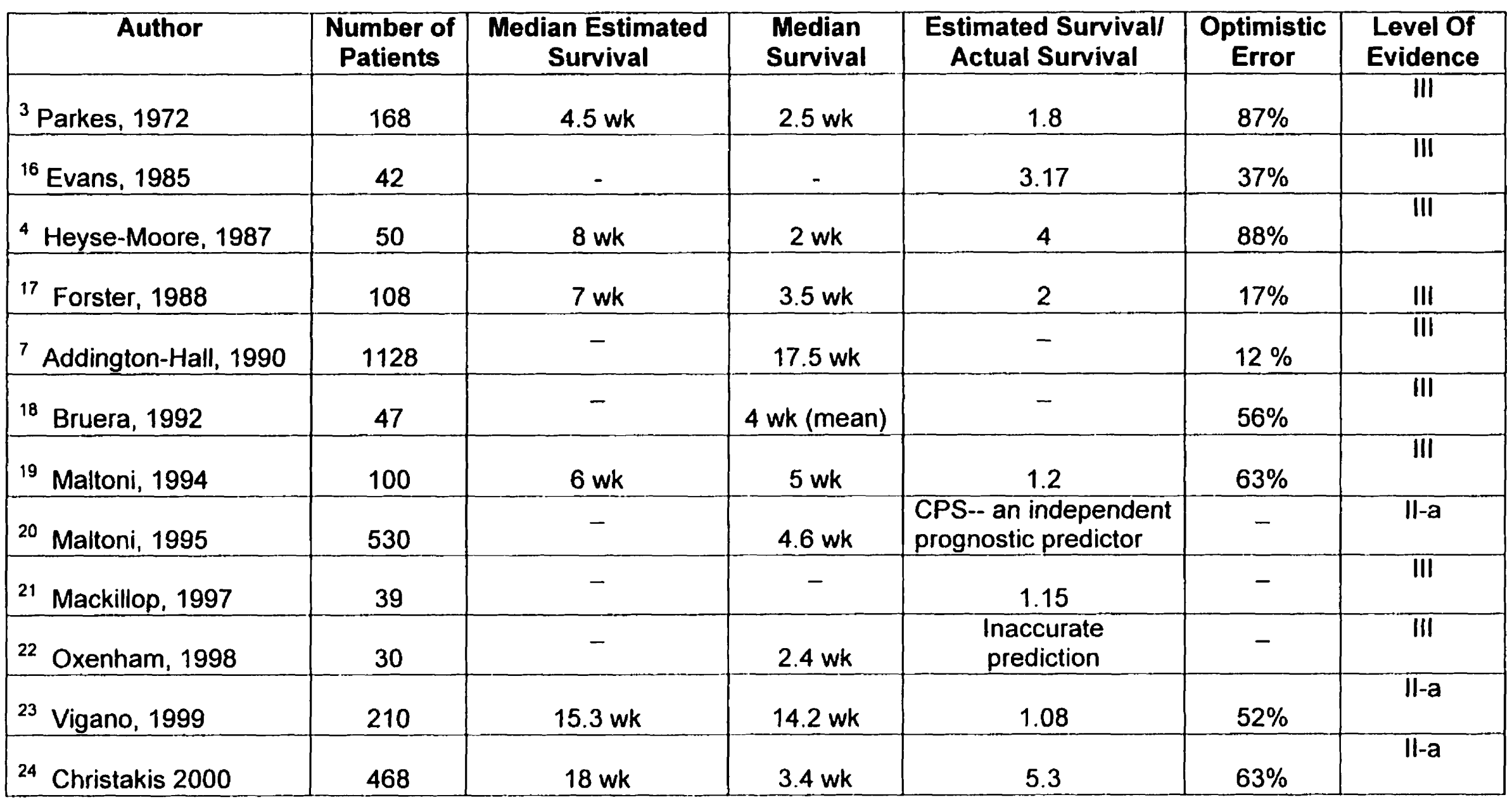

CPS - Clinician's Prediction of Survival

The definition of optimistic error varied from studies to studies 
Table 2

Analysis of Literature on Prognostic Indicators of Survival

\begin{tabular}{|c|c|c|c|}
\hline Author & $\begin{array}{c}\text { Number of } \\
\text { Variables tested } \\
\text { in univariate } \\
\text { analysis }\end{array}$ & $\begin{array}{c}\text { Prospective } \\
\text { Validation }\end{array}$ & Level of Evidence \\
\hline${ }^{25}$ Yates, 1980 & N/A & N/A & III \\
\hline${ }^{26}$ Mor, 1983 & N/A & N/A & III \\
\hline${ }^{16}$ Evans, 1985 & N/A & N/A & III \\
\hline${ }^{10}$ Reuben, 1988 & 15 & $\mathrm{~N}$ & III \\
\hline $\begin{array}{c}\text { 'Addington-Hall, } \\
\text { 1990 }\end{array}$ & N/A & $\mathrm{N}$ & III \\
\hline $\begin{array}{c}{ }^{2 /} \text { Schonwetter, } \\
1990\end{array}$ & N/A & $\mathrm{N}$ & III \\
\hline${ }^{28}$ Ventafridda, \\
1990
\end{tabular}

N/A- not available

Y-Yes $N$-no

b - subsequently validated in other studies

c - subsequently validated in later series

$d$ - both training and testing sets described in the paper 
Table 3

Prognostic Indicators of Survival

\begin{tabular}{|c|c|c|}
\hline Author & $\begin{array}{l}\text { Number of } \\
\text { Patients }\end{array}$ & Prognostic Factors \\
\hline 25 Yates, 1980 & 104 & $\begin{array}{l}\text { Low KPS scores accurately predicted early death but high initial KPS scores did not necessarily predict long } \\
\text { survival. }\end{array}$ \\
\hline Mor, 1983 & 685 & Direct relationship between KPS and survival \\
\hline T6 Evans, 1985 & 42 & KPS correlated better with actual survival than did the clinical predictions \\
\hline To Reuben, 1988 & 1592 & KPS, dry mouth, shortness of breath, problems eating, recent weight loss, and trouble swallowing \\
\hline 7 Addington-Hall, 1990 & 230 & $\begin{array}{l}\text { Spitzer Quality of Life Index Score - patients with a low score were more likely to die within } 6 \text { months than those } \\
\text { with higher scores, but scores on the Index were not strong predictors of } 6 \text { month survival in individual patients. }\end{array}$ \\
\hline 27 Schonwetter, 1990 & 172 & Dressing ability, pulse rate, level of appetite, and transferring ability. \\
\hline Ventafridda, 1990 & 120 & Appearance of unendurable symptoms and aggravation of previously controllable symptoms. \\
\hline Bruera, 1992 & 47 & Dysphagia, cognitive failure, and weight loss \\
\hline Grabowski, 1992 & 97 & KPS, site of primary disease, and solitary site of metastases. \\
\hline Tsamandouraki, 1992 & 202 & Home care less effective compared to hospital care \\
\hline 31 Rosenthal, 1993 & 148 & $\begin{array}{l}\text { Performance Status, admission at first referral to palliative care service, hyperbilirubinemia }(\geq 19 \mu \mathrm{mol} / \mathrm{L}) \text {, and } \\
\text { hypotension (systolic blood pressure }<90 \mathrm{mmHg} \text { ) }\end{array}$ \\
\hline Hardy, 1994 & 107 & In-patient until death, lung primary, intervention, dyspnea, and decubitus ulcers \\
\hline Maltoni, 1994 & 100 & KPS \\
\hline 33 Allard, 1995 & 1081 & Performance Status \\
\hline Maltoni, 1995 & 530 & Clinical Prediction of Survival, anorexia, dysphagia, palliative steroid treatment, KPS, and hospitalization \\
\hline "Tamburini, 1996 & 115 & Confusion, cognitive status and global health status. \\
\hline Morita, 1999 & 245 & Poor performance status, appetite loss, edema, dyspnea at rest, and delirium. \\
\hline $\begin{array}{l}{ }^{35} \text { Pirovano } 1999 \\
{ }^{40} \text { Maltoni } 1999\end{array}$ & $\begin{array}{l}519 \\
451\end{array}$ & Dyspnea, anorexia, KPS, clinical prediction, total white blood count, and lymphocyte percentage. \\
\hline
\end{tabular}

Ref 35 was the training set and ref 40 was the validation set 


\section{Table 4}

Patient Characteristics in the database $(n=395)$

Gender:

Male

Female

$198(50 \%)$

$197(50 \%)$

Age (Years):

Median

68 years

Range

$31-93$ years

Primary Cancer Site:

Lung

Breast

$143(36 \%)$

Prostate

$80(20 \%)$

Gastrointestinal

$56(14 \%)$

$42(11 \%)$

Unknown

$38(10 \%)$

Others

$36(9 \%)$

Weight Loss:

( $\geq 10 \%$ over the last 6 months)

$132(33 \%)$

Karnofsky Performance Score:

$$
\begin{aligned}
& 10-20 \\
& 30-40 \\
& 50-60 \\
& 70-80 \\
& 90-100
\end{aligned}
$$

$44(11 \%)$

$163(41 \%)$

$167(42 \%)$

$19(5 \%)$

Median

60

Range

$10-100$ 


\section{Table 5}

Comparison of patients included $(n=395)$ and not included $(n=88)$ in the database

Age at First Visit (Years)

$26-35$

$36-45$

$46-55$

$56-65$

$66-75$

$76-85$

$\geq 86$

median

range

Gender

male

female

Primary Cancer Site

Lung

Breast

Prostate

Gastrointestinal

Others

Status

Dead

Alive

Median Survival

Survival Rate at 6 months
Included

Not included

$$
\begin{gathered}
2(1 \%) \\
16(4 \%) \\
41(10 \%) \\
94(24 \%) \\
148(37 \%) \\
87(22 \%) \\
7(2 \%) \\
68
\end{gathered}
$$

$31-93$

$198(50 \%)$

$197(50 \%)$

$143(36 \%)$

$80(20 \%)$

$56(14 \%)$

$42(11 \%)$

$74(19 \%)$

$321(81 \%)$

$74(19 \%)$

19.4 weeks

$43 \%$
P-Value

0.7

$0(0 \%)$

$5(6 \%)$

$14(16 \%)$

$15(17 \%)$

$31(35 \%)$

$19(22 \%)$

$4(5 \%)$

68

$39-90$

$45(51 \%)$

43 (49\%)

0.9

0.6

$29(33 \%)$

$19(22 \%)$

$9(10 \%)$

$9(10 \%)$

$22(25 \%)$

$73(83 \%)$

$15(17 \%)$

15 weeks

$35 \%$ 
Table 6

Symptom Distress according to the

Modified Edmonton Symptom Assessment Scale ( $n=395)$

\section{Median}

Pain

Fatigue

5

Nausea

0

Depression

2

Anxiety

2

Drowsiness

3

Appetite

4

Sense of well-being

4

Shortness of breath

1

$0=$ lack of symptom $10=$ worst possible symptom

Range of 9 symptoms $=0-10$ 
Table 7

Univariate Survival Analysis

\begin{tabular}{|c|c|c|c|c|c|c|c|}
\hline & Co-variates & Subgroups & $\begin{array}{c}\text { Number } \\
\text { of } \\
\text { Patients }\end{array}$ & $\begin{array}{c}\text { Missing } \\
\text { Values } \\
(\%) \\
\end{array}$ & $\begin{array}{c}\begin{array}{c}\text { Survival at } \\
6 \text { months } \\
(\%)\end{array} \\
\end{array}$ & $\begin{array}{l}\text { Median } \\
\text { Survival } \\
\text { (weeks) }\end{array}$ & $\begin{array}{l}\text { a Log-Rank } \\
\text { P-Value }\end{array}$ \\
\hline \multirow{2}{*}{1} & \multirow{2}{*}{ Age at $1^{\text {st }}$ visit } & $\leq 68$ years & 207 & \multirow{2}{*}{$0(0 \%)$} & 47 & 21 & \multirow{2}{*}{0.18} \\
\hline & & $>68$ years & 188 & & 39 & 19 & \\
\hline \multirow{4}{*}{2} & Primary Cancer & Lung & 143 & \multirow{4}{*}{$0(0 \%)$} & 34 & 16 & \multirow{4}{*}{$<0.0001$} \\
\hline & Site & Breast & 80 & & 65 & 52 & \\
\hline & & $\begin{array}{l}\text { Prostate } \\
\end{array}$ & 56 & & 60 & 39 & \\
\hline & & Others & 116 & & 31 & 14 & \\
\hline \multirow[t]{2}{*}{3} & Site of & bone only & 113 & \multirow{2}{*}{$0(0 \%)$} & 55 & 29 & \multirow{2}{*}{$<0.0001$} \\
\hline & & others & 282 & & 38 & 16 & \\
\hline \multirow{2}{*}{4} & \multirow{2}{*}{$\begin{array}{c}\text { Weight loss ( } \geq \\
10 \% \text { over last } 6 \\
\text { months) }\end{array}$} & Yes & 132 & \multirow{2}{*}{$0(0 \%)$} & 30 & 14 & \multirow{2}{*}{$<0.0001$} \\
\hline & & No & 263 & & 49 & 26 & \\
\hline \multirow{2}{*}{5} & \multirow{2}{*}{ KPS } & $>50$ & 278 & \multirow{2}{*}{$0(0 \%)$} & 52 & 27 & \multirow{2}{*}{$<0.0001$} \\
\hline & & $\leq 50$ & 117 & & 20 & 8 & \\
\hline \multirow{2}{*}{6} & \multirow{2}{*}{$\begin{array}{l}\text { Time from } 1^{\text {st }} \\
\text { diagnosis of } \\
\text { cancer to } 1^{\text {st }} \\
\text { consultation }\end{array}$} & $>12$ months & 202 & \multirow{2}{*}{$2(0.5 \%)$} & 51 & 26 & \multirow{2}{*}{$<0.0001$} \\
\hline & & $\leq 12$ months & 191 & & 33 & 15 & \\
\hline \multirow{4}{*}{7} & \multirow{4}{*}{$\begin{array}{l}\text { Analgesic } \\
\text { consumption } \\
\text { within last } 24 \\
\text { hours of } 1^{\text {st }} \\
\text { consultation }\end{array}$} & none & 102 & \multirow{4}{*}{$0(0 \%)$} & 53 & 30 & \multirow{4}{*}{0.25} \\
\hline & & non-opioids & 44 & & 36 & 19 & \\
\hline & & weak opioids & 54 & & 50 & 26 & \\
\hline & & strong opioids & 195 & & 37 & 17 & \\
\hline \multirow{4}{*}{8} & \multirow{4}{*}{ Pain } & 0 & 87 & & 45 & 20 & \\
\hline & & $1-3$ & 126 & $22(60)$ & 49 & 25 & 01 \\
\hline & & $4-7$ & 111 & $22(0 \%)$ & 34 & 16 & 0.1 \\
\hline & & $8-10$ & 49 & & 47 & 21 & \\
\hline & & 0 & 26 & & 64 & 63 & \\
\hline 9 & Fatique & $1-3$ & 87 & $34(9 \%)$ & 60 & 35 & $<0.0001$ \\
\hline & & $4-7$ & 165 & $34(9 \%)$ & 39 & 19 & \\
\hline & & $8-10$ & 83 & & 32 & 13 & \\
\hline & & 0 & 200 & & 48 & 24 & \\
\hline 10 & Nausea & $1-3$ & 111 & $27(7 \%)$ & 44 & 19 & 0.0004 \\
\hline 10 & Nausea & $4-7$ & 41 & $27(1 \%)$ & 37 & 19 & 0.0004 \\
\hline & & $8-10$ & 16 & & 6 & 10 & \\
\hline & & 0 & 92 & & 49 & 24 & \\
\hline 11 & & $1-3$ & 149 & $53(13 \%)$ & 49 & 25 & 0.004 \\
\hline & Uepression & $4-7$ & 82 & $53(13 \%)$ & 41 & 20 & \\
\hline & & $8-10$ & 19 & & 16 & 8 & \\
\hline
\end{tabular}


Table 7

Univariate Survival Analysis

\begin{tabular}{|c|c|c|c|c|c|c|c|}
\hline & Co-variates & Subgroups & $\begin{array}{c}\text { Number } \\
\text { of } \\
\text { Patients }\end{array}$ & $\begin{array}{c}\text { Missing } \\
\text { Values } \\
(\%)\end{array}$ & $\begin{array}{c}\text { Survival at } \\
6 \text { months } \\
(\%)\end{array}$ & $\begin{array}{l}\text { Median } \\
\text { Survival } \\
\text { (weeks) }\end{array}$ & $\begin{array}{l}\text { a Log-Rank } \\
\text { P-Value }\end{array}$ \\
\hline \multirow{4}{*}{12} & \multirow{4}{*}{ Anxiety } & 0 & 72 & \multirow{4}{*}{$52(13 \%)$} & 50 & 24 & \multirow{4}{*}{0.5} \\
\hline & & $1-3$ & 143 & & 46 & 19 & \\
\hline & & $4-7$ & 95 & & 41 & 19 & \\
\hline & & $8-10$ & 33 & & 40 & 16 & \\
\hline \multirow{4}{*}{13} & \multirow{4}{*}{ Drowsiness } & 0 & 71 & \multirow{4}{*}{$36(9 \%)$} & 64 & 36 & \multirow{4}{*}{$<0.0001$} \\
\hline & & $1-3$ & 137 & & 50 & 24 & \\
\hline & & $4-7$ & 112 & & 33 & 17 & \\
\hline & & $8-10$ & 39 & & 18 & 8 & \\
\hline \multirow{4}{*}{14} & \multirow{4}{*}{ Appetite } & 0 & 73 & \multirow{4}{*}{$29(7 \%)$} & 54 & 33 & \multirow{4}{*}{$<0.0001$} \\
\hline & & $1-3$ & 102 & & 50 & 24 & \\
\hline & & $4-7$ & 128 & & 45 & 18 & \\
\hline & & $8-10$ & 63 & & 19 & 11 & \\
\hline \multirow{4}{*}{15} & \multirow{4}{*}{$\begin{array}{l}\text { Sense of well- } \\
\text { being }\end{array}$} & 0 & 16 & \multirow{4}{*}{$58(15 \%)$} & 69 & 56 & \multirow{4}{*}{$<0.0001$} \\
\hline & & $1-3$ & 130 & & 52 & 27 & \\
\hline & & $4-7$ & 151 & & 39 & 18 & \\
\hline & & $8-10$ & 40 & & 29 & 14 & \\
\hline \multirow{4}{*}{16} & \multirow{4}{*}{$\begin{array}{c}\text { Shortness of } \\
\text { breath }\end{array}$} & 0 & 131 & \multirow{4}{*}{$28(7 \%)$} & 58 & 34 & \multirow{4}{*}{$<0.0001$} \\
\hline & & $1-3$ & 126 & & 39 & 18 & \\
\hline & & $4-7$ & 74 & & 30 & 14 & \\
\hline & & $8-10$ & 36 & & 36 & 14 & \\
\hline
\end{tabular}

a-(method 1)-replacing the missing value with the median of that co-variate. 
Table 8

Log-Rank P-Value for the inclusion of the missing data in the Univariate Survival Analyses using different methods

\begin{tabular}{|l|l|l|l|l|}
\hline Co-variates & Method 1 & Method 2 & Method 3 & Method 4 \\
\hline $\begin{array}{l}\text { Time from } 1^{\text {st }} \text { diagnosis of cancer to } \\
1^{\text {st }} \text { consultation }\end{array}$ & $<0.0001$ & 0.0001 & 0.0003 & $<0.0001$ \\
\hline Pain & 0.1 & 0.07 & 0.02 & 0.1 \\
\hline Fatigue & $<0.0001$ & $<0.0001$ & $<0.0001$ & 0.0001 \\
\hline Nausea & 0.0004 & 0.0002 & 0.0002 & 0.04 \\
\hline Depression & 0.004 & 0.001 & 0.0004 & 0.007 \\
\hline Anxiety & 0.5 & 0.4 & 0.5 & 0.3 \\
\hline Drowsiness & $<0.0001$ & $<0.0001$ & $<0.0001$ & $<0.0001$ \\
\hline Appetite & $<0.0001$ & $<0.0001$ & $<0.0001$ & $<0.0001$ \\
\hline Sense of well-being & $<0.0001$ & $<0.0001$ & $<0.0001$ & $<0.0001$ \\
\hline Shortness of breath & $<0.0001$ & $<0.0001$ & $<0.0001$ & $<0.0001$ \\
\hline
\end{tabular}

Method 1: replacing the missing data with the median

Method 2: discarding the missing data

Method 3: matching other co-variates and replacing the missing data with the mode

Method 4: replacing the missing data with a random number 


\section{Table 9}

Total number of degrees of freedom from entry of the 12 co-variates into the regression model

Co-Variates

Primary Cancer Site

Site of Metastases

Weight Loss

KPS

Time from $1^{\text {st }}$ diagnosis of cancer to $1^{\text {st }}$ consultation in clinic

Fatigue

Nausea

Depression

Drowsiness

Appetite

Sense of well-being

Shortness of breath

\section{Degrees of Freedom}

3

1

1

1

1

3

3

3

3

3

3

3

28

Total of 12 Co-Variates

For example, the number of degrees of freedom for the co-variate fatigue (subdivided into 4 subgroups: $0,1-3,4-7$, and 8-10) is 3. According to Harrell's 10:1 rule of thumb, the maximum allowed degrees of freedoms for 321 deaths is 32 . 
Table 10

Co-variates that were retained in the multivariate analysis as prognostic for survival with their p-values and hazard ratios

PRIMARY CANCER SITE

BREAST

PROSTATE

LUNG

OTHERS

SITE OF METASTASES

BONE METASTASES ONLY

OTHERS

KPS

$>50$

$\leq 50$

ESAS FATIGUE SCORE

0

$1-3$

4-7

8-10

ESAS APPETITE SCORE

0

1-3

4-7

8-10

P-Value Hazard ratio $(95 \% \mathrm{Cl})$

$<0.0001$

1.00
$1.94(1.25-3.01)$
$2.10(1.48-2.96)$
$2.49(1.75-3.50)$

$<0.0001$

$<0.0001$

1.00

$2.10(1.64-2.69)$

0.005

1.00

$1.26(0.71-2.21)$

$1.66(0.96-2.86)$

$1.84(1.02-3.32)$

0.009

1.00

$1.00(0.69-1.43)$

$1.00(0.71-1.42)$

$1.78(1.15-2.68)$

ESAS SHORTNESS OF BREATH $\quad 0.04$ SCORE

0

1-3

4-7

$1.30(0.97-1.74)$

8-10

$1.67(1.18-2.35)$

$1.33(0.85-2.08)$ 
Table 11

Maximum likelihood estimates of regression co-efficients $(\beta)$, their standard errors (SE), pertinent Wald's Statistics (Z), P-Values, and Partial Scores for the co-variates that were retained in the multivariate analysis as prognostic for survival

\begin{tabular}{|c|c|c|c|c|c|}
\hline & $\beta$ & $\operatorname{SE}(\beta)$ & $\mathbf{z}$ & P-Value & Partial Scor \\
\hline $\begin{array}{l}\text { MARY CANCER SITE } \\
\text { BREAST } \\
\text { PROSTATE } \\
\text { LUNG } \\
\text { OTHERS }\end{array}$ & $\begin{array}{l}0.00000 \\
0.66386 \\
0.74021 \\
0.91170\end{array}$ & $\begin{array}{l}0.22408 \\
0.17609 \\
0.18015\end{array}$ & $\begin{array}{l}8.7773 \\
17.6693 \\
25.6124\end{array}$ & $\begin{array}{l}0.0031 \\
<0.0001 \\
<0.0001\end{array}$ & $\begin{array}{l}0.0 \times 2=0 \\
2.5 \times 2=5 \\
3.0 \times 2=6 \\
3.5 \times 2=7\end{array}$ \\
\hline $\begin{array}{l}\text { E OF METASTASES } \\
\text { BONE METASTASES ONLY } \\
\text { OTHERS }\end{array}$ & $\begin{array}{l}0.00000 \\
0.72670\end{array}$ & 0.15089 & 23.1940 & $<0.0001$ & $\begin{array}{l}0.0 \times 2=0 \\
3.0 \times 2=6\end{array}$ \\
\hline $\begin{array}{l}>50 \\
\leq 50\end{array}$ & $\begin{array}{l}0.00000 \\
0.74292\end{array}$ & 0.12556 & 35.0069 & $<0.0001$ & $\begin{array}{l}0.0 \times 2=0 \\
3.0 \times 2=6\end{array}$ \\
\hline $\begin{array}{l}\text { AS FATIGUE SCORE } \\
\begin{array}{l}0 \\
1-3 \\
4-7 \\
8-10\end{array}\end{array}$ & $\begin{array}{l}0.00000 \\
0.22765 \\
0.50443 \\
0.61133\end{array}$ & $\begin{array}{l}0.28846 \\
0.27867 \\
0.30030\end{array}$ & $\begin{array}{l}0.6228 \\
3.2765 \\
4.1443\end{array}$ & $\begin{array}{l}0.4300 \\
0.0703 \\
0.0418\end{array}$ & $\begin{array}{l}0.0 \times 2=0 \\
0.0 \times 2=0 \\
2.0 \times 4=4 \\
2.5 \times 2=5\end{array}$ \\
\hline $\begin{array}{l}\text { AS APPETITE SCORE } \\
0 \\
1-3 \\
4-7 \\
8-10\end{array}$ & $\begin{array}{l}0.00000 \\
-0.00546 \\
0.00342 \\
0.56256\end{array}$ & $\begin{array}{l}0.18637 \\
0.17695 \\
0.21631\end{array}$ & $\begin{array}{l}0.0009 \\
0.0004 \\
6.7639\end{array}$ & $\begin{array}{l}0.9766 \\
0.9846 \\
0.0093\end{array}$ & $\begin{array}{l}0.0 \times 2=0 \\
0.0 \times 2=0 \\
0.0 \times 2=0 \\
2.0 \times 2=4\end{array}$ \\
\hline $\begin{array}{l}\text { AS SHORTNESS OF BREA } \\
\text { ORE }\end{array}$ & & & & & \\
\hline $\begin{array}{l}0 \\
1-3 \\
4-7 \\
8-10\end{array}$ & $\begin{array}{l}0.00000 \\
0.26165 \\
0.51255 \\
0.28496\end{array}$ & $\begin{array}{l}0.14915 \\
0.17514 \\
0.22822\end{array}$ & $\begin{array}{l}3.0774 \\
8.5640 \\
1.5590\end{array}$ & $\begin{array}{l}0.0794 \\
0.0034 \\
0.2118\end{array}$ & $\begin{array}{l}0.0 \times 2=0 \\
1.0 \times 2=2 \\
2.0 \times 2=4 \\
0.0 \times 2=0^{a}\end{array}$ \\
\hline
\end{tabular}

Pertinent Wald's statistics $(Z)$ is defined as the square of the ratio $(\beta / \operatorname{SE}(\beta))$

Steps in obtaining the partial score

1. Using a $10 \%$ level of significance, the value of each statistically significant regression co-efficient was divided by the smallest statistically significant regression co-efficient ( $\beta$ of 0.26165 for shortness of breath score $1-3$ ) among all regression co-efficients

2. The result was rounded to the nearest integer, or to the nearest integer +0.5

3. It was then multiplied by 2 to obtain whole number (partial score)

4. A zero was assigned to partial score if $p>0.1$

- To maintain face validity, a partial score of 4 was assigned to shortness of breath $8-10$ (see text). 
Table 12

Discrimination ( $\mathrm{C}$ Index) of the Final Model

$\begin{array}{cc}\text { Time } & \text { C Index } \\ 3 \text { months } & 0.73 \\ 6 \text { months } & 0.75 \\ 1 \text { year } & 0.81 \\ C \text { index of } 1=\text { perfect discrimination and } C \text { index of } 0.5 \text { indicates a model with no } \\ \text { discriminative ability at all. }\end{array}$

discriminative ability at all. 
Table 13

Risk Groups Based on the Survival Prediction Scores (SPS)

\begin{tabular}{|c|c|c|c|c|c|c|}
\hline $\begin{array}{c}\text { Risk } \\
\text { Groups } \\
\text { (SPS) }\end{array}$ & $\mathbf{N}$ & $\begin{array}{c}\text { Survival at 3 } \\
\text { months } \\
(\%) \\
(95 \% \text { C.I. })\end{array}$ & $\begin{array}{c}\text { Survival at } \\
6 \text { months } \\
(\%) \\
(95 \% \text { C.I. })\end{array}$ & $\begin{array}{c}\text { Survival at } \\
12 \text { months } \\
(\%) \\
(95 \% \text { C.I. })\end{array}$ & $\begin{array}{c}\text { Median } \\
\text { survival in } \\
\text { weeks } \\
(95 \% \text { C.I. })\end{array}$ & P-value \\
\hline $\mathrm{A}(0-13)$ & 133 & $83(77-90)$ & $70(62-78)$ & $51(42-60)$ & $53(38-70)$ & \\
$\mathrm{B}(14-19)$ & 129 & $67(59-76)$ & $41(33-50)$ & $20(13-27)$ & $19(17-26)$ & $<0.0001$ \\
$\mathrm{C}(20-32)$ & 133 & $36(28-44)$ & $18(11-24)$ & $4(1-7)$ & $8(6-10)$ & \\
\hline
\end{tabular}

$\mathrm{N}$ - number of patients 
Table 14

Risk Groups Based on the Total Number of Risk Factors Method

\begin{tabular}{|c|c|c|c|c|c|c|}
\hline $\begin{array}{c}\text { Risk Groups } \\
\text { (Total number } \\
\text { of risk factors) }\end{array}$ & $\mathbf{N}$ & $\begin{array}{c}\text { Survival at 3 } \\
\text { months } \\
(\%)\end{array}$ & $\begin{array}{c}\text { Survival at 6 } \\
\text { months } \\
(\%)\end{array}$ & $\begin{array}{c}\text { Survival at 12 } \\
\text { months } \\
(\%)\end{array}$ & $\begin{array}{c}\text { Median } \\
\text { survival in } \\
\text { weeks } \\
(95 \% \text { C.I.) }\end{array}$ & P-value \\
\hline I (0-3) & 98 & $85(78-92)$ & $72(63-81)$ & $52(42-63)$ & $62(41-70)$ & \\
II (4) & 117 & $68(60-77)$ & $47(38-57)$ & $24(16-32)$ & $24(18-29)$ & $<0.0001$ \\
III (5-6) & 180 & $46(38-53)$ & $24(18-31)$ & $11(6-16)$ & $11(9-14)$ & \\
\hline
\end{tabular}

$\mathrm{N}$ - number of patients 
Table 15

Prognostic Index/ Nomogram: Predicted Survival Probability (3 selected examples)

\begin{tabular}{|c|c|c|c|c|c|c|c|c|c|c|}
\hline Scenario & $\begin{array}{l}\text { KPS } \\
\text { Score }\end{array}$ & $\begin{array}{c}\text { Primary Cancer } \\
\text { Site }\end{array}$ & $\begin{array}{c}\text { Site of } \\
\text { Metastases }\end{array}$ & $\begin{array}{l}\text { Appetile } \\
\text { Score }\end{array}$ & $\begin{array}{l}\text { Fatigue } \\
\text { Score }\end{array}$ & $\begin{array}{l}\text { Shortness of } \\
\text { Breath Score }\end{array}$ & $\begin{array}{c}\text { Predicted Survival } \\
\text { Probability at } 3 \text { months } \\
\text { (95\% Cl) }\end{array}$ & $\begin{array}{c}\text { Predicted Survival } \\
\text { Probability at } 6 \text { months } \\
(95 \% \mathrm{Cl})\end{array}$ & $\begin{array}{c}\text { Predicted Survival } \\
\text { Probability at } 1 \text { year } \\
(95 \% \mathrm{CI})\end{array}$ & $\begin{array}{c}\text { Median } \\
\text { Survival in } \\
\text { weeks } \\
(95 \% \mathrm{Cl})\end{array}$ \\
\hline 42 & $>50$ & Breast & Bone Only & $4-7$ & $4-7$ & 1.3 & $0.90(0.85-0.94)$ & $0.81(0.73-0.89)$ & $0.66(0.55-0.79)$ & $93(51-)$ \\
\hline 686 & $\leq 50$ & Prostale & Bone Only & 4.7 & $8 \cdot 10$ & $1-3$ & $0.60(0.46-0.79)$ & $0.37(0.23 \cdot 0.62)$ & $0.15(0.06-0.40)$ & $18(9-27)$ \\
\hline 896 & $\leq 50$ & Lung & Others & $8-10$ & $8-10$ & 8.10 & $013(0.05 \cdot 0.33)$ & $0.02(0.00-0.11)$ & $0.00(0.00-0.02)$ & $5(3-7)$ \\
\hline
\end{tabular}

Blank in median survival $=$ not yet achieved 
i

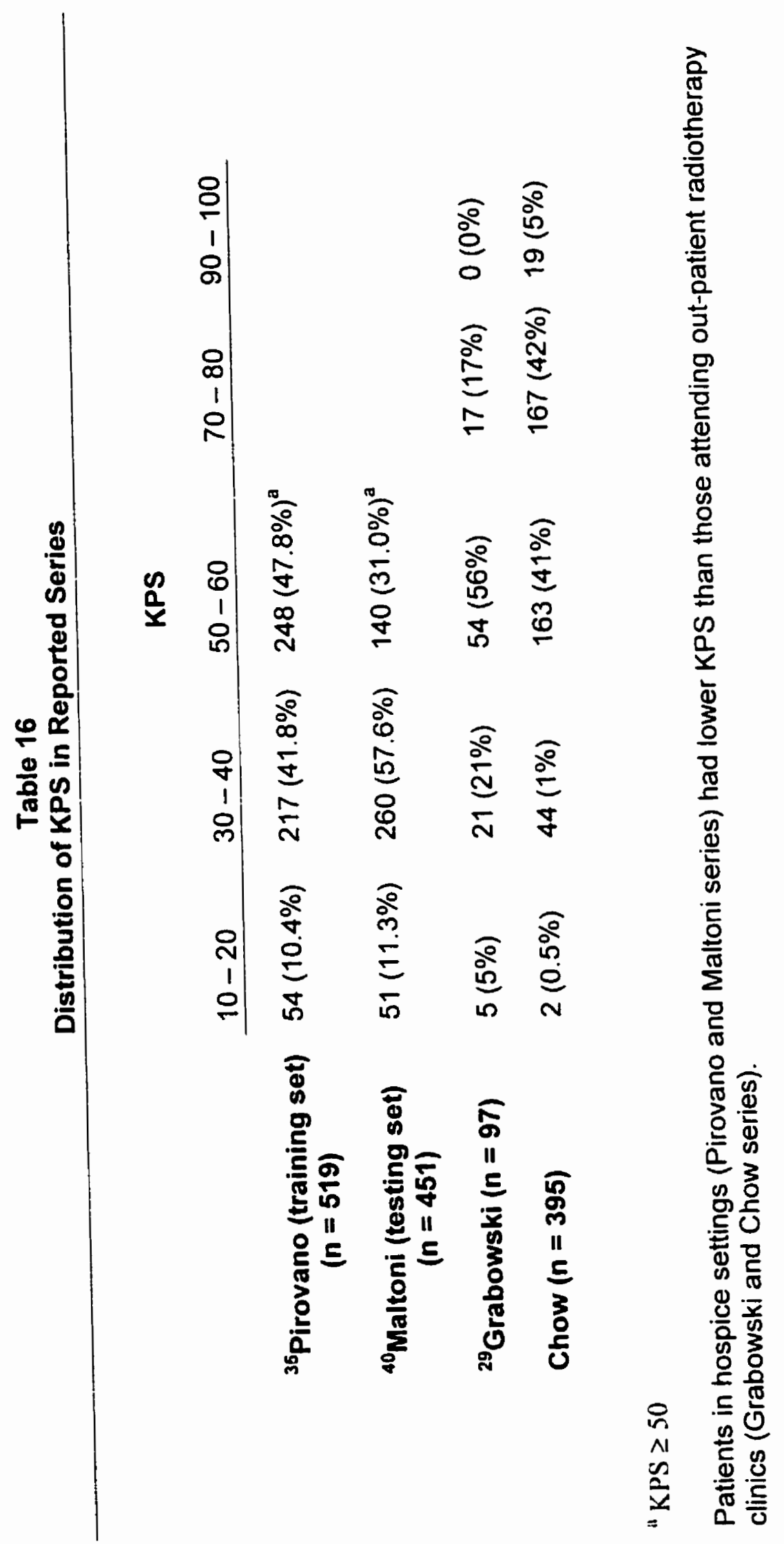


Table 17

Levels of Statistical Significance Reported for the Co-Variates

in Terminally III Cancer Patients in the Systematic Review by Vigano et al (15)

\begin{tabular}{|c|c|c|c|c|c|}
\hline Co-variate & $\begin{array}{l}\text { Not statistically } \\
\text { significant in the } \\
\text { univariate analysis } \\
\text { (UA) }\end{array}$ & $\begin{array}{c}\text { Statistically significant } \\
\text { in UA, not significant in } \\
\text { multi-variate analysis } \\
\text { (MA) }\end{array}$ & $\begin{array}{c}\text { Statistically significant in } \\
\text { MA }\end{array}$ & $\begin{array}{c}\text { Number } \\
\text { of } \\
\text { positive } \\
\text { studies / } \\
\text { total } \\
\text { number } \\
\text { evaluated }\end{array}$ & $\begin{array}{c}\text { Total } \\
\text { number of } \\
\text { patients } \\
\text { evaluated }\end{array}$ \\
\hline Low KPS & & $11,18,19^{\mathrm{a}}, 26^{\mathrm{a}}, 27,102^{\mathrm{a}}$ & $10^{b}, 20,31^{b}, 33^{b}, 35^{b}, 41^{b}, 103$ & $13 / 13$ & 6424 \\
\hline Primary cancer site ${ }^{c}$ & $4,10,20,31,34,102$ & $11^{\mathrm{a}}, 33^{\mathrm{a}}, 103$ & 32 & $4 / 9$ & 4025 \\
\hline Anorexia & 18 & 11,27 & $10^{b}, 20,27,34,35^{b}$ & $7 / 8$ & 3430 \\
\hline Dyspnea & 18 & & $4,10^{b}, 20,32,34,35^{b}$ & $6 / 7$ & 3258 \\
\hline
\end{tabular}

The numbers indicated under the second, third and fourth rows are reference numbers

significance at $p \leq 0.05$, if not otherwise specified

a - significance not tested / reported for MA

b - level of significance not reported for UA

c - lung primary in references 32,33, and $103 \quad$ gastrointestinal primary in reference 11 
Table 18

Pocket Reference Table for

Survival Prediction Score (SPS)

1. Primary cancer site

\section{Partial Score}

$\begin{array}{ll}\text { Breast } & 0 \\ \text { Prostate } & 5 \\ \text { Lung } & 6 \\ \text { others } & 7\end{array}$

2. Site of metastases

Bone only 0

$\begin{array}{ll}\text { Others } & 6\end{array}$

3. KPS
$>50$
0
$\leq 50$
6

4. Fatigue score

$\begin{array}{ll}0-3 & 0 \\ 4-7 & 4 \\ 8-10 & 5\end{array}$

5. Appetite score
$0-7$
$8-10$
0
4

6. Shortness of breath score
0
$1-3$
$4-10$
0
2
4

SPS $=$ Sum of partial scores of the above 6 groups

$\begin{array}{ccccc}\begin{array}{c}\text { Risk Group } \\ \text { (SPS) }\end{array} & \begin{array}{c}\text { Survival at 3 } \\ \text { months (\%) } \\ (\mathbf{9 5 \%} \mathrm{Cl})\end{array} & \begin{array}{c}\text { Survival at 6 } \\ \text { months (\%) } \\ (\mathbf{9 5 \%} \mathrm{Cl})\end{array} & \begin{array}{c}\text { Survival at 12 } \\ \text { months (\%) } \\ (\mathbf{9 5 \%} \mathrm{Cl})\end{array} & \begin{array}{c}\text { Median survival } \\ \text { (weeks) } \\ (\mathbf{9 5 \%} \mathrm{Cl})\end{array} \\ \mathrm{A}(0-13) & 83(77-90) & 70(62-78) & 51(42-60) & 53(38-70) \\ \mathrm{B}(14-19) & 67(59-76) & 41(33-50) & 20(13-27) & 19(17-26) \\ \mathrm{C}(20-32) & 36(28-44) & 18(11-24) & 4(1-7) & 8(6-10)\end{array}$


Table 19

Pocket Reference Table for

Number of Risk Factors

\section{Risk Factors}

- non breast cancer patients

- sites of metastases other than bone only

- KPS $\leq 50$

- fatigue score 4-10

- appetite score 8-10

- shortness of breath score 1-10

Risk Group (no of risk factors)

$1(0-3)$ II (4)

III $(5-6)$
Survival at 3 months (\%)

$(95 \%$ CI)

$85(78-92)$

$68(60-77)$

$46(38-53)$
Survival at 6 Survival at 12 months (\%) months (\%)

(95\% Cl)

$(95 \% \mathrm{Cl})$

$52(42-63)$

$24(16-32)$

$11(6-16)$
Median survival (weeks) $(95 \% \mathrm{Cl})$

$62(41-70)$ $24(18-29)$ $11(9-14)$ 
Figure 1

Overall Survival for all patients included and not included in the database

Overall Survival

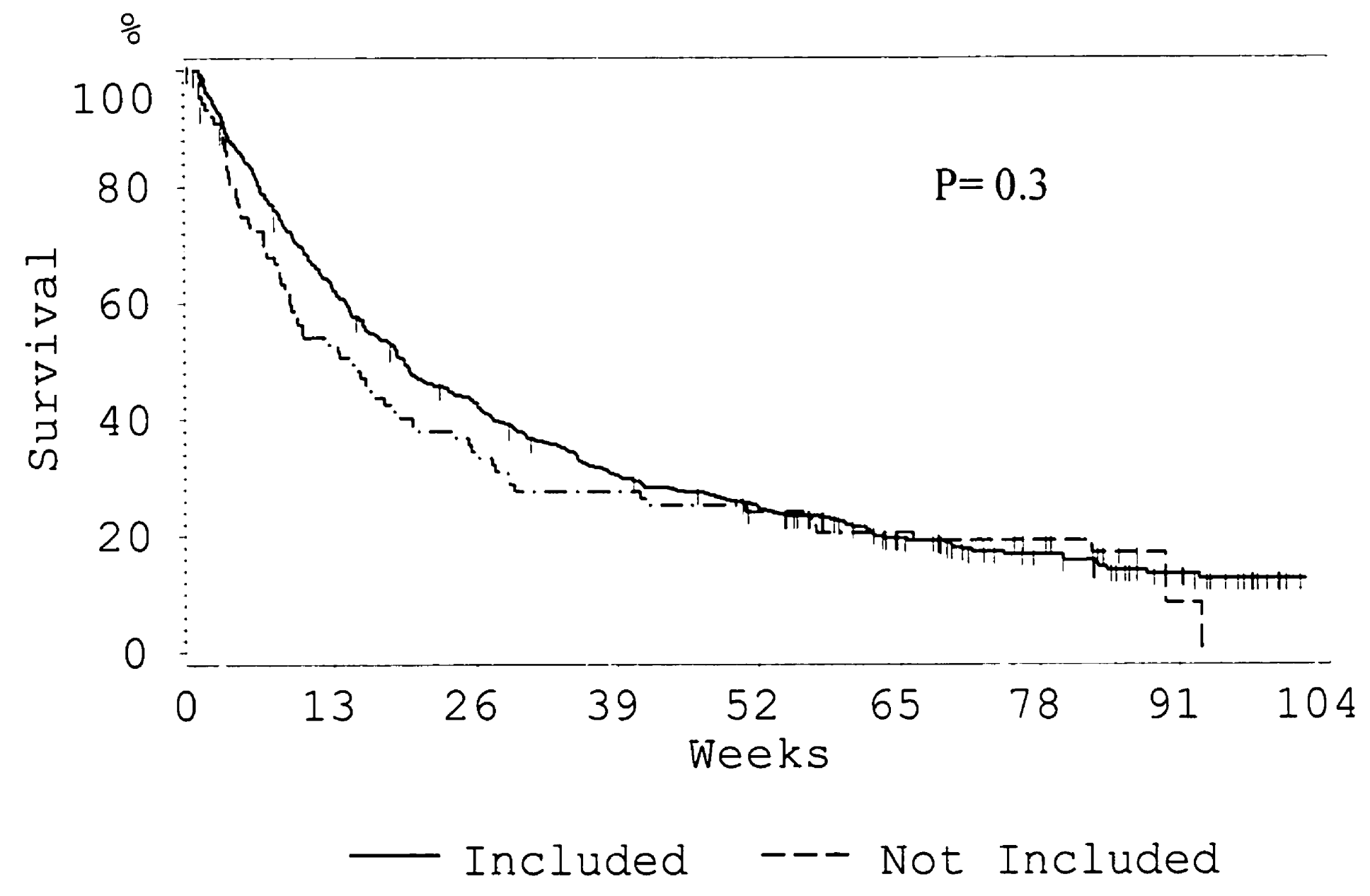


Figure 2

Frequency Distribution of the16 Potential Prognostic Factors That Were Included in the Model

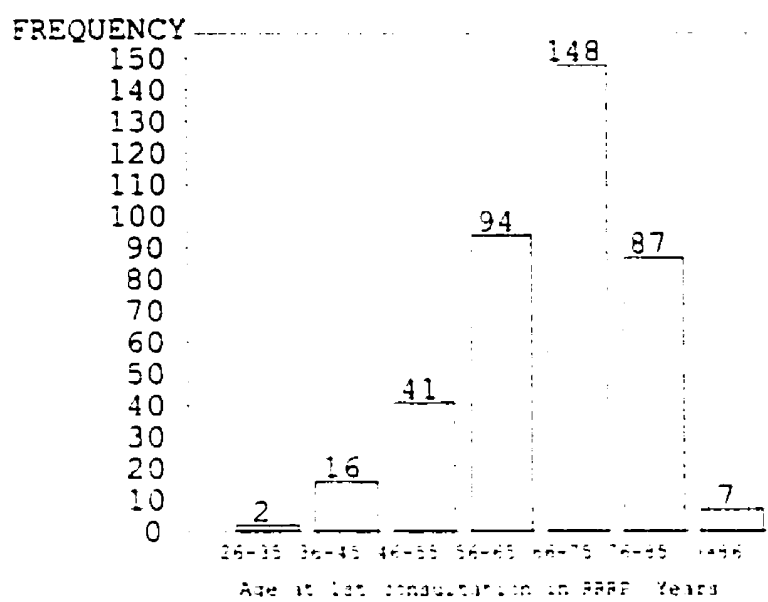

EREQUENCY

300

200

100

0

$$
\begin{aligned}
& \sqrt{300.02} \overline{3-2053} \\
& \text { : }: \text { : } \\
& \therefore: 5: 2-0519 \div 3003
\end{aligned}
$$

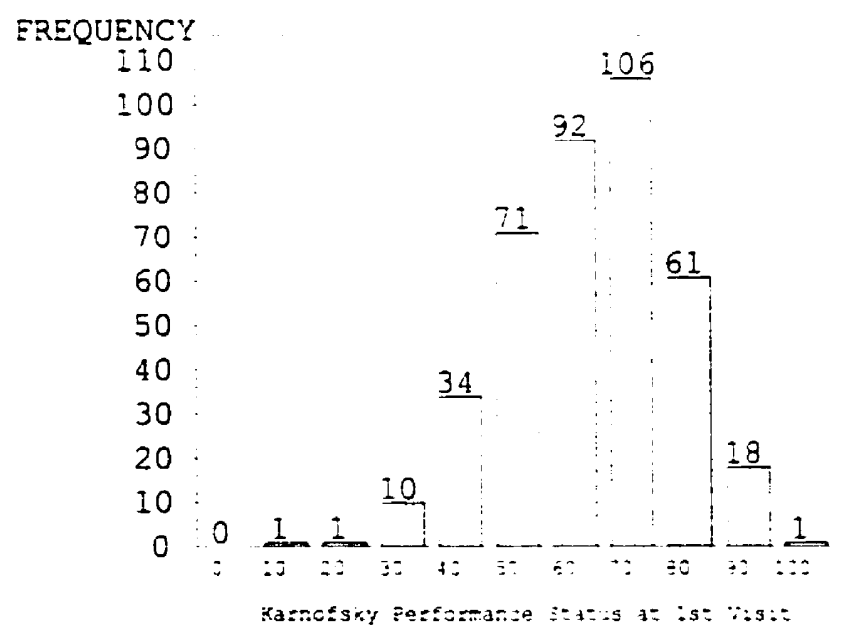

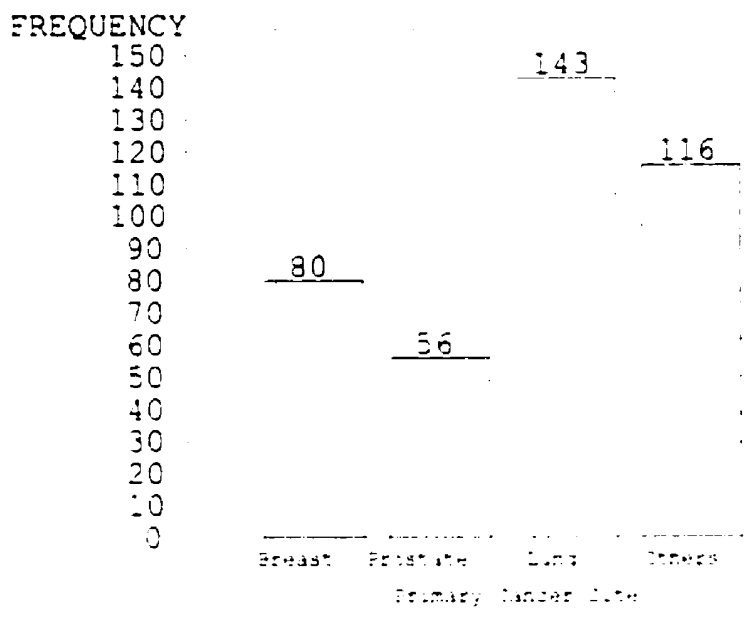

EEEQUEYCY

300

263

200

$\because 22$

200

0

4ie: :2: :-935
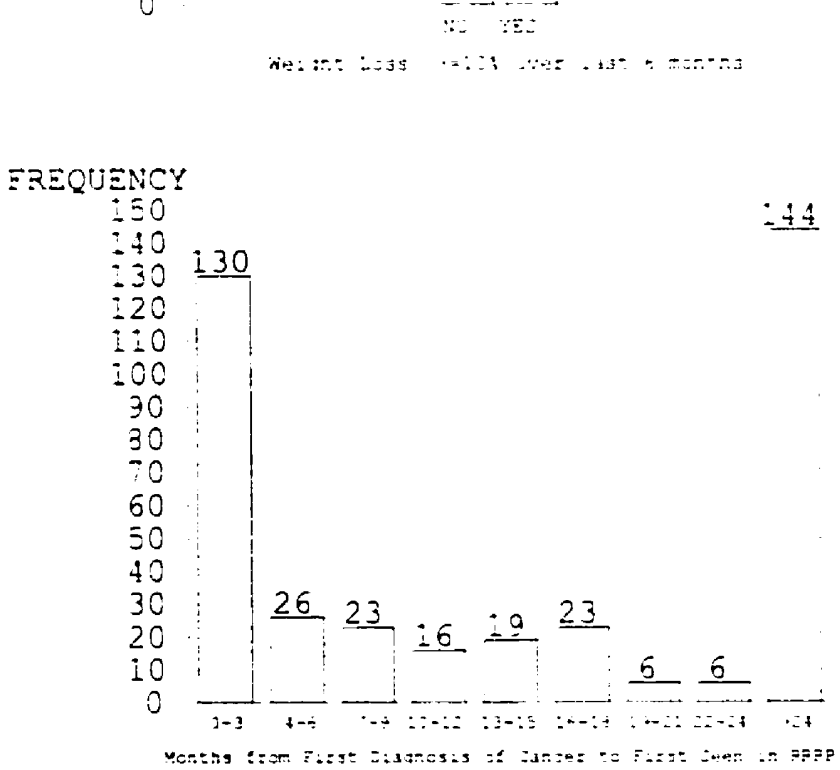
76

Figure 2

Frequency Distribution of the 16 Potential Prognostic Factors That Were Included in the Model

FREQUENCY

80

$70 \quad 7 !$

60

$30 \quad 43 \pm 4544$

is

30

20

22

26

:
FREQUENCY

9073

60

64

$50 \quad 46,43$

40

30

$3^{i}$

10

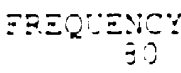

76.

?

$\therefore \quad 33$

$\because \quad \quad \because \quad+38$.

36

$2 C \quad: 6$

is

20 I?

20

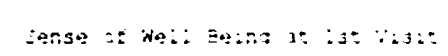

FREQUENCY

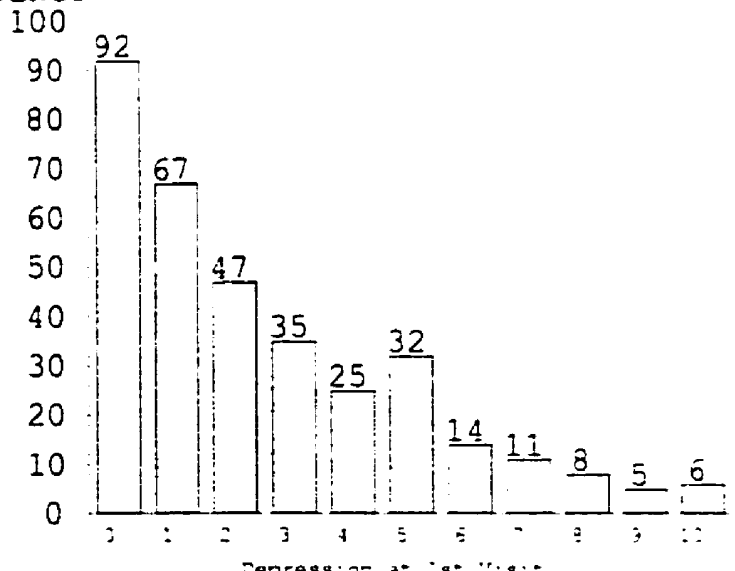

EREQHENC

$\div: 10$ is:

57

3435

$2024,13=$

3.5

30
20
30
0

$\pm \pm$

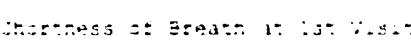

FREQUENCY

30

$70 \quad 22$

$60 \quad \underline{6 i}$

$50 \quad \underline{45}$

$40 \quad 37 \quad 33$

$20 \quad 23 \quad 22 \underline{17} \underline{28}$

$\pm 0$

79

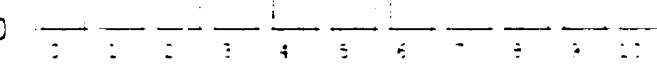

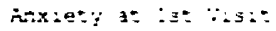


Figure $3 e$

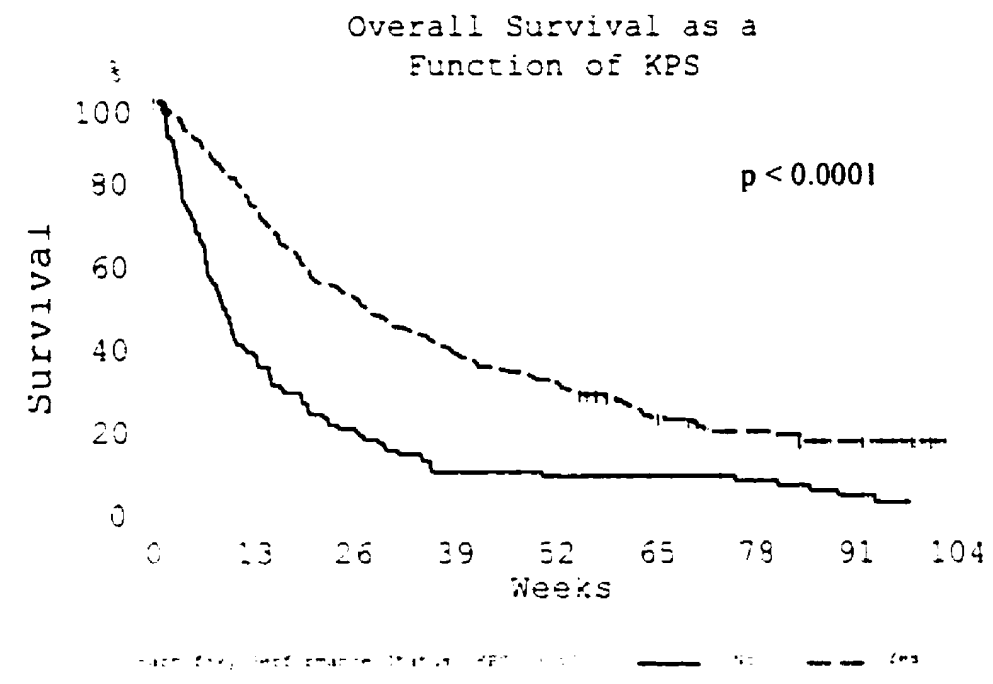

Figure $3 \mathrm{~g}$

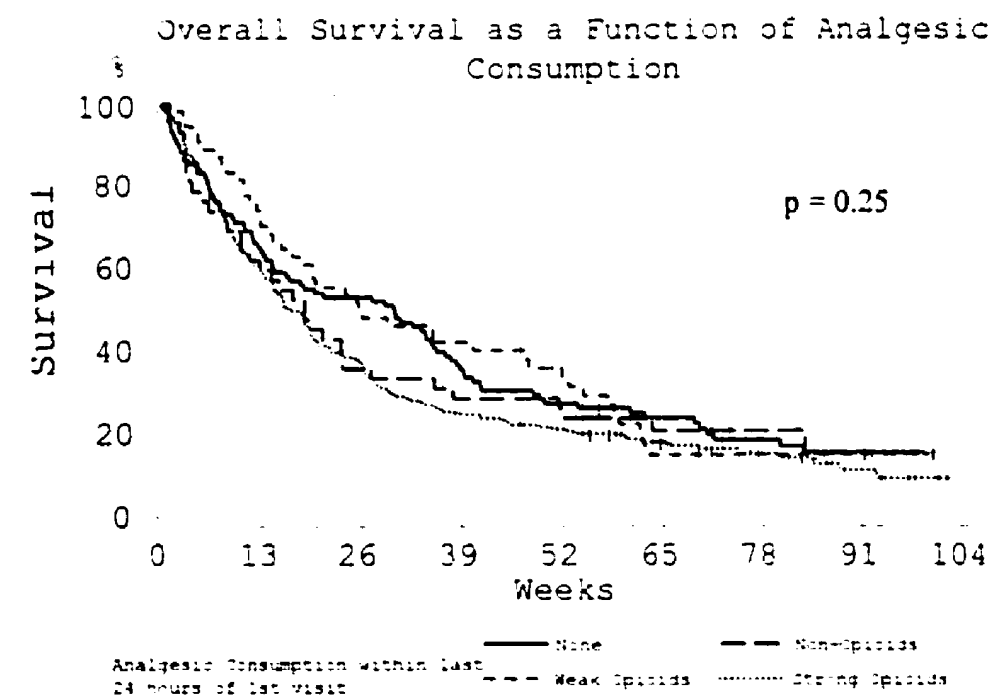

Figure $3 f$

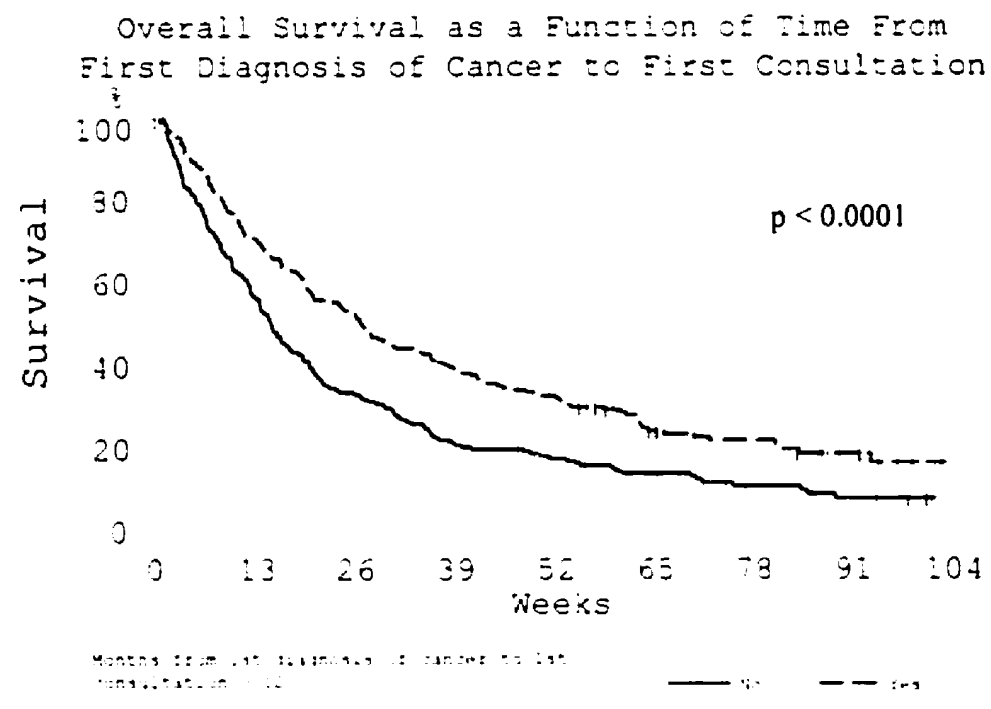

Figure $3 \mathrm{~h}$

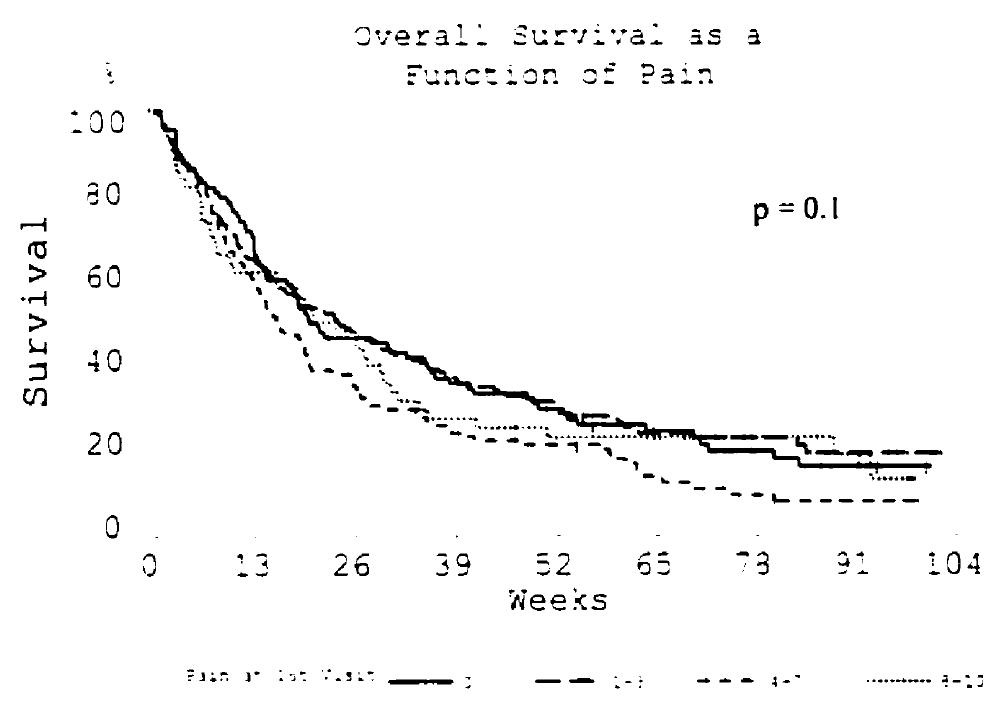


Figure $3 \mathrm{~m}$

Overall Survival as a Function of

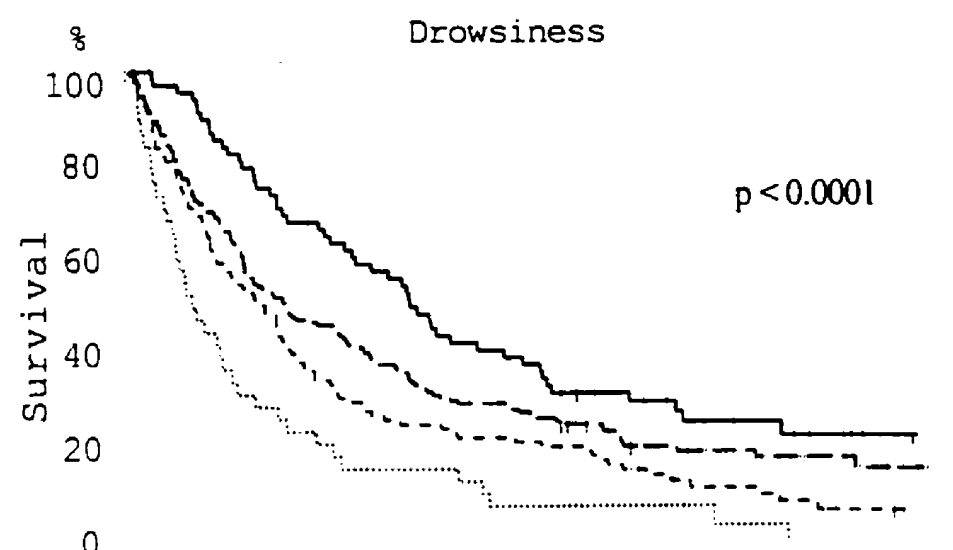

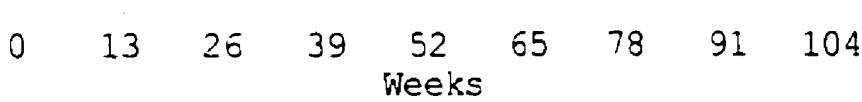

Figure 30

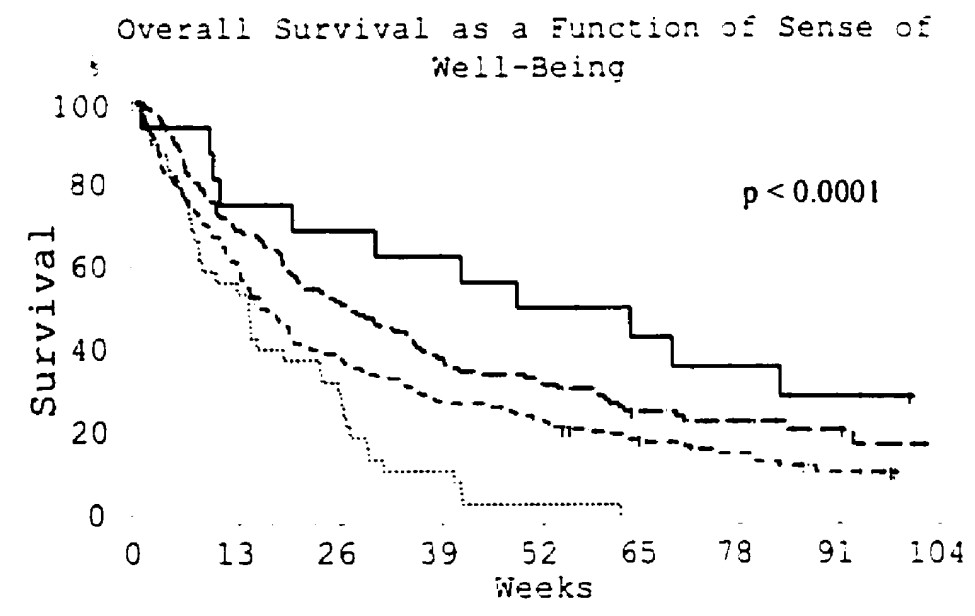

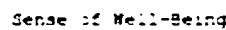
it is: is:
Figure 3n

Overall Survival as a Function of Appetite

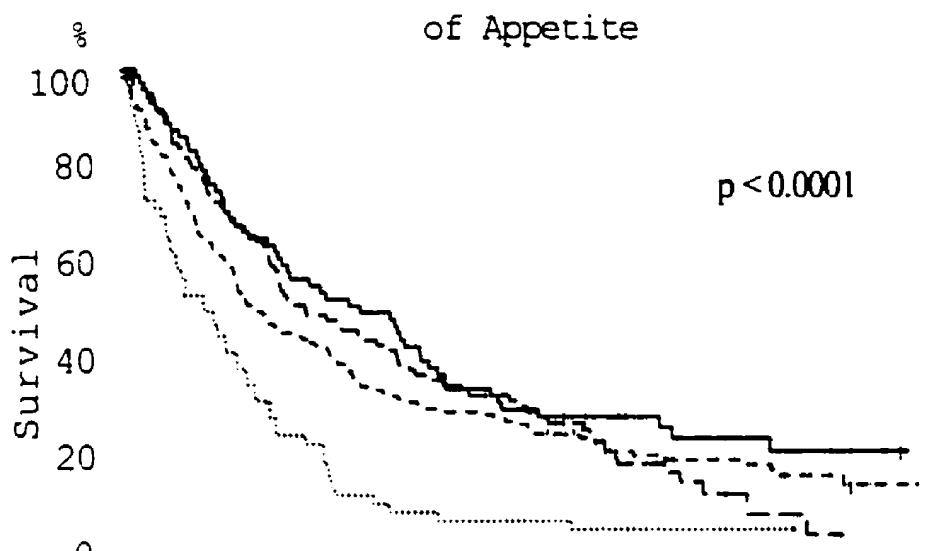

0 
Figure 4

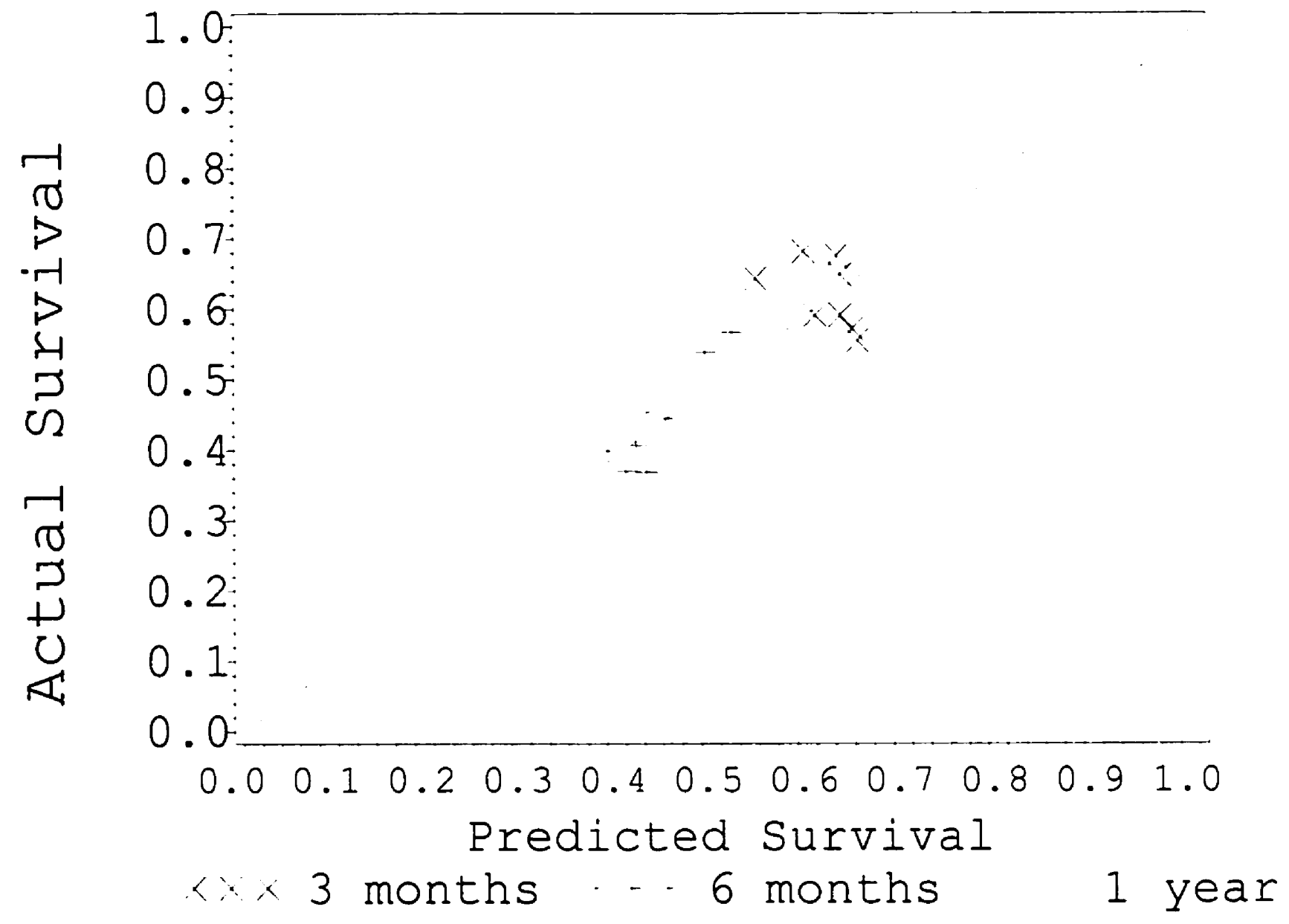

The average predicted survival probability of patients against the actual fraction of patients surviving past 3,6 , and 12 months was plotted 
Figure 5

Frequency Distribution of Survival Prediction Score (SPS) $(n=395)$

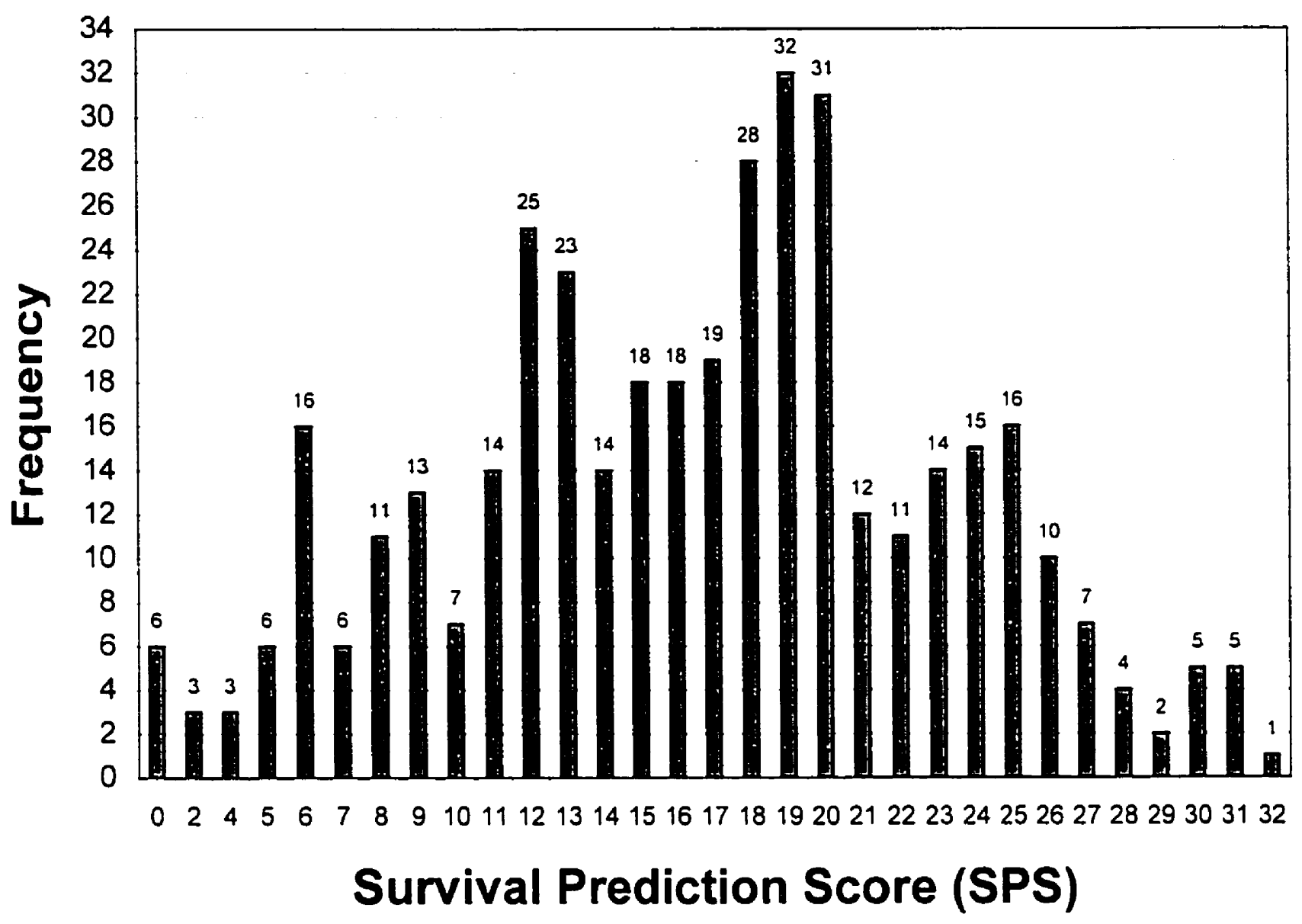

Survival Prediction Score (SPS) $=$ Primary Cancer Site Partial Score + Site of Metastases Partial Score + KPS Partial Score + Fatigue Partial Score + Appetite Partial Score + Shortness of Breath Partial Score 
Figure 6

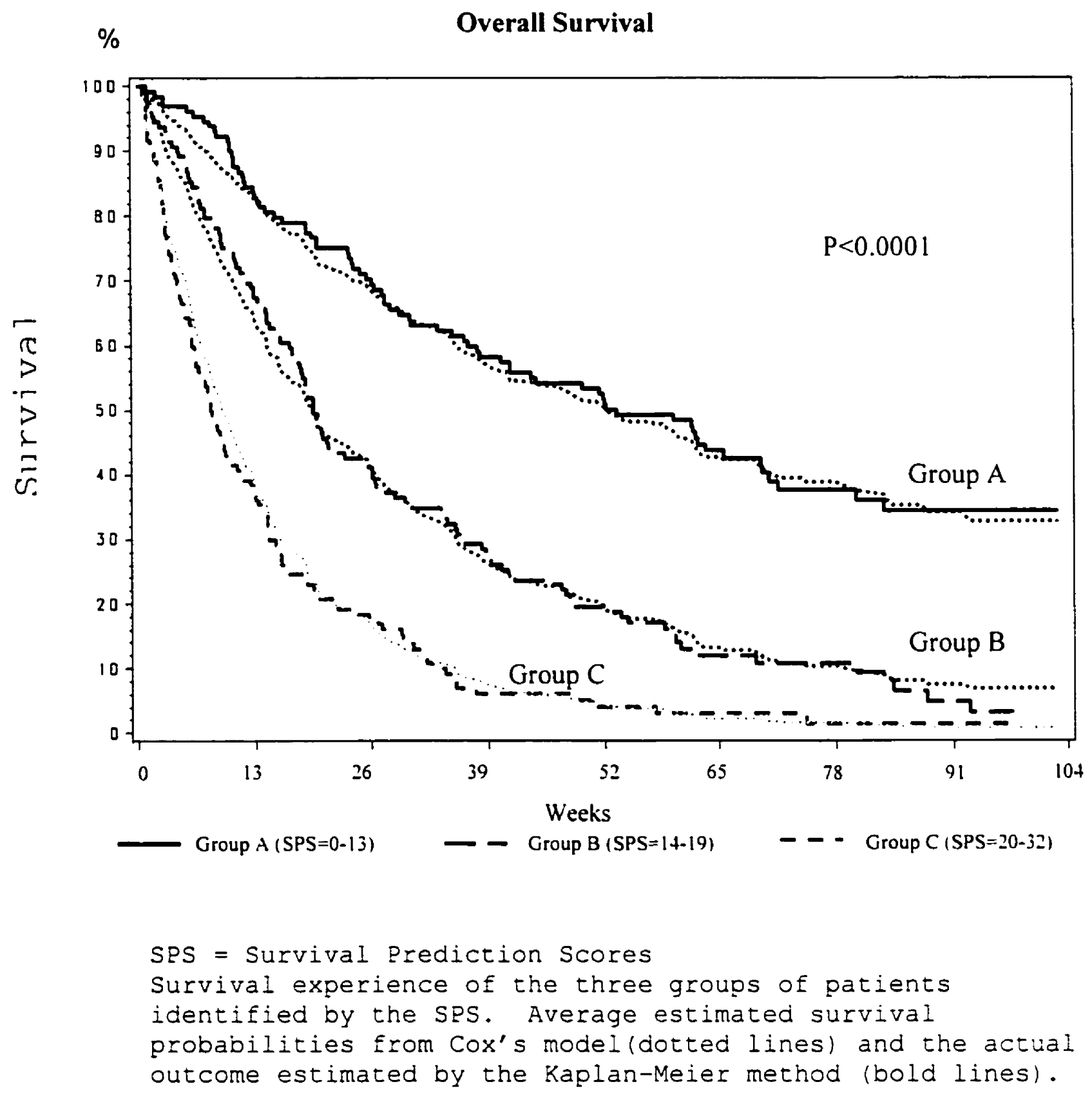


Figure 7

Frequency Distribution of Number of Risk Factors Patients Possessed ( $n=395)$

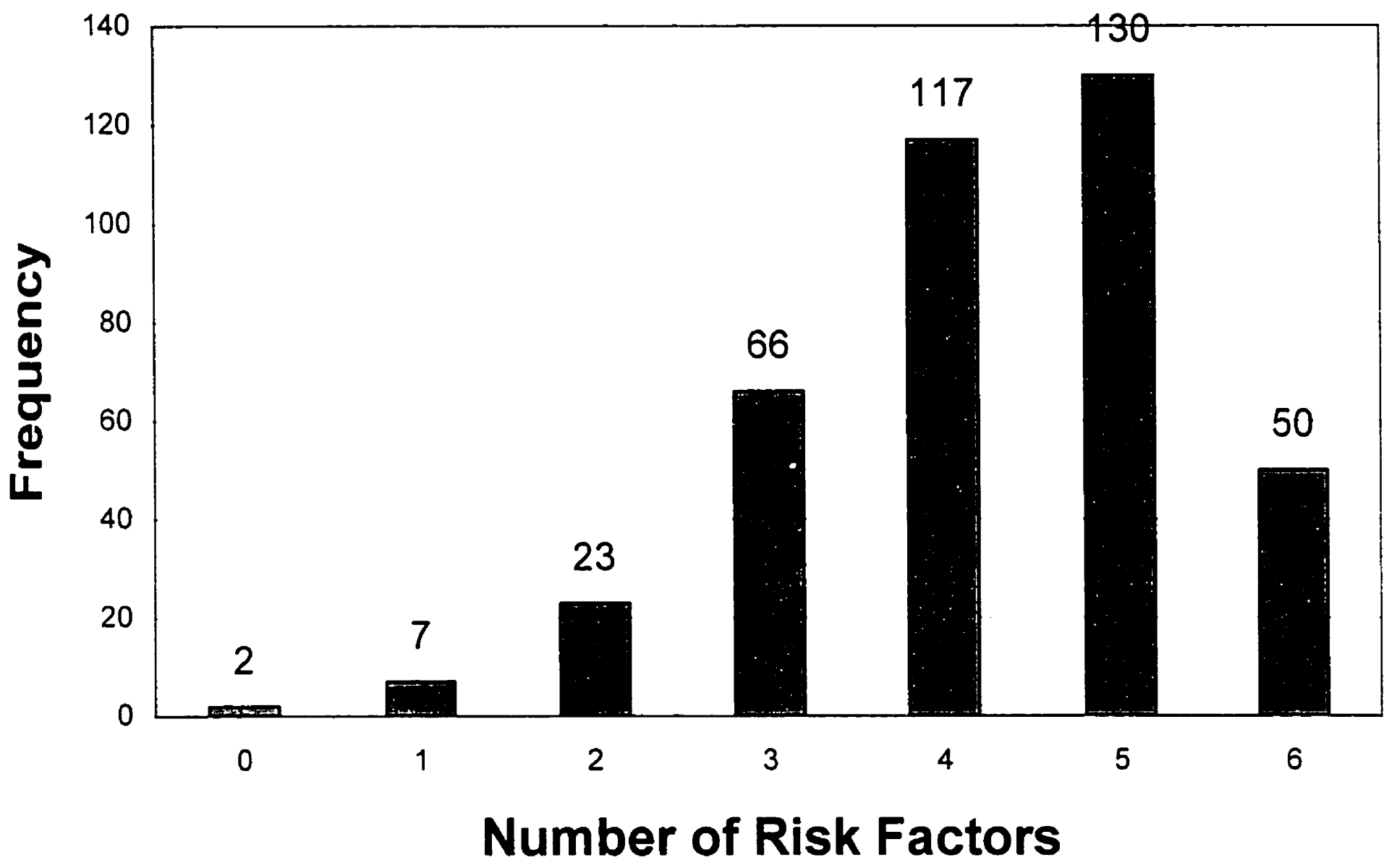


Figure 8

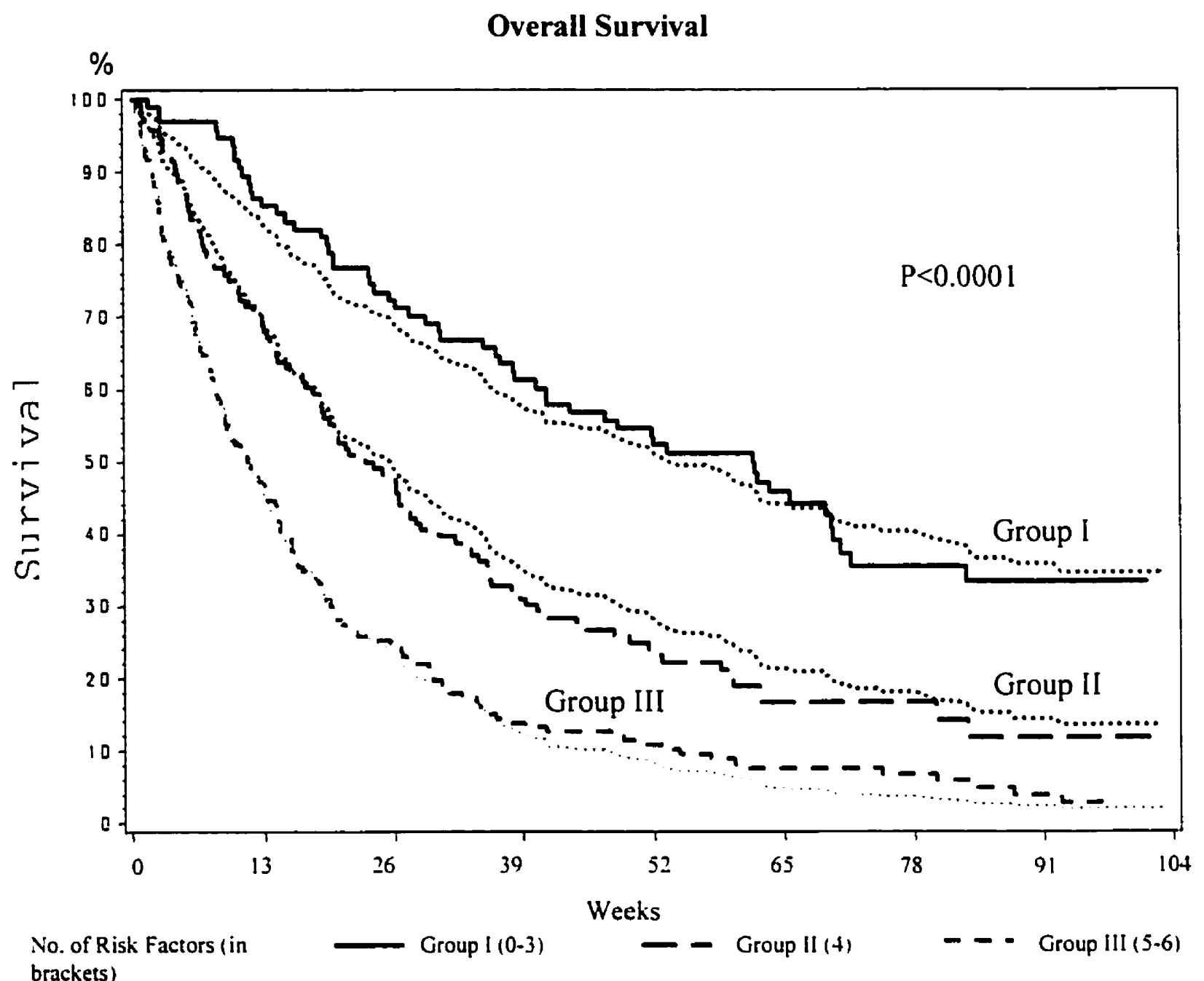

Survival experience of the three groups of patients identified by the number of risk factors. Average estimated survival probabilities from Cox's model (dotted Iines) and the actual outcome estimated by the Kaplan-Meier method (bold lines). 
Appendix 1

Classification Schemes (ref 104)

Category of Evidence

la-evidence for meta-analysis of randomised controlled trials

lb- evidence from at least one randomised controlled trial

lla- evidence from at least one controlled study without randomization

IIb- evidence from at least one other type of quasi-experimental study

III- evidence from non-experimental descriptive studies, such as comparative studies, correlation studies and case control studies

IV-evidence from expert committee reports or opinions or clinical experience of respected authorities or both

Strength of Recommendation

A- directly based on category I evidence

B- directly based on category $\mid 1$ evidence or extrapolated recommendation from category I evidence

C- directly based on category III evidence or extrapolated recommendation from category I or II evidence

D- directly based on category IV evidence or extrapolated recommendation from category I, II or III evidence 


\begin{tabular}{|cl|}
\hline Index & \multicolumn{1}{c|}{ Specific Criteria } \\
100 & $\begin{array}{l}\text { Normal, no complaints, no evidence of disease } \\
\text { Able to carry on normal activity, minor signs of symptoms } \\
\text { of disease } \\
\text { Normal activity with effort, some signs or symptoms of } \\
\text { disease } \\
\text { Cares for self, unable to carry on normal activity or to do } \\
\text { work } \\
\text { Requires occasional assistance from others but able to } \\
\text { care for most needs } \\
\text { Requires considerable assistance from others and } \\
\text { frequent medical care } \\
\text { Disabled, requires special care and assistance } \\
\text { Severely disabled, hospitalization indicated, death not } \\
\text { imminent } \\
\text { Very sick, hospitalization necessary, active supportive } \\
\text { treatment necessary } \\
\text { Moribund } \\
\text { Dead }\end{array}$ \\
\hline
\end{tabular}




\section{RRRP and BMC \\ $1^{\text {st }}$ Consultation and Assessment}

BH:

Date of Birth:

$\overline{\mathrm{DD}}{ }^{\prime} \frac{1}{\mathrm{MM}} \frac{}{\mathrm{YYYY}}$

Patient Name:

Gender: a Male $\square$ Female

Weight: $\mathrm{kg}$

Clinic: $\quad$ $\square$ RRRP

${ }_{2} \square$ BMC (Complete Orthopedic Assessment)

Date Seen:

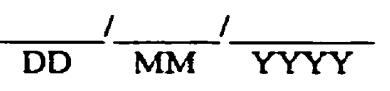

Staff Radiation Oncologist:

Patient coming by ambulance? $\quad 0$ No $\quad$ N Yes

From: $\quad{ }_{1}$ Home ${ }_{2}$ Hospital/Hospice ${ }_{3}$ Other:

Referring Physician:

Date of Referral:

Reasons for referral (Check as many as apply):

1 1 Bone mets

2 $\square$ Bone pain

${ }_{3} \square$ Other pain

, Bleeding

50 Shortness of breath

6 High risk for path. Fracture

, $\mathrm{Dathologic}$ fracture

8 Mass

, O Brain mets

${ }_{10} 0$ Cord compression

110 Cauda equina syndrome

${ }_{12}$ SVCO symptoms

${ }_{13}$ Q Unknown

1,0 Other:

\section{Disease History}

Primary Cancer Site (Check only one):

10 Breast

${ }_{2} \square$ Prostate

${ }_{3}$ L Lung

40 Head \& Neck

,D Bladder

${ }_{6}$ O Esophagus

70 Pancreas

${ }_{8}$ S Stomach/Gastric

, Q Renal Cell/ Kidncy

${ }_{10} \square$ Endometrium

11 O Ovarian

${ }_{12}$ 口 Colorectal

${ }_{13}$ Anal Canal

${ }_{14} \square$ Multiple Myeloma

is Unknown

${ }_{16} \mathrm{O}$ Other:

Date of $1^{\text {st }}$ Diagnosis of Malignancy:

(Date of $\mathrm{Bx}$ if available)

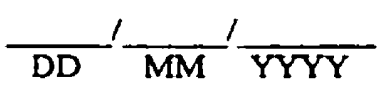

Pathology:

1] Adeno ca

20 Squamous cell

${ }_{4} \square$ Unknown

${ }_{3}$ 口 Multiple myeloma

s 0 Other: 
Metastases:

\begin{tabular}{|l|l|l|l|l|l|}
\hline \multicolumn{1}{|c|}{ Site } & None & Unknown & Single & Multiple & $\begin{array}{r}\text { Date of Dx } \\
\text { (mm-yyyy) }\end{array}$ \\
\hline Brain & & & & & \\
\hline Liver & & & & & \\
\hline Bone & & & & & \\
\hline Lymph nodes & & & & & \\
\hline Lung & & & & & \\
\hline Soft tissue & & & & & \\
\hline
\end{tabular}

Palliative Treatments within past 3 months:

$\begin{array}{llll}\text { Chemo: } & 0 \text { No } & 1 \square \text { Yes } & { }_{2} \square \text { Unknown } \\ \text { Hormones: } & { }_{0} \square \text { No } & 1 \square \text { Yes } & { }_{2} \square \text { Unknown } \\ \text { Bisphosphonates: } & { }_{0} \square \text { No } & 1 \square \text { Yes } & { }_{2} \square \text { Unknown }\end{array}$

Radiation: $\quad{ }_{0} \square$ No $\quad, \square$ Yes (Complete Details Below) ${ }_{2} \square$ Unknown

\begin{tabular}{|c|c|c|c|}
\hline Site & Dose/Fractionation & $\begin{array}{c}\text { Start date } \\
\text { (dd-mm-yyyy) }\end{array}$ & $\begin{array}{c}\text { Stop date } \\
\text { (dd-mm-yyyy) }\end{array}$ \\
\hline & & & \\
\hline & & & \\
\hline & & & \\
\hline
\end{tabular}

\begin{tabular}{|c|c|c|}
\hline Surgery: & Yes (Complete Details Below) & ${ }_{2}$ Q Unknown \\
\hline Site & Procedure & $\begin{array}{c}\text { Date } \\
\text { (dd-mm-yyyy) }\end{array}$ \\
\hline & & \\
\hline & 1 & \\
\hline & $i$ & \\
\hline
\end{tabular}

Patient Assessment:

Completed by: With:

10 Patient $\quad 20$ Family $\quad, \square$ RN

Other:

Weight loss $\geq 10 \%$ in the past 6 months: $\quad{ }_{0} \square$ No $\quad 10$ Yes $\quad{ }_{2} \square$ Unknown

Karnofsky Performance Status:

Analgesic Intake (Previous 24 Hours \& Changes During Visit):

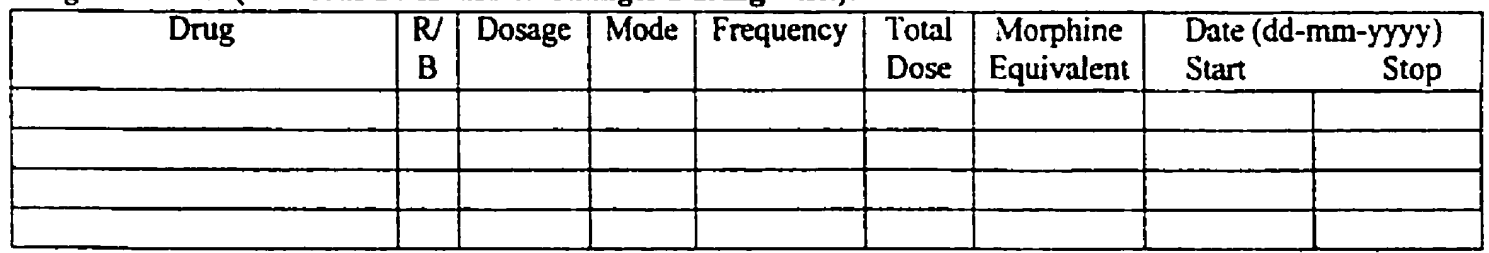

Other Medications (Previous 24 Hours \& Changes During Visit):

\begin{tabular}{|l|l|l|l|l|l|}
\hline & Dosage & Mode & Frequency & \multicolumn{2}{|c|}{ Date (dd-mm-yyyy) } \\
Start & & & \\
\hline & & & & & \\
\hline & & & & & \\
\hline
\end{tabular}




\section{Sitè Specific Pain Scores:}

Site:

$\begin{array}{lllllllllll}0 & 1 & 2 & 3 & 4 & 5 & 6 & 7 & 8 & 9 & 10 \\ \text { No pain } & & & & & & & & & \text { Worst possible pain }\end{array}$

Site:

$\begin{array}{llllllllll}0 & 1 & 2 & 3 & 4 & 5 & 6 & 7 & 8 & 9\end{array} \begin{aligned} & 10 \\ & \text { No pain }\end{aligned}$

Site:

$\begin{array}{lllllllllll}0 & 1 & 2 & 3 & 4 & 5 & 6 & 7 & 8 & 9 & \begin{array}{l}10 \\ \text { Wo pain }\end{array} \\ & & & & & & & & & \text { Worst possible pain }\end{array}$

\section{Global Scores:}

\begin{tabular}{|c|c|c|c|c|c|c|c|c|c|}
\hline $\begin{array}{ll}0 & 1 \\
\text { No pain }\end{array}$ & 2 & 3 & 4 & 5 & 6 & 7 & 8 & 9 & $\begin{array}{l}10 \\
\text { Worst possible pain }\end{array}$ \\
\hline $\operatorname{lot}_{\text {Nired }}^{1}$ & 2 & 3 & 4 & 5 & 6 & 7 & 8 & 9 & $\begin{array}{l}10 \\
\text { Worst possible tiredness }\end{array}$ \\
\hline $\begin{array}{ll}0 & 1 \\
\text { No nausea }\end{array}$ & 2 & 3 & 4 & 5 & 6 & 7 & 8 & 9 & $\begin{array}{l}10 \\
\text { Worst possible nausea }\end{array}$ \\
\hline $\begin{array}{l}0 \quad 1 \\
\text { Not depressed }\end{array}$ & 2 & 3 & 4 & 5 & 6 & 7 & 8 & 9 & $\begin{array}{l}10 \\
\text { Worst possible depression }\end{array}$ \\
\hline $\begin{array}{l}0 \quad 1 \\
\text { Not anxious }\end{array}$ & 2 & 3 & 4 & 5 & 6 & 7 & 8 & 9 & $\begin{array}{l}10 \\
\text { Worst possible anxiety }\end{array}$ \\
\hline $\begin{array}{l}0 \\
\text { Not drowsy }\end{array}$ & 2 & 3 & 4 & 5 & 6 & 7 & 8 & 9 & $\begin{array}{l}10 \\
\text { Worst possible drowsines }\end{array}$ \\
\hline $\begin{array}{l}0 \\
\text { Best possible ap }\end{array}$ & 2 & 3 & 4 & 5 & 6 & 7 & 8 & 9 & $\begin{array}{l}10 \\
\text { No appetite }\end{array}$ \\
\hline $\begin{array}{l}0 \\
\text { Best sense } \\
\text { of well being }\end{array}$ & 2 & 3 & 4 & 5 & 6 & 7 & 8 & 9 & $\begin{array}{l}10 \\
\text { Worst possible } \\
\text { sense of well being }\end{array}$ \\
\hline $\begin{array}{l}0 \quad 1 \\
\text { No shortness } \\
\text { Of breath }\end{array}$ & 2 & 3 & 4 & 5 & 6 & 7 & 8 & 9 & $\begin{array}{l}10 \\
\text { Worst possible } \\
\text { shormess of breath }\end{array}$ \\
\hline
\end{tabular}

Other.

$\begin{array}{lllllllllll}0 & 1 & 2 & 3 & 4 & 5 & 6 & 7 & 8 & 9 & 10 \\ \text { Best possible } & & & & & & & & & \text { Worst possible }\end{array}$

Other.

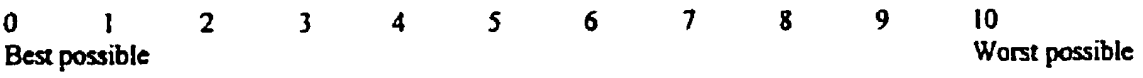


Main Reason For Visit (Decided By Radiation Oncologist):

, Bone Pain $\rightarrow$ Please indicate if ${ }_{1} \square$ Neuropathic ${ }_{2} \square$ Incidental ${ }_{3} \square$ Mechanical

$\begin{array}{lll}{ }_{2} \square \text { Other Pain } & { }_{5} \square \text { Cauda Equina Syndrome } & { }_{8} \square \text { Cord Compression } \\ { }_{3} \square \text { Shortness of breath } & { }_{6} \square \text { Bleeding } & 9 \text { SVCO Symptoms } \\ { }_{4} \square \text { Brain Mets } & { }_{7} \square \text { Mass } & 10 \square \text { Other: }\end{array}$

Radiation Oncologist's estimate of patient's survival (confidential): weeks or months

Participation in current Clinical Trials at TSRCC?: o No , , Y Yes If yes, please state protocol:

\section{Recommendations}

\section{Referral to Other Services:}

1D Orthopedics (Other than BMC)

20 Medical Oncology

; Pain Clinic

${ }_{4}$ O Psychosocial

\section{Treatments Recommended:}

\section{RRRP}

\begin{tabular}{|c|c|c|c|c|}
\hline Site & $\begin{array}{c}\text { RT } \\
\text { (Yes/No) }\end{array}$ & $\begin{array}{c}\text { If "Yes", } \\
\text { Dose/Fractionation }\end{array}$ & $\begin{array}{c}\text { Start Date } \\
\text { (dd-mm-yyyy) }\end{array}$ & If "No", Reason \\
\hline & & & & \\
\hline & & & & \\
\hline & & & & \\
\hline
\end{tabular}

BMC

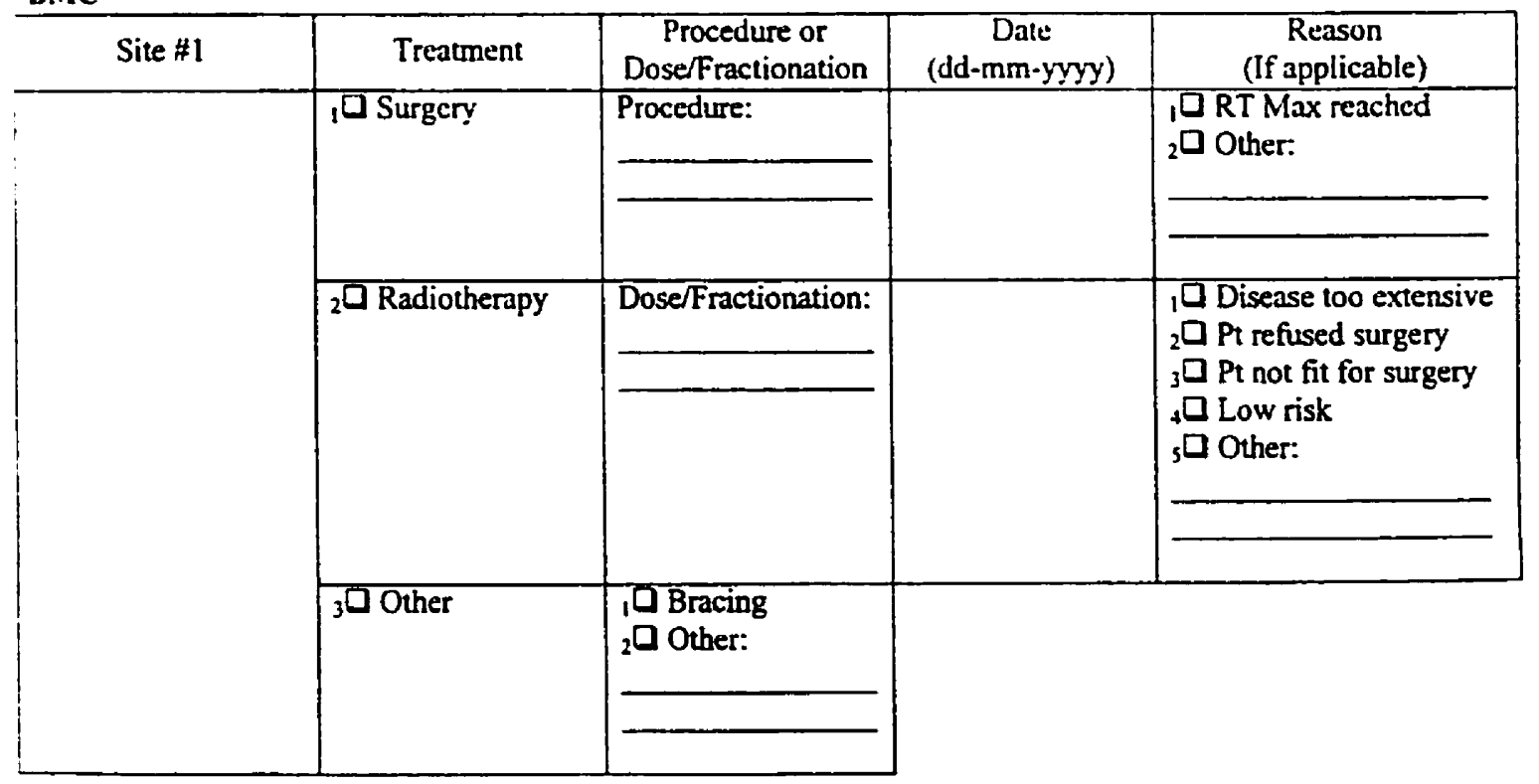




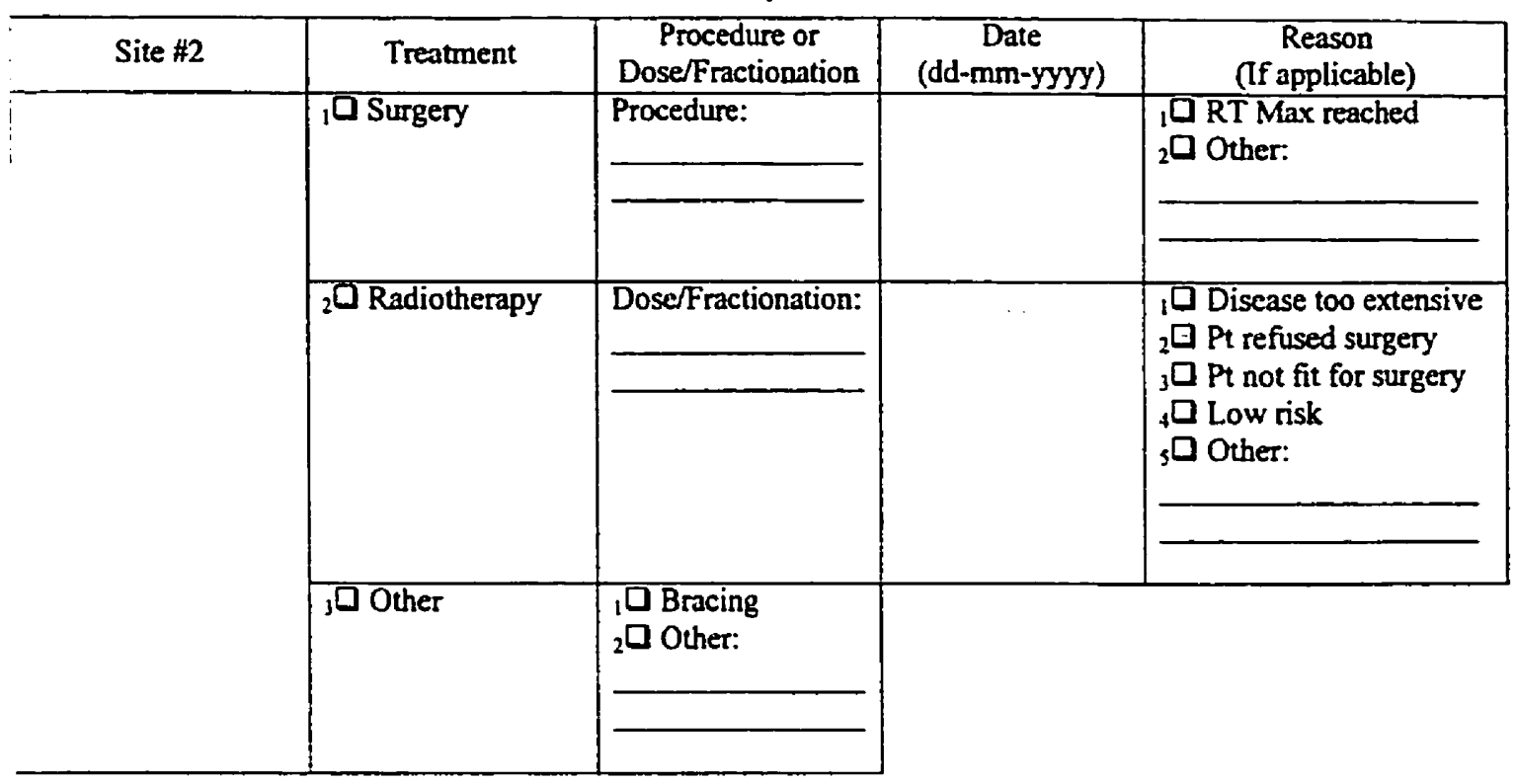

Follow-up Arrangements:

Referring Physicians

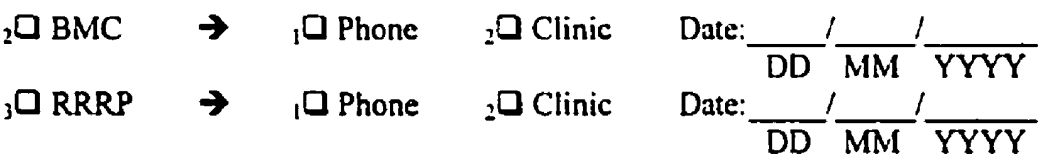

4 Orthopedic Clinic (Other than BMC)

s Other:

Comments: 


\section{Appendix 4}

Prognostic Index/ Nomogram: Predicted Survival Probability

\begin{tabular}{|c|c|c|c|c|c|c|c|c|c|c|}
\hline Scenario & $\begin{array}{l}\text { KPS } \\
\text { Score }\end{array}$ & $\begin{array}{c}\text { Primary Cancer } \\
\text { Site }\end{array}$ & $\begin{array}{c}\text { Site of } \\
\text { Melaslases }\end{array}$ & $\begin{array}{l}\text { Appetite } \\
\text { Score }\end{array}$ & $\begin{array}{l}\text { Fatigue } \\
\text { Score }\end{array}$ & $\begin{array}{l}\text { Shortness of } \\
\text { Breath Score }\end{array}$ & $\begin{array}{l}\text { Predicted Survival } \\
\text { Probability at } 3 \text { months } \\
(95 \% \mathrm{Cl})\end{array}$ & $\begin{array}{c}\text { Predicted Survival } \\
\text { Probability at } 6 \text { months } \\
(95 \% \mathrm{Cl})\end{array}$ & $\begin{array}{l}\text { Predicted Survival } \\
\text { Probability at } 1 \text { year } \\
(95 \% \mathrm{Cl})\end{array}$ & $\begin{array}{l}\text { Median } \\
\text { Survival in } \\
\text { weeks } \\
(95 \% \mathrm{CI})\end{array}$ \\
\hline 1 & $>50$ & Breast & Bone Only & 0 & 0 & 0 & $0.95(0.92-0.98)$ & $0.90(0.85-0.97)$ & $0.83(0.73-0.94)$ & \\
\hline 2 & $>50$ & Breast & Bone Only & 0 & 0 & 1.3 & $0.94(0.89-0.98)$ & $0.88(0.80-0.96)$ & $0.78(0.65-0.93)$ & \\
\hline 3 & $>50$ & Breast & Bone Only & 0 & 0 & 4.7 & $0.92(0.86-0.98)$ & $0.85(0.75-0.96)$ & $0.73(0.58-0.92)$ & \\
\hline 4 & $>50$ & Breast & Bone Only & 0 & 0 & $8 \cdot 10$ & $0.93(0.88-0.99)$ & $0.88(0.79-0.97)$ & $0.77(0.63-0.95)$ & \\
\hline 5 & $>50$ & Breast & Bone Only & 0 & $1-3$ & 0 & $0.94(0.91-0.97)$ & $0.88(0.83-0.94)$ & $0.79(0.70-0.89)$ & \\
\hline 6 & $>50$ & Breast & Bone Only & 0 & $1-3$ & 1.3 & $0.92(0.88-0.96)$ & $0.85(0.78-0.93)$ & $0.73(0.62-0.86)$ & \\
\hline 7 & $>50$ & Breast & Bone Only & 0 & $1-3$ & 4.7 & $0.90(0.84-0.96)$ & $0.81(0.72-0.91)$ & $0.67(0.53-0.84)$ & \\
\hline 8 & $>50$ & Breast & Bone Only & 0 & 1.3 & $8-10$ & $0.92(0.87-0.97)$ & $0.85(0.76-0.94)$ & $0.73(0.59-0.89)$ & \\
\hline 9 & $>50$ & Breast & Bone Only & 0 & $4-7$ & 0 & $0.92(0.88-0.96)$ & $0.85(0.77-0.93)$ & $0.73(0.62-0.86)$ & \\
\hline 10 & $>50$ & Breast & Bone Only & 0 & $4-7$ & 1.3 & $0.90(0.84-0.95)$ & $0.81(0.72-0.90)$ & $0.66(0.54-0.82)$ & \\
\hline 11 & $>50$ & Breast & Bone Only & 0 & 4.7 & 4.7 & $0.87(0.80-0.94)$ & $0.76(0.65 \cdot 0.89)$ & $0.59(0.44-0.79)$ & $70(29-)$ \\
\hline 12 & $>50$ & Breast & Bone Only & 0 & $4-7$ & $8 \cdot 10$ & $0.89(0.83-0.96)$ & $0.80(0.70-0.92)$ & $0.66(0.50-0.86)$ & $93(30-)$ \\
\hline 13 & $>50$ & Breast & Bone Only & 0 & $8-10$ & 0 & $0.91(0.86-0.96)$ & $0.83(0.75 \cdot 0.92)$ & $0.70(0.58-0.85)$ & \\
\hline 14 & $>50$ & Breast & Bone Only & 0 & $8-10$ & $1-3$ & $0.88(0.82-0.95)$ & $0.79(0.69-0.90)$ & $0.63(0.49-0.81)$ & $83(35-)$ \\
\hline 15 & $>50$ & Breast & Bone Only & 0 & $8-10$ & 4.7 & $0.85(0.78-0.94)$ & $0.73(0.61-0.88)$ & $0.55(0.39-0.78)$ & $62(25-)$ \\
\hline 16 & $>50$ & Breast & Bone Only & 0 & $8 \cdot 10$ & $8-10$ & $0.88(0.81-0.96)$ & $0.78(0.67-0.91)$ & $0.62(0.47-0.83)$ & $83(28-)$ \\
\hline 17 & $>50$ & Breast & Bone Only & 1.3 & 0 & 0 & $0.95(0.92 .098)$ & $0.91(0.85-0.97)$ & $0.83(0.73-0.94)$ & \\
\hline 18 & $>50$ & Breast & Bone Only & $1-3$ & 0 & 1.3 & $0.94(0.89 .098)$ & $0.88(0.80-0.96)$ & $0.78(0.66-0.92)$ & \\
\hline 19 & $>50$ & Breast & Bone Only & $1-3$ & 0 & $4-7$ & $0.92(0.86-0.98)$ & $0.85(0.75 .0 .95)$ & $0.73(0.58-0.91)$ & \\
\hline 20 & $>50$ & Breast & Bone Only & 1.3 & 0 & $8-10$ & $0.93(0.89-0.99)$ & $0.88(0.79-0.97)$ & $0.78(0.64-0.94)$ & \\
\hline 21 & $>50$ & Breast & Bone Only & $1-3$ & $1-3$ & 0 & $0.94(0.91-0.97)$ & $0.88(083-094)$ & $0.79(0.70-0.89)$ & \\
\hline 22 & $>50$ & Breast & Bone Only & $1-3$ & 1.3 & $1-3$ & $0.92(0.88-0.96)$ & $0.85(0.78-0.92)$ & $0.73(0.63-0.85)$ & \\
\hline 23 & $>50$ & Breast & Bone Only & $1-3$ & $1-3$ & $4-7$ & $0.90(085-0.95)$ & $0.81(0.73-0.91)$ & $0.67(0.55-0.82)$ & \\
\hline 24 & $>50$ & Breast & Bone Only & $1-3$ & 1.3 & $8-10$ & $0.92(0.87-0.97)$ & $0.85(0.77-0.94)$ & $0.73(0.60-0.88)$ & \\
\hline 25 & $>50$ & Breast & Bone Only & $1-3$ & $4-7$ & 0 & $0.92(0.88-0.96)$ & $0.85(0.78-0.92)$ & $0.73(0.62-0.85)$ & \\
\hline 26 & $>50$ & Breast & Bone Only & $1-3$ & 4.7 & $1-3$ & $0.90(0.85-0.94)$ & $0.81(0.73-0.89)$ & $0.66(0.55-0.80)$ & \\
\hline 27 & $>50$ & Breast & Bone Only & 1.3 & 4.7 & 4.7 & $0.87(0.81-0.93)$ & $0.76(0.66-0.87)$ & $0.59(0.46-0.76)$ & $70(34-)$ \\
\hline 28 & $>50$ & Breast & Bone Only & $1-3$ & 4.7 & $8-10$ & $0.89(0.83-0.96)$ & $0.80(0.70-0.91)$ & $0.66(0.51-0.84)$ & $93(35-)$ \\
\hline 29 & $>50$ & Breast & Bone Only & $1-3$ & $8-10$ & 0 & $0.91(0.86-0.96)$ & $0.83(0.75-0.92)$ & $0.70(0.58 \cdot 0.86)$ & \\
\hline 30 & $>50$ & Breast & Bone Only & $1-3$ & $8-10$ & $1-3$ & $0.88(0.83-0.95)$ & $0.79(0.69-0.89)$ & $0.63(0.50-0.80)$ & $83(36 \cdot)$ \\
\hline 31 & $>50$ & Breas! & Bone Only & $1-3$ & $8 \cdot 10$ & 4.7 & $0.85(0.78-0.93)$ & $0.74(0.62-0.87)$ & $0.56(0.41-0.76)$ & $62(27-)$ \\
\hline 32 & $>50$ & Breast & Bone Only & $1-3$ & $8-10$ & $8 \cdot 10$ & $0.88(0.82-0.95)$ & $0.78(0.68-0.91)$ & $0.63(0.48-0.82)$ & $83(30-)$ \\
\hline
\end{tabular}




\section{Appendix 4}

\section{Prognostic Index/ Nomogram: Predicted Survival Probability}

\begin{tabular}{|c|c|c|c|c|c|c|c|c|c|c|}
\hline Scenario & $\begin{array}{l}\text { KPS } \\
\text { Score }\end{array}$ & $\begin{array}{l}\text { Primary Cancer } \\
\text { Site }\end{array}$ & $\begin{array}{c}\text { Site of } \\
\text { Metastases }\end{array}$ & $\begin{array}{l}\text { Appelite } \\
\text { Score }\end{array}$ & $\begin{array}{l}\text { Fatigue } \\
\text { Score }\end{array}$ & $\begin{array}{l}\text { Shortness of } \\
\text { Breath Score }\end{array}$ & $\begin{array}{c}\text { Predicted Survival } \\
\text { Probability at } 3 \text { months } \\
(95 \% \mathrm{Cl})\end{array}$ & $\begin{array}{c}\text { Predicted Survival } \\
\text { Probability at } 6 \text { months } \\
\text { (95\% Cl) }\end{array}$ & $\begin{array}{l}\text { Predicted Survival } \\
\text { Probability at } 1 \text { year } \\
(95 \% \mathrm{Cl})\end{array}$ & $\begin{array}{l}\text { Median } \\
\text { Survival in } \\
\text { weeks } \\
(95 \% \mathrm{Cl})\end{array}$ \\
\hline 33 & $>50$ & Breast & Bone Only & 4.7 & 0 & 0 & $0.95(0.92-0.98)$ & $0.90(0.84-0.97)$ & $0.82(0.72-0.94)$ & \\
\hline 34 & $>50$ & Breast & Bone Only & $4-7$ & 0 & 1.3 & $0.94(0.89 \cdot 0.98)$ & $0.88(0.80-0.96)$ & $0.78(0.66-0.92)$ & \\
\hline 35 & $>50$ & Breast & Bone Only & 4.7 & 0 & $4 \cdot 7$ & $0.92(0.86-0.98)$ & $0.85(0.75-0.95)$ & $0.72(0.58-0.91)$ & \\
\hline 36 & $>50$ & Breast & Bone Only & $4-7$ & 0 & $8 \cdot 10$ & $0.93(0.88-0.99)$ & $0.87(0.79-0.97)$ & $0.77(0.64-0.94)$ & \\
\hline 37 & $>50$ & Breast & Bone Only & 4.7 & 1.3 & 0 & $0.94(0.91-0.97)$ & $0.88(0.83-0.94)$ & $0.79(0.70-0.88)$ & \\
\hline 38 & $>50$ & Breast & Bone Only & 4.7 & $1-3$ & 1.3 & $0.92(0.88-0.96)$ & $0.85(0.78-0.92)$ & $0.73(0.63-0.85)$ & \\
\hline 39 & $>50$ & Breas! & Bone Only & $4-7$ & $1-3$ & $4-7$ & $0.90(0.85-0.95)$ & $0.81(0.73-0.90)$ & $0.67(0.55-0.82)$ & \\
\hline 40 & $>50$ & Breast & Bone Only & $4-7$ & $1-3$ & $8-10$ & $0.92(0.87 \cdot 0.97)$ & $0.85(0.77-0.93)$ & $0.72(0.60-0.87)$ & \\
\hline 41 & $>50$ & Breast & Bone Only & $4-7$ & $4-7$ & 0 & $0.92(0.88-0.96)$ & $0.85(0.78-0.92)$ & $0.73(0.62-0.85)$ & \\
\hline 42 & $>50$ & Breast & Bone Only & $4-7$ & 4.7 & $1-3$ & $0.90(0.85-0.94)$ & $0.81(0.73-0.89)$ & $0.66(0.55-0.79)$ & $93(51 \cdot)$ \\
\hline 43 & $>50$ & Breast & Bone Only & $4-7$ & 4.7 & $4 \cdot 7$ & $0.87(0.81-0.93)$ & $0.76(0.66-0.87)$ & $0.59(0.46-0.75)$ & $70(34-)$ \\
\hline 44 & $>50$ & Breast & Bone Only & 4.7 & $4-7$ & $8-10$ & $0.89(0.83-0.95)$ & $0.80(0.70-0.91)$ & $0.65(0.51-0.83)$ & $93(36-)$ \\
\hline 45 & $>50$ & Breast & Bone Only & $4-7$ & $8-10$ & 0 & $0.91(0.86-0.96)$ & $0.83(0.75-0.92)$ & $0.70(0.58-0.84)$ & \\
\hline 46 & $>50$ & Breast & Bone Only & $4-7$ & $8-10$ & $1-3$ & $0.88(0.83-0.94)$ & $0.79(0.70-0.88)$ & $0.63(0.51-0.78)$ & $83(40-)$ \\
\hline 47 & $>50$ & Breast & Bone Only & 4.7 & $8-10$ & $4 \cdot 7$ & $0.85(0.79-0.93)$ & $0.73(0.63-0.86)$ & $0.55(0.41-0.74)$ & $62(29-)$ \\
\hline 48 & $>50$ & Breas! & Bone Only & $4-7$ & $8-10$ & $8-10$ & $0.88(0.82-0.95)$ & $0.78(0.68-0.90)$ & $0.62(0.48-0.81)$ & $83(34-)$ \\
\hline 49 & $>50$ & Breast & Bone Only & $8-10$ & 0 & 0 & $0.91(0.86 \cdot 0.98)$ & $0.84(0.74-0.95)$ & $0.71(0.56-0.90)$ & \\
\hline 50 & $>50$ & Breast & Bone Only & $8-10$ & 0 & $1-3$ & $0.89(0.82-0.97)$ & $0.80(0.67-0.94)$ & $0.65(0.47-0.88)$ & $88(22-)$ \\
\hline 51 & $>50$ & Breast & Bone Only & $8-10$ & 0 & 4.7 & $0.86(0.77-0.96)$ & $0.75(0.60-0.92)$ & $0.57(0.38-0.86)$ & $63(17-)$ \\
\hline 52 & $>50$ & Breast & Bone Only & $8 \cdot 10$ & 0 & $8-10$ & $0.89(0.81 \cdot 0.98)$ & $0.79(0.66 \cdot 0.95)$ & $0.64(0.45-0.91)$ & $84(16-)$ \\
\hline 53 & $>50$ & Breast & Bone Only & $8 \cdot 10$ & $1 \cdot 3$ & 0 & $0.89(0.84 .0 .95)$ & $0.80(0.71-0.91)$ & $0.65(0.52-0.83)$ & $93(36 \cdot)$ \\
\hline 54 & $>50$ & Breast & Bone Only & $8 \cdot 10$ & $1-3$ & $1-3$ & $0.86(0.80-0.94)$ & $0.75(0.64-0.88)$ & $0.58(0.43-0.78)$ & $66(29-)$ \\
\hline 55 & $>50$ & Breast & Bone Only & $8-10$ & 1.3 & 4.7 & $0.83(0.74-0.92)$ & $0.69(0.56-0.85)$ & $0.49(0.34-0.72)$ & $52(20-84)$ \\
\hline 56 & $>50$ & Breast & Bone Only & $8-10$ & $1-3$ & $8 \cdot 10$ & $0.86(0.78-0.95)$ & $0.75(0.62-0.90)$ & $0.57(0.40-0.81)$ & $63(23-)$ \\
\hline 57 & $>50$ & Breast & Bone Only & $8-10$ & 4.7 & 0 & $086(0.79-0.94)$ & $0.75(0.64-0.88)$ & $0.57(0.42-0.77)$ & $63(28-)$ \\
\hline 58 & $>50$ & Breast & Bone Only & 8.10 & $4-7$ & $1-3$ & $082(0.75-0.91)$ & $0.68(0.57-0.83)$ & $0.48(0.34-0.70)$ & $50(23-80)$ \\
\hline 59 & $>50$ & Breast & Bone Only & $8-10$ & 4.7 & $4-7$ & $078(0.68-0.89)$ & $0.61(0.48-0.79)$ & $0.39(0.24-0.64)$ & $36(17-61)$ \\
\hline 60 & $>50$ & Breast & Bone Only & $8 \cdot 10$ & 4.7 & $8-10$ & $082(0.73-0.93)$ & $0.68(0.54-0.86)$ & $0.48(0.30-0.75)$ & $49(18-83)$ \\
\hline 61 & $>50$ & Breast & Bone Only & $8 \cdot 10$ & $8-10$ & 0 & $0.85(0.77-0.93)$ & $0.72(0.61-0.86)$ & $0.54(0.39-0.75)$ & $60(26-)$ \\
\hline 62 & $>50$ & Breast & Bone Only & 8.10 & 8-10 & $1-3$ & $0.81(0.72-0.90)$ & $0.66(0.53-0.81)$ & $0.45(0.30-0.66)$ & $41(20-70)$ \\
\hline 63 & $>50$ & Breast & Bone Only & $8-10$ & $8 \cdot 10$ & $4-7$ & $0.76(0.66 \cdot 0.87)$ & $0.58(044-0.76)$ & $0.35(0.21-0.59)$ & $34(16-52)$ \\
\hline 64 & $>50$ & Breast & Bone Only & $8-10$ & $8-10$ & $8 \cdot 10$ & $0.80(0.71-0.91)$ & $0.65(0.51-0.82)$ & $0.44(0.28-0.69)$ & $41(19-70)$ \\
\hline
\end{tabular}


Appendix 4

Prognostic Index/ Nomogram: Predicted Survival Probability

\begin{tabular}{|c|c|c|c|c|c|c|c|c|c|c|}
\hline Scenario & $\begin{array}{l}\text { KPS } \\
\text { Score }\end{array}$ & $\begin{array}{c}\text { Primary Cancer } \\
\text { Site }\end{array}$ & $\begin{array}{c}\text { Site of } \\
\text { Metastases }\end{array}$ & $\begin{array}{l}\text { Appetite } \\
\text { Score }\end{array}$ & $\begin{array}{l}\text { Fatigue } \\
\text { Score }\end{array}$ & $\begin{array}{l}\text { Shortness of } \\
\text { Breath Score }\end{array}$ & $\begin{array}{c}\text { Predicted Survival } \\
\text { Probability at } 3 \text { months } \\
(95 \% \mathrm{Cl})\end{array}$ & $\begin{array}{c}\text { Predicled Survival } \\
\text { Probability al } 6 \text { months } \\
\text { (95\% CI) }\end{array}$ & $\begin{array}{c}\text { Predicted Survival } \\
\text { Probability at } 1 \text { year } \\
\text { (95\% CI) }\end{array}$ & $\begin{array}{l}\text { Median } \\
\text { Survival in } \\
\text { weeks } \\
(95 \% \mathrm{Cl})\end{array}$ \\
\hline 65 & $>50$ & Breast & Others & 0 & 0 & 0 & $0.90(0.84-0.96)$ & $0.81(0.71-0.92)$ & $0.67(0.53-0.86)$ & \\
\hline 66 & $>50$ & Breast & Others & 0 & 0 & 1.3 & $0.87(0.79-0.96)$ & $0.76(0.64-0.92)$ & $0.60(0.42-0.64)$ & $71(21-)$ \\
\hline 67 & $>50$ & Breast & Others & 0 & 0 & 4.7 & $0.84(0.74-0.95)$ & $0.71(0.56-0.90)$ & $0.52(0.33-0.81)$ & $55(16-)$ \\
\hline 68 & $>50$ & Breast & Others & 0 & 0 & 8.10 & $0.87(0.78-0.97)$ & $0.76(0.62 .0 .93)$ & $0.59(0.40-0.87)$ & $70(16-)$ \\
\hline 69 & $>50$ & Breast & Others & 0 & $1-3$ & 0 & $0.88(0.82-0.93)$ & $0.77(0.68-0.87)$ & $0.61(0.48-0.76)$ & 75 (36-) \\
\hline 70 & $>50$ & Breast & Others & 0 & $1-3$ & $1-3$ & $0.84(0.77-0.92)$ & $0.71(0.60-0.85)$ & $0.52(0.38-0.72)$ & $59(27-93)$ \\
\hline 71 & $>50$ & Breast & Others & 0 & $1-3$ & 4.7 & $0.80(0.71-0.90)$ & $0.65(0.52-0.81)$ & $0.43(0.28-0.67)$ & $40(19-69)$ \\
\hline 72 & $>50$ & Breast & Others & 0 & $1-3$ & $8-10$ & $0.84(0.75-0.93)$ & $0.71(0.58-0.87)$ & $0.52(0.35-0.76)$ & $55(20-93)$ \\
\hline 73 & $>50$ & Breast & Others & 0 & $4-7$ & 0 & $0.84(0.77-0.92)$ & $0.71(0.60-0.84)$ & $0.52(0.38-0.71)$ & $55(27-84)$ \\
\hline 74 & $>50$ & Breasi & Others & 0 & $4-7$ & $1-3$ & $0.80(0.71-0.89)$ & $0.64(0.51-0.80)$ & $0.43(0.28-0.64)$ & $39(20-63)$ \\
\hline 75 & $>50$ & Breası & Others & 0 & $4-7$ & 4.7 & $0.75(0.64-0.87)$ & $0.56(0.42-0.76)$ & $0.33(0.19-0.59)$ & $31(14-51)$ \\
\hline 76 & $>50$ & Breas! & Others & 0 & $4-7$ & $8 \cdot 10$ & $0.79(0.69-0.91)$ & $0.63(0.48-0.83)$ & $0.42(0.25 \cdot 0.70)$ & $38(15.69)$ \\
\hline 77 & $>50$ & Breas! & Others & 0 & $8-10$ & 0 & $0.82(0.74 .0 .91)$ & $0.68(0.56-0.83)$ & $0.48(0.34-0.69)$ & $50(23-80)$ \\
\hline 78 & $>50$ & Breast & Others & 0 & $8 \cdot 10$ & $1+3$ & $0.78(0.68 \cdot 0.88)$ & $0.61(0.47-0.78)$ & $0.39(0.24-0.62)$ & $35(18-60)$ \\
\hline 79 & $>50$ & Breast & Others & 0 & $8-10$ & 4.7 & $0.72(0.61-0.86)$ & $0.53(0.38-0.74)$ & $0.29(0.16-0.56)$ & $27(13-41)$ \\
\hline 80 & $>50$ & Breast & Olners & 0 & 8.10 & $8-10$ & $0.77(0.66-0.90)$ & $0.60(0.45-0.80)$ & $0.38(0.22-0.65)$ & $35(15-61)$ \\
\hline 81 & $>50$ & Breast & Others & 1.3 & 0 & 0 & $0.90(0.84-0.96)$ & $0.81(0.72-0.92)$ & $0.67(0.53-0.85)$ & \\
\hline 82 & $>50$ & Breast & Others & $1-3$ & 0 & $1-3$ & $0.87(0.80-0.95)$ & $0.76(0.65-0.91)$ & $0.60(0.44-0.82)$ & $72(26-)$ \\
\hline 83 & $>50$ & Breast & Others & $1-3$ & 0 & $4-7$ & $0.84(0.75-0.94)$ & $0.71(0.57-0.89)$ & $0.52(0.34-0.79)$ & $55(19 \cdot)$ \\
\hline 84 & $>50$ & Breas! & Others & $1-3$ & 0 & $8-10$ & $0.87(0.78-0.96)$ & $0.76(0.62-0.93)$ & $0.59(0.41-0.86)$ & $70(19-)$ \\
\hline 85 & $>50$ & Breast & Others & $1-3$ & 1.3 & 0 & $0.88(0.82-0.93)$ & $0.77(0.68-0.87)$ & $0.61(0.49-0.76)$ & $80(39-)$ \\
\hline 86 & $>50$ & Breas! & Others & $1-3$ & $1-3$ & $1-3$ & $0.84(0.78-0.91)$ & $0.71(0.61-0.83)$ & $0.53(0.40-0.69)$ & $59(30-84)$ \\
\hline 87 & $>50$ & Breast & Others & $1 \cdot 3$ & $1-3$ & 4.7 & $0.80(0.72-0.89)$ & $0.65(0.53-0.80)$ & $0.44(0.30-0.64)$ & $41(21-63)$ \\
\hline 88 & $>50$ & Breast & Others & $1-3$ & $1-3$ & $8-10$ & $0.84(0.76-0.93)$ & $0.71(0.59-0.86)$ & $0.52(0.36-0.74)$ & 55 (24-93) \\
\hline 89 & $>50$ & Breast & Others & $1-3$ & $4-7$ & 0 & $0.84(0.77-0.91)$ & $0.71(0.61-0.83)$ & $0.52(0.39-0.70)$ & $58(29-84)$ \\
\hline 90 & $>50$ & Breast & Others & $1-3$ & 4.7 & $1-3$ & $0.80(0.72-0.88)$ & $0.64(0.53-0.77)$ & $0.43(0.30-0.60)$ & $39(23-62)$ \\
\hline 91 & $>50$ & Breast & Others & $1-3$ & 4.7 & $4-7$ & $0.75(0.65 .0 .85)$ & $0.57(0.44-0.73)$ & $0.34(0.21-0.54)$ & $31(17-48)$ \\
\hline 92 & $>50$ & Breast & Others & $1-3$ & $4-7$ & $8-10$ & $0.79(0.70-0.90)$ & $0.63(0.50-0.81)$ & $0.42(0.26-0.66)$ & $39(18-63)$ \\
\hline 93 & $>50$ & Breast & Others & $1-3$ & $8-10$ & 0 & $0.82(0.74-0.91)$ & $0.68(0.56-0.83)$ & $0.48(0.34-0.69)$ & $50(23-80)$ \\
\hline 94 & $>50$ & Breast & Others & 1.3 & $8 \cdot 10$ & $1-3$ & $0.78(0.69 .0 .88)$ & $0.61(0.49 \cdot 0.77)$ & $0.39(0.25-0.59)$ & $35(19-58)$ \\
\hline 95 & $>50$ & Breas! & Others & $1-3$ & $8-10$ & $4-7$ & $0.72(0.61-085)$ & $0.53(0.39-0.72)$ & $0.30(0.17-0.53)$ & $28(14-41)$ \\
\hline 96 & $>50$ & Breast & Oiners & $1-3$ & $8 \cdot 10$ & $8-10$ & $0.77(0.67-089)$ & $0.60(0.46-0.79)$ & $0.38(0.23-0.63)$ & $35(16-60)$ \\
\hline
\end{tabular}


Appendix 4

Prognostic Index/ Nomogram: Predicted Survival Probability

\begin{tabular}{|c|c|c|c|c|c|c|c|c|c|c|}
\hline Scenario & $\begin{array}{l}\text { KPS } \\
\text { Score }\end{array}$ & $\begin{array}{l}\text { Primary Cancer } \\
\text { Site }\end{array}$ & $\begin{array}{c}\text { Site of } \\
\text { Metastases }\end{array}$ & $\begin{array}{l}\text { Appetite } \\
\text { Score }\end{array}$ & $\begin{array}{l}\text { Fatigue } \\
\text { Score }\end{array}$ & $\begin{array}{l}\text { Shortness of } \\
\text { Breath Score }\end{array}$ & $\begin{array}{l}\text { Predicted Survival } \\
\text { Probability at } 3 \text { months } \\
(95 \% \mathrm{Cl})\end{array}$ & $\begin{array}{c}\text { Predicled Survival } \\
\text { Probability at } 6 \text { months } \\
(95 \% \mathrm{Cl})\end{array}$ & $\begin{array}{l}\text { Predicted Survival } \\
\text { Probability at } 1 \text { year } \\
(95 \% \text { Cl) }\end{array}$ & $\begin{array}{l}\text { Median } \\
\text { Survival in } \\
\text { weeks } \\
(95 \% \mathrm{Cl})\end{array}$ \\
\hline 97 & $>50$ & Breast & Olhers & 4.7 & 0 & 0 & $0.90(0.84-0.96)$ & $0.81(0.71-0.92)$ & $0.67(0.53-0.86)$ & \\
\hline 98 & $>50$ & Breast & Others & 4.7 & 0 & $1-3$ & $0.87(0.80-0.95)$ & $0.76(0.64-0.91)$ & $0.60(0.43-0.83)$ & $71(25-)$ \\
\hline 99 & $>50$ & Breast & Others & $4-7$ & 0 & $4-7$ & $0.84(0.74-0.94)$ & $0.71(0.56-0.89)$ & $0.51(0.33-0.79)$ & $54(18-)$ \\
\hline 100 & $>50$ & Breast & Others & $4-7$ & 0 & $8 \cdot 10$ & $0.87(0.78 \cdot 0.96)$ & $0.76(0.62-0.93)$ & $0.59(0.40-0.86)$ & $70(19-)$ \\
\hline 101 & $>50$ & Breast & Others & 4.7 & $1-3$ & 0 & $0.87(0.82-0.93)$ & $0.77(0.69-0.86)$ & $0.61(0.49-0.75)$ & 75 (39-) \\
\hline 102 & $>50$ & Breast & Others & $4-7$ & $1-3$ & 1.3 & $0.84(0.78-0.91)$ & $0.71(0.62-0.82)$ & $0.52(0.40-0.68)$ & $58(30.83)$ \\
\hline 103 & $>50$ & Breast & Olhers & 4.7 & $1-3$ & 4.7 & $0.80(0.72-0.89)$ & $0.65(0.53-0.79)$ & $0.43(0.30-0.63)$ & $40(21-62)$ \\
\hline 104 & $>50$ & Breast & Others & 4.7 & $1-3$ & $8-10$ & $0.84(0.76 \cdot 0.92)$ & $0.71(0.59-0.85)$ & $0.51(0.36-0.73)$ & $54(25-88)$ \\
\hline 105 & $>50$ & Breast & Others & $4-7$ & $4 \cdot 7$ & 0 & $0.84(0.77-0.91)$ & $0.71(0.61-0.82)$ & $0.52(0.39-0.68)$ & $55(30-83)$ \\
\hline 106 & $>50$ & Breast & Others & 4.7 & $4-7$ & 1.3 & $0.80(0.73-0.87)$ & $0.64(0.54-0.76)$ & $0.42(9.31-0.58)$ & $39(25-60)$ \\
\hline 107 & $>50$ & Breast & Others & $4-7$ & $4-7$ & $4-7$ & $0.74(0.66 \cdot 0.85)$ & $0.56(0.44-0.72)$ & $0.33(0.21-0.52)$ & $31(18-47)$ \\
\hline 108 & $>50$ & Breast & Others & $4-7$ & $4-7$ & $8-10$ & $0.79(0.70-0.90)$ & $0.63(0.50-0.80)$ & $0.42(0.27-0.65)$ & $38(19-62)$ \\
\hline 109 & $>50$ & Breast & Others & 4.7 & $8 \cdot 10$ & 0 & $0.82(0.75-0.90)$ & $0.68(0.57-0.81)$ & $0.48(0.35 \cdot 0.66)$ & $49(26-72)$ \\
\hline 110 & $>50$ & Breast & Others & $4-7$ & $8-10$ & $1-3$ & $0.77(0.70-0.86)$ & $0.61(0.49-0.75)$ & $0.39(0.26-0.56)$ & $35(20-53)$ \\
\hline 111 & $>50$ & Breast & Others & 4.7 & 8.10 & $4-7$ & $0.72(0.62-0.83)$ & $0.53(0.40-0.70)$ & $0.29(0.17-0.50)$ & $27(15-39)$ \\
\hline 112 & $>50$ & Breast & Others & 4.7 & $8 \cdot 10$ & $8 \cdot 10$ & $0.77(0.68 \cdot 0.88)$ & $0.60(0.47-0.77)$ & $0.38(0.24-0.60)$ & $35(19-59)$ \\
\hline 113 & $>50$ & Breast & Others & $8-10$ & 0 & 0 & $0.83(0.73 .0 .94)$ & $0.69(0.54 \cdot 0.89)$ & $0.50(0.31-0.79)$ & $52(16-93)$ \\
\hline 114 & $>50$ & Breast & Others & $8-10$ & 0 & $1-3$ & $0.79(0.66 \cdot 0.93)$ & $0.62(0.45-0.87)$ & $0.40(0.22-0.76)$ & $38(12-70)$ \\
\hline 115 & $>50$ & Breas! & Others & $8-10$ & 0 & $4 \cdot 7$ & $0.73(0.59-0.91)$ & $0.54(0.36-0.83)$ & $0.31(0.14-0.70)$ & $29(9-53)$ \\
\hline 116 & $>50$ & Breast & Others & $8 \cdot 10$ & 0 & $8-10$ & $0.78(0.65-0.94)$ & $0.62(0.43-0.89)$ & $0.40(0.20-0.80)$ & $36(9-70)$ \\
\hline 117 & $>50$ & Breast & Others & $8-10$ & $1-3$ & 0 & $0.79(0.70-0.90)$ & $0.63(0.50-0.81)$ & $0.42(0.26-0.66)$ & $38(18-63)$ \\
\hline 118 & $>50$ & Breast & Others & $8-10$ & $1-3$ & $1-3$ & $0.74(0.63-0.87)$ & $0.55(0.40-0.76)$ & $0.32(0.18-0.58)$ & $30(14-49)$ \\
\hline 119 & $>50$ & Breast & Others & $8-10$ & $1-3$ & $4-7$ & $0.68(0.55-0.83)$ & $0.47(0.31-0.70)$ & $0.23(0.11-0.50)$ & $22(11-35)$ \\
\hline 120 & $>50$ & Breast & Others & $8-10$ & $1-3$ & $8-10$ & $0.73(0.61-0.88)$ & $0.54(0.38-0.78)$ & $0.31(0.16-0.62)$ & $29(12-50)$ \\
\hline 121 & $>50$ & Breast & Others & $8-10$ & $4-7$ & 0 & $0.73(0.62-0.86)$ & $0.55(0.40-0.75)$ & $0.32(0.17-0.57)$ & $29(14-48)$ \\
\hline 122 & $>50$ & Breas! & Others & $8-10$ & $4-7$ & $1-3$ & $067(0.55-0.82)$ & $0.46(0.31-0.67)$ & $0.22(0.11-0.46)$ & $21(12-34)$ \\
\hline 123 & $>50$ & Breast & Others & $8-10$ & $4-7$ & $4-7$ & $0.60(0.46-0.77)$ & $0.37(0.22-0.60)$ & $0.15(0.06-0.38)$ & $17(9-26)$ \\
\hline 124 & $>50$ & Breast & Others & $8-10$ & $4-7$ & $8 \cdot 10$ & $066(0.52-0.84)$ & $0.45(0.28-0.71)$ & $0.22(0.09-0.52)$ & $21(10.35)$ \\
\hline 125 & $>50$ & Breast & Others & $8-10$ & 8-10 & 0 & $0.71(0.60-0.84)$ & $0.51(0.37-0.71)$ & $0.28(0.15-0.52)$ & $26(14-39)$ \\
\hline 126 & $>50$ & Breast & Others & $8-10$ & 8.10 & 1.3 & $0.64(0.52-0.79)$ & $0.42(0.28 .0 .62)$ & $0.19(0.09-0.40)$ & $19(11-30)$ \\
\hline 127 & $>50$ & Breast & Olhers & $8-10$ & $8-10$ & 4.7 & $056(0.43-0.73)$ & $0.33(0.20-0.54)$ & $0.12(0.04 \cdot 0.31)$ & $16(9-23)$ \\
\hline 128 & $>50$ & Breast & Others & $8-10$ & 8.10 & $8-10$ & $063(050-080)$ & $0.41(026-0.64)$ & $0.18(0.08-0.43)$ & $19(11-31)$ \\
\hline
\end{tabular}


Appendix 4

Prognostic Index/ Nomogram: Predicted Survival Probability

\begin{tabular}{|c|c|c|c|c|c|c|c|c|c|c|}
\hline Scenario & $\begin{array}{l}\text { KPS } \\
\text { Score }\end{array}$ & $\begin{array}{c}\text { Primary Cancer } \\
\text { Site }\end{array}$ & $\begin{array}{c}\text { Site of } \\
\text { Metastases }\end{array}$ & $\begin{array}{l}\text { Appetite } \\
\text { Score }\end{array}$ & $\begin{array}{c}\text { Fatigue } \\
\text { Score }\end{array}$ & $\begin{array}{l}\text { Shortness of } \\
\text { Breath Score }\end{array}$ & $\begin{array}{l}\text { Predicted Survival } \\
\text { Probability at } 3 \text { months } \\
(95 \% \mathrm{Cl})\end{array}$ & $\begin{array}{l}\text { Predicted Survival } \\
\text { Probability at } 6 \text { months } \\
(95 \% \mathrm{Cl})\end{array}$ & $\begin{array}{l}\text { Predicted Survival } \\
\text { Probability at } 1 \text { year } \\
\text { (95\% Cl) }\end{array}$ & $\begin{array}{l}\text { Median } \\
\text { Survival in } \\
\text { weeks } \\
(95 \% \mathrm{Cl})\end{array}$ \\
\hline 129 & $>50$ & Prostate & Bone Only & 0 & 0 & 0 & $0.91(0.85-0.96)$ & $0.82(0.73-0.93)$ & $0.69(0.55-0.87)$ & \\
\hline 130 & $>50$ & Prostate & Bone Only & 0 & 0 & $1-3$ & $0.88(0.80 \cdot 0.96)$ & $0.78(0.65 \cdot 0.92)$ & $0.62(0.44-0.86)$ & $80(22)$. \\
\hline 131 & $>50$ & Prostale & Bone Only & 0 & 0 & 4-7 & $0.85(0.75-0.95)$ & $0.72(0.57-0.91)$ & $0.54(0.35-0.83)$ & $60(16-)$ \\
\hline 132 & $>50$ & Prostate & Bone Only & 0 & 0 & $8-10$ & $0.88(0.79-0.97)$ & $0.77(0.63-0.95)$ & $0.61(0.41-0.90)$ & $80(16-)$ \\
\hline 133 & $>50$ & Prostale & Bone Only & 0 & 1.3 & 0 & $0.88(0.83-0.94)$ & $0.78(0.70-0.87)$ & $0.63(0.51-0.77)$ & $83(41-)$ \\
\hline 134 & $>50$ & Prostate & Bone Only & 0 & $1-3$ & $1-3$ & $0.85(0.78-0.92)$ & $0.73(0.62-0.85)$ & $0.54(0.40-0.73)$ & $61(29-)$ \\
\hline 135 & $>50$ & Prostale & Bone Only & 0 & $1-3$ & $4-7$ & $0.81(0.73-0.91)$ & $0.66(0.54-0.82)$ & $0.46(0.31-0.68)$ & $44(20-71)$ \\
\hline 136 & $>50$ & Prostate & Bone Only & 0 & 1.3 & $8-10$ & $0.85(0.76-0.94)$ & $0.72(0.59-0.88)$ & $0.54(0.37-0.78)$ & $60(20-)$ \\
\hline 137 & $>50$ & Prostate & Bone Only & 0 & $4-7$ & 0 & $0.85(0.79-0.91)$ & $0.72(0.63-0.83)$ & $0.54(0.41-0.70)$ & $60(31-88)$ \\
\hline 138 & $>50$ & Prostate & Bone Only & 0 & $4-7$ & $1-3$ & $0.81(0.73-0.89)$ & $0.66(0.54-0.80)$ & $0.45(0.31-0.64)$ & $41(22-66)$ \\
\hline 139 & $>50$ & Prostate & Bone Only & 0 & $4-7$ & $4-7$ & $0.76(0.66-0.87)$ & $0.58(0.45-0.76)$ & $0.36(0.21-0.59)$ & $34(16.52)$ \\
\hline 140 & $>50$ & Prostate & Bone Only & 0 & $4-7$ & $8-10$ & $0.80(0.70-0.92)$ & $0.65(0.50-0.84)$ & $0.44(0.27-0.72)$ & $41(16-72)$ \\
\hline 141 & $>50$ & Prostate & Bone Only & 0 & $8-10$ & 0 & $0.83(0.76-0.91)$ & $0.70(0.58-0.84)$ & $0.50(0.36-0.70)$ & $52(25-83)$ \\
\hline 142 & $>50$ & Prostate & Bone Only & 0 & $8-10$ & $1 \cdot 3$ & $0.79(0.69-0.89)$ & $0.63(0.49-0.80)$ & $0.41(0.26-0.65)$ & $38(19-62)$ \\
\hline 143 & $>50$ & Prostate & Bone Only & 0 & $8-10$ & $4-7$ & $0.74(0.62-0.87)$ & $0.55(0.40-0.76)$ & $0.32(0.17-0.59)$ & $29(13-49)$ \\
\hline 144 & $>50$ & Prostate & Bone Only & 0 & $8-10$ & $8-10$ & $0.78(0.67-0.91)$ & $0.62(0.46-0.83)$ & $0.40(0.23-0.69)$ & $37(14-63)$ \\
\hline 145 & $>50$ & Prostate & Bone Only & 1.3 & 0 & 0 & $0.91(0.85-0.97)$ & $0.82(0.73-0.93)$ & $0.69(0.54-0.87)$ & \\
\hline 146 & $>50$ & Prostate & Bone Only & 1.3 & 0 & 1.3 & $0.88(0.80-0.96)$ & $0.78(0.65-0.92)$ & $0.62(0.45-0.85)$ & $80(24-)$ \\
\hline 147 & $>50$ & Prostate & Bone Only & 1.3 & 0 & 4.7 & $0.85(0.75-0.95)$ & $0.72(0.58-0.91)$ & $0.54(0.35-0.83)$ & $60(17-)$ \\
\hline 148 & $>50$ & Prostate & Bone Oniy & 1.3 & 0 & $8-10$ & $0.88(0.79-0.97)$ & $0.77(0.63-0.94)$ & $0.61(0.42-0.89)$ & $80(16-)$ \\
\hline 149 & $>50$ & Prostate & Bone Only & 1.3 & 1.3 & 0 & $0.88(0.83 \cdot 0.94)$ & $0.78(0.70 .0 .88)$ & $0.63(0.50-0.78)$ & $83(38-)$ \\
\hline 150 & $>50$ & Prostate & Bone Only & 1.3 & 1.3 & $1-3$ & $0.85(0.78-0.92)$ & $0.73(0.63-0.85)$ & $0.55(0.41-0.73)$ & $62(30-)$ \\
\hline 151 & $>50$ & Prostate & Bone Only & $1-3$ & $1-3$ & $4 \cdot 7$ & $0.81(0.73-0.91)$ & $0.67(0.54-0.82)$ & $0.46(0.31-0.68)$ & $45(20-71)$ \\
\hline 152 & $>50$ & Prostate & Bone Only & 1.3 & 1.3 & $8-10$ & $0.85(0.77-0.94)$ & $0.72(0.60-0.88)$ & $0.54(0.37-0.78)$ & $60(21-)$ \\
\hline 153 & $>50$ & Prostate & Bone Only & $1-3$ & 4.7 & 0 & $0.85(0.78-0.92)$ & $0.73(0.63-0.84)$ & $0.54(0.41-0.71)$ & $61(31-93)$ \\
\hline 154 & $>50$ & Prostate & Bone Only & 1.3 & 4.7 & 1.3 & $0.81(0.73-089)$ & $0.66(0.55 .0 .79)$ & $0.45(0.32-0.63)$ & $41(25-63)$ \\
\hline 155 & $>50$ & Proslate & Bone Only & 1.3 & 4.7 & 4.7 & $076(0.67-0.87)$ & $0.59(0.46-0.75)$ & $0.36(0.22-0.57)$ & $34(18-52)$ \\
\hline 156 & $>50$ & Prostate & Bone Only & 1.3 & 4.7 & $8-10$ & $0.80(0.71-0.91)$ & $0.65(0.51-0.83)$ & $0.44(0.28-0.70)$ & $41(18-71)$ \\
\hline 157 & $>50$ & Prostate & Bone Only & $1-3$ & $8 \cdot 10$ & 0 & $0.83(0.75-092)$ & $0.70(0.58-0.85)$ & $0.50(0.35-0.72)$ & $53(23-84)$ \\
\hline 158 & $>50$ & Prostate & Bone Only & 1.3 & 8.10 & 1.3 & $0.79(0.70-0.89)$ & $0.63(0.50-0.80)$ & $0.41(0.26-0.64)$ & $38(19.62)$ \\
\hline 159 & $>50$ & Prostate & Bone Only & 1.3 & $8-10$ & $4-7$ & $0.74(0.62-0.87)$ & $0.55(0.40-0.76)$ & $0.32(0.17-0.58)$ & $30(14-49)$ \\
\hline 160 & $>50$ & Prostate & Bone Only & 1.3 & $8-10$ & $8-10$ & $0.78(0.68 .091)$ & $0.62(047-0.83)$ & $0.40(0.24-0.69)$ & $37(15-63)$ \\
\hline
\end{tabular}


Appendix 4

Prognostic Index/ Nomogram: Predicted Survival Probability

\begin{tabular}{|c|c|c|c|c|c|c|c|c|c|c|}
\hline Scenario & $\begin{array}{l}\text { KPS } \\
\text { Score }\end{array}$ & $\begin{array}{c}\text { Primary Cancer } \\
\text { Site }\end{array}$ & $\begin{array}{c}\text { Site of } \\
\text { Melastases }\end{array}$ & $\begin{array}{l}\text { Appetite } \\
\text { Score }\end{array}$ & $\begin{array}{c}\text { Fatigue } \\
\text { Score }\end{array}$ & $\begin{array}{l}\text { Shortness of } \\
\text { Breath Score }\end{array}$ & $\begin{array}{l}\text { Predicled Survival } \\
\text { Probability at } 3 \text { months } \\
\text { (95\% CI) }\end{array}$ & $\begin{array}{l}\text { Predicted Survival } \\
\text { Probability at } 6 \text { months } \\
(95 \% \mathrm{Cl})\end{array}$ & $\begin{array}{c}\text { Predicted Survival } \\
\text { Probability at } 1 \text { year } \\
\text { (95\% Cl) }\end{array}$ & $\begin{array}{c}\text { Median } \\
\text { Survival in } \\
\text { weeks } \\
(95 \% \mathrm{Cl})\end{array}$ \\
\hline 161 & $>50$ & Prostate & Bone Only & $4-7$ & 0 & 0 & $0.90(0.84-0.97)$ & $0.82(0.72-0.94)$ & $0.69(0.54-0.88)$ & \\
\hline 162 & $>50$ & Prostate & Bone Only & 4.7 & 0 & $1-3$ & $0.88(0.80-0.96)$ & $0.78(0.65 \cdot 0.93)$ & $0.61(0.44-0.86)$ & $80(21 \cdot)$ \\
\hline 163 & $>50$ & Prostate & Bone Only & $4-7$ & 0 & $4-7$ & $0.85(0.75 \cdot 0.96)$ & $0.72(0.57-0.91)$ & $0.54(0.34-0.84)$ & $60(15-)$ \\
\hline 164 & $>50$ & Prostate & Bone Only & $4-7$ & 0 & 8-10 & $0.88(0.79-0.97)$ & $0.77(0.63-0.95)$ & $0.61(0.41-0.90)$ & $75(14-)$ \\
\hline 165 & $>50$ & Prostate & Bone Only & $4-7$ & 1.3 & 0 & $0.88(0.83-0.94)$ & $0.78(0.69-0.88)$ & $0.63(0.50-0.78)$ & $83(39 \cdot)$ \\
\hline 166 & $>50$ & Prostate & Bone Only & $4-7$ & 1.3 & $1-3$ & $0.85(0.78-0.92)$ & $0.73(0.62-0.85)$ & $0.54(0.41-0.72)$ & $61(29 \cdot)$ \\
\hline 167 & $>50$ & Prostate & Bone Only & $4-7$ & $1-3$ & $4 \cdot 7$ & $0.81(0.73-0.91)$ & $0.66(0.54-0.82)$ & $0.46(0.31-0.68)$ & $44(20-71)$ \\
\hline 168 & $>50$ & Proslate & Bone Only & $4-7$ & $1-3$ & $8-10$ & $0.85(0.76-0.94)$ & $0.72(0.59-0.88)$ & $0.54(0.37-0.78)$ & $60(21-)$ \\
\hline 169 & $>50$ & Prostate & Bone Only & $4-7$ & $4-7$ & 0 & $0.85(0.78-0.92)$ & $0.72(0.63-0.84)$ & $0.54(0.41-0.70)$ & $60(31-93)$ \\
\hline 170 & $>50$ & Proslate & Bone Only & $4-7$ & 4.7 & $1-3$ & $0.81(0.73-0.89)$ & $0.66(0.55-0.78)$ & $0.45(0.32-0.62)$ & $41(25-63)$ \\
\hline 171 & $>50$ & Prostate & Bone Only & $4-7$ & 4.7 & $4-7$ & $0.76(0.66-0.87)$ & $0.58(0.45-0.75)$ & $0.36(0.22-0.57)$ & $34(18-52)$ \\
\hline 172 & $>50$ & Proslate & Bone Only & $4-7$ & 4.7 & $8-10$ & $0.80(0.70-0.91)$ & $0.65(0.51-0.83)$ & $0.44(0.28-0.70)$ & $41(18-70)$ \\
\hline 173 & $>50$ & Proslate & Bone Only & $4-7$ & $8-10$ & 0 & $0.83(0.75-0.92)$ & $0.70(0.58-0.84)$ & $0.50(0.36-0.71)$ & $52(25-83)$ \\
\hline 174 & $>50$ & Prostale & Bone Only & 4.7 & $8-10$ & $1-3$ & $0.79(0.70-0.89)$ & $0.63(0.50-0.79)$ & $0.41(0.27-0.63)$ & $38(19-62)$ \\
\hline 175 & $>50$ & Prostate & Bone Only & $4-7$ & $8-10$ & 4.7 & $0.74(0.63-0.86)$ & $0.55(0.40-0.75)$ & $0.32(0.18-0.57)$ & $29(14-48)$ \\
\hline 176 & $>50$ & Prostate & Bone Only & 4.7 & $8-10$ & $8-10$ & $0.78(0.68-0.90)$ & $0.62(0.47-0.82)$ & $0.40(0.24-0.67)$ & $36(15-62)$ \\
\hline 177 & $>50$ & Prostate & Bone Only & $8-10$ & 0 & 0 & $0.84(0.74-0.95)$ & $0.71(0.56-0.90)$ & $0.52(0.33-0.82)$ & $58(16-)$ \\
\hline 178 & $>50$ & Prostate & Bone Only & $8-10$ & 0 & $1-3$ & $0.80(0.67-0.94)$ & $0.64(0.46-0.89)$ & $0.43(0.23-0.79)$ & $39(11-80)$ \\
\hline 179 & $>50$ & Prostate & Bone Only & $8-10$ & 0 & 4.7 & $0.75(0.60-0.93)$ & $0.56(0.37-0.86)$ & $0.34(0.15-0.74)$ & $31(9-60)$ \\
\hline 180 & $>50$ & Prostate & Bone Only & $8-10$ & 0 & 8.10 & $0.79(066.0 .96)$ & $0.63(0.44-0.92)$ & $0.42(0.21-0.84)$ & $39(8-80)$ \\
\hline 181 & $>50$ & Prostate & Bone Only & $8-10$ & $1-3$ & 0 & $0.80(0.71-0.91)$ & $0.65(052-0.82)$ & $0.44(0.28-0.68)$ & $41(19-70)$ \\
\hline 182 & $>50$ & Prostate & Bone Only & $8-10$ & $1-3$ & $1-3$ & $0.75(0.64-0.88)$ & $0.57(0.42-0.78)$ & $0.34(0.19-0.61)$ & $31(14-52)$ \\
\hline 183 & $>50$ & Prostale & Bone Only & $8-10$ & $1-3$ & 4.7 & $0.69(0.57-0.85)$ & $0.49(0.33-0.72)$ & $0.25(0.12-0.54)$ & $25(12.38)$ \\
\hline 184 & $>50$ & Prostale & Bone Only & $8-10$ & 1.3 & 8.10 & $0.75(0.62 .0 .90)$ & $0.56(0.39-0.81)$ & $0.34(0.17-0.67)$ & $31(12-54)$ \\
\hline 185 & $>50$ & Prostale & Bone Only & $8-10$ & $4-7$ & 0 & $0.75(0.65-0.87)$ & $0.57(0.43 \cdot 0.75)$ & $0.34(0.20-0.58)$ & $31(15-51)$ \\
\hline 186 & $>50$ & Prostale & Bone Only & $8-10$ & $4-7$ & 1.3 & $0.69(0.57-0.83)$ & $0.48(0.34-0.68)$ & $0.24(0.12-0.48)$ & $24(13-36)$ \\
\hline 187 & $>50$ & Prostate & Bone Only & $8-10$ & 4.7 & 4.7 & $0.62(0.48-0.79)$ & $0.39(0.24-0.62)$ & $0.16(0.07-0.40)$ & $19(10-28)$ \\
\hline 188 & $>50$ & Prostate & Bone Only & $8-10$ & $4-7$ & $8-10$ & $0.68(0.54-0.86)$ & $0.47(0.30-0.74)$ & $0.24(0.10-0.56)$ & $23(10-38)$ \\
\hline 189 & $>50$ & Prostate & Bone Only & $8-10$ & $8-10$ & 0 & $0.72(0.61 .0 .86)$ & $0.53(0.39-0.73)$ & $0.30(0.16-0.55)$ & $28(14.44)$ \\
\hline 190 & $>50$ & Prostate & Bone Only & $8-10$ & $8-10$ & 1.3 & $066(0.53-0.81)$ & $0.44(0.29-0.66)$ & $0.21(0.10-0.45)$ & $20(11.33)$ \\
\hline 191 & $>50$ & Prostate & Bone Only & $8-10$ & $8 \cdot 10$ & 4.7 & $0.58(0.44-0.77)$ & $0.35(0.21 \cdot 0.59)$ & $0.13(0.05-0.36)$ & $16(9.26)$ \\
\hline 192 & $>50$ & Prostate & Bone Only & $8-10$ & $8-10$ & 8.10 & $0.65(0.51-0.83)$ & $0.43(0.27-0.69)$ & $0.20(0.08-0.50)$ & $20(10-34)$ \\
\hline
\end{tabular}


Appendix 4

Prognostic Index/ Nomogram: Predicted Survival Probability

\begin{tabular}{|c|c|c|c|c|c|c|c|c|c|c|}
\hline Scenario & $\begin{array}{l}\text { KPS } \\
\text { Score }\end{array}$ & $\begin{array}{l}\text { Primary Cancer } \\
\text { Site }\end{array}$ & $\begin{array}{c}\text { Site of } \\
\text { Metastases }\end{array}$ & $\begin{array}{l}\text { Appelite } \\
\text { Score }\end{array}$ & $\begin{array}{l}\text { Fatigue } \\
\text { Score }\end{array}$ & $\begin{array}{l}\text { Shortness of } \\
\text { Breath Score }\end{array}$ & $\begin{array}{c}\text { Predicted Survival } \\
\text { Probability at } 3 \text { months } \\
(95 \% \mathrm{Cl})\end{array}$ & $\begin{array}{c}\text { Predicted Survival } \\
\text { Probabitity at } 6 \text { months } \\
(95 \% \mathrm{Cl})\end{array}$ & $\begin{array}{c}\text { Predicted Survival } \\
\text { Probability at } 1 \text { year } \\
(95 \% \text { CI) }\end{array}$ & $\begin{array}{l}\text { Median } \\
\text { Survival in } \\
\text { weeks } \\
(95 \% \mathrm{Cl})\end{array}$ \\
\hline 193 & $>50$ & Prostate & Olhers & 0 & 0 & 0 & $0.81(0.72-0.93)$ & $0.67(0.52-0.86)$ & $0.46(0.29-0.74)$ & $47(17-80)$ \\
\hline 194 & $>50$ & Prostate & Others & 0 & 0 & 1.3 & $0.77(0.63-0.92)$ & $0.59(0.41-0.85)$ & $0.37(0.19-0.73)$ & $34(11-62)$ \\
\hline 195 & $>50$ & Prostate & Others & 0 & 0 & $4-7$ & $0.71(0.55-0.91)$ & $0.51(0.32-0.82)$ & $0.28(0.11-0.68)$ & $26(8-49)$ \\
\hline 196 & $>50$ & Prostate & Others & 0 & 0 & $8-10$ & $0.76(0.61-0.94)$ & $0.59(0.39-0.89)$ & $0.36(0.16-0.79)$ & $34(8-62)$ \\
\hline 197 & $>50$ & Prostate & Oiners & 0 & 1.3 & 0 & $0.77(0.68-0.87)$ & $0.60(0.48-0.76)$ & $0.38(0.25-0.58)$ & $35(19.55)$ \\
\hline 198 & $>50$ & Prostate & Others & 0 & $1-3$ & $1-3$ & $0.71(0.60-0.85)$ & $0.52(0.37-0.73)$ & $0.28(0.15-0.54)$ & $27(13-41)$ \\
\hline 199 & $>50$ & Prostate & Others & 0 & 1.3 & $4-7$ & $0.65(0.51-0.82)$ & $0.43(0.27-0.68)$ & $0.20(0.08-0.47)$ & $20(10-34)$ \\
\hline 200 & $>50$ & Prostate & Others & 0 & $1-3$ & $8-10$ & $0.71(0.57 \cdot 0.88)$ & $0.51(0.34-0.77)$ & $0.28(0.13-0.61)$ & $26(11-44)$ \\
\hline 201 & $>50$ & Prostate & Others & 0 & 4.7 & 0 & $0.71(0.61-0.83)$ & $0.51(0.38-0.69)$ & $0.28(0.16-0.49)$ & $26(14-38)$ \\
\hline 202 & $>50$ & Prostate & Others & 0 & $4-7$ & $1-3$ & $0.64(0.52-0.80)$ & $0.42(0.28-0.64)$ & $0.19(0.09-0.42)$ & $19(11-30)$ \\
\hline 203 & $>50$ & Prostate & Others & 0 & 4.7 & $4-7$ & $0.57(0.42-0.76)$ & $0.33(0.19-0.58)$ & $0.12(0.04-0.35)$ & $16(8.25)$ \\
\hline 204 & $>50$ & Prostate & Others & 0 & 4.7 & $8-10$ & $0.64(0.48-0.84)$ & $0.41(0.24-0.71)$ & $0.18(0.07-0.51)$ & $19(8-34)$ \\
\hline 205 & $>50$ & Prostate & Others & 0 & $8-10$ & 0 & $0.68(0.57-0.83)$ & $0.48(0.33-0.68)$ & $0.24(0.12-0.48)$ & $23(13-35)$ \\
\hline 206 & $>50$ & Prostate & Others & 0 & $8-10$ & $1-3$ & $0.61(0.47-0.79)$ & $0.38(0.23-0.63)$ & $0.16(0.06-0.41)$ & $19(9-29)$ \\
\hline 207 & $>50$ & Prostate & Others & 0 & $8-10$ & $4-7$ & $0.53(0.37-0.75)$ & $0.29(0.15-0.57)$ & $0.09(0.03-0.34)$ & $14(7.21)$ \\
\hline 208 & $>50$ & Prostate & Others & 0 & $8-10$ & $8-10$ & $0.60(0.44-0.82)$ & $0.37(0.21-0.67)$ & $0.15(0.05-0.46)$ & $18(8.29)$ \\
\hline 209 & $>50$ & Prostate & Others & $1 \cdot 3$ & 0 & 0 & $0.81(0.71-0.93)$ & $0.67(0.52-0.86)$ & $0.46(0.29-0.75)$ & $47(16-83)$ \\
\hline 210 & $>50$ & Prostate & Others & $1-3$ & 0 & $1-3$ & $0.77(0.64 \cdot 0.92)$ & $0.59(0.42-0.84)$ & $0.37(0.19-0.72)$ & $35(11-62)$ \\
\hline 211 & $>50$ & Prostate & Others & $1-3$ & 0 & 4.7 & $0.71(0.56-0.90)$ & $0.51(0.32-0.81)$ & $0.28(0.12-0.67)$ & $26(9-48)$ \\
\hline 212 & $>50$ & Prostate & Others & $1-3$ & 0 & $8-10$ & $076(0.62-0.94)$ & $0.59(0.39-0.88)$ & $0.36(0.17-0.78)$ & $34(8-62)$ \\
\hline 213 & $>50$ & Prostate & Others & $1-3$ & $1 \cdot 3$ & 0 & $0.77(0.68-0.88)$ & $0.60(0.47-0.77)$ & $0.38(0.24-0.60)$ & $35(19-59)$ \\
\hline 214 & $>50$ & Prostale & Others & $1-3$ & $1-3$ & 1.3 & $0.72(0.60-0.85)$ & $0.52(0.38-0.72)$ & $0.29(0.16-0.52)$ & $27(14-40)$ \\
\hline 215 & $>50$ & Prostate & Others & $1-3$ & $1-3$ & 4.7 & $0.65(0.52-0.82)$ & $0.43(0.28 .0 .66)$ & $0.20(0.09-0.45)$ & $20(11-33)$ \\
\hline 216 & $>50$ & Prostale & Others & $1-3$ & 1.3 & $8-10$ & $0.71(058 \cdot 0.88)$ & $0.51(0.34-0.76)$ & $0.28(0.13-0.59)$ & $26(11.44)$ \\
\hline 217 & $>50$ & Prostate & Others & $1-3$ & 4.7 & 0 & $0.71(061-0.84)$ & $0.51(0.38-0.70)$ & $0.28(0.16-0.49)$ & $27(14-39)$ \\
\hline 218 & $>50$ & Prostate & Others & 1.3 & 4.7 & 1.3 & $0.64(0.53-0.79)$ & $0.42(0.29-0.62)$ & $0.19(0.09-0.39)$ & $20(12.30)$ \\
\hline 219 & $>50$ & Prostate & Others & 1.3 & 4.7 & $4-7$ & $0.57(0.43-0.75)$ & $0.33(0.20-0.56)$ & $0.12(0.04-0.32)$ & $16(9.24)$ \\
\hline 220 & $>50$ & Prostate & Others & $1-3$ & 4.7 & 8.10 & $0.64(0.49-0.83)$ & $0.41(0.25-0.69)$ & $0.18(0.07-0.48)$ & $19(9-33)$ \\
\hline 221 & $>50$ & Prostate & Others & $1-3$ & $8-10$ & 0 & $0.69(0.56-0.84)$ & $0.48(0.32-0.70)$ & $0.24(0.12-0.50)$ & $24(12.36)$ \\
\hline 222 & $>50$ & Prostate & Others & 1.3 & $8-10$ & 1.3 & $061(0.47-079)$ & $0.38(0.23-0.63)$ & $0.16(0.06-0.40)$ & $19(9-28)$ \\
\hline 223 & $>50$ & Prostate & Oiners & 1.3 & $8-10$ & 4.7 & $0.53(0.38-0.75)$ & $0.29(0.15-0.56)$ & $0.09(0.03-0.33)$ & $14(7-21)$ \\
\hline 224 & $>50$ & Prostate & Others & 1.3 & $8-10$ & $8-10$ & $0.60(0.45-0.82)$ & $0.37(0.21-0.66)$ & $0.15(0.05-0.45)$ & $18(8-29)$ \\
\hline
\end{tabular}


Appendix 4

Prognostic Index/ Nomogram: Predicted Survival Probability

\begin{tabular}{|c|c|c|c|c|c|c|c|c|c|c|}
\hline Scenario & $\begin{array}{l}\text { KPS } \\
\text { Score }\end{array}$ & $\begin{array}{l}\text { Primary Cancer } \\
\text { Site }\end{array}$ & $\begin{array}{c}\text { Site of } \\
\text { Melastases }\end{array}$ & $\begin{array}{l}\text { Appetite } \\
\text { Score }\end{array}$ & $\begin{array}{l}\text { Fatigue } \\
\text { Score }\end{array}$ & $\begin{array}{l}\text { Shortness of } \\
\text { Breath Score }\end{array}$ & $\begin{array}{c}\text { Predicted Survival } \\
\text { Probability at } 3 \text { months } \\
\text { (95\% Cl) }\end{array}$ & $\begin{array}{l}\text { Predicted Survival } \\
\text { Probability at } 6 \text { months } \\
(95 \% \mathrm{Cl})\end{array}$ & $\begin{array}{c}\text { Predicted Survival } \\
\text { Probability at } 1 \text { year } \\
(95 \% \mathrm{Cl}) \\
0.46(0.28-0.76)\end{array}$ & $\begin{array}{l}\text { Median } \\
\text { Survival in } \\
\text { weeks } \\
(95 \% \mathrm{Cl}) \\
45(15-83)\end{array}$ \\
\hline 226 & $>50$ & Prostate & Others & 4.7 & 0 & $1-3$ & $0.76(0.63-0.92)$ & $0.59(0.41-0.85)$ & $0.37(0.18-0.73)$ & $34(11-62)$ \\
\hline 227 & $>50$ & Prostate & Others & 4.7 & 0 & 4.7 & $0.71(0.55-0.91)$ & $0.51(0.31-0.82)$ & $0.27(0.11-0.68)$ & $26(8-49)$ \\
\hline 228 & $>50$ & Prostate & Others & 4.7 & 0 & $8-10$ & $0.76(0.61-0.94)$ & $0.58(0.38-0.89)$ & $0.36(0.16-0.79)$ & $34(8-62)$ \\
\hline 229 & $>50$ & Prostate & Others & 4.7 & $1-3$ & 0 & $0.77(068-0.88)$ & $0.60(0.47 \cdot 0.77)$ & $0.38(0.24-0.59)$ & $35(19.58)$ \\
\hline 230 & $>50$ & Prostate & Others & $4-7$ & $1-3$ & $1-3$ & $0.71(0.60-0.85)$ & $0.52(0.37-0.72)$ & $0.28(0.15-0.52)$ & $27(14-40)$ \\
\hline 231 & $>50$ & Prostate & Others & $4-7$ & $1-3$ & 4.7 & $0.65(0.52-0.81)$ & $0.43(0.28-0.66)$ & $0.20(0.09-0.45)$ & $20(11-33)$ \\
\hline 232 & $>50$ & Prostale & Others & 4.7 & 1.3 & $8-10$ & $0.71(0.57-0.87)$ & $0.51(0.34-0.76)$ & $0.27(0.13-0.59)$ & $26(11-44)$ \\
\hline 233 & $>50$ & Prostate & Others & $4-7$ & 4.7 & 0 & $0.71(0.61-0.83)$ & $0.51(0.38-0.69)$ & $0.28(0.16-0.48)$ & $26(14-38)$ \\
\hline 234 & $>50$ & Prostate & Others & $4-7$ & $4-7$ & $1-3$ & $0.64(0.53-0.78)$ & $0.42(0.29 \cdot 0.61)$ & $0.19(0.09-0.38)$ & $19(12-29)$ \\
\hline 235 & $>50$ & Prostale & Others & 4.7 & $4-7$ & 4.7 & $0.56(0.43-0.74)$ & $0.33(0.19-0.55)$ & $0.12(0.04-0.31)$ & $16(9-24)$ \\
\hline 236 & $>50$ & Prostate & Others & $4-7$ & 4.7 & $8-10$ & $0.63(0.49-0.83)$ & $0.41(0.25-0.68)$ & $0.18(0.07-0.47)$ & $19(9-33)$ \\
\hline 237 & $>50$ & Prostale & Others & $4-7$ & $8-10$ & 0 & $0.68(0.56-0.83)$ & $0.47(0.33-0.68)$ & $0.24(0.12-0.48)$ & $23(12-35)$ \\
\hline 238 & $>50$ & Prostate & Others & $4-7$ & $8-10$ & 1.3 & $0.61(0.48-0.78)$ & $0.38(024-0.61)$ & $0.16(0.07-0.38)$ & $18(10-27)$ \\
\hline 239 & $>50$ & Prostate & Others & $4-7$ & $8-10$ & $4-7$ & $0.53(0.38-0.73)$ & $0.29(0.15-0.54)$ & $0.09(0.03-0.30)$ & $14(7-20)$ \\
\hline 240 & $>50$ & Prostate & Others & 4.7 & $8-10$ & $8-10$ & $0.60(0.45-0.80)$ & $0.37(0.21-0.64)$ & $0.15(0.05-0.43)$ & $18(8.28)$ \\
\hline 241 & $>50$ & Prostate & Others & 8.10 & 0 & 0 & $0.70(0.54-0.90)$ & $0.49(0.30-0.81)$ & $0.26(0.10-0.6 \epsilon)$ & $25(8-44)$ \\
\hline 242 & $>50$ & Proslate & Others & $8-10$ & 0 & 1.3 & $0.62(0.44 \cdot 0.89)$ & $0.40(0.20-0.79)$ & $0.17(0.05-0.63)$ & $19(6-35)$ \\
\hline 243 & $>50$ & Prostate & Others & $8-10$ & 0 & $4-7$ & $0.55(0.35-0.86)$ & $0.31(0.13-0.74)$ & $0.10(0.02-0.56)$ & $15(5-26)$ \\
\hline 244 & $>50$ & Prostate & Others & 8.10 & 0 & $8 \cdot 10$ & $0.62(0.42 .0 .91)$ & $0.39(0.18-0.84)$ & $0.17(0.04-0.71)$ & $19(4-35)$ \\
\hline 245 & $>50$ & Prostate & Others & $8-10$ & $1-3$ & 0 & $0.63(0.49-0.82)$ & $0.41(0.25-0.67)$ & $0.18(0.07-0.47)$ & $19(9-32)$ \\
\hline 246 & $>50$ & Prostate & Others & $8-10$ & $1-3$ & 1.3 & $0.55(0.39-0.78)$ & $032(0.16-061)$ & $0.11(0.03-0.39)$ & $15(7-24)$ \\
\hline 247 & $>50$ & Prostate & Others & 8.10 & 1.3 & 4.7 & $0.47(0.30-0.73)$ & $0.23(0.10-0.53)$ & $0.06(0.01-0.30)$ & $12(6-19)$ \\
\hline 248 & $>50$ & Prostate & Others & $8-10$ & $1-3$ & 8.10 & $0.55(0.37-0.81)$ & $0.31(0.14-0.66)$ & $0.10(0.02-0.45)$ & $15(6-26)$ \\
\hline 249 & $>50$ & Prostate & Others & $8-10$ & 4.7 & 0 & $0.55(0.40-0.75)$ & $0.31(0.17-0.57)$ & $0.11(0.03-0.34)$ & $15(8-23)$ \\
\hline 250 & $>50$ & Prostate & Others & $8 \cdot 10$ & $4-7$ & $1-3$ & $0.46(0.31-0.69)$ & $0.22(0.10-0.48)$ & $0.05(0.01 \cdot 0.25)$ & $12(6-18)$ \\
\hline 251 & $>50$ & Prostate & Olners & $8-10$ & $4-7$ & 4.7 & $0.37(0.22-0.62)$ & $0.14(0.05-0.39)$ & $0.02(0.00-0.17)$ & $9(5-14)$ \\
\hline 252 & $>50$ & Prostate & Others & 8.10 & 4.7 & $8-10$ & $0.45(0.27-0.74)$ & $0.21(0.08-0.55)$ & $0.05(0.01-0.33)$ & $12(5-19)$ \\
\hline 253 & $>50$ & Prostate & Olhers & $8-10$ & 8.10 & 0 & $0.51(0.36-0.73)$ & $0.27(0.14-0.53)$ & $0.08(0.02-0.30)$ & $14(7-20)$ \\
\hline 254 & $>50$ & Prostate & Others & $8-10$ & 8.10 & 1.3 & $042(0.27-0.66)$ & $0.18(0.08-0.44)$ & $0.04(0.01-0.21)$ & $11(6-16)$ \\
\hline 255 & $>50$ & Prostate & Others & $8-10$ & $8-10$ & $4-7$ & $0.33(0.18-0.58)$ & $0.11(0.04-0.35)$ & $0.02(0.00-0.13)$ & $8(4-13)$ \\
\hline 256 & $>50$ & Prostate & Olhers & $8-10$ & $8 \cdot 10$ & $8-10$ & $0.41(0.25-0.69)$ & $0.18(0.07-0.48)$ & $0.04(0.01-0.24)$ & $11(5-16)$ \\
\hline
\end{tabular}


Appendix 4

Prognostic Index/ Nomogram: Predicted Survival Probability

\begin{tabular}{|c|c|c|c|c|c|c|c|c|c|c|}
\hline Scenario & $\begin{array}{l}\text { KPS } \\
\text { Score }\end{array}$ & $\begin{array}{c}\text { Primary Cancer } \\
\text { Site }\end{array}$ & $\begin{array}{c}\text { Site of } \\
\text { Metastases }\end{array}$ & $\begin{array}{l}\text { Appelite } \\
\text { Score }\end{array}$ & $\begin{array}{l}\text { Fatigue } \\
\text { Score }\end{array}$ & $\begin{array}{l}\text { Shortness of } \\
\text { Breath Score }\end{array}$ & $\begin{array}{c}\text { Predicled Survival } \\
\text { Probability al } 3 \text { months } \\
\text { (95\% Cl) }\end{array}$ & $\begin{array}{c}\text { Predicted Survival } \\
\text { Probability at } 6 \text { months } \\
\text { (95\% Cl) }\end{array}$ & $\begin{array}{c}\text { Predicted Survival } \\
\text { Probability at } 1 \text { year } \\
\text { (95\% Cl) }\end{array}$ & $\begin{array}{l}\text { Median } \\
\text { Survival in } \\
\text { weeks } \\
(95 \% \mathrm{Cl})\end{array}$ \\
\hline 257 & $>50$ & Lung & Bone Only & 0 & 0 & 0 & $0.90(0.84-0.96)$ & $0.81(0.71-0.93)$ & $0.67(0.52-0.86)$ & \\
\hline 258 & $>50$ & Lung & Bone Only & 0 & 0 & $1-3$ & $0.87(0.79-0.96)$ & $0.76(0.63-0.92)$ & $0.59(0.42-0.84)$ & $70(20)$. \\
\hline 259 & $>50$ & Lung & Bone Only & 0 & 0 & $4-7$ & $0.84(0.74-0.95)$ & $0.70(0.55-0.90)$ & $0.51(0.32-0.81)$ & $53(15-)$ \\
\hline 260 & $>50$ & Lung & Bone Only & 0 & 0 & $8-10$ & $0.87(0.78 \cdot 0.97)$ & $0.76(0.61-0.94)$ & $0.59(0.39-0.88)$ & $70(15-)$ \\
\hline 261 & $>50$ & Lung & Bone Only & 0 & $1-3$ & 0 & $0.87(0.82-0.93)$ & $0.77(0.68-0.87)$ & $0.60(0.47-0.77)$ & 75 (35-) \\
\hline 262 & $>50$ & Lung & Bone Only & 0 & $1-3$ & 1.3 & $0.84(0.77-0.92)$ & $0.71(0.60-0.84)$ & $0.52(0.38 \cdot 0.72)$ & $55(26-88)$ \\
\hline 263 & $>50$ & Lung & Bone Only & 0 & $1-3$ & 4.7 & $0.80(0.71-0.90)$ & $0.64(0.51 .081)$ & $0.43(0.28-0.66)$ & $40(19-66)$ \\
\hline 264 & $>50$ & Lung & Bone Only & 0 & $1-3$ & $8-10$ & $0.84(0.75-0.93)$ & $0.70(0.57 \cdot 0.87)$ & $0.51(0.34-0.76)$ & $53(20-93)$ \\
\hline 265 & $>50$ & Lung & Bone Only & 0 & $4-7$ & 0 & $0.84(0.77-0.91)$ & $0.71(0.60-0.83)$ & $0.51(0.38-0.70)$ & $54(27-84)$ \\
\hline 266 & $>50$ & Lung & Bone Only & 0 & 4.7 & $1-3$ & $0.79(0.71-0.88)$ & $0.64(0.52 \cdot 0.78)$ & $0.42(0.28-0.62)$ & $39(20-62)$ \\
\hline 267 & $>50$ & Lung & Bone Only & 0 & 4.7 & $4-7$ & $0.74(0.64-0.86)$ & $0.56(0.42-0.74)$ & $0.33(0.19-0.56)$ & $30(15-49)$ \\
\hline 268 & $>50$ & Lung & Bone Only & 0 & $4-7$ & $8-10$ & $0.79(0.69-0.91)$ & $0.63(0.48-0.82)$ & $0.41(0.25-0.69)$ & $38(16-63)$ \\
\hline 269 & $>50$ & Lung & Bone Only & 0 & $8-10$ & 0 & $0.82(0.74-0.91)$ & $0.68(0.55 \cdot 0.83)$ & $0.48(0.32-0.71)$ & $49(20-80)$ \\
\hline 270 & $>50$ & Lung & Bone Only & 0 & $8 \cdot 10$ & $1-3$ & $0.77(0.67-0.89)$ & $0.60(0.46-0.79)$ & $0.38(0.23-0.63)$ & $35(16-60)$ \\
\hline 271 & $>50$ & Lung & Bone Only & 0 & $8-10$ & $4-7$ & $0.72(0.60-0.86)$ & $0.52(0.37 \cdot 0.74)$ & $0.29(0.15-0.57)$ & $27(13-41)$ \\
\hline 272 & $>50$ & Lung & Bone Only & 0 & $8-10$ & $8-10$ & $0.77(0.66-0.90)$ & $0.60(0.44-0.81)$ & $0.37(0.21-0.66)$ & $35(14-60)$ \\
\hline 273 & $>50$ & Lung & Bone Only & 1.3 & 0 & 0 & $0.90(0.84 .097)$ & $0.81(0.71-0.93)$ & $0.67(0.52-0.87)$ & \\
\hline 274 & $>50$ & Lung & Bone Only & 1.3 & 0 & $1-3$ & $0.87(0.79-0.96)$ & $0.76(0.64-0.91)$ & $0.59(0.42-0.84)$ & $71(21 \cdot)$ \\
\hline 275 & $>50$ & Lung & Bone Only & 1.3 & 0 & $4-7$ & $0.84(0.74-0.95)$ & $0.71(0.56-0.89)$ & $0.51(0.33-0.80)$ & $54(16-)$ \\
\hline 276 & $>50$ & Lung & Bone Only & 1.3 & 0 & $8-10$ & $0.87(0.78 .0 .97)$ & $0.76(0.62-0.93)$ & $0.59(0.40-0.87)$ & $70(16-)$ \\
\hline 277 & $>50$ & Lung & Bone Only & $1-3$ & 1.3 & 0 & $0.87(0.82 .0 .94)$ & $0.77(0.67-0.88)$ & $0.60(0.47 \cdot 0.78)$ & $75(35-)$ \\
\hline 278 & $>50$ & Lung & Bone Only & 1.3 & $1-3$ & 1.3 & $0.84(0.77 .091)$ & $0.71(0.60-0.84)$ & $0.52(0.38-0.70)$ & $58(28-88)$ \\
\hline 279 & $>50$ & Lung & Bone Only & 1.3 & $1-3$ & $4-7$ & $0.80(0.71-0.89)$ & $0.64(0.52-0.80)$ & $0.43(0.29-0.65)$ & $40(20-63)$ \\
\hline 280 & $>50$ & Lung & Bone Only & 1.3 & $1-3$ & $8-10$ & $0.84(0.75-0.93)$ & $0.71(0.58-0.86)$ & $0.51(0.35-0.75)$ & $54(21.93)$ \\
\hline 281 & $>50$ & Lung & Bone Only & $1 \cdot 3$ & $4-7$ & 0 & $084(0.77-0.91)$ & $0.71(0.60-0.83)$ & $0.52(0.38-0.70)$ & $55(27-84)$ \\
\hline 282 & $>50$ & Lung & Bone Only & 1.3 & $4-7$ & $1-3$ & $0.79(0.72-0.88)$ & $0.64(0.53-0.77)$ & $0.42(0.30-0.60)$ & $39(23-61)$ \\
\hline 283 & $>50$ & Lung & Bone Only & 1.3 & 4.7 & $4-7$ & $0.74(0.65 \cdot 0.85)$ & $0.56(0.44-0.72)$ & $0.33(0.20-0.54)$ & $30(17-47)$ \\
\hline 284 & $>50$ & Lung & Bone Only & 1.3 & 4.7 & $8-10$ & $0.79(0.69-0.90)$ & $0.63(0.49-0.81)$ & $0.41(0.26-0.66)$ & $38(18-62)$ \\
\hline 285 & $>50$ & Lung & Bone Only & 1.3 & $8-10$ & 0 & $0.82(0.73-0.92)$ & $0.68(0.55-0.84)$ & $0.48(0.32-0.72)$ & $49(19.83)$ \\
\hline 286 & $>50$ & Lung & Bone Only & $1 \cdot 3$ & $8 \cdot 10$ & $1-3$ & $0.77(0.68 .0 .88)$ & $0.61(0.47 \cdot 0.78)$ & $0.38(0.24-0.62)$ & $35(17-59)$ \\
\hline 287 & $>50$ & Lung & Bone Only & 1.3 & 8.10 & 4.7 & $0.72(0.60 .0 .86)$ & $0.53(0.37-0.74)$ & $0.29(0.15-0.55)$ & $27(13-41)$ \\
\hline 288 & $>50$ & Lung & Bone Only & $1 \cdot 3$ & $8-10$ & $8-10$ & $0.77(0.66-0.90)$ & $0.60(0.45 \cdot 0.80)$ & $0.37(0.22-0.65)$ & $35(15.61)$ \\
\hline
\end{tabular}


Appendix 4

Prognostic Index/ Nomogram: Predicted Survival Probability

\begin{tabular}{|c|c|c|c|c|c|c|c|c|c|c|}
\hline Scenario & $\begin{array}{l}\text { KPS } \\
\text { Score }\end{array}$ & $\begin{array}{l}\text { Primary Cancer } \\
\text { Site }\end{array}$ & $\begin{array}{c}\text { Site of } \\
\text { Metastases }\end{array}$ & $\begin{array}{l}\text { Appetite } \\
\text { Score }\end{array}$ & $\begin{array}{c}\text { Fatigue } \\
\text { Score }\end{array}$ & $\begin{array}{l}\text { Shornness of } \\
\text { Breath Score }\end{array}$ & $\begin{array}{c}\text { Predicted Survival } \\
\text { Probability at } 3 \text { months } \\
\text { (95\% Cl) }\end{array}$ & $\begin{array}{c}\text { Predicted Survival } \\
\text { Probability at } 6 \text { months } \\
\text { (95\% CI) }\end{array}$ & $\begin{array}{l}\text { Predicted Survival } \\
\text { Probability at } 1 \text { year } \\
(95 \% \mathrm{CI})\end{array}$ & $\begin{array}{l}\text { Median } \\
\text { Survival in } \\
\text { weeks } \\
(95 \% \mathrm{Cl})\end{array}$ \\
\hline 289 & $>50$ & Lung & Bone Only & $4 \cdot 7$ & 0 & 0 & $0.90(0.83-0.97)$ & $0.81(0.70-0.94)$ & $0.67(0.51-0.88)$ & \\
\hline 290 & $>50$ & Lung & Bone Only & 4.7 & 0 & 1.3 & $0.87(0.79-0.96)$ & $0.76(0.63-0.92)$ & $0.59(0.41-0.85)$ & $70(20-)$ \\
\hline 291 & $>50$ & Lung & Bone Only & $4-7$ & 0 & 4.7 & $0.84(0.73-0.95)$ & $0.70(0.55-0.90)$ & $0.51(0.32-0.82)$ & $53(15-)$ \\
\hline 292 & $>50$ & Lung & Bone Only & $4-7$ & 0 & $8-10$ & $0.87(0.77-0.97)$ & $0.76(0.61-0.94)$ & $0.58(0.39-0.88)$ & $70(15-)$ \\
\hline 293 & $>50$ & Lung & Bone Only & $4-7$ & $1-3$ & 0 & $0.87(0.81-0.94)$ & $0.77(0.67-0.88)$ & $0.60(0.47-0.77)$ & $72(35-)$ \\
\hline 294 & $>50$ & Lung & Bone Only & 4.7 & $1-3$ & $1-3$ & $0.84(0.77-0.91)$ & $0.71(0.60-0.84)$ & $0.52(0.38-0.70)$ & $55(27-84)$ \\
\hline 295 & $>50$ & Lung & Bone Only & $4-7$ & 1.3 & $4-7$ & $0.80(0.71-0.89)$ & $0.64(0.52-0.80)$ & $0.43(0.28-0.65)$ & $40(20-63)$ \\
\hline 296 & $>50$ & Lung & Bone Only & $4-7$ & $1-3$ & $8-10$ & $0.84(0.75 .0 .93)$ & $0.70(0.57-0.86)$ & $0.51(0.35-0.75)$ & $53(20.93)$ \\
\hline 297 & $>50$ & Lung & Bone Only & $4-7$ & $4-7$ & 0 & $0.84(0.77-0.91)$ & $0.71(0.60-0.83)$ & $0.51(0.38-0.70)$ & $54(27-84)$ \\
\hline 298 & $>50$ & Lung & Bone Only & $4-7$ & $4-7$ & 1.3 & $0.79(0.72-0.87)$ & $0.64(0.53-0.76)$ & $0.42(0.30-0.59)$ & $39(23-60)$ \\
\hline 299 & $>50$ & Lung & Bone Only & $4-7$ & $4-7$ & $4-7$ & $0.74(0.65-0.85)$ & $0.56(0.43-0.72)$ & $0.33(0.20-0.53)$ & $30(16-45)$ \\
\hline 300 & $>50$ & Lung & Bone Only & $4-7$ & $4-7$ & $8 \cdot 10$ & $0.79(0.69 \cdot 0.90)$ & $0.63(0.49-0.81)$ & $0.41(0.26-0.66)$ & $38(18-62)$ \\
\hline 301 & $>50$ & Lung & Bone Only & $4-7$ & $8 \cdot 10$ & 0 & $0.82(0.73-0.91)$ & $0.68(0.55-0.84)$ & $0.48(0.32-0.71)$ & $49(20-80)$ \\
\hline 302 & $>50$ & Lung & Bone Only & 4.7 & $8-10$ & $1-3$ & $0.77(0.68-0.88)$ & $0.60(0.47-0.77)$ & $0.38(0.24-0.60)$ & $35(18-59)$ \\
\hline 303 & $>50$ & Lung & Bone Only & $4-7$ & $8-10$ & $4-7$ & $0.72(0.60-0.85)$ & $0.52(0.38-0.72)$ & $0.29(0.15-0.54)$ & $27(14-41)$ \\
\hline 304 & $>50$ & Lung & Bone Only & 4.7 & $8-10$ & B-10 & $0.77(0.66-0.89)$ & $0.60(0.45 \cdot 0.79)$ & $0.37(0.22-0.64)$ & $35(15-59)$ \\
\hline 305 & $>50$ & Lung & Bone Only & $8 \cdot 10$ & 0 & 0 & $083(0.73-0.94)$ & $0.69(0.54-0.89)$ & $0.49(0.30-0.80)$ & $52(14-93)$ \\
\hline 306 & $>50$ & Lung & Bone Only & $8-10$ & 0 & $1-3$ & $0.78(0.66-0.93)$ & $0.62(0.44-0.87)$ & $0.40(0.21-0.76)$ & $36(11-70)$ \\
\hline 307 & $>50$ & Lung & Bone Only & $8-10$ & 0 & 4.7 & $073(0$ 58-0.91) & $0.54(0.35-0.83)$ & $0.31(0.13-0.70)$ & $29(9-52)$ \\
\hline 308 & $>50$ & Lung & Bone Only & $8-10$ & 0 & $8-10$ & $0.78(0.64-0.94)$ & $0.61(0.42-0.89)$ & $0.39(0.19-0.80)$ & $36(9-70)$ \\
\hline 309 & $>50$ & Lung & Bone Only & $8-10$ & 1.3 & 0 & $0.79(0.69-0.90)$ & $0.63(0.49-0.81)$ & $0.41(0.26-0.66)$ & $38(17-63)$ \\
\hline 310 & $>50$ & Lung & Bone Only & $8-10$ & 1.3 & $1-3$ & $0.73(0.62 .0 .87)$ & $0.55(0.40 \cdot 0.75)$ & $0.32(0.17-0.58)$ & $29(14-48)$ \\
\hline 311 & $>50$ & Lung & Bone Only & $8-10$ & $1-3$ & $4-7$ & $0.67(0.55-0.83)$ & $0.46(0.31-0.69)$ & $0.23(0.11-0.49)$ & $22(11-35)$ \\
\hline 312 & $>50$ & Lung & Bone Only & $8-10$ & $1-3$ & 8.10 & $0.73(0.60-0.88)$ & $0.54(0.38-0.78)$ & $0.31(0.15 \cdot 0.62)$ & $29(12-49)$ \\
\hline 313 & $>50$ & Lung & Bone Only & $8-10$ & $4 \cdot 7$ & 0 & $0.73(0.62-0.86)$ & $0.54(0.40-0.74)$ & $0.31(0.17-0.56)$ & $29(14-45)$ \\
\hline 314 & $>50$ & Lung & Bone Only & $8-10$ & $4-7$ & $1-3$ & $0.67(0.55-0.80)$ & $0.45(0.32-0.65)$ & $0.22(0.11-0.44)$ & $21(13-33)$ \\
\hline 315 & $>50$ & Lung & Bone Only & $8-10$ & $4-7$ & $4 \cdot 7$ & $0.59(0.47-0.76)$ & $0.36(0.23-0.57)$ & $0.14(0.06-0.35)$ & $17(10-26)$ \\
\hline 316 & $>50$ & Lung & Bone Only & $8 \cdot 10$ & $4-7$ & $8-10$ & $0.66(0.52-0.83)$ & $0.44(0.28-0.69)$ & $0.21(0.09-0.50)$ & $20(10-35)$ \\
\hline 317 & $>50$ & Lung & Bone Only & $8-10$ & $8-10$ & 0 & $0.71(0.59-0.85)$ & $0.51(0.36-0.72)$ & $0.27(0.14-0.54)$ & $26(13-39)$ \\
\hline 318 & $>50$ & Lung & Bone Only & $8-10$ & $8 \cdot 10$ & 1.3 & $0.64(0.51-0.79)$ & $0.41(0.27-0.63)$ & $0.18(0.08-0.41)$ & $19(11-30)$ \\
\hline 319 & $>50$ & Lung & Bone Only & $8-10$ & $8 \cdot 10$ & $4-7$ & $0.56(0.42-0.74)$ & $0.32(0.19 \cdot 0.55)$ & $0.11(0.04-0.32)$ & $15(9-22)$ \\
\hline 320 & $>50$ & Lung & Bone Only & $8-10$ & $8-10$ & $8-10$ & $0.63(0.49-0.80)$ & $0.40(0.25-0.65)$ & $0.18(0.07-0.44)$ & $19(10-30)$ \\
\hline
\end{tabular}


Appendix 4

Prognostic Index/ Nomogram: Predicted Survival Probability

\begin{tabular}{|c|c|c|c|c|c|c|c|c|c|c|}
\hline Scenario & $\begin{array}{l}\text { KPS } \\
\text { Score }\end{array}$ & $\begin{array}{c}\text { Primary Cancer } \\
\text { Site }\end{array}$ & $\begin{array}{c}\text { Site of } \\
\text { Metastases }\end{array}$ & $\begin{array}{l}\text { Appelite } \\
\text { Score }\end{array}$ & $\begin{array}{c}\text { Fatigue } \\
\text { Score }\end{array}$ & $\begin{array}{l}\text { Shortness of } \\
\text { Breath Score }\end{array}$ & $\begin{array}{l}\text { Predicted Survival } \\
\text { Probability at } 3 \text { months } \\
(95 \% \mathrm{CI})\end{array}$ & $\begin{array}{l}\text { Predicled Survival } \\
\text { Probability at } 6 \text { months } \\
(95 \% \mathrm{CI})\end{array}$ & $\begin{array}{c}\text { Predicled Survival } \\
\text { Probability at } 1 \text { year } \\
\text { (95\% Cl) }\end{array}$ & $\begin{array}{l}\text { Median } \\
\text { Survival in } \\
\text { weeks } \\
(95 \% \mathrm{Cl})\end{array}$ \\
\hline 321 & $>50$ & Lung & Others & 0 & 0 & 0 & $080(0.70 .091)$ & $0.65(0.51-0.83)$ & $0.43(0.27-0.69)$ & $40(18-70)$ \\
\hline 322 & $>50$ & Lung & Others & 0 & 0 & $1-3$ & $0.75(0.63-0.90)$ & $0.57(0.40-0.81)$ & $0.34(0.17-0.66)$ & $31(12-54)$ \\
\hline 323 & $>50$ & Lung & Others & 0 & 0 & 4.7 & $0.69(0.54-0.87)$ & $0.48(0.31-0.76)$ & $0.25(0.10-0.60)$ & $24(9-39)$ \\
\hline 324 & $>50$ & Lung & Others & 0 & 0 & $8-10$ & $0.74(0.60 .0 .92)$ & $0.56(0.38-0.84)$ & $0.33(0.15-0.71)$ & $30(10.58)$ \\
\hline 325 & $>50$ & Lung & Others & 0 & $1-3$ & 0 & $0.76(0.67-0.85)$ & $0.58(0.47-0.72)$ & $0.35(0.23-0.53)$ & $33(19-49)$ \\
\hline 326 & $>50$ & Lung & Others & 0 & 1.3 & $1-3$ & $0.70(0.59-0.82)$ & $0.49(0.36-0.67)$ & $0.26(0.14-0.46)$ & $25(14-35)$ \\
\hline 327 & $>50$ & Lung & Others & 0 & $1-3$ & $4-7$ & $0.63(0.51-0.77)$ & $0.40(0.27-0.60)$ & $0.17(0.08-0.38)$ & $19(11-28)$ \\
\hline 328 & $>50$ & Lung & Others & 0 & $1-3$ & $8-10$ & $0.69(0.57 \cdot 0.84)$ & $0.48(0.33-0.70)$ & $0.25(0.12-0.51)$ & $24(12-37)$ \\
\hline 329 & $>50$ & Lung & Others & 0 & $4-7$ & 0 & $0.69(0.60-0.80)$ & $0.49(0.37-0.64)$ & $0.25(0.15-0.42)$ & $25(15-35)$ \\
\hline 330 & $>50$ & Lung & Olners & 0 & $4-7$ & $1-3$ & $0.62(0.51-0.75)$ & $0.39(0.28-0.56)$ & $0.17(0.08-0.33)$ & $19(12-27)$ \\
\hline 331 & $>50$ & Lung & Others & 0 & $4-7$ & $4-7$ & $0.54(0.42-0.70)$ & $0.30(0.18-0.49)$ & $0.10(0.04-0.26)$ & $14(9-20)$ \\
\hline 332 & $>50$ & Lung & Others & 0 & $4-7$ & 8.10 & $061(0.48-0.79)$ & $0.38(0.24-0.62)$ & $0.16(0.06-0.40)$ & $19(10-28)$ \\
\hline 333 & $>50$ & Lung & Others & 0 & $8-10$ & 0 & $0.66(0.55-0.80)$ & $0.45(0.32-0.64)$ & $0.22(0.11-0.42)$ & $21(13-32)$ \\
\hline 334 & $>50$ & Lung & Others & 0 & $8-10$ & $1-3$ & $0.59(0.46-0.75)$ & $0.35(0.22-0.56)$ & $0.14(0.06-0.33)$ & $16(10-25)$ \\
\hline 335 & $>50$ & Lung & Others & 0 & $8-10$ & $4-7$ & $0.50(0.37-0.69)$ & $0.26(0.14-0.48)$ & $0.08(0.02-0.25)$ & $13(8-19)$ \\
\hline 336 & $>50$ & Lung & Others & 0 & $8-10$ & $8-10$ & $0.58(0.44-0.76)$ & $0.34(0.20-0.59)$ & $0.13(0.05-0.36)$ & $16(9-26)$ \\
\hline 337 & $>50$ & Lung & Others & $1-3$ & 0 & 0 & $0.80(0.70-0.91)$ & $0.65(0.51-0.83)$ & $0.44(0.27-0.70)$ & $41(17-70)$ \\
\hline 338 & $>50$ & Lung & Olners & $1 \cdot 3$ & 0 & $1-3$ & $0.75(0.63-0.89)$ & $0.57(0.41-0.80)$ & $0.34(0.18-0.64)$ & $31(13.53)$ \\
\hline 339 & $>50$ & Lung & Others & $1-3$ & 0 & 4.7 & $0.69(0.55-0.87)$ & $0.49(0.31-0.75)$ & $0.25(0.11-0.58)$ & $25(10-39)$ \\
\hline 340 & $>50$ & Lung & Others & $1-3$ & 0 & $8-10$ & $075(0.61 .091)$ & $0.56(0.38-0.83)$ & $0.33(0.16-0.69)$ & $31(11.58)$ \\
\hline 341 & $>50$ & Lung & Others & $1-3$ & 1.3 & 0 & $0.76(0.67-085)$ & $0.58(0.46-0.73)$ & $0.35(0.23-0.54)$ & $33(19-49)$ \\
\hline 342 & $>50$ & Lung & Others & 1.3 & $1-3$ & 1.3 & $0.70(0.60-0.81)$ & $0.49(0.38-0.65)$ & $0.26(0.15-0.43)$ & $25(15-35)$ \\
\hline 343 & $>50$ & Lung & Others & $1-3$ & 1.3 & $4-7$ & $0.63(0.52-0.76)$ & $0.40(028-0.58)$ & $0.18(0.09-0.35)$ & $19(12-27)$ \\
\hline 344 & $>50$ & Lung & Others & $1-3$ & $1-3$ & $8-10$ & $0.69(0.57-0.83)$ & $0.49(0.34-0.69)$ & $0.25(0.13-0.49)$ & $25(13-36)$ \\
\hline 345 & $>50$ & Lung & Others & 1.3 & 4.7 & 0 & $0.69(0.60-0.80)$ & $0.49(0.37-0.64)$ & $0.25(0.15-0.42)$ & $25(15-35)$ \\
\hline 346 & $>50$ & Lung & Others & 1.3 & $4-7$ & $1-3$ & $062(0.53-0.72)$ & $0.39(0.30-0.53)$ & $0.17(0.10-0.29)$ & $19(13-26)$ \\
\hline 347 & $>50$ & Lung & Others & 1.3 & $4-7$ & $4-7$ & $0.54(0.44-0.67)$ & $0.30(0.20 .0 .45)$ & $0.10(0.05-0.22)$ & $14(10-19)$ \\
\hline 348 & $>50$ & Lung & Others & $1-3$ & $4-7$ & 8.10 & $061(0.49-0.77)$ & $039(0.25-0.59)$ & $0.16(0.07-0.37)$ & $19(11-27)$ \\
\hline 349 & $>50$ & Lung & Others & $1-3$ & $8-10$ & 0 & $0.67(0.55-0.81)$ & $0.45(0.31-0.65)$ & $0.22(0.11 .0 .44)$ & $21(12-33)$ \\
\hline 350 & $>50$ & Lung & Others & $1-3$ & $8 \cdot 10$ & $1-3$ & $0.59(0.47-0.74)$ & $035(0.23-0.55)$ & $0.14(0.06-0.31)$ & $17(10-24)$ \\
\hline 351 & $>50$ & Lung & Others & $1-3$ & $8-10$ & $4-7$ & $0.51(0.38 .0 .68)$ & $0.26(0.15-0.47)$ & $0.08(0.03-0.23)$ & $13(8.19)$ \\
\hline 352 & $>50$ & Lung & Others & $1-3$ & $8-10$ & $8-10$ & $0.58(045-0.76)$ & $0.35(0.21-0.57)$ & $0.13(0.05-0.34)$ & $16(9-25)$ \\
\hline
\end{tabular}


Appendix 4

Prognostic Index/ Nomogram: Predicted Survival Probability

\begin{tabular}{|c|c|c|c|c|c|c|c|c|c|c|}
\hline Scenario & $\begin{array}{l}\text { KPS } \\
\text { Score }\end{array}$ & $\begin{array}{l}\text { Primary Cancer } \\
\text { Site }\end{array}$ & $\begin{array}{c}\text { Site of } \\
\text { Metaslases }\end{array}$ & $\begin{array}{l}\text { Appetite } \\
\text { Score }\end{array}$ & $\begin{array}{l}\text { Fatigue } \\
\text { Score }\end{array}$ & $\begin{array}{l}\text { Shortness of } \\
\text { Breath Score }\end{array}$ & $\begin{array}{c}\text { Predicted Survival } \\
\text { Probability at } 3 \text { months } \\
\text { (95\% Cl) } \\
0.80(0.70 .092)\end{array}$ & $\begin{array}{c}\text { Predicted Survival } \\
\text { Probability at } 6 \text { months } \\
(95 \% \mathrm{Cl}) \\
0.65(0.50-0.84)\end{array}$ & $\begin{array}{c}\text { Predicted Survival } \\
\text { Probability at } 1 \text { year } \\
(95 \% \mathrm{Cl}) \\
0.43(0.26 \cdot 0.71)\end{array}$ & $\begin{array}{l}\text { Median } \\
\text { Survival in } \\
\text { weeks } \\
(95 \% \text { Cl) } \\
40(16-71)\end{array}$ \\
\hline 354 & $>50$ & Lung & Others & $4-7$ & 0 & $1-3$ & $075(0.62-090)$ & $0.57(0.40-0.80)$ & $0.34(0.17-0.66)$ & $31(12-54)$ \\
\hline 355 & $>50$ & Lung & Others & $4-7$ & 0 & $4-7$ & $0.69(0.54-0.87)$ & $0.48(0.31-0.76)$ & $0.25(0.10-0.59)$ & $24(9-39)$ \\
\hline 356 & $>50$ & Lung & Others & $4-7$ & 0 & $8 \cdot 10$ & $0.74(0.60-0.92)$ & $0.56(0.37-0.84)$ & $0.33(0.15-0.71)$ & $30(10-58)$ \\
\hline 357 & $>50$ & Lung & Others & $4-7$ & $1-3$ & 0 & $0.76(067.0 .85)$ & $0.58(0.46-0.72)$ & $0.35(0.23-0.53)$ & $33(19-49)$ \\
\hline 358 & $>50$ & Lung & Olhers & $4-7$ & 1.3 & 1.3 & $0.69(0.60-0.80)$ & $0.49(0.37-0.65)$ & $0.26(0.15 \cdot 0.43)$ & $25(15-35)$ \\
\hline 359 & $>50$ & Lung & Others & 4.7 & 1.3 & 4.7 & $0.63(0.52-0.76)$ & $0.40(0.28-0.58)$ & $0.17(0.09-0.35)$ & $19(12-27)$ \\
\hline 360 & $>50$ & Lung & Others & $4-7$ & 1.3 & $8-10$ & $0.69(0.57-0.83)$ & $0.48(0.34-0.69)$ & $0.25(0.13-0.49)$ & $24(13-36)$ \\
\hline 361 & $>50$ & Lung & Others & $4-7$ & 4.7 & 0 & $0.69(0.60-0.79)$ & $0.49(0.37-0.63)$ & $0.25(0.15-0.41)$ & $25(15-34)$ \\
\hline 362 & $>50$ & Lung & Others & $4-7$ & 4.7 & $1-3$ & $0.62(0.53-0.72)$ & $0.39(0.30-0.52)$ & $0.17(0.10-0.28)$ & $19(13-26)$ \\
\hline 363 & $>50$ & Lung & Others & $4-7$ & 4.7 & $4-7$ & $0.54(0.44-0.67)$ & $0.30(0.20-0.45)$ & $0.10(0.05-0.22)$ & $14(10-19)$ \\
\hline 364 & $>50$ & Lung & Others & $4-7$ & 4.7 & $8-10$ & $0.61(0.49-0.77)$ & $0.38(0.25-0.59)$ & $0.16(0.07-0.36)$ & $19(11-27)$ \\
\hline 365 & $>50$ & Lung & Others & $4-7$ & $8 \cdot 10$ & 0 & $0.66(0.55-0.79)$ & $0.45(0.32-0.63)$ & $0.21(0.11-0.41)$ & $20(13.31)$ \\
\hline 366 & $>50$ & Lung & Others & $4-7$ & 8-10 & 1.3 & $0.59(0.48 \cdot 0.72)$ & $0.35(0.24-0.52)$ & $0.14(0.06-0.29)$ & $16(11-23)$ \\
\hline 367 & $>50$ & Lung & Others & $4-7$ & $8-10$ & $4-7$ & $0.50(0.38-0.66)$ & $0.26(0.15-0.44)$ & $0.08(0.03-0.21)$ & $13(8.19)$ \\
\hline 368 & $>50$ & Lung & Others & $4-7$ & $8 \cdot 10$ & $8 \cdot 10$ & $0.58(0.45-0.74)$ & $0.34(0.21-0.55)$ & $0.13(0.05-0.32)$ & $16(9-24)$ \\
\hline 369 & $>50$ & Lung & Others & $8-10$ & 0 & 0 & $0.68(0.53-0.87)$ & $0.47(0.29-0.75)$ & $0.23(0.09-0.58)$ & $22(9-38)$ \\
\hline 370 & $>50$ & Lung & Others & $8-10$ & 0 & $1-3$ & $0.60(0.43-0.84)$ & $0.37(0.19-0.71)$ & $0.15(0.04-0.52)$ & $18(6-30)$ \\
\hline 371 & $>50$ & Lung & Others & $8-10$ & 0 & 4.7 & $0.52(0.34-0.80)$ & $0.28(0.12-0.64)$ & $0.09(0.02-0.43)$ & $14(6-23)$ \\
\hline 372 & $>50$ & Lung & Olhers & $8-10$ & 0 & $8-10$ & $0.59(0.41 .0 .86)$ & $0.36(0.18-0.75)$ & $0.14(0.04-0.58)$ & $17(6-30)$ \\
\hline 373 & $>50$ & Lung & Others & $8 \cdot 10$ & $1-3$ & 0 & $0.61(0.48-0.78)$ & $0.38(0.24-0.61)$ & $0.16(0.07-0.39)$ & $19(10-28)$ \\
\hline 374 & $>50$ & Lung & Others & $8-10$ & 1.3 & $1-3$ & $0.53(0.39-0.72)$ & $0.29(0.16 \cdot 0.52)$ & $0.09(0.03-0.29)$ & $14(8-20)$ \\
\hline 375 & $>50$ & Lung & Others & $8-10$ & $1-3$ & $4-7$ & $0.44(0.30-0.65)$ & $0.20(0.10-0.42)$ & $0.05(0.01-0.20)$ & $11(6-16)$ \\
\hline 376 & $>50$ & Lung & Others & $8-10$ & $1-3$ & $8 \cdot 10$ & $0.52(0.37 \cdot 0.74)$ & $0.28(0.14 .055)$ & $0.09(0.02-0.33)$ & $14(7-20)$ \\
\hline 377 & $>50$ & Lung & Others & $8-10$ & $4-7$ & 0 & $0.52(0.39-0.70)$ & $0.28(0.16-0.49)$ & $0.09(0.03-0.26)$ & $14(8-19)$ \\
\hline 378 & $>50$ & Lung & Others & $8-10$ & $4-7$ & $1-3$ & $0.43(0.31-0.60)$ & $0.19(0.10-0.37)$ & $0.04(0.01-0.15)$ & $11(7.15)$ \\
\hline 379 & $>50$ & Lung & Others & 8.10 & 4.7 & $4-7$ & $034(0.22-0.52)$ & $0.12(0.05 \cdot 0.28)$ & $0.02(0.00-0.09)$ & $9(6-12)$ \\
\hline 380 & $>50$ & Lung & Others & $8 \cdot 10$ & $4-7$ & $8 \cdot 10$ & $0.42(0.28-0.65)$ & $0.19(0.08-0.43)$ & $0.04(0.01-0.20)$ & $11(6-16)$ \\
\hline 381 & $>50$ & Lung & Others & $8 \cdot 10$ & $8-10$ & 0 & $049(0.35-0.67)$ & $0.24(0.13-0.46)$ & $0.07(0.02-0.23)$ & $13(7-19)$ \\
\hline 382 & $>50$ & Lung & Others & $8-10$ & $8-10$ & $1-3$ & $0.39(0.27-0.58)$ & $0.16(0.08-0.34)$ & $0.03(0.01-0.13)$ & $10(6-14)$ \\
\hline 383 & $>50$ & Lung & Others & $8-10$ & $8-10$ & 4.7 & $0.30(0.19-0.48)$ & $0.10(0.04-0.24)$ & $0.01(0.00-0.07)$ & $8(5-11)$ \\
\hline 384 & $>50$ & Lung & Others & $8-10$ & 8.10 & $8-10$ & $038(025.059)$ & $0.15(0.07-0.35)$ & $0.03(0.01-0.14)$ & $10(6-14)$ \\
\hline
\end{tabular}




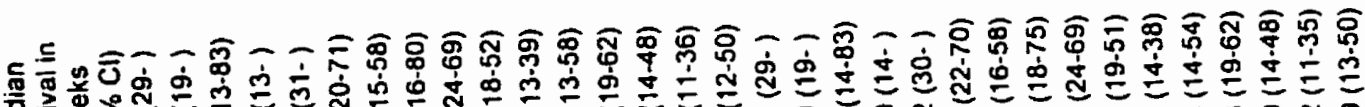

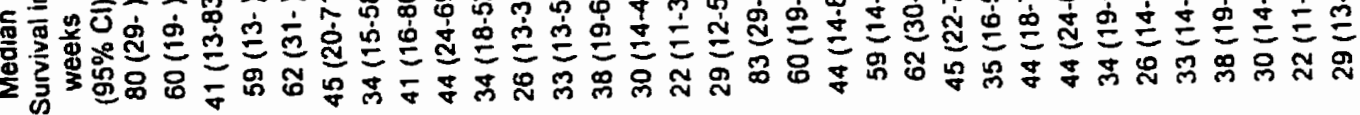

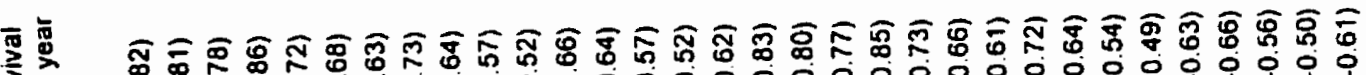

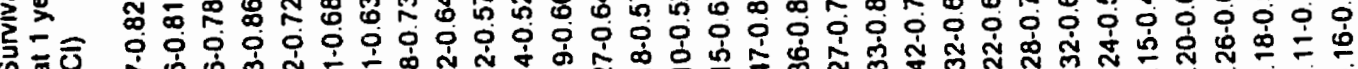

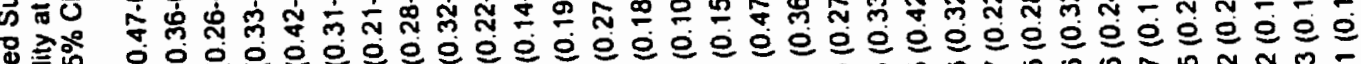

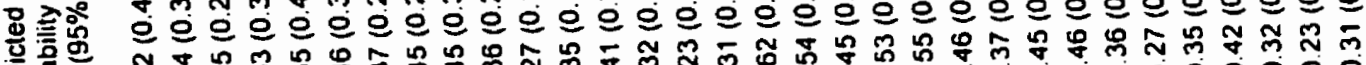
渮 웅

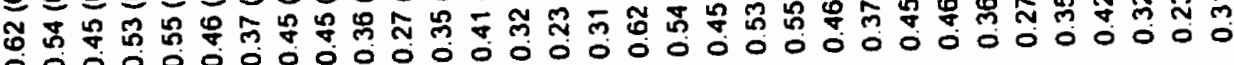

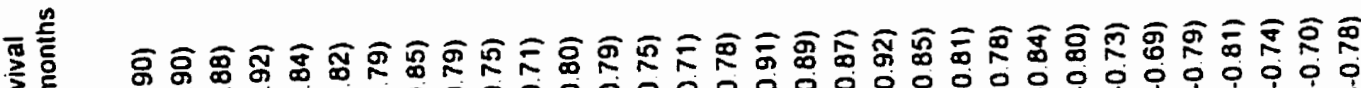

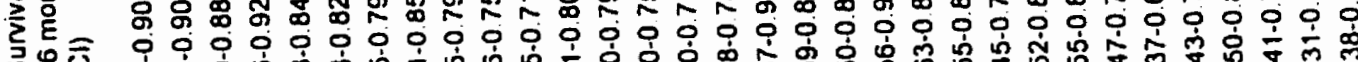

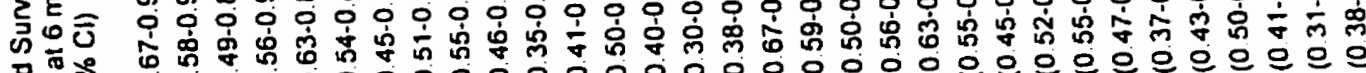

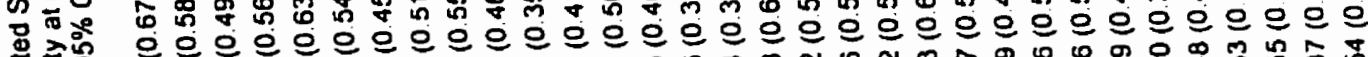
源

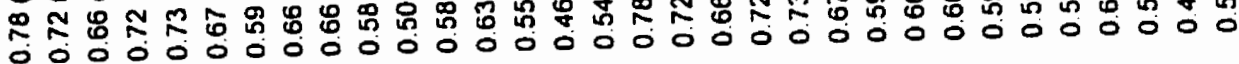

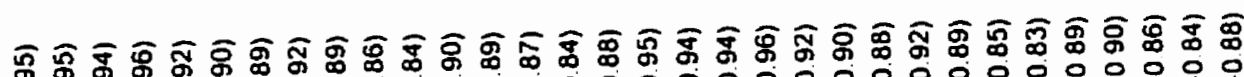

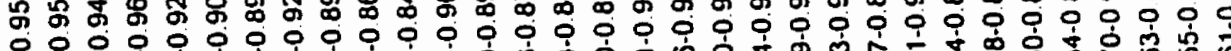

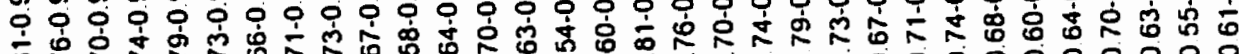

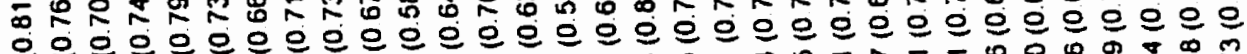

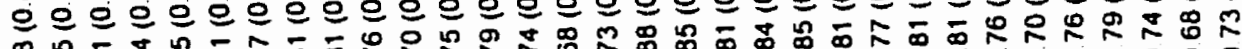

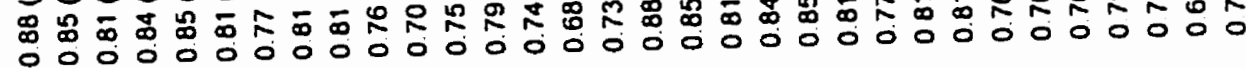

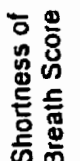

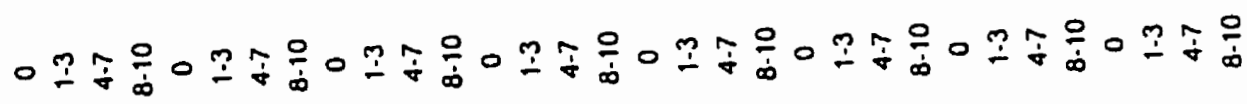

兽产总

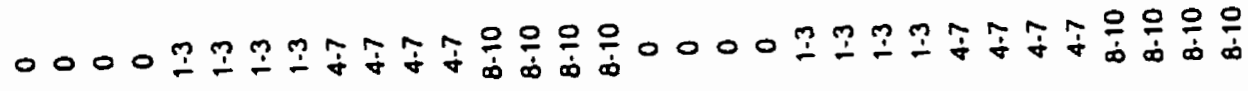

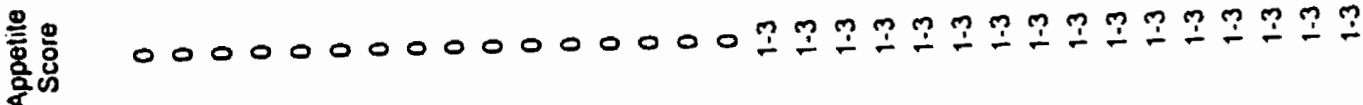

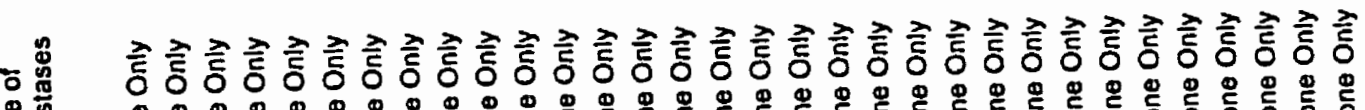

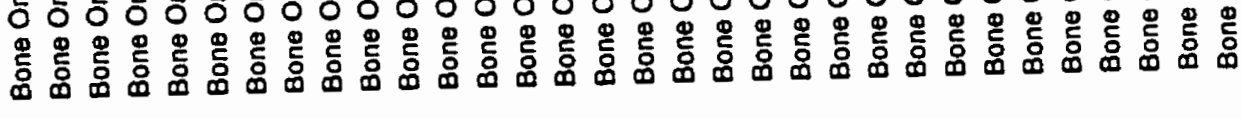

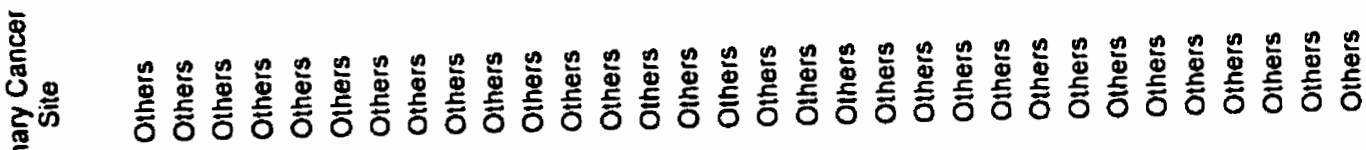
हैं

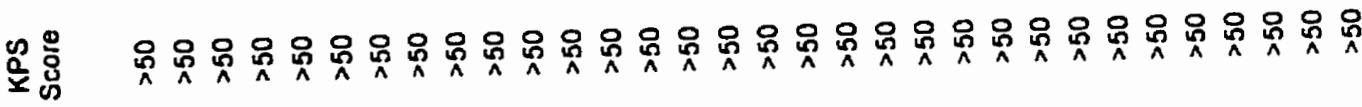

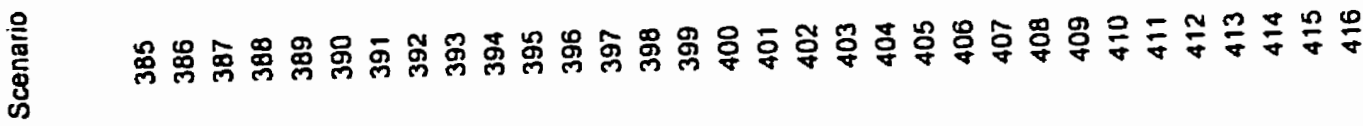


Appendix 4

Prognostic Index/ Nomogram: Predicted Survival Probability

\begin{tabular}{|c|c|c|c|c|c|c|c|c|c|c|}
\hline Scenario & $\begin{array}{l}\text { KPS } \\
\text { Score }\end{array}$ & $\begin{array}{c}\text { Primary Cancer } \\
\text { Site }\end{array}$ & $\begin{array}{c}\text { Site of } \\
\text { Metastases }\end{array}$ & $\begin{array}{l}\text { Appelite } \\
\text { Score }\end{array}$ & $\begin{array}{c}\text { Fatigue } \\
\text { Score }\end{array}$ & $\begin{array}{l}\text { Shortness of } \\
\text { Breath Score }\end{array}$ & $\begin{array}{l}\text { Predicted Survival } \\
\text { Probability at } 3 \text { months } \\
(95 \% \mathrm{Cl})\end{array}$ & $\begin{array}{c}\text { Predicted Survival } \\
\text { Probability at } 6 \text { months } \\
\text { (95\% Cl) }\end{array}$ & $\begin{array}{c}\text { Predicted Survival } \\
\text { Probability at } 1 \text { year } \\
(95 \% \mathrm{Cl})\end{array}$ & $\begin{array}{l}\text { Median } \\
\text { Survival in } \\
\text { weeks } \\
(95 \% \text { Cl) }\end{array}$ \\
\hline 417 & $>50$ & Others & Bone Only & 4.7 & 0 & 0 & $0.88(0.81-0.95)$ & $0.78(0.67-0.91)$ & $0.62(0.46-0.83)$ & $80(28-)$ \\
\hline 418 & $>50$ & Others & Bone Only & $4-7$ & 0 & $1-3$ & $0.85(0.76 .0 .95)$ & $0.72(0.58-0.89)$ & $0.54(0.36-0.80)$ & $60(19-)$ \\
\hline 419 & $>50$ & Others & Bone Only & $4-7$ & 0 & $4-7$ & $0.81(0.70-0.94)$ & $0.66(0.49-0.88)$ & $0.45(0.26-0.77)$ & $41(14-83)$ \\
\hline 420 & $>50$ & Others & Bone Only & $4-7$ & 0 & $8-10$ & $0.84(0.74-0.96)$ & $0.72(0.56-0.92)$ & $0.53(0.33-0.85)$ & $59(14 \cdot)$ \\
\hline 421 & $>50$ & Others & Bone Only & $4-7$ & $1-3$ & 0 & $0.85(0.79-0.92)$ & $0.73(0.63-0.84)$ & $0.55(0.42-0.72)$ & $62(31-93)$ \\
\hline 422 & $>50$ & Others & Bone Only & $4-7$ & 1.3 & 1.3 & $0.81(0.74-0.89)$ & $0.66(0.55-0.80)$ & $0.46(0.32-0.65)$ & $44(23-70)$ \\
\hline 423 & $>50$ & Others & Bone Only & $4-7$ & $1-3$ & 4.7 & $0.76(0.67-0.88)$ & $0.59(0.46-0.77)$ & $0.37(0.22 \cdot 0.60)$ & $34(17-54)$ \\
\hline 424 & $>50$ & Others & Bone Only & 4.7 & $1-3$ & 8.10 & $0.81(0.71-0.92)$ & $0.66(0.52-0.84)$ & $0.45(0.29-0.71)$ & $41(18-72)$ \\
\hline 425 & $>50$ & Others & Bone Only & 4.7 & $4-7$ & 0 & $0.81(0.74-0.89)$ & $0.66(0.56-0.78)$ & $0.45(0.33-0.62)$ & $44(26-63)$ \\
\hline 426 & $>50$ & Others & Bone Only & 4.7 & 4.7 & $1-3$ & $0.76(0.68-0.85)$ & $0.58(0.48-0.72)$ & $0.36(0.24-0.52)$ & $34(19-49)$ \\
\hline 427 & $>50$ & Others & Bone Only & $4-7$ & 4.7 & 4.7 & $0.70(0.60-0.82)$ & $0.50(0.37-0.68)$ & $0.27(0.15-0.47)$ & $26(14-38)$ \\
\hline 428 & $>50$ & Others & Bone Only & $4-7$ & $4-7$ & $8 \cdot 10$ & $0.75(0.65 \cdot 0.88)$ & $0.58(0.43-0.78)$ & $0.35(0.20-0.61)$ & $33(14-53)$ \\
\hline 429 & $>50$ & Others & Bone Only & $4-7$ & $8-10$ & 0 & $079(0.70-0.89)$ & $0.63(0.51-0.79)$ & $0.41(0.27-0.63)$ & $38(19-62)$ \\
\hline 430 & $>50$ & Others & Bone Only & $4-7$ & $8-10$ & $1-3$ & $0.74(0.64-0.85)$ & $0.55(0.42-0.72)$ & $0.32(0.19-0.53)$ & $29(16-44)$ \\
\hline 431 & $>50$ & Others & Bone Only & 4.7 & $8-10$ & 4.7 & $0.67(0.55-0.82)$ & $0.46(0.32-0.68)$ & $0.23(0.11-0.47)$ & $22(12-35)$ \\
\hline 432 & $>50$ & Others & Bone Only & 4.7 & $8-10$ & $8 \cdot 10$ & $0.73(0.61-0.87)$ & $0.54(0.39-0.75)$ & $0.31(0.16-0.58)$ & $29(13-48)$ \\
\hline 433 & $>50$ & Others & Bone Only & $8 \cdot 10$ & 0 & 0 & $0.80(0.69-0.93)$ & $0.65(0.49 \cdot 0.86)$ & $0.43(0.25-0.74)$ & $40(14-75)$ \\
\hline 434 & $>50$ & Others & Bone Only & $8 \cdot 10$ & 0 & 1.3 & $0.75(0.61-0.91)$ & $0.57(0.38-0.83)$ & $0.34(0.16-0.71)$ & $31(10-59)$ \\
\hline 435 & $>50$ & Others & Bone Only & $8-10$ & 0 & $4-7$ & $0.69(0.53-0.89)$ & $0.48(0.29-0.80)$ & $0.25(0.09-0.65)$ & $24(8-41)$ \\
\hline 436 & $>50$ & Others & Bone Only & $8-10$ & 0 & 8.10 & $0.74(0.59-0.93)$ & $0.56(0.36-0.87)$ & $0.33(0.14-0.76)$ & $30(8-60)$ \\
\hline 437 & $>50$ & Olhers & Bone Only & $8-10$ & $1-3$ & 0 & $075(0.65-0.87)$ & $0.58(0.44-0.76)$ & $0.35(0.20-0.60)$ & $33(15-52)$ \\
\hline 438 & $>50$ & Others & Bone Only & $8-10$ & $1-3$ & $1-3$ & $0.69(0.57-0.84)$ & $0.49(0.34-0.71)$ & $0.25(0.13-0.52)$ & $25(12.38)$ \\
\hline 439 & $>50$ & Oiners & Bone Only & $8-10$ & $1-3$ & 4.7 & $0.62(0.48-0.81)$ & $0.40(0.24-0.65)$ & $0.17(0.07-0.44)$ & $19(9-30)$ \\
\hline 440 & $>50$ & Oihers & Bone Only & $8-10$ & 1.3 & $8-10$ & $0.69(055.087)$ & $0.48(0.31-0.75)$ & $0.25(0.10-0.58)$ & $24(10-39)$ \\
\hline 441 & $>50$ & Olhers & Bone Only & $8-10$ & $4-7$ & 0 & $069(0.58-082)$ & $0.48(0.34-0.68)$ & $0.25(0.13-0.48)$ & $24(13-36)$ \\
\hline 442 & $>50$ & Others & Bone Only & $8-10$ & $4-7$ & $1-3$ & $0.62(0.50-0.77)$ & $0.39(0.26-0.59)$ & $0.16(0.07-0.37)$ & $19(11-27)$ \\
\hline 443 & $>50$ & Olhers & Bone Only & $8-10$ & $4-7$ & $4-7$ & $0.54(0.40-0.72)$ & $0.30(0.17-0.53)$ & $0.10(0.03-0.30)$ & $14(8-20)$ \\
\hline 444 & $>50$ & Others & Bone Only & 8.10 & $4-7$ & 8.10 & $061(046-081)$ & $0.38(022.0 .66)$ & $0.16(0.05-0.46)$ & $19(8-29)$ \\
\hline 445 & $>50$ & Others & Bone Only & $8-10$ & $8 \cdot 10$ & 0 & $066(0.54-0.81)$ & $0.45(0.30-0.66)$ & $0.21(0.10-0.45)$ & $20(12-33)$ \\
\hline 446 & $>50$ & Others & Bone Only & $8-10$ & $8-10$ & $1-3$ & $0.58(0.46-0.75)$ & $035(0.22-0.57)$ & $0.13(0.05 \cdot 0.34)$ & $16(9-25)$ \\
\hline 447 & $>50$ & Others & Bone Only & $8-10$ & $8-10$ & 4.7 & $0.50(0.36-0.70)$ & $0.26(0.14-0.49)$ & $0.08(0.02-0.26)$ & $13(7-19)$ \\
\hline 448 & $>50$ & Others & Bone Only & $8-10$ & $8-10$ & $8-10$ & $0.58(0.43-0.77)$ & $0.34(0.19 \cdot 0.60)$ & $0.13(0.04-0.38)$ & $16(8-26)$ \\
\hline
\end{tabular}




\section{Appendix 4}

Prognostic Index/ Nomogram: Predicted Survival Probability

\begin{tabular}{|c|c|c|c|c|c|c|c|c|c|c|}
\hline Scenario & $\begin{array}{l}\text { KPS } \\
\text { Score }\end{array}$ & $\begin{array}{c}\text { Primary Cancer } \\
\text { Site }\end{array}$ & $\begin{array}{l}\text { Site of } \\
\text { Metastases }\end{array}$ & $\begin{array}{l}\text { Appetite } \\
\text { Score }\end{array}$ & $\begin{array}{l}\text { Fatigue } \\
\text { Score }\end{array}$ & $\begin{array}{l}\text { Shortness of } \\
\text { Breath Score }\end{array}$ & $\begin{array}{c}\text { Predicted Survival } \\
\text { Probability at } 3 \text { months } \\
(95 \% \mathrm{Cl})\end{array}$ & $\begin{array}{c}\text { Predicled Survival } \\
\text { Probability at } 6 \text { months } \\
(95 \% \mathrm{Cl})\end{array}$ & $\begin{array}{c}\text { Predicted Survival } \\
\text { Probability at } 1 \text { year } \\
(95 \% \mathrm{Cl})\end{array}$ & $\begin{array}{l}\text { Median } \\
\text { Survival in } \\
\text { weeks } \\
(95 \% \mathrm{Cl})\end{array}$ \\
\hline 449 & $>50$ & Others & Others & 0 & 0 & 0 & $0.77(0.66-0.89)$ & $0.60(0.45-0.79)$ & $0.37(0.22-0.63)$ & $35(15-59)$ \\
\hline 450 & $>50$ & Others & Others & 0 & 0 & $1-3$ & $0.71(057-088)$ & $0.51(0.34-0.78)$ & $0.28(0.12-0.61)$ & $26(10-44)$ \\
\hline 451 & $>50$ & Others & Others & 0 & 0 & 4.7 & $0.64(0.48-0.86)$ & $0.42(0.24-0.74)$ & $0.19(0.07-0.56)$ & $20(8-35)$ \\
\hline 452 & $>50$ & Others & Others & 0 & 0 & $8 \cdot 10$ & $0.70(0.55-0.91)$ & $0.50(0.31-0.82)$ & $0.27(0.11-0.69)$ & $26(8-48)$ \\
\hline 453 & $>50$ & Others & Others & 0 & 1.3 & 0 & $0.72(0.62-0.83)$ & $0.52(0.40-0.68)$ & $0.29(0.18-0.48)$ & $27(16-38)$ \\
\hline 454 & $>50$ & Others & Others & 0 & $1-3$ & $1-3$ & $0.65(0.53-0.80)$ & $0.43(0.29-0.64)$ & $0.20(0.09-0.42)$ & $20(11-31)$ \\
\hline 455 & $>50$ & Others & Others & 0 & 1.3 & 4.7 & $0.57(0.43-0.76)$ & $0.34(0.20-0.59)$ & $0.13(0.04-0.36)$ & $16(8-26)$ \\
\hline 456 & $>50$ & Others & Others & 0 & $1-3$ & $8 \cdot 10$ & $0.64(0.50-0.83)$ & $0.42(0.26-0.69)$ & $0.19(0.07-0.50)$ & $20(9-34)$ \\
\hline 457 & $>50$ & Others & Others & 0 & $4-7$ & 0 & $0.65(0.54-0.77)$ & $0.43(0.30-0.59)$ & $0.19(0.10 \cdot 0.37)$ & $20(13-29)$ \\
\hline 458 & $>50$ & Others & Others & 0 & $4 \cdot 7$ & $1-3$ & $0.57(0.44-0.73)$ & $0.33(0.20-0.53)$ & $0.12(0.05-0.30)$ & $16(10.23)$ \\
\hline 459 & $>50$ & Others & Others & 0 & $4-7$ & $4-7$ & $0.48(0.34-0.69)$ & $0.24(0.12-0.47)$ & $0.07(0.02-0.24)$ & $13(7-19)$ \\
\hline 460 & $>50$ & Others & Others & 0 & $4-7$ & $8-10$ & $0.56(0.40-0.78)$ & $0.32(0.17 \cdot 0.61)$ & $0.11(0.03-0.39)$ & $15(7-25)$ \\
\hline 461 & $>50$ & Others & Others & 0 & $8 \cdot 10$ & 0 & $0.61(0.49-0.76)$ & $0.39(0.25-0.59)$ & $0.16(0.07-0.36)$ & $19(11-27)$ \\
\hline 462 & $>50$ & Others & Others & 0 & 8.10 & $1-3$ & $0.53(039-0.72)$ & $0.29(0.16-0.52)$ & $0.09(0.03-0.29)$ & $14(8-20)$ \\
\hline 463 & $>50$ & Others & Others & 0 & $8-10$ & $4-7$ & $0.44(0.29-0.67)$ & $0.20(0.09-0.46)$ & $0.05(0.01-0.22)$ & $11(6-16)$ \\
\hline 464 & $>50$ & Others & Others & 0 & $8 \cdot 10$ & $8-10$ & $052(0.37-0.75)$ & $0.28(0.14-0.56)$ & $0.09(0.02-0.33)$ & $14(7-20)$ \\
\hline 465 & $>50$ & Others & Others & $1-3$ & 0 & 0 & $0.77(0.66 \cdot 0.89)$ & $0.60(0.45 \cdot 0.80)$ & $0.37(0.22-0.64)$ & $35(15-59)$ \\
\hline 466 & $>50$ & Others & Others & $1-3$ & 0 & 1.3 & $0.71(0.58-0.87)$ & $0.51(034-0.76)$ & $0.28(0.13-0.59)$ & $26(11-44)$ \\
\hline 467 & $>50$ & Others & Others & 1.3 & 0 & $4-7$ & $064(049.085)$ & $0.42(0.25-0.73)$ & $0.19(0.07-0.54)$ & $20(8-34)$ \\
\hline 468 & $>50$ & Olners & Others & 1.3 & 0 & $8-10$ & $0.71(0.55-0.90)$ & $0.51(0.31-0.81)$ & $0.27(0.11-0.66)$ & $26(8-48)$ \\
\hline 469 & $>50$ & Others & Others & $1-3$ & $1-3$ & 0 & $072(0.62-0.83)$ & $0.52(0.40-0.69)$ & $0.29(0.17-0.49)$ & $27(15.39)$ \\
\hline 470 & $>50$ & Others & Others & 1.3 & $1-3$ & 1.3 & $0.65(054.0 .79)$ & $0.43(0.30-0.62)$ & $0.20(0.10-0.40)$ & $20(12-30)$ \\
\hline 471 & $>50$ & Olhers & Others & $1-3$ & $1-3$ & $4-7$ & $0.58(0.44-0.75)$ & $0.34(0.21-0.56)$ & $0.13(0.05-0.33)$ & $16(9-25)$ \\
\hline 472 & $>50$ & Others & Others & $1-3$ & $1-3$ & 8.10 & $064(0.51-0.82)$ & $0.42(0.27-0.68)$ & $0.19(0.08-0.47)$ & $20(10-33)$ \\
\hline 473 & $>50$ & Others & Others & $1-3$ & 4.7 & 0 & $0.65(0.54-0.77)$ & $0.43(0.31 .0 .59)$ & $0.20(0.11-0.36)$ & $20(13-29)$ \\
\hline 474 & $>50$ & Others & Others & $1-3$ & 4.7 & 1.3 & $057(0.46-0.70)$ & $0.33(0.22-0.49)$ & $0.12(0.06-0.26)$ & $16(11-21)$ \\
\hline 475 & $>50$ & Others & Olhers & 1.3 & 4.7 & 4.7 & $0.48(0.35 \cdot 0.66)$ & $0.24(0.13-0.44)$ & $0.07(0.02-0.20)$ & $13(8-18)$ \\
\hline 476 & $>50$ & Others & Olners & $1-3$ & 4.7 & $8-10$ & $0.56(0.41-0.76)$ & $0.32(0.18-0.58)$ & $0.11(0.04-0.35)$ & $15(8-23)$ \\
\hline 477 & $>50$ & Others & Olhers & $1-3$ & $8 \cdot 10$ & 0 & $062(0.49-0.77)$ & $0.39(0.25-0.60)$ & $0.16(0.07-0.37)$ & $19(10-27)$ \\
\hline 478 & $>50$ & Others & Others & $1-3$ & 8.10 & $1-3$ & $0.53(0.40 \cdot 0.71)$ & $0.29(0.17-0.51)$ & $0.10(0.03-0.27)$ & $14(8-20)$ \\
\hline 479 & $>50$ & Others & Others & $1-3$ & $8-10$ & 4.7 & $0.45(0.30-0.66)$ & $0.21(0.10-0.44)$ & $0.05(0.01-0.21)$ & $11(6-16)$ \\
\hline 480 & $>50$ & Others & Others & $1-3$ & $8-10$ & $8-10$ & $0.53(0.37-0.74)$ & $0.28(0.15-0.55)$ & $0.09(0.03-0.31)$ & $14(7-20)$ \\
\hline
\end{tabular}


Appendix 4

Prognostic Index/ Nomogram: Predicted Survival Probability

\begin{tabular}{|c|c|c|c|c|c|c|c|c|c|c|}
\hline Scenario & $\begin{array}{l}\text { KPS } \\
\text { Score }\end{array}$ & $\begin{array}{c}\text { Primary Cancer } \\
\text { Site }\end{array}$ & $\begin{array}{c}\text { Site of } \\
\text { Metastases }\end{array}$ & $\begin{array}{l}\text { Appetite } \\
\text { Score }\end{array}$ & $\begin{array}{l}\text { Fatıgue } \\
\text { Score }\end{array}$ & $\begin{array}{l}\text { Shortness of } \\
\text { Breath Score }\end{array}$ & $\begin{array}{c}\text { Predicted Survival } \\
\text { Probability at } 3 \text { months } \\
(95 \% \mathrm{C}) \\
0.77(0.66-0.89)\end{array}$ & $\begin{array}{c}\text { Predicted Survival } \\
\text { Probability al } 6 \text { months } \\
(95 \% \mathrm{Cl}) \\
0.60(0.45-0.80)\end{array}$ & $\begin{array}{c}\text { Predicled Survival } \\
\text { Probability at } 1 \text { year } \\
(95 \% \mathrm{Cl}) \\
0.37(0.21-0.64)\end{array}$ & $\begin{array}{c}\text { Median } \\
\text { Survival in } \\
\text { weeks } \\
(95 \% \text { Cl) } \\
35(15-59)\end{array}$ \\
\hline 482 & $>50$ & Others & Others & 4.7 & 0 & $1-3$ & $0.71(057-087)$ & $0.51(0.34-0.77)$ & $0.28(0.13-0.60)$ & $26(11-44)$ \\
\hline 483 & $>50$ & Others & Others & 4.7 & 0 & 4.7 & $0.64(0.48 \cdot 0.85)$ & $0.42(0.24-0.73)$ & $0.19(0.07-0.54)$ & $19(8-34)$ \\
\hline 484 & $>50$ & Others & Others & $4-7$ & 0 & $8-10$ & $0.70(0.55-0.90)$ & $0.50(0.31-0.81)$ & $0.27(0.11-0.67)$ & $26(8-48)$ \\
\hline 485 & $>50$ & Olners & Others & 4.7 & $1-3$ & 0 & $0.72(0.63-0.82)$ & $0.52(0.40-0.67)$ & $0.29(0.18-0.46)$ & $27(16-38)$ \\
\hline 486 & $>50$ & Others & Others & $4-7$ & 1.3 & 1.3 & $0.65(0.54-0.78)$ & $0.43(0.30-0.60)$ & $0.20(0.10-0.38)$ & $20(13-30)$ \\
\hline 487 & $>50$ & Olhers & Others & $4-7$ & 1.3 & 4.7 & $0.57(0.45-0.74)$ & $0.34(0.21-0.55)$ & $0.13(0.05-0.31)$ & $16(9-24)$ \\
\hline 488 & $>50$ & Olners & Others & 4.7 & 1.3 & 8.10 & $0.64(0.51-0.81)$ & $0.42(0.27-0.66)$ & $0.19(0.08-0.45)$ & $19(10-31)$ \\
\hline 489 & $>50$ & Olhers & Others & 4.7 & 4.7 & 0 & $0.64(0.55-0.75)$ & $0.42(0.32-0.57)$ & $0.19(0.11-0.34)$ & $20(14-27)$ \\
\hline 490 & $>50$ & Oiners & Others & $4-7$ & $4-7$ & 1.3 & $0.57(0.47-0.68)$ & $0.33(0.23-0.47)$ & $0.12(0.06-0.23)$ & $16(11-20)$ \\
\hline 491 & $>50$ & Others & Others & $4-7$ & 4.7 & $4-7$ & $0.48(0.36-0.64)$ & $0.24(0.14-0.41)$ & $0.06(0.02 \cdot 0.18)$ & $13(8-17)$ \\
\hline 492 & $>50$ & Others & Others & $4-7$ & $4-7$ & $8-10$ & $0.56(0.42-0.74)$ & $0.32(0.18-0.55)$ & $0.11(0.04-0.32)$ & $15(8-23)$ \\
\hline 493 & $>50$ & Olhers & Others & 4.7 & $8-10$ & 0 & $0.61(0.50-0.75)$ & $0.38(0.26-0.56)$ & $0.16(0.08-0.33)$ & $19(11-26)$ \\
\hline 494 & $>50$ & Others & Others & $4-7$ & $8-10$ & $1-3$ & $0.53(0.41-0.68)$ & $0.29(0.18-0.46)$ & $0.09(0.04-0.23)$ & $14(9-19)$ \\
\hline 495 & $>50$ & Others & Others & $4-7$ & $8-10$ & 4.7 & $0.44(0.31-0.63)$ & $0.20(0.10-0.40)$ & $0.05(0.01-0.17)$ & $11(7-16)$ \\
\hline 496 & $>50$ & Others & Others & 4.7 & $8-10$ & 8.10 & $0.52(0.38-0.71)$ & $0.28(0.15-0.51)$ & $0.09(0.03-0.27)$ & $14(8-20)$ \\
\hline 497 & $>50$ & Others & Others & $8-10$ & 0 & 0 & $0.63(0.47-0.84)$ & $0.40(0.23-0.70)$ & $0.18(0.06-0.51)$ & $19(8-31)$ \\
\hline 498 & $>50$ & Others & Others & $8-10$ & 0 & $1-3$ & $0.55(0.37-0.81)$ & $0.31(0.14 \cdot 0.67)$ & $0.11(0.02-0.46)$ & $15(6-26)$ \\
\hline 499 & $>50$ & Others & Others & $8-10$ & 0 & $4-7$ & $0.46(0.27-0.77)$ & $0.22(0.08-0.60)$ & $0.06(0.01-0.38)$ & $12(5-19)$ \\
\hline 500 & $>50$ & Others & Others & $8-10$ & 0 & $8-10$ & $0.54(0.34-0.85)$ & $0.30(0.12-0.72)$ & $0.10(0.02-0.54)$ & $14(5-26)$ \\
\hline 501 & $>50$ & Others & Others & $8-10$ & $1-3$ & 0 & $0.56(0.42-0.74)$ & $0.32(0.18-0.56)$ & $0.11(0.04-0.33)$ & $15(8-23)$ \\
\hline 502 & $>50$ & Others & Others & $8-10$ & $1-3$ & $1+3$ & $0.47(032-0.69)$ & $0.23(0.11-0.48)$ & $0.06(0.01-0.25)$ & $12(6-18)$ \\
\hline 503 & $>50$ & Others & Others & $8-10$ & 1.3 & 4.7 & $0.38(0.23-0.63)$ & $0.15(0.06-0.40)$ & $0.03(0.00-0.18)$ & $10(5-14)$ \\
\hline 504 & $>50$ & Others & Others & $8-10$ & $1-3$ & 8.10 & $0.46(0.29-0.73)$ & $022(0.09 \cdot 0.53)$ & $0.06(0.01-0.31)$ & $12(6-19)$ \\
\hline 505 & $>50$ & Others & Others & $8-10$ & $4-7$ & 0 & $0.46(033-0.65)$ & $0.22(0.12-0.43)$ & $0.06(0.02-0.20)$ & $12(7-17)$ \\
\hline 506 & $>50$ & Others & Others & $8-10$ & $4-7$ & $1-3$ & $0.37(0.24-0.57)$ & $014(0.06-0.33)$ & $0.02(0.00-0.12)$ & $9(6.13)$ \\
\hline 507 & $>50$ & Others & Others & $8-10$ & $4-7$ & $4-7$ & $0.28(0.15 .0 .50)$ & $0.08(0.03-0.26)$ & $0.01(0.00-0.08)$ & $8(4.11)$ \\
\hline 508 & $>50$ & Others & Others & $8 \cdot 10$ & 4.7 & 8.10 & $0.36(0.21-0.63)$ & $014(0.05-0.41)$ & $0.02(0.00-0.18)$ & $9(5-14)$ \\
\hline 509 & $>50$ & Others & Others & $8-10$ & $8-10$ & 0 & $0.43(0.29-0.62)$ & 0.19 (0 09-0 39) & $0.04(0.01-0.17)$ & $11(6-15)$ \\
\hline 510 & $>50$ & Others & Others & $8-10$ & $8-10$ & 1.3 & $0.33(020-0.53)$ & $0.11(0.04-0.29)$ & $0.02(0.00-0.10)$ & $9(5-12)$ \\
\hline 511 & $>50$ & Others & Others & $8-10$ & $8-10$ & $4 \cdot 7$ & $0.24(0.13-0.45)$ & $0.06(0.02-0.21)$ & $0.00(0.00-0.05)$ & $7(4-10)$ \\
\hline 512 & $>50$ & Others & Others & 8.10 & $8-10$ & 8.10 & $0.32(0.18-0.56)$ & $0.11(0.04-0.32)$ & $0.01(0.00-0.12)$ & $8(5-13)$ \\
\hline
\end{tabular}


Appendix 4

Prognostic Index/ Nomogram: Predicted Survival Probability

\begin{tabular}{|c|c|c|c|c|c|c|c|c|c|c|}
\hline Scenario & $\begin{array}{l}\text { KPS } \\
\text { Score }\end{array}$ & $\begin{array}{l}\text { Primary Cancer } \\
\text { Sile }\end{array}$ & $\begin{array}{c}\text { Sile of } \\
\text { Metastases }\end{array}$ & $\begin{array}{l}\text { Appelite } \\
\text { Score }\end{array}$ & $\begin{array}{c}\text { Fatigue } \\
\text { Score }\end{array}$ & $\begin{array}{l}\text { Shortness of } \\
\text { Breath Score }\end{array}$ & $\begin{array}{c}\text { Predicted Survival } \\
\text { Probability at } 3 \text { months } \\
\text { (95\% CI) }\end{array}$ & $\begin{array}{l}\text { Predicted Survival } \\
\text { Probability at } 6 \text { months } \\
\text { (95\% Cl) }\end{array}$ & $\begin{array}{l}\text { Predicted Survival } \\
\text { Probability at } 1 \text { year } \\
(95 \% \mathrm{Cl})\end{array}$ & $\begin{array}{c}\text { Median } \\
\text { Survival in } \\
\text { weeks } \\
(95 \% \mathrm{Cl})\end{array}$ \\
\hline 513 & $\leq 50$ & Breast & Bone Only & 0 & 0 & 0 & $0.90(0.83-0.97)$ & $0.81(0.70-0.94)$ & $0.67(0.50-0.88)$ & \\
\hline 514 & $\mathbf{s} 50$ & Breast & Bone Only & 0 & 0 & 1.3 & $0.87(0.78 .0 .97)$ & $0.76(0.62-0.93)$ & $0.59(0.40-0.87)$ & $70(17-)$ \\
\hline 515 & $\leq 50$ & Breast & Bone Only & 0 & 0 & $4-7$ & $0.84(0.73-0.96)$ & $0.70(0.54-0.92)$ & $0.51(0.31-0.85)$ & $53(13-)$ \\
\hline 516 & $s 50$ & Breast & Bone Only & 0 & 0 & $8-10$ & $0.87(0.77-0.98)$ & $0.76(0.60-0.95)$ & $0.58(0.38-0.91)$ & $70(12-)$ \\
\hline 517 & $\leq 50$ & Breast & Bone Only & 0 & $1-3$ & 0 & $0.87(0.81-0.94)$ & $0.77(0.66-0.89)$ & $0.60(0.46-0.79)$ & $72(31-)$ \\
\hline 518 & $\leq 50$ & Breast & Bone Only & 0 & $1-3$ & $1-3$ & $0.84(0.76-0.93)$ & $0.71(0.58-0.86)$ & $0.52(0.36 \cdot 0.75)$ & $55(22-93)$ \\
\hline 519 & $\leq 50$ & Breast & Bone Only & 0 & $1-3$ & 4.7 & $0.80(0.70-0.91)$ & $0.64(0.50-0.83)$ & $0.43(0.26 \cdot 0.70)$ & $40(16-70)$ \\
\hline 520 & $\mathbf{s 5 0}$ & Breast & Bone Only & 0 & $1 \cdot 3$ & $8-10$ & $0.84(0.74-0.94)$ & $0.70(0.56-0.89)$ & $0.51(0.33-0.79)$ & $53(17-)$ \\
\hline 521 & $\leq 50$ & Breast & Bone Only & 0 & 4.7 & 0 & $0.84(0.76-0.93)$ & $0.71(0.58-0.86)$ & $0.51(0.35-0.74)$ & $54(21-93)$ \\
\hline 522 & $\leq 50$ & Breast & Bone Only & 0 & $4-7$ & $1 \cdot 3$ & $0.79(0.70-0.90)$ & $0.64(0.50-0.81)$ & $0.42(0.26-0.67)$ & $39(18-63)$ \\
\hline 523 & $\leq 50$ & Breast & Bone Only & 0 & $4-7$ & $4-7$ & $0.74(0.62-0.89)$ & $0.56(0.40-0.79)$ & $0.33(0.17-0.63)$ & $30(13.52)$ \\
\hline 524 & $\leq 50$ & Breast & Bone Only & 0 & 4.7 & $8-10$ & $0.79(0.67 .093)$ & $0.63(0.46-0.86)$ & $0.41(0.23-0.74)$ & $38(13-70)$ \\
\hline 525 & $\leq 50$ & Breast & Bone Only & 0 & $8-10$ & 0 & $0.82(0.73-0.92)$ & $0.68(0.54-0.85)$ & $0.48(0.31 \cdot 0.73)$ & $49(19-83)$ \\
\hline 526 & $\leq 50$ & Breast & Bone Only & 0 & $8-10$ & $1-3$ & $0.77(0.66-0.90)$ & $0.60(0.45-0.81)$ & $0.38(0.22-0.66)$ & $35(15-62)$ \\
\hline 527 & $s 50$ & Breast & Bone Only & 0 & $8-10$ & $4-7$ & $0.72(059-0.88)$ & $0.52(0.35-0.77)$ & $0.29(0.14-0.61)$ & $27(11-47)$ \\
\hline 528 & $\mathbf{s 5 0}$ & Breast & Bone Only & 0 & $8-10$ & $8-10$ & $0.77(0.65-0.91)$ & $0.60(0.43-0.83)$ & $0.37(0.20-0.70)$ & $35(13-62)$ \\
\hline 529 & $s 50$ & Breast & Bone Only & 1.3 & 0 & 0 & $090(083-097)$ & $0.81(070-0.94)$ & $0.67(0.51-0.88)$ & \\
\hline 530 & $s 50$ & Breast & Bone Only & $1-3$ & 0 & $1-3$ & $0.87(0.79-0.96)$ & $0.76(0.63-0.92)$ & $0.59(0.41-0.85)$ & $71(20-)$ \\
\hline 531 & $s 50$ & Breast & Bone Only & $1-3$ & 0 & $4-7$ & $0.84(0.73-0.95)$ & $0.70(0.55-0.91)$ & $0.51(0.32 \cdot 0.83)$ & $54(14-)$ \\
\hline 532 & $\leq 50$ & Breast & Bone Only & $1-3$ & 0 & $8-10$ & $0.87(0.77-0.97)$ & $0.76(0.61-0.94)$ & $0.59(0.39-0.89)$ & $70(14-)$ \\
\hline 533 & $\leq 50$ & Breast & Bone Only & 1.3 & $1-3$ & 0 & $0.87(0.81-0.94)$ & $0.77(0.67-0.88)$ & $0.60(0.46-0.79)$ & $75(34-)$ \\
\hline 534 & $\leq 50$ & Breast & Bone Only & $1-3$ & $1-3$ & 1.3 & $0.84(0.77 \cdot 0.92)$ & $0.71(0.60-0.84)$ & $0.52(0.38-0.72)$ & $58(26-88)$ \\
\hline 535 & $\leq 50$ & Breast & Bone Only & $1-3$ & $1-3$ & 4.7 & $0.80(0.71 .0 .90)$ & $0.64(0.51-0.81)$ & $0.43(0.28-0.67)$ & $40(19-69)$ \\
\hline 536 & $\leq 50$ & Breast & Bone Only & $1-3$ & 1.3 & $8-10$ & $0.84(0.75-0.93)$ & $0.70(0.57-0.87)$ & $0.51(0.34-0.76)$ & $54(20-93)$ \\
\hline 537 & $\leq 50$ & Breast & Bone Only & $1-3$ & 4.7 & 0 & $0.84(0.76-0.92)$ & $0.71(0.59-0.85)$ & $0.51(0.36-0.73)$ & $54(25.88)$ \\
\hline 538 & $\leq 50$ & Breast & Bone Only & 1.3 & 4.7 & 1.3 & $0.79(071.089)$ & $0.64(0.52-0.79)$ & $0.42(0.28-0.63)$ & $39(20-62)$ \\
\hline 539 & $\leq 50$ & Breast & Bone Only & 1.3 & $4-7$ & $4-7$ & $074(0.64 .0 .87)$ & $0.56(0.42-0.75)$ & $0.33(0.19-0.58)$ & $30(15-49)$ \\
\hline 540 & $\leq 50$ & Breast & Bone Only & 1.3 & 4.7 & $8-10$ & $079(068.091)$ & $0.63(0.48-0.83)$ & $0.41(0.24-0.70)$ & $38(15-66)$ \\
\hline 541 & $\leq 50$ & Breast & Bone Only & $1-3$ & $8-10$ & 0 & $082(073.092)$ & $0.68(0.54-0.85)$ & $0.48(0.31-0.73)$ & $49(19-83)$ \\
\hline 542 & $\leq 50$ & Breast & Bone Only & $1-3$ & $8-10$ & $1-3$ & $0.77(0.67-0.89)$ & $0.61(0.46-0.79)$ & $0.38(0.23-0.63)$ & $35(16-60)$ \\
\hline 543 & $\leq 50$ & Breast & Bone Only & $1-3$ & $8-10$ & $4-7$ & $072(0.60-087)$ & $052(037-0.75)$ & $029(0.15-0.57)$ & $27(13-44)$ \\
\hline 544 & $\leq 50$ & Breast & Bone Only & $1-3$ & $8-10$ & $8-10$ & $0.77(0.65-0.90)$ & $0.60(0.44-0.81)$ & $0.37(0.21-0.67)$ & $35(14.60)$ \\
\hline
\end{tabular}


Appendix 4

Prognostic Index/ Nomogram: Predicted Survival Probability

\begin{tabular}{|c|c|c|c|c|c|c|c|c|c|c|}
\hline Scenario & $\begin{array}{l}\text { KPS } \\
\text { Score }\end{array}$ & $\begin{array}{l}\text { Primary Cancer } \\
\text { Site }\end{array}$ & $\begin{array}{c}\text { Site of } \\
\text { Metastases }\end{array}$ & $\begin{array}{l}\text { Appetite } \\
\text { Score }\end{array}$ & $\begin{array}{l}\text { Fatigue } \\
\text { Score }\end{array}$ & $\begin{array}{l}\text { Shortness of } \\
\text { Brealh Score }\end{array}$ & $\begin{array}{l}\text { Predicted Survival } \\
\text { Probability at } 3 \text { months } \\
\text { (95\% CI) }\end{array}$ & $\begin{array}{c}\text { Predicled Survival } \\
\text { Probability at } 6 \text { months } \\
(95 \% \mathrm{CI})\end{array}$ & $\begin{array}{c}\text { Predicted Survival } \\
\text { Probability at } 1 \text { year } \\
(95 \% \mathrm{Cl})\end{array}$ & $\begin{array}{l}\text { Median } \\
\text { Survival in } \\
\text { weeks } \\
(95 \% \mathrm{Cl})\end{array}$ \\
\hline 545 & $\leq 50$ & Breast & Bone Only & $4-7$ & 0 & 0 & $0.90(0.83-0.97)$ & $0.81(0.70-0.94)$ & $0.67(0.50-0.88)$ & \\
\hline 546 & $\$ 50$ & Breast & Bone Only & $4-7$ & 0 & 1.3 & $0.87(0.78-0.96)$ & $0.76(0.62-0.92)$ & $0.59(0.41-0.86)$ & $70(19-)$ \\
\hline 547 & $\leq 50$ & Breast & Bone Only & $4-7$ & 0 & 4.7 & $0.83(0.73-0.95)$ & $0.70(0.54-0.91)$ & $0.51(0.31-0.83)$ & $53(14-)$ \\
\hline 548 & $s 50$ & Breast & Bone Only & $4-7$ & 0 & $8-10$ & $0.87(0.77-0.97)$ & $0.75(0.60-0.94)$ & $0.58(0.38-0.89)$ & $70(14-)$ \\
\hline 549 & $\leq 50$ & Breast & Bone Only & 4.7 & $1-3$ & 0 & $0.87(0.81-0.94)$ & $0.77(0.67-0.88)$ & $0.60(0.46-0.78)$ & $72(34-)$ \\
\hline 550 & $\leq 50$ & Breast & Bone Only & $4-7$ & $1-3$ & 1.3 & $0.84(0.77-0.92)$ & $0.71(0.60-0.84)$ & $0.52(0.37-0.71)$ & $55(26-88)$ \\
\hline 551 & $\leq 50$ & Breast & Bone Only & $4-7$ & $1-3$ & $4-7$ & $0.80(0.71-0.90)$ & $0.64(0.51-0.81)$ & $0.43(0.28-0.66)$ & $39(19-63)$ \\
\hline 552 & $\leq 50$ & Breast & Bone Only & 4.7 & $1-3$ & $8-10$ & $0.83(0.75-0.93)$ & $0.70(0.57-0.87)$ & $0.51(0.34-0.76)$ & $53(20-93)$ \\
\hline 553 & $\leq 50$ & Breast & Bone Only & $4-7$ & $4-7$ & 0 & $0.84(0.76-0.92)$ & $0.70(0.59 \cdot 0.84)$ & $0.51(0.36-0.72)$ & $53(25-84)$ \\
\hline 554 & $\leq 50$ & Breast & Bone Only & $4-7$ & 4.7 & $1-3$ & $0.79(0.71-0.88)$ & $0.63(0.52-0.78)$ & $0.42(0.28-0.62)$ & $39(20-62)$ \\
\hline 555 & $\leq 50$ & Breast & Bone Only & $4-7$ & $4-7$ & $4-7$ & $0.74(0.64-0.86)$ & $0.56(0.42-0.75)$ & $0.33(0.19-0.57)$ & $30(15-49)$ \\
\hline 556 & $\leq 50$ & Breast & Bone Only & 4.7 & 4.7 & 8.10 & $0.79(0.68-0.91)$ & $0.63(0.48 \cdot 0.82)$ & $0.41(0.24-0.69)$ & $38(15-63)$ \\
\hline 557 & $\leq 50$ & Breast & Bone Only & 4.7 & $8-10$ & 0 & $0.82(0.73-0.92)$ & $0.68(0.55-0.84)$ & $0.47(0.32-0.71)$ & $49(20-80)$ \\
\hline 558 & $\leq 50$ & Breast & Bone Only & 4.7 & $8-10$ & $1-3$ & $0.77(0.68-0.88)$ & $0.60(0.47 \cdot 0.77)$ & $0.38(0.24-0.61)$ & $35(18-59)$ \\
\hline 559 & $\leq 50$ & Breast & Bone Only & 4.7 & $8-10$ & $4-7$ & $0.72(0.60-0.86)$ & $0.52(0.37-0.73)$ & $0.29(0.15-0.55)$ & $27(13-41)$ \\
\hline 560 & $\leq 50$ & Breast & Bone Only & $4-7$ & $8-10$ & $8-10$ & $0.77(0.66-0.89)$ & $0.60(0.44 \cdot 0.80)$ & $0.37(0.21-0.65)$ & $35(14-59)$ \\
\hline 561 & $\leq 50$ & Breast & Bone Only & $8-10$ & 0 & 0 & $0.83(0.72-0.95)$ & $0.69(0.53-0.90)$ & $0.49(0.30-0.81)$ & $52(14-)$ \\
\hline 562 & $\leq 50$ & Breast & Bone Only & $8 \cdot 10$ & 0 & $1-3$ & $0.78(0.65-0.94)$ & $0.62(0.44-0.88)$ & $0.40(0.20-0.78)$ & $36(10-70)$ \\
\hline 563 & $\leq 50$ & Breast & Bone Only & $8-10$ & 0 & 4.7 & $0.73(0.58-0.92)$ & $0.54(0.34-0.85)$ & $0.31(0.13-0.73)$ & $29(8-53)$ \\
\hline 564 & $\leq 50$ & Breast & Bone Only & $8-10$ & 0 & $8 \cdot 10$ & $0.78(0.64-0.95)$ & $0.61(0.41-0.90)$ & $0.39(0.18-0.82)$ & $36(8-71)$ \\
\hline 565 & $\leq 50$ & Breast & Bone Only & $8-10$ & 1.3 & 0 & $0.79(0.69-0.90)$ & $0.63(0.49-0.81)$ & $0.41(0.25-0.67)$ & $38(17-63)$ \\
\hline 566 & $\leq 50$ & Breast & Bone Only & $8-10$ & $1-3$ & 1.3 & $0.73(062-0.87)$ & $0.55(0.40-0.76)$ & $0.31(0.17-0.58)$ & $29(14-49)$ \\
\hline 567 & $\leq 50$ & Breası & Bone Only & $8-10$ & $1-3$ & 4.7 & $0.67(0.54-0.84)$ & $0.46(0.30-0.70)$ & $0.23(0.10-0.51)$ & $21(11-35)$ \\
\hline 568 & $\leq 50$ & Breast & Bone Only & 8.10 & $1-3$ & $8-10$ & $0.73(0.60-0.89)$ & $0.54(0.37-0.79)$ & $0.31(0.15-0.64)$ & $29(11-50)$ \\
\hline 569 & $\leq 50$ & Breas! & Bone Only & 8.10 & 4.7 & 0 & $0.73(0.62-0.87)$ & $0.54(0.39-0.75)$ & $0.31(0.16-0.58)$ & $29(13-48)$ \\
\hline 570 & $\leq 50$ & Breast & Bone Only & $8 \cdot 10$ & 4.7 & 1.3 & $0.67(054-0.82)$ & $0.45(0.30-0.67)$ & $0.22(0.10-0.46)$ & $21(11-34)$ \\
\hline 571 & $\leq 50$ & Breas! & Bone Only & $8-10$ & 4.7 & 4.7 & $0.59(0.45-0.78)$ & $0.36(0.21-0.61)$ & $0.14(0.05 \cdot 0.39)$ & $17(9-26)$ \\
\hline 572 & $\leq 50$ & Breast & Bone Only & $8 \cdot 10$ & 4.7 & $8-10$ & $0.66(0.51-0.85)$ & $0.44(0.27-0.72)$ & $0.21(0.08-0.54)$ & $20(9-35)$ \\
\hline 573 & $\mathbf{s} 50$ & Breast & Bone Only & $8-10$ & $8 \cdot 10$ & 0 & $0.71(0.59 .085)$ & $0.51(0.35 \cdot 0.72)$ & $0.27(0.14-0.54)$ & $26(13-39)$ \\
\hline 574 & $\leq 50$ & Breast & Bone Only & 8.10 & $8-10$ & 1.3 & $0.64(0.51-0.79)$ & $0.41(0.27-0.63)$ & $0.18(0.08 \cdot 0.42)$ & $19(11-30)$ \\
\hline 575 & $\leq 50$ & Breast & Bone Only & $8-10$ & $8-10$ & 4.7 & $056(0.42-0.75)$ & $0.32(0.18-0.56)$ & $0.11(0.04-0.33)$ & $15(8-23)$ \\
\hline 576 & $\leq 50$ & Breast & Bone Only & $8 \cdot 10$ & $8-10$ & $8-10$ & $0.63(0.49-0.81)$ & $0.40(0.25-0.66)$ & $0.18(0.07-0.45)$ & $19(9-30)$ \\
\hline
\end{tabular}


Appendix 4

\section{Prognostic Index/ Nomogram: Predicted Survival Probability}

\begin{tabular}{|c|c|c|c|c|c|c|c|c|c|c|}
\hline Scenario & $\begin{array}{l}\text { KPS } \\
\text { Score }\end{array}$ & $\begin{array}{c}\text { Primary Cancer } \\
\text { Site }\end{array}$ & $\begin{array}{c}\text { Site of } \\
\text { Metastases }\end{array}$ & $\begin{array}{l}\text { Appetile } \\
\text { Score }\end{array}$ & $\begin{array}{c}\text { Fatigue } \\
\text { Score }\end{array}$ & $\begin{array}{l}\text { Shortness of } \\
\text { Breath Score }\end{array}$ & $\begin{array}{c}\text { Predicted Survival } \\
\text { Probability at } 3 \text { months } \\
(95 \% \mathrm{CI})\end{array}$ & $\begin{array}{c}\text { Predicted Survival } \\
\text { Probability at } 6 \text { months } \\
\text { (95\% Cl) }\end{array}$ & $\begin{array}{l}\text { Predicted Survival } \\
\text { Probability at } 1 \text { year } \\
\text { (95\% Cl) }\end{array}$ & $\begin{array}{l}\text { Median } \\
\text { Survival in } \\
\text { weeks } \\
(95 \% \mathrm{CI})\end{array}$ \\
\hline 577 & $\leq 50$ & Breast & Others & 0 & 0 & 0 & $0.80(0.69-0.93)$ & $0.65(0.49 \cdot 0.86)$ & $0.43(0.25-0.75)$ & $40(14-75)$ \\
\hline 578 & $\leq 50$ & Breast & Others & $\mathbf{D}$ & 0 & $1-3$ & $0.75(0.61-0.92)$ & $0.57(0.38-0.84)$ & $0.34(0.16-0.7 ?)$ & $31(10-59)$ \\
\hline 579 & $\leq 50$ & Breast & Others & 0 & 0 & 4.7 & $0.69(0$ 53-0.90) & $0.48(0.29-0.82)$ & $0.25(0.09-0.68)$ & $24(7-41)$ \\
\hline 580 & $s 50$ & Breast & Olhers & 0 & 0 & $8-10$ & $0.74(0.59-0.94)$ & $0.56(0.36-0.88)$ & $0.33(0.14-0.78)$ & $30(7-60)$ \\
\hline 581 & $\leq 50$ & Breast & Others & 0 & 1.3 & 0 & $0.76(0.65 \cdot 0.87)$ & $0.58(0.44-0.76)$ & $0.35(0.21-0.59)$ & $33(16-52)$ \\
\hline 582 & $\leq 50$ & Breast & Others & 0 & $1-3$ & $1-3$ & $0.69(0.57-0.84)$ & $0.49(0.34-0.72)$ & $0.26(0.13-0.52)$ & $25(12-38)$ \\
\hline 583 & $\leq 50$ & Breast & Others & 0 & $1-3$ & $4-7$ & $0.63(0.48-0.81)$ & $0.40(0.24-0.66)$ & $0.17(0.07-0.46)$ & $19(9-30)$ \\
\hline 584 & $\leq 50$ & Breast & Others & 0 & $1-3$ & $8-10$ & $0.69(0.55-0.87)$ & $0.48(0.31-0.76)$ & $0.25(0.11-0.58)$ & $24(10-39)$ \\
\hline 585 & $\leq 50$ & Breast & Others & 0 & $4-7$ & 0 & $0.69(0.57-0.84)$ & $0.49(0.33-0.70)$ & $0.25(0.12-0.51)$ & $25(12-38)$ \\
\hline 586 & $\leq 50$ & Breasi & Olhers & 0 & $4-7$ & $1 \cdot 3$ & $0.62(0.48-0.79)$ & $0.39(0.24-0.63)$ & $0.17(0.07-0.42)$ & $19(10-29)$ \\
\hline 587 & $\leq 50$ & Breası & Others & 0 & $4-7$ & $4-7$ & $0.54(0.38-0.76)$ & $0.30(0.15-0.58)$ & $0.10(0.03-0.35)$ & $14(7-22)$ \\
\hline 588 & $\leq 50$ & Breas! & Others & 0 & $4-7$ & $8 \cdot 10$ & $0.61(0.45-0.83)$ & $0.38(0.21-0.70)$ & $0.16(0.05-0.50)$ & $19(7-30)$ \\
\hline 589 & $\leq 50$ & Breast & Others & 0 & $8-10$ & 0 & $0.66(0.53-0.83)$ & $0.45(0.29-0.69)$ & $0.21(0.10 .0 .48)$ & $20(11-34)$ \\
\hline 590 & $\leq 50$ & Breast & Others & 0 & $8-10$ & $1-3$ & $0.59(0.44-0.78)$ & $0.35(0.20-0.61)$ & $0.14(0.05-0.39)$ & $16(8-26)$ \\
\hline 591 & $\leq 50$ & Breast & Others & 0 & $8-10$ & 4.7 & $0.50(0.34-0.74)$ & $0.26(0.12 \cdot 0.55)$ & $0.08(0.02-0.32)$ & $13(6-20)$ \\
\hline 592 & $\leq 50$ & Breast & Others & 0 & $8-10$ & $8-10$ & $058(0.42-0.80)$ & $0.34(0.18-0.65)$ & $0.13(0.04-0.43)$ & $16(7-27)$ \\
\hline 593 & $s 50$ & Breast & Others & $1-3$ & 0 & 0 & $0.80(0.69 \cdot 0.92)$ & $0.65(0.49-0.85)$ & $0.44(0.26-0.74)$ & $40(15.72)$ \\
\hline 594 & $s 50$ & Breast & Others & $1-3$ & 0 & $1-3$ & $0.75(0.62-0.91)$ & $0.57(0.39-0.82)$ & $0.34(0.17-0.68)$ & $31(11-58)$ \\
\hline 595 & $\leq 50$ & Breast & Others & $1-3$ & 0 & $4-7$ & $0.69(0.54-0.89)$ & $0.48(0.30-0.79)$ & $0.25(0.10-0.63)$ & $24(8-41)$ \\
\hline 596 & $\leq 50$ & Breast & Others & 1.3 & 0 & $8-10$ & $0.74(0.60-0.93)$ & $0.56(0.37-0.86)$ & $0.33(0.15-0.74)$ & $31(9-60)$ \\
\hline 597 & $\leq 50$ & Breas! & Others & $1-3$ & $1-3$ & 0 & $0.76(0.66-0.87)$ & $0.58(0.45 \cdot 0.75)$ & $0.35(0.22-0.57)$ & $33(17-52)$ \\
\hline 598 & $s 50$ & Breast & Others & $1-3$ & $1-3$ & 1.3 & $0.70(0.59-0.83)$ & $0.49(0.36-0.68)$ & $0.26(0.14-0.47)$ & $25(14-36)$ \\
\hline 599 & $\leq 50$ & Breast & Others & $1-3$ & $1-3$ & 4.7 & $0.63(0.50-0.79)$ & $0.40(0.26-0.62)$ & $0.18(0.08-0.40)$ & $19(10-29)$ \\
\hline 600 & $\leq 50$ & Breast & Others & $1-3$ & $1-3$ & $8-10$ & $0.69(0.56-0.85)$ & $0.48(0.32-0.72)$ & $0.25(0.12 \cdot 0.54)$ & $24(11-38)$ \\
\hline 601 & $\leq 50$ & Breast & Others & $1-3$ & $4 \cdot 7$ & 0 & $069(0.58-0.83)$ & $0.49(0.35-0.68)$ & $0.25(0.13-0.48)$ & $25(13-36)$ \\
\hline 602 & $s 50$ & Breast & Others & $1-3$ & 4.7 & 1.3 & $0.62(0.50-0.76)$ & $0.39(0.27-0.58)$ & $0.17(0.08 \cdot 0.35)$ & $19(11-27)$ \\
\hline 603 & $\leq 50$ & Breast & Others & $1-3$ & 4.7 & $4-7$ & $0.54(041-072)$ & $0.30(0.17 \cdot 0.52)$ & $0.10(0.04-0.29)$ & $14(8.20)$ \\
\hline 604 & $\leq 50$ & Breast & Others & 1.3 & $4-7$ & $8 \cdot 10$ & $061(0.47-0.81)$ & $0.38(0.23-0.65)$ & $0.16(0.06 \cdot 0.44)$ & $19(9-29)$ \\
\hline 605 & $\leq 50$ & Breast & Others & $1-3$ & $8-10$ & 0 & $066(0.54 .082)$ & $0.45(030-0.68)$ & $0.22(0.10 \cdot 0.47)$ & $21(11-34)$ \\
\hline 606 & $\leq 50$ & Breast & Others & $1-3$ & 8.10 & $1-3$ & $0.59(0.46-0.76)$ & $0.35(0.22-0.58)$ & $0.14(0.05-0.35)$ & $17(9-26)$ \\
\hline 607 & $\leq 50$ & Breast & Others & 1.3 & $8-10$ & 4.7 & $0.51(0.36-0.71)$ & $0.26(0.14-0.51)$ & $0.08(0.02-0.27)$ & $13(7-19)$ \\
\hline 608 & $\leq 50$ & Breast & Others & 1.3 & 8.10 & $8-10$ & $0.58(0.43-0.78)$ & $0.35(0.20-0.61)$ & $0.13(0.04-0.39)$ & $16(8-26)$ \\
\hline
\end{tabular}


Appendix 4

Prognostic Index/ Nomogram: Predicted Survival Probability

\begin{tabular}{|c|c|c|c|c|c|c|c|c|c|c|}
\hline Scenario & $\begin{array}{l}\text { KPS } \\
\text { Score }\end{array}$ & $\begin{array}{c}\text { Primary Cancer } \\
\text { Site }\end{array}$ & $\begin{array}{c}\text { Site of } \\
\text { Metastases }\end{array}$ & $\begin{array}{l}\text { Appetite } \\
\text { Score }\end{array}$ & $\begin{array}{c}\text { Fatigue } \\
\text { Score }\end{array}$ & $\begin{array}{l}\text { Shortness of } \\
\text { Breath Score }\end{array}$ & $\begin{array}{l}\text { Predicled Survival } \\
\text { Probability at } 3 \text { months } \\
\text { (95\% CI) }\end{array}$ & $\begin{array}{c}\text { Predicled Survival } \\
\text { Probability at } 6 \text { months } \\
\text { (95\% CI) }\end{array}$ & $\begin{array}{l}\text { Predicted Survival } \\
\text { Probability at } 1 \text { year } \\
\text { (95\% CI) }\end{array}$ & $\begin{array}{l}\text { Median } \\
\text { Survival in } \\
\text { weeks } \\
(95 \% \mathrm{CI})\end{array}$ \\
\hline 609 & $\leq 50$ & Breast & Others & 4.7 & 0 & 0 & $0.80(0.69-0.93)$ & $0.65(0.49-0.86)$ & $0.43(0.25-0.74)$ & $40(14-75)$ \\
\hline 610 & $\leq 50$ & Breast & Others & $4-7$ & 0 & 1.3 & $0.75(0.61-0.91)$ & $0.57(0.39-0.83)$ & $0.34(0.16-0.69)$ & $31(11-58)$ \\
\hline 611 & $\leq 50$ & Breast & Others & 4.7 & 0 & 4.7 & $0.69(0.53-0.89)$ & $0.48(0.29-0.79)$ & $0.25(0.10-0.64)$ & $24(8-41)$ \\
\hline 612 & $\leq 50$ & Breast & Others & $4-7$ & 0 & 8.10 & $0.74(0.59-0.93)$ & $0.56(0.36-0.86)$ & $0.33(0.14-0.75)$ & $30(8-59)$ \\
\hline 613 & $\leq 50$ & Breast & Others & 4.7 & $1-3$ & 0 & $0.75(0.66 \cdot 0.86)$ & $0.58(0.45-0.74)$ & $0.35(0.22-0.56)$ & $33(17-51)$ \\
\hline 614 & $\leq 50$ & Breast & Others & $4-7$ & 1.3 & 1.3 & $0.69(0.59-0.82)$ & $0.49(0.36-0.67)$ & $0.26(0.14-0.46)$ & $25(14-36)$ \\
\hline 615 & $\leq 50$ & Breast & Others & $4-7$ & $1-3$ & 4.7 & $0.63(0.50-0.78)$ & $0.40(0.26-0.61)$ & $0.17(0.08 \cdot 0.39)$ & $19(11-29)$ \\
\hline 616 & $\leq 50$ & Breast & Others & $4-7$ & 1.3 & $8-10$ & $0.69(0.56 \cdot 0.85)$ & $0.48(0.32-0.72)$ & $0.25(0.12-0.53)$ & $24(11-38)$ \\
\hline 617 & $\leq 50$ & Breast & Others & $4-7$ & $4-7$ & 0 & $0.69(0.58-0.82)$ & $0.48(0.35-0.67)$ & $0.25(0.13-0.46)$ & $24(13-35)$ \\
\hline 618 & $\leq 50$ & Breast & Others & 4.7 & 4.7 & 1.3 & $0.62(0.51-0.75)$ & $0.39(0.27-0.57)$ & $0.16(0.08-0.34)$ & $19(12-27)$ \\
\hline 619 & $\leq 50$ & Breast & Others & $4-7$ & $4-7$ & 4.7 & $0.54(0.41-0.71)$ & $0.30(0.17-0.51)$ & $0.10(0.04-0.27)$ & $14(8-20)$ \\
\hline 620 & $\leq 50$ & Breast & Others & 4.7 & 4.7 & $8-10$ & $0.61(0.47-0.80)$ & $0.38(0.23-0.64)$ & $0.16(0.06-0.42)$ & $19(9-29)$ \\
\hline 621 & $\leq 50$ & Breast & Others & 4.7 & $8-10$ & 0 & $0.66(0.54-0.81)$ & $0.45(0.31-0.65)$ & $0.21(0.10-0.44)$ & $20(12-33)$ \\
\hline 622 & $\leq 50$ & Breast & Others & $4-7$ & $8-10$ & 1.3 & $0.59(0.46-0.74)$ & $0.35(0.22-0.55)$ & $0.13(0.06-0.31)$ & $16(10-24)$ \\
\hline 623 & $\leq 50$ & Breast & Others & $4-7$ & $8-10$ & $4-7$ & $0.50(0.37-0.69)$ & $0.26(0.14 \cdot 0.48)$ & $0.08(0.02-0.24)$ & $13(8-19)$ \\
\hline 624 & $\leq 50$ & Breast & Others & $4-7$ & $8-10$ & $8-10$ & $058(0.44-0.76)$ & $0.34(0.20-0.58)$ & $0.13(0.05-0.36)$ & $16(9-26)$ \\
\hline 625 & $\leq 50$ & Breast & Others & $8-10$ & 0 & 0 & $0.68(0.52-0.88)$ & $0.47(0.28-0.78)$ & $0.23(0.09-0.62)$ & $22(8-39)$ \\
\hline 626 & $\leq 50$ & Breast & Others & $8-10$ & 0 & 1.3 & $0.60(0.42 .086)$ & $0.37(0.18 \cdot 0.74)$ & $0.15(0.04-0.57)$ & $18(6-30)$ \\
\hline 627 & $\leq 50$ & Breast & Others & 8.10 & 0 & 4.7 & $0.52(0.33-0.83)$ & $0.28(0.11-0.68)$ & $0.09(0.02-0.49)$ & $14(5-23)$ \\
\hline 628 & $\leq 50$ & Breast & Others & $8-10$ & 0 & $8-10$ & $0.59(0.40-0.89)$ & $0.36(0.17-0.79)$ & $0.14(0.03-0.63)$ & $17(5-31)$ \\
\hline 629 & $s 50$ & Breast & Others & $8-10$ & $1-3$ & 0 & $0.61(0.47-0.79)$ & $0.38(0.23-0.63)$ & $0.16(0.06-0.42)$ & $19(9-29)$ \\
\hline 630 & $\leq 50$ & Breast & Others & $8 \cdot 10$ & 1.3 & 1.3 & $053(0.38-0.74)$ & $0.29(0.15-0.55)$ & $0.09(0.03-0.32)$ & $14(7-20)$ \\
\hline 631 & $\leq 50$ & Breast & Others & $8-10$ & 1.3 & 4.7 & $0.44(029.0 .68)$ & $0.20(0.09-0.46)$ & $0.05(0.01-0.23)$ & $11(6 \cdot 17)$ \\
\hline 632 & $\leq 50$ & Breast & Others & $8-10$ & $1-3$ & $8 \cdot 10$ & $0.52(0.35-0.77)$ & $028(0.13-0.59)$ & $0.09(0.02-0.37)$ & $14(6-21)$ \\
\hline 633 & $\leq 50$ & Breast & Others & $8-10$ & 4.7 & 0 & $0.52(0.37-0.73)$ & $0.28(0.15-0.54)$ & $0.09(0.03-0.31)$ & $14(7-20)$ \\
\hline 634 & $\leq 50$ & Breast & Others & $8-10$ & 4.7 & 1.3 & $043(0.29-0.64)$ & $0.19(0.09-0.42)$ & $0.04(0.01-0.20)$ & $11(6-16)$ \\
\hline 635 & $\leq 50$ & Breast & Others & $8-10$ & $4-7$ & 4.7 & $034(0.20-0.58)$ & $0.12(0.04-0.34)$ & $0.02(0.00-0.13)$ & $9(5-13)$ \\
\hline 636 & $\leq 50$ & Breast & Others & $8-10$ & 4.7 & $8-10$ & $042(0.26-0.70)$ & $0.19(0.07-0.49)$ & $0.04(0.01-0.26)$ & $11(5.16)$ \\
\hline 637 & $s 50$ & Breast & Others & 8.10 & $8-10$ & 0 & $0.49(0.34-0.69)$ & $0.24(0.12-0.48)$ & $0.07(0.02-0.25)$ & $13(7-19)$ \\
\hline 638 & $\leq 50$ & Breast & Olhers & $8-10$ & $8 \cdot 10$ & $1-3$ & $0.39(026-0.60)$ & $0.16(0.07-0.36)$ & $0.03(0.01-0.15)$ & $10(6-14)$ \\
\hline 639 & $\mathbf{s} 50$ & Breast & Others & $8-10$ & $8-10$ & 4.7 & $030(0.17-052)$ & $0.09(0.03-0.27)$ & $0.01(0.00-0.09)$ & $8(5-11)$ \\
\hline 640 & $\leq 50$ & Breast & Others & $8-10$ & $8 \cdot 10$ & $8-10$ & $038(0.24-062)$ & $015(0.06-0.39)$ & $0.03(0.00-0.17)$ & $10(6-14)$ \\
\hline
\end{tabular}


Appendix 4

Prognostic Index/ Nomogram: Predicted Survival Probability

\begin{tabular}{|c|c|c|c|c|c|c|c|c|c|c|}
\hline Scenario & $\begin{array}{l}\text { KPS } \\
\text { Score }\end{array}$ & $\begin{array}{l}\text { Primary Cancer } \\
\text { Site }\end{array}$ & $\begin{array}{c}\text { Site of } \\
\text { Metastases }\end{array}$ & $\begin{array}{l}\text { Appetite } \\
\text { Score }\end{array}$ & $\begin{array}{l}\text { Faligue } \\
\text { Score }\end{array}$ & $\begin{array}{l}\text { Shortness of } \\
\text { Breath Score }\end{array}$ & $\begin{array}{c}\text { Predicted Survival } \\
\text { Probability at } 3 \text { months } \\
(95 \% \mathrm{Cl})\end{array}$ & $\begin{array}{c}\text { Predicted Survival } \\
\text { Probability at } 6 \text { months } \\
(95 \% \mathrm{Cl})\end{array}$ & $\begin{array}{l}\text { Predicted Survival } \\
\text { Probability at } 1 \text { year } \\
\text { (95\% Cl) }\end{array}$ & $\begin{array}{l}\text { Median } \\
\text { Survival in } \\
\text { weeks } \\
(95 \% \mathrm{Cl})\end{array}$ \\
\hline 641 & $\leq 50$ & Prostate & Bone Only & 0 & 0 & 0 & $0.81(0.70-0.94)$ & $0.66(0.50-0.87)$ & $0.46(0.27-0.77)$ & $44(14-83)$ \\
\hline 642 & $s 50$ & Prostate & Bone Only & 0 & 0 & 1.3 & $0.76(0.62 .0 .93)$ & $0.59(0.40 .0 .87)$ & $0.36(0.17-0.76)$ & $34(9-62)$ \\
\hline 643 & $\leq 50$ & Prostale & Bone Only & 0 & 0 & 4.7 & $0.70(0.54-0.92)$ & $0.50(0.30-0.84)$ & $0.27(0.10-0.72)$ & $26(7-49)$ \\
\hline 644 & $s 50$ & Prostale & Bone Only & 0 & 0 & $8-10$ & $0.76(0.60-0.95)$ & $0.58(0.37-0.91)$ & $0.35(0.15-0.83)$ & $33(6-63)$ \\
\hline 645 & $\mathbf{s} 50$ & Prostate & Bone Only & 0 & $1-3$ & 0 & $0.77(0.67-0.88)$ & $0.60(0.46-0.77)$ & $0.37(0.23-0.60)$ & $35(17-55)$ \\
\hline 646 & $\$ 50$ & Prostate & Bone Only & 0 & $1-3$ & 1.3 & $0.71(0.59 \cdot 0.86)$ & $0.51(0.36-0.73)$ & $0.28(0.14-0.55)$ & $26(13-41)$ \\
\hline 647 & $\leq 50$ & Prostate & Bone Only & 0 & 1.3 & 4.7 & $0.64(0.50-0.83)$ & $0.42(0.26-0.69)$ & $0.19(0.08-0.49)$ & $20(9-33)$ \\
\hline 648 & $\leq 50$ & Prostate & Bone Only & 0 & 1.3 & 8.10 & $0.70(0.56-0.89)$ & $0.50(0.32-0.78)$ & $0.27(0.12-0.63)$ & $26(10-44)$ \\
\hline 649 & $s 50$ & Prostate & Bone Only & 0 & $4-7$ & 0 & $0.71(0.60-0.84)$ & $0.51(0.37-0.70)$ & $0.27(0.15 \cdot 0.51)$ & $26(13-39)$ \\
\hline 650 & $\leq 50$ & Prostate & Bone Only & 0 & $4-7$ & $1-3$ & $0.64(0.51-0.80)$ & $0.41(0.27-0.64)$ & $0.19(0.08-0.43)$ & $19(11-31)$ \\
\hline 651 & $\leq 50$ & Prostate & Bone Only & 0 & 4.7 & 4.7 & $0.56(0.41-0.77)$ & $0.32(0.17-0.59)$ & $0.11(0.04-0.37)$ & $15(8-24)$ \\
\hline 652 & $\leq 50$ & Prostate & Bone Only & 0 & 4.7 & 8.10 & $0.63(0.47-0.85)$ & $0.41(0.23-0.72)$ & $0.18(0.06 \cdot 0.53)$ & $19(7-33)$ \\
\hline 653 & $\leq 50$ & Proslate & Bone Only & 0 & $8-10$ & 0 & $068(0.55 \cdot 0.84)$ & $0.47(0.31-0.71)$ & $0.24(0.11 \cdot 0.51)$ & $23(11-36)$ \\
\hline 654 & $\leq 50$ & Prostate & Bone Only & 0 & $8-10$ & $1-3$ & $0.61(0.46-0.80)$ & $0.38(0.22-0.65)$ & $0.15(0.05-0.43)$ & $18(8-28)$ \\
\hline 655 & $\leq 50$ & Prostate & Bone Only & 0 & $8-10$ & $4-7$ & $0.52(0.36-0.77)$ & $028(0.14-0.59)$ & $0.09(0.02-0.37)$ & $14(6-21)$ \\
\hline 656 & $\mathbf{s} 50$ & Prostate & Bone Only & 0 & $8 \cdot 10$ & $8 \cdot 10$ & $0.60(0.43-0.83)$ & $0.37(0.19 \cdot 0.69)$ & $0.15(0.04-0.50)$ & $17(7-29)$ \\
\hline 657 & $\leq 50$ & Prostate & Bone Only & $1-3$ & 0 & 0 & $0.81(0.70-0.94)$ & $0.67(0.50-0.88)$ & $0.46(0.27-0.78)$ & $45(14-83)$ \\
\hline 658 & $\leq 50$ & Prostate & Bone Only & $1-3$ & 0 & 1.3 & $0.76(0.63-0.93)$ & $0.59(0.41-0.86)$ & $0.36(0.18-0.74)$ & $34(10-62)$ \\
\hline 659 & $\leq 50$ & Prostate & Bone Only & $1-3$ & 0 & $4-7$ & $0.71(0.55-0.91)$ & $0.51(0.31-0.83)$ & $0.27(0.11-0.70)$ & $26(8-49)$ \\
\hline 660 & $\leq 50$ & Prostate & Bone Only & 1.3 & 0 & $8-10$ & $0.76(0.61-0.95)$ & $0.58(0.38-0.90)$ & $0.35(0.16-0.81)$ & $34(7-63)$ \\
\hline 661 & $\leq 50$ & Prostate & Bone Only & $1-3$ & 1.3 & 0 & $0.77(0.67-0.88)$ & $0.60(0.46-0.78)$ & $0.38(0.23-0.61)$ & $35(17-59)$ \\
\hline 662 & $\leq 50$ & Prostate & Bone Only & $1-3$ & 1.3 & 1.3 & $0.71(0.60-0.85)$ & $0.51(0.37-0.72)$ & $0.28(0.15-0.53)$ & $26(13-40)$ \\
\hline 663 & $\leq 50$ & Prostate & Bone Only & 1.3 & 1.3 & 4.7 & $0.65(0.51-0.82)$ & $0.43(0.27-0.67)$ & $0.20(0.08 \cdot 0.46)$ & $20(10-33)$ \\
\hline 664 & $\leq 50$ & Prostate & Bone Only & $1-3$ & $1-3$ & $8-10$ & $0.71(0.57-0.88)$ & $0.51(0.33-0.77)$ & $0.27(0.12-0.60)$ & $26(10-41)$ \\
\hline 665 & $s 50$ & Prostate & Bone Only & $1-3$ & 4.7 & 0 & $0.71(0.60-0.84)$ & $0.51(0.37-0.70)$ & $0.27(0.15-0.51)$ & $26(14-39)$ \\
\hline 666 & $\leq 50$ & Proslate & Bone Only & $1-3$ & $4-7$ & $1-3$ & $0.64(0.52-0.78)$ & $0.42(0.28 \cdot 0.62)$ & $0.19(0.09-0.39)$ & $19(11-30)$ \\
\hline 667 & $\leq 50$ & Prostate & Bone Only & $1-3$ & 4.7 & $4-7$ & $0.56(0.42-0.75)$ & $0.32(0.19-0.56)$ & $0.12(0.04-0.33)$ & $16(9-24)$ \\
\hline 668 & $\leq 50$ & Prostate & Bone Only & $1-3$ & 4.7 & 8.10 & $0.63(0.48-0.83)$ & $0.41(0.24-0.70)$ & $0.18(0.06-0.50)$ & $19(8-31)$ \\
\hline 669 & $\leq 50$ & Prostate & Bone Only & $1-3$ & $8-10$ & 0 & $068(055-085)$ & $0.47(031-0.72)$ & $0.24(0.11-0.53)$ & $23(11-37)$ \\
\hline 670 & $\leq 50$ & Prostate & Bone Only & 1.3 & $8-10$ & $1-3$ & $0.61(046.080)$ & $0.38(022-0.63)$ & $0.15(0.06-0.41)$ & $18(9-28)$ \\
\hline 671 & $\leq 50$ & Prostate & Bone Only & $1-3$ & 8.10 & $4-7$ & $0.53(0.37-0.76)$ & $0.29(0.14-0.57)$ & $0.09(0.02-0.35)$ & $14(7-21)$ \\
\hline 672 & $\leq 50$ & Prostate & Bone Only & 1.3 & 8.10 & $8-10$ & $0.60(0.44 \cdot 0.83)$ & $0.37(0.20 \cdot 0.68)$ & $0.15(0.05-0.48)$ & $18(7-29)$ \\
\hline
\end{tabular}


Appendix 4

Prognostic Index/ Nomogram: Predicted Survival Probability

\begin{tabular}{|c|c|c|c|c|c|c|c|c|c|c|}
\hline Scenario & $\begin{array}{l}\text { KPS } \\
\text { Score }\end{array}$ & $\begin{array}{c}\text { Primary Cancer } \\
\text { Site }\end{array}$ & $\begin{array}{c}\text { Site of } \\
\text { Melastases }\end{array}$ & $\begin{array}{l}\text { Appelite } \\
\text { Score }\end{array}$ & $\begin{array}{l}\text { Fatigue } \\
\text { Score }\end{array}$ & $\begin{array}{l}\text { Shoriness of } \\
\text { Breath Score }\end{array}$ & $\begin{array}{c}\text { Predicted Survival } \\
\text { Probability at } 3 \text { months } \\
(95 \% \mathrm{Cl}) \\
0.81(0.70-0.94)\end{array}$ & $\begin{array}{c}\text { Predicted Survival } \\
\text { Probability at } 6 \text { months } \\
(95 \% \mathrm{Cl}) \\
0.66(0.50-0.89)\end{array}$ & $\begin{array}{c}\text { Predicted Survival } \\
\text { Probability at } 1 \text { year } \\
(95 \% \mathrm{CI}) \\
0.46(0.26-0.79)\end{array}$ & $\begin{array}{c}\text { Median } \\
\text { Survival in } \\
\text { weeks } \\
(95 \% \mathrm{Cl}) \\
44(13-83)\end{array}$ \\
\hline 674 & $\leq 50$ & Prostate & Bone Only & $4-7$ & 0 & 1.3 & $0.76(0.62-0.93)$ & $0.59(0.40 .0 .87)$ & $0.36(0.17-0.76)$ & $34(9-62)$ \\
\hline 675 & $\leq 50$ & Prostate & Bone Only & 4.7 & 0 & 4.7 & $0.70(0.54-0.92)$ & $0.50(0.30-0.84)$ & $0.27(0.10-0.72)$ & $26(7-49)$ \\
\hline 676 & $\leq 50$ & Proslate & Bone Only & $4-7$ & 0 & $8-10$ & $0.76(0.60-0.95)$ & $0.58(0.37-0.91)$ & $0.35(0.15-0.83)$ & $33(6-63)$ \\
\hline 677 & $\leq 50$ & Prostate & Bone Only & $4-7$ & 1.3 & 0 & $0.77(0.67-0.88)$ & $0.60(0.46-0.78)$ & $0.37(0.23-0.61)$ & $35(16-58)$ \\
\hline 678 & $\leq 50$ & Proslate & Bone Only & 4.7 & $1-3$ & $1-3$ & $0.71(0.59-0.85)$ & $0.51(0.36-0.72)$ & $0.28(0.14-0.53)$ & $26(13-40)$ \\
\hline 679 & $\leq 50$ & Prostate & Bone Only & $4-7$ & 1.3 & $4-7$ & $0.64(0.51 .0 .82)$ & $0.42(0.27-0.67)$ & $0.19(0.08-0.47)$ & $20(10-32)$ \\
\hline 680 & $\leq 50$ & Prostate & Bone Only & $4-7$ & $1-3$ & $8-10$ & $0.70(0.56-0.88)$ & $0.50(0.33-0.77)$ & $0.27(0.12-0.61)$ & $26(10-44)$ \\
\hline 681 & $\leq 50$ & Prostate & Bone Only & $4-7$ & $4-7$ & 0 & $0.71(0.60 .0 .84)$ & $0.51(0.37-0.70)$ & $0.27(0.15-0.50)$ & $26(14-38)$ \\
\hline 682 & $\leq 50$ & Prostate & Bone Only & $4-7$ & 4.7 & 1.3 & $0.64(0.52-0.78)$ & $0.41(0.28-0.61)$ & $0.18(0.09-0.39)$ & $19(11-30)$ \\
\hline 683 & $\leq 50$ & Prostate & Bone Only & 4.7 & 4.7 & 4.7 & $0.56(0.42-0.75)$ & $0.32(0.18-0.56)$ & $0.11(0.04-0.33)$ & $15(8-23)$ \\
\hline 684 & $\leq 50$ & Prostate & Bone Only & $4-7$ & $4-7$ & $8-10$ & $0.63(0.48-0.83)$ & $0.40(0.24-0.69)$ & $0.18(0.06-0.50)$ & $19(8-31)$ \\
\hline 685 & $\leq 50$ & Prostate & Bone Only & 4.7 & 8.10 & 0 & $0.68(0.55 .0 .84)$ & $0.47(0.31-0.70)$ & $0.23(0.11-0.51)$ & $23(11-36)$ \\
\hline 686 & $\leq 50$ & Prostale & Bone Only & 4.7 & $8 \cdot 10$ & 1.3 & $0.60(0.46 \cdot 0.79)$ & $0.37(0.23-0.62)$ & $0.15(0.06-0.40)$ & $18(9-27)$ \\
\hline 687 & $\leq 50$ & Prostate & Bone Only & 4.7 & $8-10$ & 4.7 & $0.52(0.37-0.75)$ & $0.28(0.14 \cdot 0.56)$ & $0.09(0.02-0.33)$ & $14(7-20)$ \\
\hline 688 & $\leq 50$ & Prostale & Bone Only & 4.7 & $8-10$ & $8-10$ & $0.60(044-0.82)$ & $0.37(0.20-0.67)$ & $0.15(0.05-0.46)$ & $17(7-28)$ \\
\hline 689 & $\leq 50$ & Prostate & Bone Only & $8-10$ & 0 & 0 & $0.69(0.53 .090)$ & $0.49(0.29-0.81)$ & $0.25(0.10-0.67)$ & $25(8-41)$ \\
\hline 690 & $\leq 50$ & Prostate & Bone Only & $8-10$ & 0 & $1-3$ & $0.62(0.43 .0 .89)$ & $0.39(0.20-0.79)$ & $0.17(0.04-0.63)$ & $19(6-35)$ \\
\hline 691 & $\leq 50$ & Prostate & Bone Only & $8-10$ & 0 & 4.7 & $0.54(0.34 .0 .86)$ & $0.30(0.12-0.74)$ & $0.10(0.02-0.56)$ & $14(4-26)$ \\
\hline 692 & $\leq 50$ & Prostale & Bone Only & $8-10$ & 0 & 8.10 & $061(0.41-0.92)$ & $0.38(0.18-0.84)$ & $0.16(0.04-0.72)$ & $19(4-35)$ \\
\hline 693 & $\leq 50$ & Prostate & Bone Only & $8-10$ & $1-3$ & 0 & $0.63(0.49-0.81)$ & $0.41(0.25-0.66)$ & $0.18(0.07-0.45)$ & $19(9-30)$ \\
\hline 694 & $\leq 50$ & Prostate & Bone Only & 8.10 & $1-3$ & $1-3$ & $055(0.39-0.76)$ & $0.31(0.16-0.59)$ & $0.11(0.03-0.36)$ & $15(7-23)$ \\
\hline 695 & $\leq 50$ & Prostate & Bone Only & $8-10$ & 1.3 & $4-7$ & $0.46(030-0.71)$ & $0.22(0.10-0.51)$ & $0.06(0.01-0.28)$ & $12(6-19)$ \\
\hline 696 & $s 50$ & Proslate & Bone Only & $8 \cdot 10$ & 1.3 & $8-10$ & $0.54(0.36-0.80)$ & $0.30(0.14-0.65)$ & $0.10(0.02-0.44)$ & $14(6-24)$ \\
\hline 697 & $s 50$ & Prostate & Bone Only & $8-10$ & $4-7$ & 0 & $0.54(0.40-0.74)$ & $0.30(0.17-0.55)$ & $0.10(0.03-0.33)$ & $15(8-22)$ \\
\hline 698 & $\leq 50$ & Proslate & Bone Only & $8-10$ & $4-7$ & $1-3$ & $0.45(031-0.67)$ & $0.21(0.10-0.45)$ & $0.05(0.01-0.22)$ & $12(6-17)$ \\
\hline 699 & $s 50$ & Prostate & Bone Only & $8-10$ & $4-7$ & 4.7 & $0.36(0.22-0.60)$ & $0.14(0.05-0.37)$ & $0.02(0.00-0.15)$ & $9(5-14)$ \\
\hline 700 & $\leq 50$ & Prostate & Bone Only & 8.10 & $4-7$ & $8-10$ & $0.44(0.27-0.73)$ & $0.21(008.0 .54)$ & $0.05(0.01-0.31)$ & $11(5.18)$ \\
\hline 701 & $s 50$ & Prostate & Bone Only & $8-10$ & $8 \cdot 10$ & 0 & $0.51(036-0.72)$ & $0.27(0.13-0.52)$ & $0.08(0.02-0.29)$ & $13(7-19)$ \\
\hline 702 & $\leq 50$ & Prostate & Bone Only & $8-10$ & $8-10$ & 1.3 & $041(027-0.64)$ & $0.18(0.08 .0 .42)$ & $0.04(0.01-0.19)$ & $11(6-16)$ \\
\hline 703 & $\leq 50$ & Prostate & Bone Only & $8-10$ & $8-10$ & 4.7 & $032(0.18-0.57)$ & $0.11(0.04-0.33)$ & $0.01(0.00 \cdot 0.13)$ & $8(5-13)$ \\
\hline 704 & $\leq 50$ & Prostate & Bone Only & $8-10$ & $8-10$ & $8-10$ & $0.41(0.24-0.68)$ & $0.17(0.06-0.47)$ & $0.03(0.00-0.24)$ & $10(5-16)$ \\
\hline
\end{tabular}




\section{Appendix 4}

Prognostic Index/ Nomogram: Predicted Survival Probability

\begin{tabular}{|c|c|c|c|c|c|c|c|c|c|c|}
\hline Scenario & $\begin{array}{l}\text { KPS } \\
\text { Score }\end{array}$ & $\begin{array}{c}\text { Primary Cancer } \\
\text { Site }\end{array}$ & $\begin{array}{c}\text { Site of } \\
\text { Metastases }\end{array}$ & $\begin{array}{l}\text { Appetile } \\
\text { Score }\end{array}$ & $\begin{array}{l}\text { Fatigue } \\
\text { Score }\end{array}$ & $\begin{array}{l}\text { Shortness of } \\
\text { Breath Score }\end{array}$ & $\begin{array}{c}\text { Predicted Survival } \\
\text { Probability at } 3 \text { months } \\
\text { (95\% Cl) }\end{array}$ & $\begin{array}{c}\text { Predicted Survival } \\
\text { Probability al } 6 \text { months } \\
\text { (95\% CI) }\end{array}$ & $\begin{array}{l}\text { Predicted Survival } \\
\text { Probability at } 1 \text { year } \\
\qquad(95 \% \mathrm{Cl})\end{array}$ & $\begin{array}{l}\text { Median } \\
\text { Survival in } \\
\text { weeks } \\
(95 \% \mathrm{Cl})\end{array}$ \\
\hline 705 & $s 50$ & Prostate & Others & 0 & 0 & 0 & $0.65(0.49-0.87)$ & $0.43(0.24-0.75)$ & $0.20(0.07-0.58)$ & $20(8-35)$ \\
\hline 706 & $\leq 50$ & Prostate & Others & 0 & 0 & $1-3$ & $0.57(0.38-0.86)$ & $0.33(0.15-0.74)$ & $0.12(0.03-0.57)$ & $16(5-28)$ \\
\hline 707 & $\leq 50$ & Prostate & Olhers & 0 & 0 & $4-7$ & $0.48(0.28 \cdot 0.84)$ & $0.24(0.08-0.70)$ & $0.07(0.01-0.51)$ & $13(3.21)$ \\
\hline 708 & $s 50$ & Proslate & Olhers & 0 & 0 & $8 \cdot 10$ & $0.56(0.35-0.90)$ & $0.32(0.13-0.81)$ & $0.12(0.02-0.67)$ & $16(3-29)$ \\
\hline 709 & $\leq 50$ & Prostate & Olhers & 0 & $1-3$ & 0 & $0.58(0.44-0.77)$ & $0.35(0.20-0.59)$ & $0.13(0.05-0.36)$ & $16(9-26)$ \\
\hline 710 & $\leq 50$ & Proslate & Others & 0 & 1.3 & 1.3 & $0.49(0.33-0.73)$ & $0.25(0.12-0.54)$ & $0.07(0.02-0.31)$ & $13(6-19)$ \\
\hline 711 & $\leq 50$ & Prostate & Others & 0 & $1-3$ & $4-7$ & $0.40(0.24-0.68)$ & $0.17(0.06-0.47)$ & $0.03(0.00-0.24)$ & $10(5-16)$ \\
\hline 712 & $s 50$ & Prostate & Others & 0 & $1-3$ & $8 \cdot 10$ & $0.48(0.30-0.78)$ & $0.24(0.10-0.61)$ & $0.07(0.01-0.39)$ & $13(5-20)$ \\
\hline 713 & $\leq 50$ & Prostate & Others & 0 & $4-7$ & 0 & $0.49(0.34-0.70)$ & $0.25(0.12-0.49)$ & $0.07(0.02-0.26)$ & $13(7-19)$ \\
\hline 714 & $\leq 50$ & Prostate & Others & 0 & $4-7$ & $1-3$ & $0.39(0.24-0.64)$ & $0.16(0.06-0.42)$ & $0.03(0.00-0.19)$ & $10(5-15)$ \\
\hline 715 & $\leq 50$ & Prostate & Others & 0 & $4-7$ & 4.7 & $0.30(0.15 \cdot 0.59)$ & $0.10(0.03-0.35)$ & $0.01(0.00-0.14)$ & $8(4-12)$ \\
\hline 716 & $\leq 50$ & Prostate & Others & 0 & $4-7$ & $8 \cdot 10$ & $0.39(0.21-0.72)$ & $0.15(0.05-0.51)$ & $0.03(0.00-0.28)$ & $10(4-16)$ \\
\hline 717 & $\leq 50$ & Prostate & Others & 0 & $8-10$ & 0 & $0.45(0.29-0.69)$ & $0.21(0.09-0.48)$ & $0.05(0.01 \cdot 0.25)$ & $12(6-18)$ \\
\hline 718 & $\leq 50$ & Prostate & Others & 0 & $8-10$ & $1-3$ & $0.35(0.20-0.64)$ & $0.13(0.04 .0 .41)$ & $0.02(0.00-0.18)$ & $9(5-14)$ \\
\hline 719 & $\leq 50$ & Prostate & Others & 0 & $8-10$ & $4-7$ & $0.26(0.12-0.58)$ & $0.07(0.02-0.34)$ & $0.01(0.00-0.13)$ & $7(3-12)$ \\
\hline 720 & $\leq 50$ & Prostate & Others & 0 & $8 \cdot 10$ & 8.10 & $0.35(0.18 .0 .68)$ & $0.13(0.03-0.46)$ & $0.02(0.00-0.23)$ & $9(3-14)$ \\
\hline 721 & $\leq 50$ & Prostate & Others & $1-3$ & 0 & 0 & $0.65(0.49-0.87)$ & $0.43(0.25 \cdot 0.76)$ & $0.20(0.07-0.58)$ & $20(7-35)$ \\
\hline 722 & $\leq 50$ & Prostate & Others & $1-3$ & 0 & $1-3$ & $0.57(0.38-0.85)$ & $0.33(0.15 \cdot 0.72)$ & $0.12(0.03 \cdot 0.53)$ & $16(6-27)$ \\
\hline 723 & $\leq 50$ & Prostate & Others & $1-3$ & 0 & 4.7 & $0.49(0.29 \cdot 0.82)$ & $0.24(0.09-0.68)$ & $0.07(0.01-0.47)$ & $13(4-20)$ \\
\hline 724 & $\leq 50$ & Prostate & Others & $1-3$ & 0 & $8-10$ & $0.56(0.36 .089)$ & $0.33(0.13-0.79)$ & $0.12(0.02-0.63)$ & $16(4-29)$ \\
\hline 725 & $s 50$ & Prostale & Others & $1-3$ & $1-3$ & 0 & $0.58(0.44-0.77)$ & $0.35(0.20-0.59)$ & $0.13(0.05-0.37)$ & $16(8-26)$ \\
\hline 726 & $\leq 50$ & Prostale & Others & 1.3 & $1-3$ & $1-3$ & $0.50(0.34-0.72)$ & $0.25(0.12-0.52)$ & $0.07(0.02 \cdot 0.28)$ & $13(7-19)$ \\
\hline 727 & $\leq 50$ & Prostale & Others & $1-3$ & $1-3$ & 4.7 & $0.41(0.25-0.66)$ & $0.17(0.07-0.44)$ & $0.03(0.01-0.21)$ & $10(5-15)$ \\
\hline 728 & $\leq 50$ & Prostate & Others & $1-3$ & 1.3 & $8-10$ & $0.49(0.31 .0 .76)$ & $0.24(0.10-0.58)$ & $0.07(0.01-0.36)$ & $13(6-20)$ \\
\hline 729 & $\leq 50$ & Prostate & Others & $1-3$ & $4-7$ & 0 & $0.49(0.34-0.70)$ & $0.25(0.13-0.49)$ & $0.07(0.02-0.25)$ & $13(7-19)$ \\
\hline 730 & $\leq 50$ & Prostate & Others & $1-3$ & 4.7 & $1-3$ & $0.40(0.26 .0 .61)$ & $0.16(0.07-0.38)$ & $0.03(0.01-0.16)$ & $10(6-15)$ \\
\hline 731 & $\leq 50$ & Prostate & Others & 1.3 & $4-7$ & 4.7 & $0.30(0.17-0.55)$ & $0.10(0.03-0.31)$ & $0.01(0.00-0.11)$ & $8(4-12)$ \\
\hline 732 & $\leq 50$ & Prostate & Olhers & $1-3$ & 4.7 & $8-10$ & $039(0.22-0.69)$ & $0.16(0.05-0.47)$ & $0.03(0.00-0.24)$ & $10(4-15)$ \\
\hline 733 & $\leq 50$ & Proslate & Others & 1.3 & $8-10$ & 0 & $0.45(0.29 .0 .70)$ & $0.21(0.09-0.49)$ & $0.05(0.01-0.26)$ & $12(6-18)$ \\
\hline 734 & $\leq 50$ & Prostate & Others & 1.3 & $8-10$ & 1.3 & $0.36(0.20 .0 .62)$ & $0.13(0.05-0.39)$ & $0.02(0.00-0.16)$ & $9(5-14)$ \\
\hline 735 & $\leq 50$ & Prostate & Others & $1-3$ & $8-10$ & $4-7$ & $0.27(0.13 .0 .56)$ & $0.07(0.02-0.31)$ & $0.01(0.00-0.11)$ & $7(3-11)$ \\
\hline 736 & $\leq 50$ & Prostate & Others & $1-3$ & $8-10$ & $8-10$ & $0.35(0.18-0.66)$ & $0.13(0.04 .0 .44)$ & $0.02(0.00-0.21)$ & $9(4-14)$ \\
\hline
\end{tabular}


Appendix 4

Prognostic Index/ Nomogram: Predicted Survival Probability

\begin{tabular}{|c|c|c|c|c|c|c|c|c|c|c|}
\hline Scenario & $\begin{array}{l}\text { KPS } \\
\text { Score }\end{array}$ & $\begin{array}{c}\text { Primary Cancer } \\
\text { Site }\end{array}$ & $\begin{array}{c}\text { Site of } \\
\text { Metastases }\end{array}$ & $\begin{array}{l}\text { Appetite } \\
\text { Score }\end{array}$ & $\begin{array}{l}\text { Fatigue } \\
\text { Score }\end{array}$ & $\begin{array}{l}\text { Shortness of } \\
\text { Breath Score }\end{array}$ & $\begin{array}{c}\text { Predicted Survival } \\
\text { Probability at } 3 \text { months } \\
(95 \% \mathrm{Cl})\end{array}$ & $\begin{array}{c}\text { Predicted Survival } \\
\text { Probability at } 6 \text { months } \\
\text { (95\% CI) }\end{array}$ & $\begin{array}{c}\text { Predicted Survival } \\
\text { Probability at } 1 \text { year } \\
(95 \% \mathrm{CI})\end{array}$ & $\begin{array}{l}\text { Median } \\
\text { Survival in } \\
\text { weeks } \\
(95 \% \mathrm{Cl})\end{array}$ \\
\hline 737 & $\leq 50$ & Prostate & Others & $4-7$ & 0 & 0 & $0.65(0.48 .088)$ & $0.43(0.24-0.77)$ & $0.20(0.06-0.60)$ & $20(7-36)$ \\
\hline 738 & $\leq 50$ & Prostate & Others & $4-7$ & 0 & $1-3$ & $0.57(0.38-0.86)$ & $0.33(0.15-0.74)$ & $0.12(0.03-0.56)$ & $16(5-28)$ \\
\hline 739 & $\leq 50$ & Prostate & Others & $4-7$ & 0 & $4-7$ & $0.48(0.28-0.83)$ & $0.24(0.08-0.70)$ & $0.07(0.01-0.50)$ & $13(4-21)$ \\
\hline 740 & $\leq 50$ & Prostate & Others & $4-7$ & 0 & 8.10 & $0.56(0.35 .0 .90)$ & $0.32(0.13-0.81)$ & $0.11(0.02-0.66)$ & $15(3-28)$ \\
\hline 741 & $\leq 50$ & Prostale & Others & $4-7$ & $1-3$ & 0 & $0.58(0.44-0.77)$ & $0.34(0.20-0.59)$ & $0.13(0.05-0.36)$ & $16(8-26)$ \\
\hline 742 & $s 50$ & Prostate & Others & $4-7$ & $1-3$ & 1.3 & $0.49(0.34-0.71)$ & $0.25(0.12-0.51)$ & $0.07(0.02-0.28)$ & $13(7-19)$ \\
\hline 743 & $\leq 50$ & Prostate & Others & 4.7 & 1.3 & $4-7$ & $0.40(0.24-0.66)$ & $0.17(0.06-0.44)$ & $0.03(0.01-0.21)$ & $10(5-15)$ \\
\hline 744 & $\leq 50$ & Prostate & Others & $4-7$ & $1-3$ & $8-10$ & $0.48(0.31-0.76)$ & $0.24(0.10-0.58)$ & $0.07(0.01-0.36)$ & $13(6-20)$ \\
\hline 745 & $\leq 50$ & Prostate & Others & $4-7$ & $4-7$ & 0 & $0.49(0.34-0.69)$ & $0.24(0.13-0.48)$ & $0.07(0.02-0.24)$ & $13(7-19)$ \\
\hline 746 & $\leq 50$ & Proslate & Others & $4-7$ & $4-7$ & $1-3$ & $0.39(0.25-0.61)$ & $0.16(0.07-0.37)$ & $0.03(0.01-0.15)$ & $10(6 \cdot 14)$ \\
\hline 747 & $\leq 50$ & Prostate & Others & $4-7$ & $4-7$ & $4-7$ & $0.30(0.16-0.55)$ & $0.10(0.03-0.31)$ & $0.01(0.00-0.11)$ & $8(4-12)$ \\
\hline 748 & $\leq 50$ & Prostate & Others & 4.7 & $4-7$ & 8.10 & $0.38(0.22-0.68)$ & $0.15(0.05-0.47)$ & $0.03(0.00-0.23)$ & $10(4-15)$ \\
\hline 749 & $\leq 50$ & Prostate & Olhers & $4-7$ & $8-10$ & 0 & $0.45(0.29-0.68)$ & $0.21(0.09-0.47)$ & $0.05(0.01-0.24)$ & $12(6-18)$ \\
\hline 750 & $\$ 50$ & Prostate & Others & $4-7$ & $8-10$ & 1.3 & $0.35(0.21-0.60)$ & $0.13(0.05-0.37)$ & $0.02(0.00-0.15)$ & $9(5-14)$ \\
\hline 751 & $\leq 50$ & Prostate & Others & 4.7 & $8-10$ & $4-7$ & $0.26(0.13-0.54)$ & $0.07(0.02-0.29)$ & $0.01(0.00-0.10)$ & $7(4-11)$ \\
\hline 752 & $\leq 50$ & Prostate & Others & 4.7 & $8-10$ & 8.10 & $0.34(0.18-0.65)$ & $0.12(0.04-0.42)$ & $0.02(0.00-0.19)$ & $9(4-14)$ \\
\hline 753 & $\leq 50$ & Prostate & Others & $8-10$ & 0 & 0 & $0.47(0.27-0.81)$ & $0.23(0.08-0.65)$ & $0.06(0.01-0.45)$ & $12(4-20)$ \\
\hline 754 & $\leq 50$ & Prostate & Others & $8 \cdot 10$ & 0 & 1.3 & $0.37(0.18-0.79)$ & $0.14(0.03-0.62)$ & $0.02(0.00-0.41)$ & $9(3-16)$ \\
\hline 755 & $\leq 50$ & Prostate & Others & $8-10$ & 0 & $4-7$ & $028(0.11-0.74)$ & $0.08(0.01 \cdot 0.55)$ & $0.01(0.00-0.32)$ & $8(2-13)$ \\
\hline 756 & $\leq 50$ & Prostate & Others & $8-10$ & 0 & $8-10$ & $0.36(0.16-0.84)$ & $0.14(0.03-0.71)$ & $0.02(0.00-0.52)$ & $9(2-16)$ \\
\hline 757 & $\leq 50$ & Prostate & Others & $8-10$ & 1.3 & 0 & $0.38(0.22-0.66)$ & $0.15(0.05-0.44)$ & $0.03(0.00-0.21)$ & $10(5 \cdot 15)$ \\
\hline 758 & $\leq 50$ & Prostate & Others & $8 \cdot 10$ & 1.3 & $1-3$ & $0.29(0.14-0.60)$ & $0.09(0.02-0.36)$ & $0.01(0.00-0.15)$ & $8(3-12)$ \\
\hline 759 & $\leq 50$ & Prostale & Others & $8-10$ & 1.3 & 4.7 & $0.20(0.08-0.51)$ & $0.04(0.01-0.27)$ & $0.00(000-0.09)$ & $6(3-10)$ \\
\hline 760 & $\leq 50$ & Prostale & Others & $8-10$ & $1-3$ & $8-10$ & $0.28(0.12-0.65)$ & $0.08(0.02-0.43)$ & $0.01(0.00 \cdot 0.20)$ & $8(3-12)$ \\
\hline 761 & $\leq 50$ & Prostate & Others & $8-10$ & 4.7 & 0 & $0.28(0.15-0.55)$ & $0.09(0.02-0.31)$ & $0.01(0.00-0.11)$ & $8(4-12)$ \\
\hline 762 & $\leq 50$ & Prostate & Others & 8.10 & 4.7 & $1-3$ & $0.19(0.08-0.46)$ & $0.04(0.01-0.22)$ & $0.00(0.00-0.06)$ & $6(3-9)$ \\
\hline 763 & $\leq 50$ & Prostate & Others & $8-10$ & $4-7$ & 4.7 & $012(0.04-0.38)$ & $0.02(0.00-0.15)$ & $0.00(0.00-0.03)$ & $5(3-7)$ \\
\hline 764 & $\leq 50$ & Prostate & Others & 8-10 & $4-7$ & $8-10$ & $019(0.07-0.54)$ & $0.04(0.00-0.29)$ & $0.00(0.00-0.10)$ & $6(3-9)$ \\
\hline 765 & $\leq 50$ & Prostate & Others & $8-10$ & $8-10$ & 0 & $0.25(0.12 .0 .52)$ & $0.06(0.02-0.27)$ & $0.01(0.00-0.09)$ & $7(3-11)$ \\
\hline 766 & $\$ 50$ & Prostate & Others & $8 \cdot 10$ & $8-10$ & 1.3 & $0.16(0.06-0.42)$ & $0.03(0.00-0.18)$ & $0.00(0.00-0.04)$ & $6(3-8)$ \\
\hline 767 & $\leq 50$ & Prostate & Others & $8-10$ & $8-10$ & $4-7$ & $0.10(0.03-0.33)$ & $0.01(0.00-0.11)$ & $0.00(0.00-0.02)$ & $5(2-7)$ \\
\hline 768 & $\leq 50$ & Prostate & Others & $8 \cdot 10$ & $8-10$ & $8-10$ & $0.16(0.05-0.46)$ & $0.03(0.00-0.21)$ & $0.00(0.00-0.06)$ & $6(3-8)$ \\
\hline
\end{tabular}


Appendix 4

Prognostic Index/ Nomogram: Predicted Survival Probability

\begin{tabular}{|c|c|c|c|c|c|c|c|c|c|c|}
\hline Scenario & $\begin{array}{l}\text { KPS } \\
\text { Score }\end{array}$ & $\begin{array}{l}\text { Primary Cancer } \\
\text { Site }\end{array}$ & $\begin{array}{c}\text { Site of } \\
\text { Metastases }\end{array}$ & $\begin{array}{l}\text { Appetile } \\
\text { Score }\end{array}$ & $\begin{array}{c}\text { Fatigue } \\
\text { Score }\end{array}$ & $\begin{array}{l}\text { Shortness of } \\
\text { Breath Score }\end{array}$ & $\begin{array}{c}\text { Predicted Survival } \\
\text { Probability at } 3 \text { months } \\
(95 \% \mathrm{CI}) \\
0.80(0.68-0.93)\end{array}$ & $\begin{array}{c}\text { Predicted Survival } \\
\text { Probability at } 6 \text { months } \\
(95 \% \mathrm{Cl}) \\
0.64(0.47-0.87)\end{array}$ & $\begin{array}{c}\text { Predicted Survival } \\
\text { Probability at } 1 \text { year } \\
(95 \% \text { CI) } \\
0.43(0.24-0.76)\end{array}$ & $\begin{array}{c}\text { Median } \\
\text { Survival in } \\
\text { weeks } \\
(95 \% \mathrm{Cl}) \\
40(13-80)\end{array}$ \\
\hline 770 & $\leq 50$ & Lung & Bone Only & 0 & 0 & $1-3$ & $0.75(0.60-0.92)$ & $0.56(0.37-0.85)$ & $0.33(0.15-0.74)$ & $31(9-59)$ \\
\hline 771 & $\leq 50$ & Lung & Bone Only & 0 & 0 & $4-7$ & $0.69(0.52-0.91)$ & $0.48(0.28-0.82)$ & $0.24(0.09-0.69)$ & $24(7-41)$ \\
\hline 772 & $\leq 50$ & Lung & Bone Only & 0 & 0 & 8.10 & $0.74(0.58-0.94)$ & $0.56(0.35-0.89)$ & $0.32(0.13-0.80)$ & $30(7-60)$ \\
\hline 773 & $\leq 50$ & Lung & Bone Only & 0 & 1.3 & 0 & $0.75(065-0.88)$ & $0.57(0.43-0.77)$ & $0.35(0.20-0.60)$ & $32(15-52)$ \\
\hline 774 & $\leq 50$ & Lung & Bone Only & 0 & $1-3$ & $1-3$ & $0.69(0.57-0.84)$ & $0.49(0.33-0.71)$ & $0.25(0.12-0.53)$ & $25(12-38)$ \\
\hline 775 & $\leq 50$ & Lung & Bone Only & 0 & $1-3$ & $4-7$ & $0.62(0.48-0.81)$ & $0.40(0.24-0.66)$ & $0.17(0.06-0.46)$ & $19(9-30)$ \\
\hline 776 & $\leq 50$ & Lung & Bone Only & 0 & $1-3$ & 8.10 & $069(0.54-0.87)$ & $0.48(0.30-0.76)$ & $0.24(0.10-0.59)$ & $24(9.39)$ \\
\hline 777 & $\leq 50$ & Lung & Bone Only & 0 & $4-7$ & 0 & $0.69(0.57-0.83)$ & $0.48(0.33-0.70)$ & $0.25(0.12-0.50)$ & $24(12-36)$ \\
\hline 778 & $\leq 50$ & Lung & Bone Only & $\mathbf{0}$ & $4-7$ & 1.3 & $0.61(0.48-0.78)$ & $0.39(0.24-0.62)$ & $0.16(0.07 \cdot 0.40)$ & $19(10-28)$ \\
\hline 779 & $\leq 50$ & Lung & Bone Only & 0 & 4.7 & $4-7$ & $0.54(0.38-0.75)$ & $0.29(0.15-0.56)$ & $0.10(0.03-0.34)$ & $14(7-21)$ \\
\hline 780 & $\leq 50$ & Lung & Bone Only & 0 & $4-7$ & $8 \cdot 10$ & $0.61(0.45-0.83)$ & $0.38(0.21-0.68)$ & $0.16(0.05-0.49)$ & $18(7-29)$ \\
\hline 781 & $\leq 50$ & Lung & Bone Only & 0 & 8.10 & 0 & $0.66(0.52-0.84)$ & $0.44(0.28-0.70)$ & $0.21(0.09-0.51)$ & $20(10-35)$ \\
\hline 782 & $\leq 50$ & Lung & Bone Only & 0 & $8 \cdot 10$ & 1.3 & $0.58(0.43-0.79)$ & $0.35(0.19-0.63)$ & $0.13(0.04-0.41)$ & $16(8-26)$ \\
\hline 783 & $\leq 50$ & Lung & Bone Only & 0 & $8-10$ & $4-7$ & $0.50(0.33-0.75)$ & $0.26(0.12-0.56)$ & $0.07(0.02-0.34)$ & $13(6-20)$ \\
\hline 784 & $s 50$ & Lung & Bone Only & 0 & $8-10$ & $8-10$ & $0.57(0.41-0.81)$ & $0.34(0.17-0.66)$ & $0.13(0.03-0.46)$ & $16(7-27)$ \\
\hline 785 & $\leq 50$ & Lung & Bone Only & $1-3$ & 0 & 0 & $0.80(0.68-0.93)$ & $064(0.48-0.87)$ & $0.43(0.24-0.77)$ & $40(13-80)$ \\
\hline 786 & $\leq 50$ & Lung & Bone Only & $1 \cdot 3$ & 0 & $1-3$ & $0.75(0.61-0.92)$ & $0.56(0.38-0.84)$ & $0.34(0.16-0.71)$ & $31(10-59)$ \\
\hline 787 & $\leq 50$ & Lung & Bone Only & 1.3 & 0 & $4-7$ & $0.69(0.53-0.90)$ & $0.48(0.29-0.81)$ & $0.25(0.09-0.66)$ & $24(8-41)$ \\
\hline 788 & $\leq 50$ & Lung & Bone Only & 1.3 & 0 & $8-10$ & $0.74(0.59-0.94)$ & $0.56(0.36 .087)$ & $0.33(0.14-0.77)$ & $30(7-59)$ \\
\hline 789 & $\leq 50$ & Lung & Bone Only & $1-3$ & 1.3 & 0 & $0.75(0.65-0.88)$ & $0.58(0.43-0.77)$ & $0.35(0.20-0.60)$ & $33(15-52)$ \\
\hline 790 & $\leq 50$ & Lung & Bone Only & $1-3$ & $1-3$ & $1-3$ & $0.69(0.58-0.83)$ & $0.49(0.34-0.69)$ & $0.25(0.13-0.50)$ & $25(13-36)$ \\
\hline 791 & $s 50$ & Lung & Bone Only & $1-3$ & $1-3$ & 4.7 & $062(0.49-0.80)$ & $0.40(0.25-0.64)$ & $0.17(0.07 \cdot 0.42)$ & $19(10-29)$ \\
\hline 792 & $\mathbf{s 5 0}$ & Lung & Bone Only & 1.3 & 1.3 & $8 \cdot 10$ & $0.69(0.55-0.86)$ & $0.48(0.31-0.74)$ & $0.25(0.11-0.56)$ & $24(10-38)$ \\
\hline 793 & $\leq 50$ & Lung & Bone Only & 1.3 & 4.7 & 0 & $0.69(0.57-0.83)$ & $0.48(0.34-0.69)$ & $0.25(0.12-0.49)$ & $24(13-36)$ \\
\hline 794 & $s 50$ & Lung & Bone Only & $1-3$ & 4.7 & $1-3$ & $062(0.50-0.76)$ & $0.39(0.26-0.58)$ & $0.16(0.07-0.36)$ & $19(11-27)$ \\
\hline 795 & $\leq 50$ & Lung & Bone Only & $1-3$ & 4.7 & 4.7 & $0.54(0.40-0.72)$ & $0.30(0.17-0.52)$ & $0.10(0.03-0.29)$ & $14(8-20)$ \\
\hline 796 & $\leq 50$ & Lung & Bone Only & $1-3$ & 4.7 & $8-10$ & $0.61(0.46-0.81)$ & $0.38(0.22-0.65)$ & $0.16(0.06-0.44)$ & $18(8-28)$ \\
\hline 797 & $\leq 50$ & Lung & Bone Only & 1.3 & $8 \cdot 10$ & 0 & $0.66(0.52 .0 .84)$ & $0.44(0.28-0.71)$ & $0.21(0.09-0.52)$ & $20(10.35)$ \\
\hline 798 & $\mathbf{s} 50$ & Lung & Bone Only & $1-3$ & $8-10$ & $1-3$ & $0.58(0.44-0.78)$ & $0.35(0.20-0.61)$ & $0.13(0.05-0.39)$ & $16(8-26)$ \\
\hline 799 & $\leq 50$ & Lung & Bone Only & $1-3$ & $8-10$ & 4.7 & $0.50(034-0.73)$ & $0.26(0.12-0.54)$ & $0.08(0.02-0.31)$ & $13(6-20)$ \\
\hline 800 & $\leq 50$ & Lung & Bone Only & $1-3$ & $8-10$ & $8-10$ & $0.58(0.42-080)$ & $0.34(0.18-0.64)$ & $0.13(0.04-0.43)$ & $16(7-26)$ \\
\hline
\end{tabular}


Appendix 4

Prognostic Index/ Nomogram: Predicted Survival Probability

\begin{tabular}{|c|c|c|c|c|c|c|c|c|c|c|}
\hline Scenario & $\begin{array}{l}\text { KPS } \\
\text { Score }\end{array}$ & $\begin{array}{l}\text { Primary Cancer } \\
\text { Site }\end{array}$ & $\begin{array}{c}\text { Site of } \\
\text { Metastases }\end{array}$ & $\begin{array}{l}\text { Appetile } \\
\text { Score }\end{array}$ & $\begin{array}{c}\text { Fatigue } \\
\text { Score }\end{array}$ & $\begin{array}{l}\text { Shortness of } \\
\text { Breath Score }\end{array}$ & $\begin{array}{c}\text { Predicted Survival } \\
\text { Probability at } 3 \text { months } \\
(95 \% \mathrm{Cl})\end{array}$ & $\begin{array}{l}\text { Predicled Survival } \\
\text { Probability at } 6 \text { months } \\
(95 \% \mathrm{Cl})\end{array}$ & $\begin{array}{l}\text { Predicted Survival } \\
\text { Probability at } 1 \text { year } \\
\text { (95\% Cl) }\end{array}$ & $\begin{array}{l}\text { Median } \\
\text { Survival in } \\
\text { weeks } \\
(95 \% \mathrm{Cl})\end{array}$ \\
\hline 801 & $s 50$ & Lung & Bone Only & 4.7 & 0 & 0 & $0.80(0.68-0.94)$ & $0.64(0.47-0.88)$ & $0.43(0.23-0.78)$ & $39(12-80)$ \\
\hline 802 & $\leq 50$ & Lung & Bone Only & $4-7$ & 0 & 1.3 & $0.74(0.60-0.92)$ & $0.56(0.37-0.85)$ & $0.33(0.15-0.73)$ & $31(9-59)$ \\
\hline 803 & $s 50$ & Lung & Bone Only & 4.7 & 0 & 4.7 & $0.68(0.52-0.91)$ & $0.48(0.28-0.82)$ & $0.24(0.09-0.69)$ & $24(7-41)$ \\
\hline 804 & $s 50$ & Lung & Bone Only & 4.7 & 0 & $8-10$ & $0.74(0.58-0.94)$ & $0.55(0.35-0.89)$ & $0.32(0.13-0.79)$ & $30(7-60)$ \\
\hline 805 & $s 50$ & Lung & Bone Only & 4.7 & $1-3$ & 0 & $0.75(0.64-0.88)$ & $0.57(0.43-0.77)$ & $0.34(0.20-0.60)$ & $32(15-52)$ \\
\hline 806 & $\leq 50$ & Lung & Bone Only & $4-7$ & 1.3 & $1-3$ & $0.69(0.57-0.83)$ & $0.48(0.34-0.70)$ & $0.25(0.13-0.50)$ & $24(13-36)$ \\
\hline 807 & $\leq 50$ & Lung & Bone Only & $4-7$ & 1.3 & 4.7 & $0.62(0.48-0.80)$ & $0.39(0.24-0.64)$ & $0.17(0.07-0.43)$ & $19(10-30)$ \\
\hline 808 & $\leq 50$ & Lung & Bone Only & $4-7$ & 1.3 & 8.10 & $0.68(0.55 \cdot 0.86)$ & $0.48(0.31-0.74)$ & $0.24(0.10-0.56)$ & $24(10-38)$ \\
\hline 809 & $\leq 50$ & Lung & Bone Only & 4.7 & 4.7 & 0 & $069(0.57-0.83)$ & $0.48(0.33-0.69)$ & $0.25(0.12-0.49)$ & $24(13-36)$ \\
\hline 810 & $\leq 50$ & Lung & Bone Only & 4.7 & 4.7 & 1.3 & $0.61(049-0.76)$ & $0.38(0.25-0.58)$ & $0.16(0.07-0.36)$ & $19(11-27)$ \\
\hline 811 & $\leq 50$ & Lung & Bone Only & $4-7$ & 4.7 & 4.7 & $0.53(0.40-0.72)$ & $0.29(0.17-0.52)$ & $0.10(0.03-0.29)$ & $14(8-20)$ \\
\hline 812 & $s 50$ & Lung & Bone Only & $4-7$ & 4.7 & $8-10$ & $0.61(0.46-0.81)$ & $0.38(0.22-0.65)$ & $0.15(0.05-0.44)$ & $18(8-28)$ \\
\hline 813 & $\leq 50$ & Lung & Bone Only & $4-7$ & $8-10$ & 0 & $0.66(0.52-0.83)$ & $0.44(0.28-0.70)$ & $0.21(0.09-0.50)$ & $20(10-34)$ \\
\hline 814 & $\leq 50$ & Lung & Bone Only & 4.7 & 8.10 & $1-3$ & $0.58(0.44-0.77)$ & $0.35(0.20-0.59)$ & $0.13(0.05-0.37)$ & $16(8-26)$ \\
\hline 815 & $\$ 50$ & Lung & Bone Only & 4.7 & $8-10$ & $4-7$ & $0.50(0.34-0.72)$ & $0.26(0.12-0.52)$ & $0.07(0.02 \cdot 0.30)$ & $13(6-19)$ \\
\hline 816 & $\leq 50$ & Lung & Bone Only & $4-7$ & $8-10$ & $8-10$ & $0.57(042.0 .79)$ & $0.34(0.18-0.63)$ & $0.12(0.04-0.41)$ & $16(8-26)$ \\
\hline 817 & $\leq 50$ & Lung & Bone Only & $8-10$ & 0 & 0 & $0.67(0.51-0.89)$ & $0.46(0.27-0.80)$ & $0.23(0.08-0.65)$ & $21(7-39)$ \\
\hline 818 & $\leq 50$ & Lurig & Bone Only & $8 \cdot 10$ & 0 & 1.3 & $0.60(0.41-0.87)$ & $0.36(0.18-075)$ & $0.15(0.04-0.58)$ & $17(6-30)$ \\
\hline 819 & $\leq 50$ & Lung & Bone Only & 8.10 & 0 & $4-7$ & $0.52(0.32-0.83)$ & $0.27(0.11-0.69)$ & $0.08(0.01-0.50)$ & $14(4-23)$ \\
\hline 820 & $\leq 50$ & Lung & Bone Only & $8-10$ & 0 & 8.10 & $0.59(0.39-0.89)$ & $0.36(0.16-0.80)$ & $0.14(0.03-0.65)$ & $17(4-30)$ \\
\hline 821 & $\leq 50$ & Lung & Bone Only & 8.10 & $1-3$ & 0 & $0.61(0.46-0.80)$ & $0.38(0.22-0.64)$ & $0.15(0.06-0.43)$ & $18(9-28)$ \\
\hline 822 & $\leq 50$ & Lung & Bone Only & $8-10$ & $1-3$ & $1-3$ & $0.52(0.37-0.74)$ & $0.28(0.15-0.54)$ & $0.09(0.02-0.32)$ & $14(7-20)$ \\
\hline 823 & $\leq 50$ & Lung & Bone Only & $8 \cdot 10$ & 1.3 & 4.7 & $0.44(0.28-0.67)$ & $0.20(0.08-0.46)$ & $0.04(0.01-0.23)$ & $11(6-16)$ \\
\hline 824 & $\leq 50$ & Lung & Bone Only & $8-10$ & $1-3$ & 8.10 & $0.52(0.35-0.77)$ & $0.27(0.13-0.59)$ & $0.08(0.02-0.37)$ & $14(6-20)$ \\
\hline 825 & $\leq 50$ & Lung & Bone Only & 8.10 & 4.7 & 0 & $0.52(0.37-0.72)$ & $0.28(0.15 \cdot 0.53)$ & $0.09(0.02-0.30)$ & $14(7-20)$ \\
\hline 826 & $\leq 50$ & Lung & Bone Only & $8-10$ & 4.7 & 1.3 & $0.43(0.29-0.63)$ & $0.19(0.09-0.40)$ & $0.04(0.01-0.18)$ & $11(6-15)$ \\
\hline 827 & $\leq 50$ & Lung & Bone Only & 8.10 & $4-7$ & 4.7 & $0.33(0.20-0.55)$ & $0.12(0.04-0.31)$ & $0.02(0.00-0.12)$ & $9(5-13)$ \\
\hline 828 & $\leq 50$ & Lung & Bone Only & $8-10$ & 4.7 & $8 \cdot 10$ & $0.42(0.26-0.68)$ & $0.18(0.07-0.47)$ & $0.04(0.01-0.24)$ & $11(5-16)$ \\
\hline 829 & $\leq 50$ & Lung & Bone Only & $8-10$ & $8 \cdot 10$ & 0 & $0.48(0.33 .071)$ & $024(0.11-0.50)$ & $0.06(0.02-0.28)$ & $13(6-19)$ \\
\hline 830 & $\leq 50$ & Lung & Bone Only & $8-10$ & $8-10$ & $1-3$ & $0.39(025.0 .61)$ & $0.16(0.06-0.38)$ & $0.03(0.01-0.16)$ & $10(6-14)$ \\
\hline 831 & $\leq 50$ & Lung & Bone Only & 8.10 & 8.10 & 4.7 & $029(0.17 .053)$ & $0.09(0.03-0.28)$ & $0.01(0.00-0.10)$ & $8(5-12)$ \\
\hline 832 & $\leq 50$ & Lung & Bone Only & $8-10$ & $8 \cdot 10$ & $8 \cdot 10$ & $0.38(0.23-0.63)$ & $015(0.06-0.40)$ & $0.03(0.00-0.18)$ & $10(5-14)$ \\
\hline
\end{tabular}


Appendix 4

\section{Prognostic Index/ Nomogram: Predicted Survival Probability}

\begin{tabular}{|c|c|c|c|c|c|c|c|c|c|c|}
\hline Scenario & $\begin{array}{l}\text { KPS } \\
\text { Score }\end{array}$ & $\begin{array}{c}\text { Primary Cancer } \\
\text { Sile }\end{array}$ & $\begin{array}{c}\text { Site of } \\
\text { Metastases }\end{array}$ & $\begin{array}{l}\text { Appetite } \\
\text { Score }\end{array}$ & $\begin{array}{c}\text { Fatigue } \\
\text { Score }\end{array}$ & $\begin{array}{l}\text { Shortness of } \\
\text { Breath Score }\end{array}$ & $\begin{array}{c}\text { Predicted Survival } \\
\text { Probability at } 3 \text { months } \\
\text { (95\% CI) }\end{array}$ & $\begin{array}{c}\text { Predicted Survival } \\
\text { Probability at } 6 \text { months } \\
\text { (95\% Cl) }\end{array}$ & $\begin{array}{l}\text { Predicted Survival } \\
\text { Probability at } 1 \text { year } \\
\text { (95\% Cl) }\end{array}$ & $\begin{array}{l}\text { Median } \\
\text { Survival in } \\
\text { weeks } \\
\text { (95\% CI) }\end{array}$ \\
\hline 833 & $\leq 50$ & Lung & Others & 0 & 0 & 0 & $0.63(0.47-0.84)$ & $0.40(0.23-0.70)$ & $0.17(0.06-0.51)$ & $19(8-31)$ \\
\hline 834 & $\leq 50$ & Lung & Others & 0 & 0 & 1.3 & $0.54(0.36-0.82)$ & $0.30(0.14-0.67)$ & $0.10(0.02-0.47)$ & $15(6-26)$ \\
\hline 835 & $\leq 50$ & Lung & Others & 0 & 0 & $4-7$ & $0.46(0.27-0.78)$ & $0.22(0.08-0.61)$ & $0.05(0.01-0.39)$ & $12(4-19)$ \\
\hline 836 & $\leq 50$ & Lung & Others & 0 & 0 & $8-10$ & $0.54(0.34-0.85)$ & $0.30(0.12-0.72)$ & $0.10(0.02-0.54)$ & $14(5-26)$ \\
\hline 837 & $\leq 50$ & Lung & Others & 0 & 1.3 & 0 & $0.56(0.43 \cdot 0.72)$ & $0.32(0.19 \cdot 0.53)$ & $0.11(0.04-0.30)$ & $15(9-21)$ \\
\hline 838 & $\leq 50$ & Lung & Others & 0 & 1.3 & 1.3 & $0.47(0.32-0.67)$ & $0.22(0.11-0.45)$ & $0.06(0.01-0.22)$ & $12(7-17)$ \\
\hline 839 & $\leq 50$ & Lung & Others & 0 & $1-3$ & $4-7$ & $0.38(0.23-0.61)$ & $0.15(0.06-0.37)$ & $0.03(0.00-0.16)$ & $10(5-14)$ \\
\hline 840 & $\leq 50$ & Lung & Others & 0 & $1-3$ & $8-10$ & $0.46(0.29-0.71)$ & $0.22(0.09-0.51)$ & $0.05(0.01-0.28)$ & $12(6-19)$ \\
\hline 841 & $s 50$ & Lung & Others & 0 & $4-7$ & 0 & $0.46(0.33-0.65)$ & $0.22(0.11-0.42)$ & $0.06(0.02-0.20)$ & $12(7-16)$ \\
\hline 842 & $\leq 50$ & Lung & Others & 0 & 4.7 & 1.3 & $0.37(0.24-0.56)$ & $0.14(0.06-0.32)$ & $0.02(0.00-0.12)$ & $9(6-13)$ \\
\hline 843 & $\leq 50$ & Lung & Others & 0 & $4-7$ & $4-7$ & $0.27(0.15-0.50)$ & $0.08(0.03-0.25)$ & $0.01(0.00-0.08)$ & $7(4-11)$ \\
\hline 844 & $\leq 50$ & Lung & Others & 0 & $4-7$ & $8-10$ & $0.36(0.20-0.63)$ & $0.13(0.04-0.40)$ & $0.02(0.00-0.18)$ & $9(5-14)$ \\
\hline 845 & $\leq 50$ & Lung & Others & 0 & $8-10$ & 0 & $0.42(0.28-0.64)$ & $0.19(0.08-0.42)$ & $0.04(0.01-0.19)$ & $11(6-16)$ \\
\hline 846 & $\leq 50$ & Lung & Others & 0 & $8-10$ & 1.3 & $0.33(0.19-0.56)$ & $0.11(0.04-0.32)$ & $0.02(0.00-0.12)$ & $8(5.13)$ \\
\hline 847 & $\leq 50$ & Lung & Others & 0 & 8.10 & $4-7$ & $0.24(0.11-0.49)$ & $0.06(0.01-0.25)$ & $0.00(0.00-0.07)$ & $7(3-10)$ \\
\hline 848 & $\leq 50$ & Lung & Others & 0 & $8 \cdot 10$ & $8-10$ & $0.32(0.17-0.59)$ & $0.11(0.03-0.35)$ & $0.01(0.00-0.14)$ & $8(4-13)$ \\
\hline 849 & $\leq 50$ & Lung & Others & $1-3$ & 0 & 0 & $063(0.47 \cdot 0.84)$ & $0.40(0.23 \cdot 0.70)$ & $0.18(0.06-0.51)$ & $19(8-31)$ \\
\hline 850 & $\leq 50$ & Lung & Others & 1.3 & 0 & $1-3$ & $0.55(0.37-0.80)$ & $0.31(0.15 \cdot 0.64)$ & $0.10(0.03-0.43)$ & $15(6-25)$ \\
\hline 851 & $\leq 50$ & Lung & Others & $1-3$ & 0 & $4-7$ & $0.46(0.28-0.76)$ & $0.22(0.08-0.58)$ & $0.05(0.01-0.35)$ & $12(5-19)$ \\
\hline 852 & $\leq 50$ & Lung & Others & $1-3$ & 0 & $8-10$ & $0.54(0.35-0.83)$ & $0.30(0.13-0.69)$ & $0.10(0.02-0.50)$ & $14(5-26)$ \\
\hline 853 & $\leq 50$ & Lung & Others & 1.3 & $1-3$ & 0 & $0.56(0.43-0.72)$ & $032(019-0.53)$ & $0.11(0.04-0.29)$ & $15(9-21)$ \\
\hline 854 & $\leq 50$ & Lung & Others & 1.3 & 1.3 & 1.3 & $0.47(0.34-0.64)$ & $0.23(0.12-0.42)$ & $0.06(0.02-0.19)$ & $12(7-16)$ \\
\hline 855 & $\leq 50$ & Lung & Others & $1-3$ & 1.3 & $4-7$ & $0.38(0.25-0.58)$ & $0.15(0.07-0.34)$ & $0.03(0.01-0.13)$ & $10(6-13)$ \\
\hline 856 & $\leq 50$ & Lung & Others & $1-3$ & 1.3 & $8-10$ & $0.46(0.31-0.69)$ & $0.22(0.10-0.47)$ & $0.05(0.01-0.24)$ & $12(6-18)$ \\
\hline 857 & $\leq 50$ & Lung & Others & $1 \cdot 3$ & $4 \cdot 7$ & 0 & $0.46(0.34-0.64)$ & $0.22(0.12-0.41)$ & $0.06(0.02-0.18)$ & $12(7-16)$ \\
\hline 858 & $s 50$ & Lung & Others & 1.3 & $4-7$ & $1-3$ & $0.37(026-0.52)$ & $0.14(0.07-0.27)$ & $0.02(0.01-0.09)$ & $9(6-13)$ \\
\hline 859 & $\leq 50$ & Lung & Others & $1 \cdot 3$ & $4-7$ & $4-7$ & $0.28(0.17-0.45)$ & $0.08(0.03-0.21)$ & $0.01(0.00-0.05)$ & $7(5-10)$ \\
\hline 860 & $\mathbf{s 5 0}$ & Lung & Others & $1-3$ & $4-7$ & $8-10$ & $0.36(0.22-0.59)$ & $0.13(0.05-0.35)$ & $0.02(0.00-0.14)$ & $9(5-13)$ \\
\hline 861 & $\leq 50$ & Lung & Others & 1.3 & $8 \cdot 10$ & 0 & $0.42(0.28 .0 .65)$ & $0.19(0.08-0.42)$ & $0.04(0.01-0.20)$ & $11(6-16)$ \\
\hline 862 & $\leq 50$ & Lung & Others & 1.3 & $8-10$ & $1-3$ & $0.33(0.20-0.54)$ & $0.11(0.04-0.29)$ & $0.02(0.00-0.10)$ & $8(5-12)$ \\
\hline 863 & $\leq 50$ & Lung & Others & $1-3$ & $8-10$ & $4-7$ & $0.24(0.12-0.46)$ & $0.06(0.02-0.22)$ & $0.00(0.00-0.06)$ & $7(4-10)$ \\
\hline 864 & $\leq 50$ & Lung & Others & 1.3 & $8-10$ & $8-10$ & $0.32(0.18-0.57)$ & $0.11(0.04-0.33)$ & $0.01(0.00-0.12)$ & $8(5-13)$ \\
\hline
\end{tabular}


Appendix 4

Prognostic Index/ Nomogram: Predicted Survival Probability

\begin{tabular}{|c|c|c|c|c|c|c|c|c|c|c|}
\hline Scenario & $\begin{array}{l}\text { KPS } \\
\text { Score }\end{array}$ & $\begin{array}{c}\text { Primary Cancer } \\
\text { Sile }\end{array}$ & $\begin{array}{c}\text { Site of } \\
\text { Metastases }\end{array}$ & $\begin{array}{l}\text { Appelite } \\
\text { Score }\end{array}$ & $\begin{array}{l}\text { Fatigue } \\
\text { Score }\end{array}$ & $\begin{array}{l}\text { Shortness of } \\
\text { Breath Score }\end{array}$ & $\begin{array}{l}\text { Predicted Survival } \\
\text { Probability at } 3 \text { months } \\
(95 \% \mathrm{Cl})\end{array}$ & $\begin{array}{c}\text { Predicted Survival } \\
\text { Probability at } 6 \text { months } \\
\text { (95\% CI) }\end{array}$ & $\begin{array}{c}\text { Predicted Survival } \\
\text { Probability at } 1 \text { year } \\
(95 \% \text { CI) }\end{array}$ & $\begin{array}{l}\text { Median } \\
\text { Survival in } \\
\text { weeks } \\
(95 \% \mathrm{Cl})\end{array}$ \\
\hline 865 & $\leq 50$ & Lung & Others & $4-7$ & 0 & 0 & $0.63(0.46-084)$ & $040(0.22-0.71)$ & $0.17(0.06-0.53)$ & $19(7-32)$ \\
\hline 866 & $\leq 50$ & Lung & Others & 4.7 & 0 & 1.3 & $0.54(0.36 \cdot 0.61)$ & $0.30(0.14 \cdot 0.66)$ & $0.10(0.02-0.45)$ & $15(6-26)$ \\
\hline 867 & $\leq 50$ & Lung & Olhers & $4-7$ & 0 & $4-7$ & $0.46(0.27-0.77)$ & $0.22(0.08-0.60)$ & $0.05(0.01-0.38)$ & $12(4-19)$ \\
\hline 868 & $\leq 50$ & Lung & Others & $4-7$ & 0 & 8.10 & $0.54(0.34-0.84)$ & $0.30(0.12-0.71)$ & $0.10(0.02-0.53)$ & $14(5-26)$ \\
\hline 869 & $\leq 50$ & Lung & Olhers & 4.7 & 1.3 & 0 & $0.55(0.43-0.72)$ & $0.32(0.19 \cdot 0.52)$ & $0.11(0.04-0.29)$ & $15(9-21)$ \\
\hline 870 & $\leq 50$ & Lung & Others & $4-7$ & 1.3 & 1.3 & $0.46(0.34-0.64)$ & $0.22(0.12-0.42)$ & $0.06(0.02-0.19)$ & $12(7-17)$ \\
\hline 871 & $\leq 50$ & Lung & Others & $4-7$ & $1-3$ & $4-7$ & $0.37(0.24-0.58)$ & $0.15(0.06-0.34)$ & $0.03(0.00-0.13)$ & $10(6-14)$ \\
\hline 872 & $\leq 50$ & Lung & Others & 4.7 & $1-3$ & 8.10 & $0.46(0.30-0.69)$ & $0.22(0.10-0.47)$ & $0.05(0.01-0.24)$ & $12(6-17)$ \\
\hline 873 & $\leq 50$ & Lung & Others & $4-7$ & $4-7$ & 0 & $0.46(0.34-0.63)$ & $0.22(0.12-0.40)$ & $0.05(0.02-0.18)$ & $12(7-16)$ \\
\hline 874 & $\leq 50$ & Lung & Others & $4-7$ & $4-7$ & $1-3$ & $0.36(0.26-0.52)$ & $0.14(0.07-0.27)$ & $0.02(0.01-0.09)$ & $9(6-13)$ \\
\hline 875 & $\leq 50$ & Lung & Oiners & 4.7 & $4-7$ & $4-7$ & $0.27(0.17-0.45)$ & $0.08(0.03-0.20)$ & $0.01(0.00-0.05)$ & $7(5-10)$ \\
\hline 876 & $\leq 50$ & Lung & Others & $4-7$ & $4-7$ & 8.10 & $0.36(0.22-0.58)$ & $0.13(0.05-0.35)$ & $0.02(0.00-0.14)$ & $9(5-13)$ \\
\hline 877 & $\leq 50$ & Lung & Others & $4-7$ & $8-10$ & 0 & $0.42(0.28-0.63)$ & $0.18(0.08-0.40)$ & $0.04(0.01-0.18)$ & $11(6-15)$ \\
\hline 878 & $\leq 50$ & Lung & Others & $4-7$ & $8-10$ & $1-3$ & $0.33(0.20-0.52)$ & $0.11(0.04-0.27)$ & $0.01(0.00-0.09)$ & $8(5-12)$ \\
\hline 879 & $\leq 50$ & Lung & Others & $4-7$ & $8 \cdot 10$ & $4-7$ & $0.24(0.13 .0 .44)$ & $0.06(0.02-0.20)$ & $0.00(0.00-0.05)$ & $7(4-9)$ \\
\hline 880 & $s 50$ & Lung & Others & $4-7$ & 8.10 & 8.10 & $0.32(0.18-0.55)$ & $0.11(0.04-0.30)$ & $0.01(0.00-0.11)$ & $8(5-12)$ \\
\hline 881 & $\leq 50$ & Lung & Others & $8-10$ & 0 & 0 & $0.44(0.26-0.75)$ & $0.20(0.07-0.57)$ & $0.05(0.01-0.35)$ & $11(5-19)$ \\
\hline 882 & $\leq 50$ & Lung & Others & $8-10$ & 0 & 1.3 & $0.34(0.17 \cdot 0.70)$ & $0.12(0.03-0.50)$ & $0.02(0.00-0.28)$ & $9(3-14)$ \\
\hline 883 & $\leq 50$ & Lung & Others & $8-10$ & 0 & $4-7$ & $0.25(0.10-0.63)$ & $0.07(0.01-0.41)$ & $0.01(0.00-0.19)$ & $7(3-11)$ \\
\hline 884 & $\leq 50$ & Lung & Others & $8-10$ & 0 & $8-10$ & $0.34(0.15-0.74)$ & $0.12(0.03 .056)$ & $0.02(0.00-0.34)$ & $9(3.14)$ \\
\hline 885 & $\leq 50$ & Lung & Others & $8-10$ & $1-3$ & 0 & $0.36(0.22-0.59)$ & $013(0.05-0.35)$ & $0.02(0.00-0.14)$ & $9(5-13)$ \\
\hline 886 & $\leq 50$ & Lung & Others & $8-10$ & $1-3$ & $1-3$ & $0.26(0.14-0.50)$ & $0.07(0.02-0.25)$ & $0.01(0.00-0.08)$ & $7(4-11)$ \\
\hline 887 & $\leq 50$ & Lung & Others & 8.10 & $1-3$ & $4-7$ & $0.18(0.08-0.40)$ & $0.03(0.01-0.17)$ & $0.00(0.00-0.04)$ & $6(3-9)$ \\
\hline 888 & $\leq 50$ & Lung & Others & $8-10$ & 1.3 & 8.10 & $0.25(0.12-0.54)$ & $0.07(0.02-0.29)$ & $0.01(0.00-0.10)$ & $7(3-11)$ \\
\hline 889 & $\leq 50$ & Lung & Others & $8-10$ & 4.7 & 0 & $0.26(0.14-0.47)$ & $0.07(0.02-0.23)$ & $0.01(0.00 \cdot 0.06)$ & $7(4-10)$ \\
\hline 890 & $\leq 50$ & Lung & Others & $8 \cdot 10$ & 4.7 & 1.3 & $0.17(0.08-0.35)$ & $0.03(0.01-0.13)$ & $0.00(0.00-0.02)$ & $6(3-8)$ \\
\hline 891 & $\leq 50$ & Lung & Olhers & $8-10$ & 4.7 & $4-7$ & $0.10(004-0.26)$ & $0.01(0.00-0.07)$ & $0.00(0.00-0.01)$ & $5(3-6)$ \\
\hline 892 & $\leq 50$ & Lung & Others & $8-10$ & $4-7$ & 8.10 & $0.16(0.07-0.41)$ & $0.03(0.00-0.17)$ & $0.00(0.00-0.04)$ & $6(3-8)$ \\
\hline 893 & $\leq 50$ & Lung & Others & $8-10$ & $8-10$ & 0 & $022(0.11-0.44)$ & $0.05(0.01-0.20)$ & $0.00(0.00-0.05)$ & $6(4-9)$ \\
\hline 894 & $s 50$ & Lung & Others & $8-10$ & $8 \cdot 10$ & $1-3$ & $014(006-0.31)$ & $0.02(0.00-0.10)$ & $0.00(0.00-0.01)$ & $6(3-7)$ \\
\hline 895 & $\leq 50$ & Lung & Others & $8-10$ & $8 \cdot 10$ & $4-7$ & $0.08(0.03 \cdot 0.22)$ & $0.01(0.00-0.05)$ & $0.00(0.00-0.00)$ & $4(3.6)$ \\
\hline 896 & $\leq 50$ & Lung & Others & $8-10$ & $8-10$ & $8 \cdot 10$ & $013(0.05-0.33)$ & $002(0.00-0.11)$ & $0.00(0.00-0.02)$ & $5(3-7)$ \\
\hline
\end{tabular}




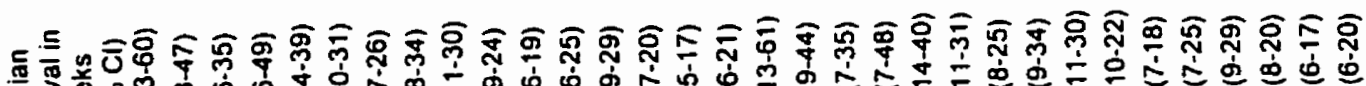

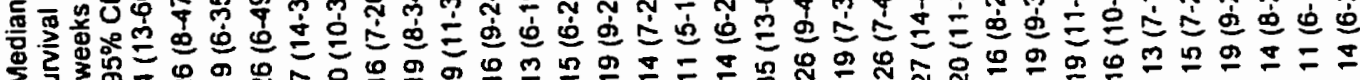

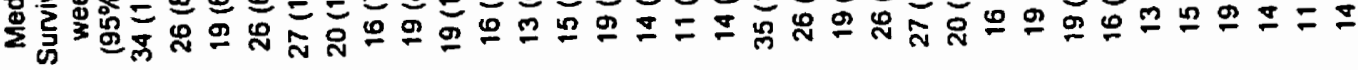

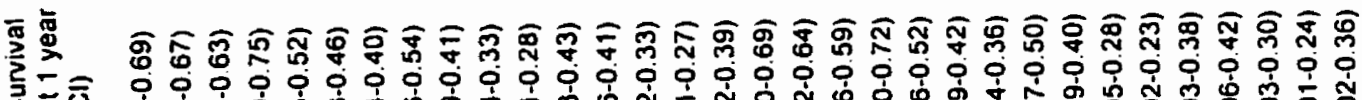

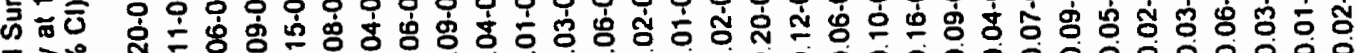

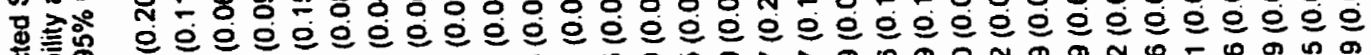
응

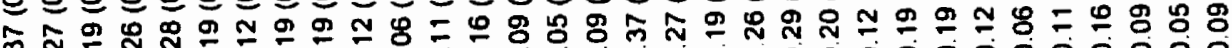
○ 0 0 00000000000000000000000000000

要

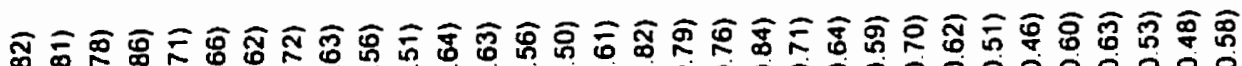
ถึำ

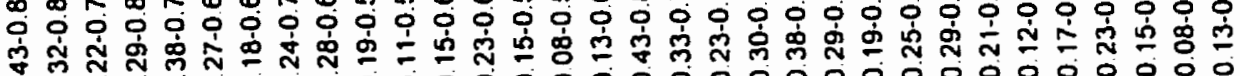

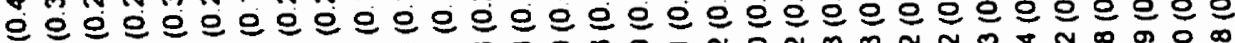

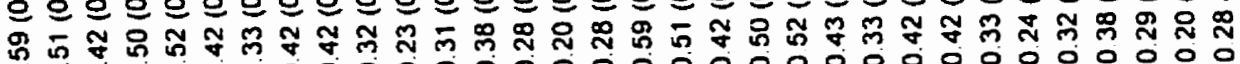
这

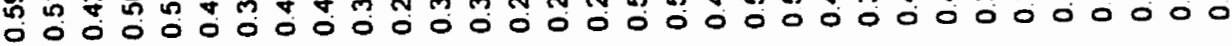

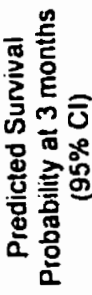

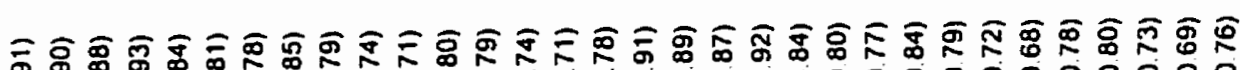

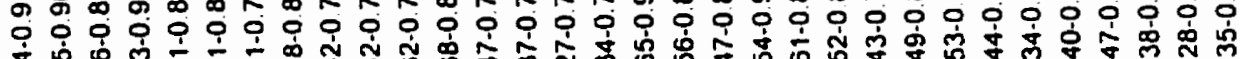

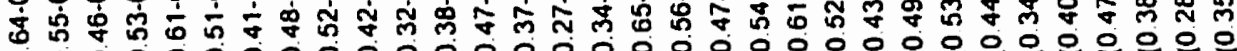

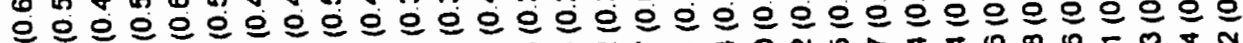

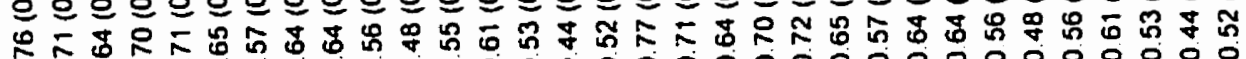

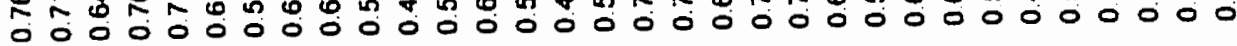

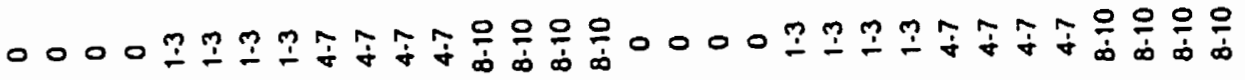
产号号

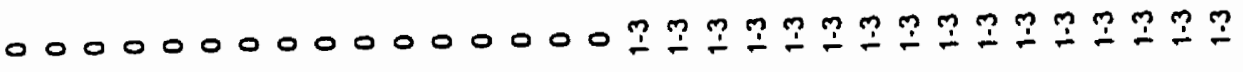

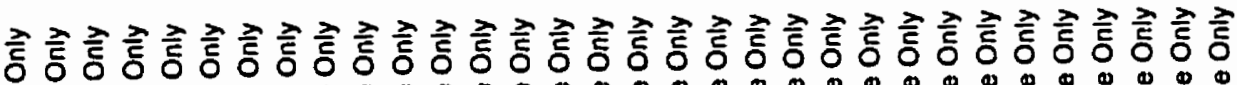

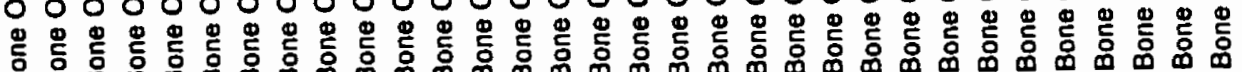

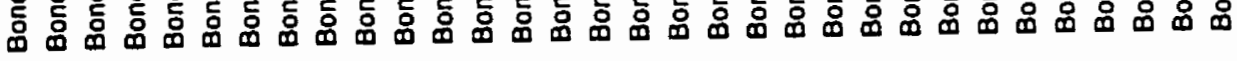




\section{Appendix 4}

Prognostic Index/ Nomogram: Predicted Survival Probability

\begin{tabular}{|c|c|c|c|c|c|c|c|c|c|c|}
\hline Scenario & $\begin{array}{l}\text { KPS } \\
\text { Score }\end{array}$ & $\begin{array}{l}\text { Primary Cancer } \\
\text { Site }\end{array}$ & $\begin{array}{c}\text { Site of } \\
\text { Metastases }\end{array}$ & $\begin{array}{l}\text { Appetite } \\
\text { Score }\end{array}$ & $\begin{array}{l}\text { Fatigue } \\
\text { Score }\end{array}$ & $\begin{array}{l}\text { Shortness of } \\
\text { Breath Score }\end{array}$ & $\begin{array}{c}\text { Predicted Survival } \\
\text { Probability at } 3 \text { months } \\
\text { (95\% Cl) }\end{array}$ & $\begin{array}{c}\text { Predicted Survival } \\
\text { Probability at } 6 \text { months } \\
\text { (95\% Cl) }\end{array}$ & $\begin{array}{c}\text { Predicted Survival } \\
\text { Probability at } 1 \text { year } \\
(95 \% \mathrm{Cl})\end{array}$ & $\begin{array}{l}\text { Median } \\
\text { Survival in } \\
\text { weeks } \\
(95 \% \mathrm{Cl})\end{array}$ \\
\hline 929 & 550 & Others & Bone Only & $4-7$ & 0 & 0 & $0.76(0.64-0.91)$ & $0.59(0.42-0.83)$ & $0.36(0.19-0.69)$ & $34(13-61)$ \\
\hline 930 & $\leq 50$ & Others & Bone Only & $4-7$ & 0 & $1-3$ & $0.70(0.56-0.89)$ & $0.50(0.32-0.80)$ & $0.27(0.11-0.64)$ & $26(9-45)$ \\
\hline 931 & $\leq 50$ & Others & Bone Only & $4-7$ & 0 & $4-7$ & $0.64(0.46-0.88)$ & $0.42(0.22-0.77)$ & $0.19(0.06-0.60)$ & $19(6-35)$ \\
\hline 932 & $s 50$ & Others & Bone Only & $4 \cdot 7$ & 0 & $8 \cdot 10$ & $0.70(0.53-0.92)$ & $0.50(0.29-0.85)$ & $0.26(0.09-0.73)$ & $26(6.48)$ \\
\hline 933 & $\leq 50$ & Olhers & Bone Only & $4-7$ & 1.3 & 0 & $0.71(0.61-0.84)$ & $0.52(0.38-0.70)$ & $0.28(0.16-0.50)$ & $27(14-39)$ \\
\hline 934 & $\leq 50$ & Others & Bone Only & $4-7$ & $1 \cdot 3$ & $1 \cdot 3$ & $0.64(0.52-0.79)$ & $0.42(0.29-0.63)$ & $0.19(0.09-0.41)$ & $20(11-30)$ \\
\hline 935 & $\leq 50$ & Others & Bone Only & $4-7$ & $1-3$ & 4.7 & $0.57(0.43-0.76)$ & $0.33(0.19-0.58)$ & $0.12(0.04-0.35)$ & $16(8-25)$ \\
\hline 936 & $\leq 50$ & Olhers & Bone Only & 4.7 & 1.3 & $8-10$ & $0.64(0.49-0.83)$ & $0.42(0.25-0.69)$ & $0.19(0.07-0.49)$ & $19(9-33)$ \\
\hline 937 & $\leq 50$ & Others & Bone Only & $4-7$ & $4-7$ & 0 & $0.64(0.53-0.77)$ & $0.42(0.29-0.60)$ & $0.19(0.09-0.38)$ & $19(12-29)$ \\
\hline 938 & $\leq 50$ & Others & Bone Only & 4.7 & $4-7$ & 1.3 & $0.56(0.45 .0 .70)$ & $0.32(0.21-0.50)$ & $0.11(0.05-0.26)$ & $15(10-20)$ \\
\hline 939 & $\leq 50$ & Others & Bone Only & $4-7$ & $4-7$ & 4.7 & $047(0.34-0.67)$ & $0.23(0.12-0.45)$ & $0.06(0.02-0.22)$ & $13(7-18)$ \\
\hline 940 & $s 50$ & Others & Bone Only & $4-7$ & 4.7 & $8-10$ & $0.55(0.40-0.77)$ & $0.31(0.17-0.59)$ & $0.11(0.03 \cdot 0.37)$ & $15(7-23)$ \\
\hline 941 & $\leq 50$ & Others & Bone Only & $4-7$ & $8-10$ & 0 & $061(0.48-0.78)$ & $0.38(0.24-0.60)$ & $0.16(0.06-0.38)$ & $18(10-27)$ \\
\hline 942 & $\leq 50$ & Others & Bone Only & $4-7$ & $8-10$ & $1-3$ & $0.52(0.39-0.71)$ & $0.28(0.16-0.50)$ & $0.09(0.03-0.27)$ & $14(8-20)$ \\
\hline 943 & $\leq 50$ & Others & Bone Only & $4-7$ & $8-10$ & $4-7$ & $0.44(0.29-0.66)$ & $0.20(0.09 \cdot 0.44)$ & $0.05(0.01 \cdot 0.21)$ & $11(6-16)$ \\
\hline 944 & $\leq 50$ & Others & Bone Only & 4.7 & $8 \cdot 10$ & $8-10$ & $0.52(0.36-0.74)$ & $0.28(0.14-0.55)$ & $0.08(0.02-0.33)$ & $14(7-20)$ \\
\hline 945 & $\leq 50$ & Others & Bone Only & $8-10$ & 0 & 0 & $0.62(0.46 .0 .85)$ & $0.40(0.22-0.72)$ & $0.17(0.05-0.54)$ & $19(7-32)$ \\
\hline 946 & $\leq 50$ & Others & Bone Only & $8-10$ & 0 & $1-3$ & $054(0.36-0.82)$ & $0.30(0.13 \cdot 0.68)$ & $0.10(0.02-0.48)$ & $14(6-25)$ \\
\hline 947 & $\leq 50$ & Others & Bone Only & $8 \cdot 10$ & 0 & $4 \cdot 7$ & $0.46(0.26 \cdot 0.79)$ & $0.21(0.07-0.62)$ & $0.05(0.01-0.41)$ & $12(4-19)$ \\
\hline 948 & $\leq 50$ & Others & Bone Only & 8.10 & 0 & $8-10$ & $0.53(0.33-0.86)$ & $0.29(0.12 \cdot 0.74)$ & $0.10(0.02-0.58)$ & $14(4-26)$ \\
\hline 949 & $\leq 50$ & Others & Bone Only & $8 \cdot 10$ & $1-3$ & 0 & $055(0.41-0.74)$ & $0.31(0.18-0.56)$ & $0.11(0.04-0.33)$ & $15(8-22)$ \\
\hline 950 & $\leq 50$ & Others & Bone Only & $8-10$ & 1.3 & $1-3$ & $0.46(0.31 .0 .68)$ & $0.22(0.10-0.47)$ & $0.06(0.01-0.24)$ & $12(6-18)$ \\
\hline 951 & $\leq 50$ & Others & Bone Only & $8-10$ & $1-3$ & $4-7$ & $0.37(0.22-0.62)$ & $0.14(0.05-0.39)$ & $0.02(0.00-0.18)$ & $9(5-14)$ \\
\hline 952 & $\leq 50$ & Others & Bone Only & $8-10$ & 1.3 & $8-10$ & $046(0.28 \cdot 0.73)$ & $0.21(0.09-0.54)$ & $0.05(0.01-0.31)$ & $12(5-19)$ \\
\hline 953 & $s 50$ & Others & Bone Only & $8-10$ & $4-7$ & 0 & $0.46(0.32-0.65)$ & $0.22(0.11-0.43)$ & $0.05(0.01-0.21)$ & $12(7-17)$ \\
\hline 954 & $\leq 50$ & Others & Bone Only & $8-10$ & $4-7$ & 1.3 & $0.36(0.24-0.56)$ & $0.14(0.06 \cdot 0.32)$ & $0.02(0.00-0.12)$ & $9(6.13)$ \\
\hline 955 & $\leq 50$ & Others & Bone Only & $8-10$ & $4 \cdot 7$ & 4.7 & $027(0 \quad 15 \cdot 0.49)$ & $0.08(0.02-0.25)$ & $0.01(0.00-0.08)$ & $7(4-11)$ \\
\hline 956 & $\leq 50$ & Others & Bone Only & $8-10$ & 4.7 & $8-10$ & $035(020-0.63)$ & $0.13(0.04-0.41)$ & $0.02(0.00-0.19)$ & $9(5-14)$ \\
\hline 957 & $\$ 50$ & Others & Bone Only & $8-10$ & $8 \cdot 10$ & 0 & $0.42(0.28-0.63)$ & $0.18(0.08-0.40)$ & $0.04(0.01-0.18)$ & $11(6-15)$ \\
\hline 958 & $\leq 50$ & Others & Bone Only & $8-10$ & $8-10$ & $1-3$ & $0.32(0.20 \cdot 0.53)$ & $0.11(0.04-0.29)$ & $0.01(0.00-0.10)$ & $8(5-12)$ \\
\hline 959 & $s 50$ & Others & Bone Only & $8-10$ & $8-10$ & $4-7$ & $0.23(0.12-0.46)$ & $0.06(0.02-0.22)$ & $0.00(0.00-0.06)$ & $7(4-10)$ \\
\hline 960 & $\leq 50$ & Others & Bone Only & $8-10$ & $8-10$ & $8-10$ & $032(0.17-0.57)$ & $0.10(0.03-0.33)$ & $0.01(0.00-0.13)$ & $8(4-13)$ \\
\hline
\end{tabular}


Appendix 4

Prognostic Index/ Nomogram: Predicted Survival Probability

\begin{tabular}{|c|c|c|c|c|c|c|c|c|c|c|}
\hline Scenario & $\begin{array}{l}\text { KPS } \\
\text { Score }\end{array}$ & $\begin{array}{l}\text { Primary Cancer } \\
\text { Site }\end{array}$ & $\begin{array}{c}\text { Site of } \\
\text { Melastases }\end{array}$ & $\begin{array}{l}\text { Appetite } \\
\text { Score }\end{array}$ & $\begin{array}{l}\text { Fatigue } \\
\text { Score }\end{array}$ & $\begin{array}{l}\text { Shortness of } \\
\text { Breath Score }\end{array}$ & $\begin{array}{c}\text { Predicted Survival } \\
\text { Probability at } 3 \text { months } \\
\text { (95\% Cl) }\end{array}$ & $\begin{array}{c}\text { Predicled Survival } \\
\text { Probability at } 6 \text { months } \\
(95 \% \mathrm{CI})\end{array}$ & $\begin{array}{c}\text { Predicted Survival } \\
\text { Probability at } 1 \text { year } \\
(95 \% \mathrm{Cl})\end{array}$ & $\begin{array}{l}\text { Median } \\
\text { Survival in } \\
\text { weeks } \\
(95 \% \mathrm{Cl})\end{array}$ \\
\hline 961 & $s 50$ & Others & Others & 0 & 0 & 0 & $0.57(0.41-0.79)$ & $0.34(0.18-0.63)$ & $0.13(0.04-0.42)$ & $16(7-26)$ \\
\hline 962 & $\leq 50$ & Others & Others & 0 & 0 & $1-3$ & $0.49(0.30-0.78)$ & $0.24(0.10-0.61)$ & $0.07(0.01-0.39)$ & $13(5-20)$ \\
\hline 963 & $\leq 50$ & Others & Others & 0 & 0 & 4.7 & $0.40(0.21-0.75)$ & $0.16(0.05-0.56)$ & $0.03(0.00-0.34)$ & $10(3-16)$ \\
\hline 964 & $s 50$ & Others & Others & 0 & 0 & $8-10$ & $0.48(0.28-0.83)$ & $0.24(0.08-0.69)$ & $0.06(0.01-0.50)$ & $13(3-20)$ \\
\hline 965 & $s 50$ & Others & Others & 0 & $1-3$ & 0 & $0.50(0.37-0.68)$ & $0.26(0.14-0.46)$ & $0.07(0.02-0.23)$ & $13(8-19)$ \\
\hline 966 & $\leq 50$ & Others & Others & 0 & $1-3$ & $1-3$ & $0.40(0.26-0.63)$ & $0.17(0.07 \cdot 0.41)$ & $0.03(0.01-0.18)$ & $10(6-15)$ \\
\hline 967 & $\leq 50$ & Others & Others & 0 & 1.3 & 4.7 & $0.31(0.17-0.58)$ & $0.10(0.03-0.34)$ & $0.01(0.00-0.13)$ & $8(4-13)$ \\
\hline 968 & $\leq 50$ & Others & Others & 0 & $1-3$ & $8-10$ & $0.40(0.23-0.69)$ & $0.16(0.06-0.48)$ & $0.03(0.00-0.25)$ & $10(5-16)$ \\
\hline 969 & $\leq 50$ & Others & Others & 0 & $4-7$ & 0 & $0.40(0.27-0.59)$ & $0.17(0.08-0.35)$ & $0.03(0.01-0.14)$ & $10(6-14)$ \\
\hline 970 & $\leq 50$ & Others & Others & 0 & $4-7$ & 1.3 & $0.30(0.18-0.52)$ & $0.10(0.03 \cdot 0.28)$ & $0.01(0.00-0.09)$ & $8(5-11)$ \\
\hline 971 & $\leq 50$ & Others & Others & 0 & $4-7$ & 4.7 & $0.22(0.10-0.47)$ & $0.05(0.01-0.22)$ & $0.00(0.00-0.06)$ & $6(3-9)$ \\
\hline 972 & $\leq 50$ & Olhers & Others & 0 & $4-7$ & $8-10$ & $0.29(0.14-0.60)$ & $0.09(0.02-0.37)$ & $0.01(0.00-0.15)$ & $8(3-13)$ \\
\hline 973 & $\leq 50$ & Olhers & Others & 0 & $8-10$ & 0 & $0.36(0.22-0.58)$ & $0.14(0.05-0.34)$ & $0.02(0.00-0.13)$ & $9(6-13)$ \\
\hline 974 & $\leq 50$ & Others & Others & 0 & $8 \cdot 10$ & 1.3 & $0.26(0.14-0.51)$ & $0.07(0.02-0.27)$ & $0.01(0.00-0.08)$ & $7(4-11)$ \\
\hline 975 & $\leq 50$ & Others & Others & 0 & $8 \cdot 10$ & 4.7 & $0.18(0.07-0.45)$ & $0.04(0.01-0.21)$ & $0.00(0.00 \cdot 0.05)$ & $6(3-9)$ \\
\hline 976 & $\leq 50$ & Olhers & Others & 0 & 8.10 & $8-10$ & $0.26(0.12-0.56)$ & $0.07(0.02-0.32)$ & $0.01(0.00-0.11)$ & $7(3-11)$ \\
\hline 977 & $\leq 50$ & Others & Others & 1.3 & 0 & 0 & $058(042-0.79)$ & $0.34(0.18-0.63)$ & $0.13(0.04-0.41)$ & $16(7-26)$ \\
\hline 978 & $\mathbf{s 5 0}$ & Others & Others & 1.3 & 0 & $1-3$ & $0.49(0.31-0.76)$ & $0.25(0.10-0.58)$ & $0.07(0.01-0.35)$ & $13(6-19)$ \\
\hline 979 & $\leq 50$ & Others & Others & $1-3$ & 0 & 4.7 & $0.40(022-0.72)$ & $0.16(0.05-0.53)$ & $0.03(0.00-0.29)$ & $10(4-16)$ \\
\hline 980 & $\leq 50$ & Others & Others & 1.3 & 0 & $8-10$ & $0.48(028.0 .81)$ & $0.24(0.09-0.66)$ & $0.06(0.01-0.45)$ & $13(4-20)$ \\
\hline 981 & $\leq 50$ & Olhers & Others & 1.3 & $1-3$ & 0 & $0.50(0.37-0.68)$ & $0.26(0.14-0.46)$ & $0.07(0.02-0.23)$ & $13(8 \cdot 19)$ \\
\hline 982 & $\leq 50$ & Others & Others & 1.3 & 1.3 & 1.3 & $0.41(0.27 \cdot 0.60)$ & $0.17(0.08-0.37)$ & $0.03(0.01-0.15)$ & $10(6-14)$ \\
\hline 983 & $\$ 50$ & Others & Others & 1.3 & $1-3$ & $4-7$ & $031(0.18-0.55)$ & $0.10(0.04-0.30)$ & $0.01(0.00-0.10)$ & $8(5-12)$ \\
\hline 984 & $\leq 50$ & Others & Others & $1-3$ & 1.3 & $8-10$ & $0.40(0.24-0.66)$ & $0.16(0.06-0.44)$ & $0.03(0.00-0.21)$ & $10(5-16)$ \\
\hline 985 & $\leq 50$ & Others & Others & 1.3 & 4.7 & 0 & $0.40(0.28-0.58)$ & $0.17(0.08-0.34)$ & $0.03(0.01-0.13)$ & $10(6-14)$ \\
\hline 986 & $\leq 50$ & Others & Olners & $1-3$ & $4-7$ & $1-3$ & $0.30(0.20-0.47)$ & $0.10(0.04-0.23)$ & $0.01(0.00-0.06)$ & $8(6-11)$ \\
\hline 987 & $\leq 50$ & Others & Others & 1.3 & $4-7$ & 4.7 & $022(0.11-0.42)$ & $0.05(0.01-0.18)$ & $0.00(0.00-0.04)$ & $6(4-9)$ \\
\hline 988 & $\leq 50$ & Others & Others & 1.3 & $4-7$ & $8-10$ & $0.30(0.16-0.56)$ & $0.09(0.03-0.32)$ & $0.01(0.00-0.11)$ & $8(4-12)$ \\
\hline 989 & $\leq 50$ & Others & Others & $1-3$ & $8-10$ & 0 & $036(022-058)$ & $0.14(0.05-0.35)$ & $0.02(0.00-0.13)$ & $9(5-13)$ \\
\hline 990 & $\leq 50$ & Others & Others & $1-3$ & $8 \cdot 10$ & 1.3 & $0.27(0.15-0.48)$ & $0.08(0.02-0.24)$ & $0.01(0.00-0.07)$ & $7(4-11)$ \\
\hline 991 & $\leq 50$ & Others & Others & 1.3 & $8-10$ & 4.7 & $0.18(0.08-0.42)$ & $0.04(0.01-0.18)$ & $0.00(0.00-0.04)$ & $6(3-9)$ \\
\hline 992 & $s 50$ & Others & Others & 1.3 & $8-10$ & $8-10$ & $0.26(0.13 .0 .53)$ & $0.07(0.02-0.28)$ & $0.01(0.00-0.09)$ & $7(4-11)$ \\
\hline
\end{tabular}


Appendix 4

Prognostic Index/ Nomogram: Predicted Survival Probability

\begin{tabular}{|c|c|c|c|c|c|c|c|c|c|c|}
\hline Scenario & $\begin{array}{l}\text { KPS } \\
\text { Score }\end{array}$ & $\begin{array}{c}\text { Primary Cancer } \\
\text { Site }\end{array}$ & $\begin{array}{l}\text { Site of } \\
\text { Metastases }\end{array}$ & $\begin{array}{l}\text { Appetile } \\
\text { Score }\end{array}$ & $\begin{array}{c}\text { Fatigue } \\
\text { Score }\end{array}$ & $\begin{array}{l}\text { Shortness of } \\
\text { Breath Score }\end{array}$ & $\begin{array}{c}\text { Predicted Survival } \\
\text { Probability at } 3 \text { months } \\
(95 \% \mathrm{Cl})\end{array}$ & $\begin{array}{c}\text { Predicted Survival } \\
\text { Probability at } 6 \text { months } \\
(95 \% \mathrm{Cl})\end{array}$ & $\begin{array}{l}\text { Predicted Survival } \\
\text { Probability at } 1 \text { year } \\
(95 \% \mathrm{Cl})\end{array}$ & $\begin{array}{l}\text { Median Survival } \\
\text { in weeks } \\
(95 \% \mathrm{CI})\end{array}$ \\
\hline 993 & $\leq 50$ & Others & Others & $4-7$ & 0 & 0 & $0.57(0.41-0.79)$ & $0.34(0.18-0.63)$ & $0.12(0.04-0.42)$ & $16(7-26)$ \\
\hline 994 & $\leq 50$ & Others & Others & 4.7 & 0 & $1-3$ & $0.48(0.31-0.76)$ & $0.24(0.10-0.59)$ & $0.07(0.01-0.36)$ & $13(6-20)$ \\
\hline 995 & $\leq 50$ & Others & Others & 4.7 & 0 & $4-7$ & $0.39(0.21-0.73)$ & $0.16(0.05 \cdot 0.53)$ & $0.03(0.00-0.30)$ & $10(4-16)$ \\
\hline 996 & $s 50$ & Others & Olhers & $4-7$ & 0 & $8 \cdot 10$ & $0.48(0.28 \cdot 0.81)$ & $0.23(0.08-0.66)$ & $0.06(0.01-0.45)$ & $13(4-20)$ \\
\hline 997 & $\leq 50$ & Others & Others & $4-7$ & $1-3$ & 0 & $0.50(0.37-0.66)$ & $0.25(0.15-0.44)$ & $0.07(0.03-0.21)$ & $13(8-19)$ \\
\hline 998 & $s 50$ & Others & Others & 4.7 & 1.3 & $1-3$ & $040(0.28-0.59)$ & $0.17(0.08-0.35)$ & $0.03(0.01-0.14)$ & $10(6-14)$ \\
\hline 999 & $\mathbf{s 5 0}$ & Others & Others & $4-7$ & $1-3$ & $4-7$ & $0.31(0.18-0.53)$ & $0.10(0.04-0.29)$ & $0.01(0.00-0.10)$ & $8(5-12)$ \\
\hline 1000 & $\leq 50$ & Others & Others & $4-7$ & $1-3$ & $8-10$ & $0.39(0.24-0.65)$ & $0.16(0.06-0.42)$ & $0.03(0.00-0.20)$ & $10(5-15)$ \\
\hline 1001 & $\leq 50$ & Others & Others & $4-7$ & $4-7$ & 0 & $0.40(0.29-0.55)$ & $0.16(0.09-0.31)$ & $0.03(0.01-0.11)$ & $10(7-14)$ \\
\hline 1002 & $\leq 50$ & Others & Others & $4-7$ & $4-7$ & $1-3$ & $0.30(0.20-0.45)$ & $0.10(0.04-0.21)$ & $0.01(0.00-0.05)$ & $8(6-11)$ \\
\hline 1003 & $\leq 50$ & Others & Others & 4.7 & 4.7 & $4-7$ & $0.21(0.12-0.39)$ & $0.05(0.02-0.16)$ & $0.00(0.00-0.03)$ & $6(4.9)$ \\
\hline 1004 & $\leq 50$ & Others & Others & $4-7$ & $4-7$ & $8-10$ & $0.29(0.16-0.54)$ & $0.09(0.03-0.30)$ & $0.01(0.00 \cdot 0.10)$ & $8(4-12)$ \\
\hline 1005 & $\leq 50$ & Others & Others & $4-7$ & $8-10$ & 0 & $0.36(0.23-0.55)$ & $0.13(0.06-0.30)$ & $0.02(0.00-0.11)$ & $9(6-13)$ \\
\hline 1006 & $\leq 50$ & Others & Others & $4-7$ & $8-10$ & $1-3$ & $0.26(0.16 \cdot 0.44)$ & $0.07(0.03-0.20)$ & $0.01(0.00-0.05)$ & $7(5-10)$ \\
\hline 1007 & $\leq 50$ & Others & Others & $4-7$ & $8-10$ & 4.7 & $0.18(0.09-0.38)$ & $0.04(0.01-0.15)$ & $0.00(0.00-0.03)$ & $6(3-8)$ \\
\hline 1008 & $\leq 50$ & Others & Others & $4-7$ & $8-10$ & $8-10$ & $0.26(0.13-0.49)$ & $0.07(0.02 \cdot 0.25)$ & $0.01(0.00-0.07)$ & $7(4-10)$ \\
\hline 1009 & $\leq 50$ & Others & Others & $8 \cdot 10$ & 0 & 0 & $038(0.21 \cdot 0.69)$ & $0.15(0.05-0.48)$ & $0.03(0.00-0.25)$ & $10(4-15)$ \\
\hline 1010 & $\leq 50$ & Others & Others & 8.10 & 0 & $1-3$ & $0.28(0.12-0.65)$ & $0.08(0.02-0.43)$ & $0.01(0.00-0.20)$ & $8(3-13)$ \\
\hline 1011 & $\leq 50$ & Others & Others & $8-10$ & 0 & 4.7 & $0.20(0.07-0.58)$ & $0.04(0.00-0.35)$ & $0.00(0.00-0.14)$ & $6(2-10)$ \\
\hline 1012 & $\leq 50$ & Others & Others & $8-10$ & 0 & $8-10$ & $0.27(0.11-0.71)$ & $0.08(0.01-0.51)$ & $0.01(0.00-0.28)$ & $7(2-13)$ \\
\hline 1013 & $\leq 50$ & Others & Others & $8-10$ & $1-3$ & 0 & $0.29(0.16-0.53)$ & $0.09(0.03-0.28)$ & $0.01(0.00-0.09)$ & $8(5-12)$ \\
\hline 1014 & $\leq 50$ & Others & Others & $8-10$ & $1-3$ & $1-3$ & $0.20(0.09 .0 .44)$ & $0.04(0.01-0.21)$ & $0.00(0.00-0.05)$ & $6(3-9)$ \\
\hline 1015 & $\leq 50$ & Others & Others & $8-10$ & 1.3 & $4-7$ & $0.13(0.05 \cdot 0.36)$ & $0.02(0.00-0.14)$ & $0.00(0.00-0.03)$ & $5(3-7)$ \\
\hline 1016 & $\leq 50$ & Others & Others & $8 \cdot 10$ & $1-3$ & $8 \cdot 10$ & $0.20(0.08-0.50)$ & $0.04(0.01-0.26)$ & $0.00(0.00-0.08)$ & $6(3-9)$ \\
\hline 1017 & $\leq 50$ & Others & Others & $8-10$ & 4.7 & 0 & $020(0.10 \cdot 0.40)$ & $0.04(0.01-0.16)$ & $0.00(0.00-0.03)$ & $6(4-9)$ \\
\hline 1018 & $\leq 50$ & Others & Others & $8-10$ & $4-7$ & $1-3$ & $0.12(0.05 \cdot 0.29)$ & $0.02(0.00-0.09)$ & $0.00(0.00-0.01)$ & $5(3-7)$ \\
\hline 1019 & $\leq 50$ & Others & Others & $8-10$ & $4-7$ & 4.7 & $0.07(0.02-0.22)$ & $0.01(0.00 \cdot 0.05)$ & $0.00(0.00-0.00)$ & $4(2-6)$ \\
\hline 1020 & $\leq 50$ & Others & Others & $8 \cdot 10$ & 4.7 & 8.10 & $012(0.04 \cdot 0.37)$ & $0.02(0.00-0.14)$ & $0.00(0.00-0.03)$ & $5(2-7)$ \\
\hline 1021 & $\leq 50$ & Others & Others & $8-10$ & $8-10$ & 0 & $0.17(0.08-0.35)$ & $0.03(0.01-0.13)$ & $0.00(0.00-0.02)$ & $6(3-8)$ \\
\hline 1022 & $\leq 50$ & Others & Others & $8 \cdot 10$ & $8-10$ & $1-3$ & $0.10(0.04 .025)$ & $0.01(0.00-0.07)$ & $0.00(0.00-0.01)$ & $5(3-6)$ \\
\hline 1023 & $\leq 50$ & Olhers & Others & $8-10$ & $8-10$ & 4.7 & $0.05(0.01-0.18)$ & $0.00(0.00-0.03)$ & $0.00(0.00-0.00)$ & $3(2-5)$ \\
\hline 1024 & $\leq 50$ & Others & Others & $8-10$ & $8-10$ & $8 \cdot 10$ & $0.09(0.03-0.28)$ & $0.01(0.00-0.09)$ & $0.00(0.00-0.01)$ & $5(3-6)$ \\
\hline
\end{tabular}



Rescanch Ethica coand

Sunnvbrook Campus

The Rescarch bullding 2075 anvew Avenue

Room 5133

Toronto, on

Canada MAN 3 HS

Tel 416.480.4276

Fax 416.480 .5814

\section{MEMO RA N D U M}

To:

Dr. E. Chow

Radiation Oncology TSRCC

From: Philip Hẻbert MD

Date: December 20, 2000

Subject: A Predictive Model for Survival in Metastatic Cancer Patients Attending an Out Patient Palliative Radiotherapy Clinic

\section{Project Identification Number: 418-2000 \\ Approval Date: $\quad$ December 20, 2000}

The Research Ethics Board of Sunnybrook \& Women's College Health Sciences Centre has conducted a review of the research protocol referenced above on the above captioned date and approved the involvement of human subjects as specified in the protocol.

The quorum for approval did not involve any member associated with this project.

The Research Ethics Board has procedures and responsibilities that are in accordance with the ICH Guidelines for Good Clinical Practice.

Should your study continue for more than one year you must request a renewal on or before one year from the approval date. Please advise the Board of the progress of your research annually and/or any adverse reactions or deviations which may occur in the future.

The above propect identification number has been assigned to your study. Pleaserefer 6 this number on all future correspondence.

Philip Tébert, MD., PhD., CCFP (C)

Chdir, Research Ethics Board 


\section{References}

1. Maher EJ. How long have I got doctor? Eur J Cancer 1994; 3:283-284

2. Lamont $E$, Christakis NA. Some elements of prognosis in terminal cancer. Oncology 1999; 13:1165-1170

3. Parkes CM. Accuracy of predictions of survival in later stages of cancer. BMJ $1972 ; 2: 29-31$

4. Heyse-Moore LH, Johnson-Bell VE. Can doctors accurately predict the life expectancy of patients with terminal cancer? Palliative Medicine 1987; 1:165166

5. National Hospice Organization (NHO) Newsline. 1992 Stats show continued growth in programs and patients. NHO Newsline 1993;3:1-2

6. Demer $C$, Johnston-Anderson AV, Tobin $R$, et al. Cost of hospice care: late versus early entry (abstract). Proc Am Soc Clin Oncol 1992;11:392

7. Addington-Hall JM, MacDonald LD, Anderson HR. Can the Spitzer quality of life index help to reduce prognostic uncertainty in terminal care? Br J Cancer 1990; 62:695-699

8. Klastersky J, Daneau D, Verhest A. Causes of death in patients with cancer. Eur J Cancer 1972; 8:149-154

9. Weeks JC, Cook EF, O'Day SJ, et al. Relationship between cancer patients' predictions of prognosis and their treatment preferences. JAMA 1998; 279:17091714

10. Reuben DB, Mor V, Hiris $\mathrm{J}$. Clinical symptoms and length of survival in patients with terminal cancer. Arch Intern Med 1988; 148:1586-1591

11. Tamburini $M$, Brunelli $C$, Rosso $S$, et al. Prognostic value of quality of life scores in terminal cancer patients. J Pain Symptom Manage 1996;1:32-41

12. Maltoni $M$, Pirovano $M, N a n n i ~ O$, et al. Biological indices predictive of survival in 519 Italian terminally ill cancer patients. J Pain Symptom Manage 1997; 13:1-9

13. den Daas, N. Estimating length of survival in end-stage cancer: A review of the literature. J Pain Symptom Manage 1995; 10:548-555 
14. Chow $E$, Harth $T$, Hruby $G$, et al. How accurate are physicians' clinical prediction of survival and the available prognostic tools in estimating survival times in terminally ill cancer patients? Clinical Oncology (In Press)

15. Vigano A, Dorgan M, Buckingham J, et al. Survival prediction in terminal cancer patients: a systematic review of the medical literature. Palliative Medicine 2000; 14: $363-374$

16. Evans $C, M c C a r t h y$ M. Prognostic uncertainty in terminal care: Can the Karnofsky index help? Lancet 1985; 1204-1206

17. Forster LE, Lynn J. Predicting life span for applicants to inpatient hospice. Arch Intern Med 1988; 148:2540-2543

18. Bruera E, Miller MJ, Kuehn N, et al. Estimate of survival of patients admitted to a palliative care unit: a prospective study. J Pain Symptom Manage 1992; 7:82-86

19. Maltoni M, Nanni O, Derni S, et al. Clinical prediction of survival is more accurate than the Karnofsky Performance Status in estimating life span of terminally ill cancer patients. Eur J Cancer 1994; 6:761-766

20. Maltoni M, Pirovano M, Scarpi E, et al. Prediction of survival of patients terminally ill with cancer. Cancer 1995; 75:2613-2622

21. Mackillop WJ, Quirt CF. Measuring the accuracy of prognostic judgements in Oncology. J Clin Epidemiol 1997; 50:21-29

22. Oxenham D, Cornbleet MA. Accuracy of prediction of survival by different professional groups in a hospice. Palliative Medicine 1998; 12:117-118

23. Vigano $A$, Dorgan $M$, Bruera $E$, et al. The relative accuracy of the clinical estimation of the duration of life for patients with end of life cancer. Cancer 1999; 86:170-176

24. Christakis NA, Lamont EB. Extent and determinants of error in doctors' prognoses in terminally ill patients: prospective cohort study. BMJ 2000 19:469473

25. Yates JW, Chalmer B, McKegney FP. Evaluation of patients with advanced cancer using the Karnofsky Performance Status. Cancer 1980; 45:2220-2224

26. Mor V, Laliberte L, Morris JN, et al. The Karnofsky Performance Status Scale: an examination of its reliability and validity in a research setting. Cancer 1984; 53:2002-2007 
27. Schonwetter RS, Teasdale TA, Storey $P$, et al. Estimation of survival time in terminal cancer patients: an impedance to hospice admissions? Hosp J 1990; $6: 65-79$

28. Ventafridda V, Ripamonti C, Tamburini $M$, et al. Unendurable symptoms as prognostic indicators of impending death in terminal cancer patients. Eur $\mathrm{J}$ Cancer 1990; 26:1000-1001

29. Grabowski CM, Unger JA, Potish RA. Factors predictive of completion of treatment and survival after palliative radiation therapy. Radiology 1992; 184:329-332

30. Tsamandouraki $K$, Tountas $Y$, Trichopoulos $D$. Relative survival of terminal cancer patients in home versus hospital care. Scan J Soc Med 1992; 20:51-54

31. Rosenthal MA, Gebski VJ, Kefford RF, et al. Prediction of life-expectancy in hospice patients: identification of novel prognostic factor. Palliative Medicine 1993; 7:199-204

32. Hardy JR, Turner $R$, Saunders $M$, et al. Prediction of survival in a hospital-based continuing care unit. Eur J Cancer 1994; 3:284-288

33. Allard $P$, Dionne $A$, Potvin $D$. Factors associated with length of survival among 1081 terminally ill cancer patients. J Palliative Care 1995; 11:20-24

34. Morita T, Tsunoda J, Inoue S, et al. The palliative prognostic index: a scoring system for survival prediction of terminally ill cancer patients. Support Care Cancer 1999; 7:128-133

35. Pirovano M, Maltoni M, Nanni O, et al. A New Palliative Prognostic Score: A first step for the staging of terminally ill cancer patients . J Pain Symptom Manage $1999,17: 231-239$

36. Harrell FE Jr, Lee KL, Matchar DB, et al. Regression models for prognostic prediction: advantages, problems, and suggested solutions. Cancer Treat Rep. $1985 ; 69: 1071-1077$

37. Harrell F. The PHGLM procedure . In: SUGI Supplemental Library User's Guide. Cary, North Carolina: SAS Institute Inc.;1983; 267-294

38. Concato J, Feinstein A, Holford $\mathrm{T}$. The risk of determining risk with multivariable models. Ann Int Med 1993; 118:201-210

39. Efron B, Gong G. An leisurely look at the bootstrap, the jackknife, and crossvalidation. American Statistician. 1983;37:36-48. 
40. Maltoni $M$, Nanni $O$, Pirovano $M$, et al: Successful validation of the patients prognostic score in terminally ill cancer patients. Italian multicentre study group on palliative care. J Pain Symptom Manage 1999;17:240-247

41. Karnofsky DA, Abelmann WH, Craver LF, et al. The use of nitrogen mustards in the palliative treatment of cancer. Cancer 1948;1:634-656

42. Karnofsky DA, Burchenal JH. The clinical evaluation of chemotherapeutic agents in cancer. In: MacLeod CM, ed. Evaluation of Chemotherapeutic Agents. New York: Columbia University Press 1949; 191-205

43. Madsen EL. Painful bone metastasis: efficacy of radiotherapy assessed by the patients; a randomized trial comparing $4 \mathrm{~Gy} \times 6$ versus $10 \mathrm{~Gy} \times 2$. Int J Radiat Oncol Biol Phys 1983;9:1775-1779

44. Barak F, Werner A, Walach N, Horn Y. The palliative efficacy of a single high dose of radiation in treatment of symptomatic osseous metastases. Int J Radiat Oncol Biol Phys 1987:13:1233-1235

45. Hoskin PJ, Price $P$, Easton $D$, et al. A prospective randomized trial of 4 Gy or 8 Gy single doses in treatment of metastatic bone pain. Radiother Oncol 1992;23:74-78

46. Rasmusson $B$, Vejborg I, Jensen $A B$, et al. Irradiation of bone metastases in breast cancer patients: $A$ randomized study with 1 year follow-up. Radiother Oncol 1995;34:179-184

47. Gaze MN, Kelly CG, Ken GR, et al. Pain relief and quality of life following radiotherapy for bone metastases: a randomized trial of two fractionation schedules. Radiother Oncol 1997;45:109-116

48. Jeremic $B$, Shibomoto $Y$, Acimovic $L$, et al. A randomized trial of three singledose radiation therapy regimens in the treatment of metastatic bone pain. Int $J$ Radiat Oncol Biol Phys 1998;42:161-167

49. Nielsen OS, Bentzen SM, Sandberg E, et al. Randomized trial of single dose versus fractionated palliative radiotherapy of bone metastases. Radiother Oncol 1998;47:233-240

50. On behalf of the Bone Pain Trial Working Party. $8 \mathrm{~Gy}$ single fraction radiotherapy for the treatment of metastatic skeletal pain: randomised comparison with a multifraction schedule over 12 months of patient follow-up. Radiother Oncol 1999;52:111-121 
51. Steenland $\mathrm{E}$, Leer $\mathrm{J}$, van Houwelingen $\mathrm{H}$, et al. The effect of single fraction compared to multiple fractions on painful bone metastases: a global analysis of the Dutch Bone Metastasis Study. Radiother Oncol 1999;52:101-109

52. Price $P$, Hoskin $P J$, Easton $D$, et al. Prospective randomized trial of single and multifraction radiotherapy schedules in the treatment of painful bony metastases. Radiother Oncol 1986;6:247-255

53. Okawa T, Kita M, Goto M. et al. Randomized prospective clinical trial of small, large and twice-a-day fraction radiotherapy for painful bone metastases. Radiother Oncol 1988;13:99-104

54. Kagei $K$, Suyuki $K$, Sherato $H$, et al. Prospective randomized trial of single high dose versus multiple fraction radiation therapy for the treatment of bone metastasis. Gan No Rinsho 1990;36:2553-2558

55. Niewald $M$, Tkocz $H$, Abel $U$ et al. Rapid course radiation therapy vs. more standard treatment: a randomized trial for bone metastases. Int $\mathrm{J}$ Radiat Oncol Biol Phys 1996;36:1085-1089

56. George S. Identification and Assessment of Prognostic Factors. Semin Oncol 1988; $15: 462-471$

57. Cox DR. Regression models and life tables. J Statist Soc B, 1972; 34: 187-220

58. Kaplan EL, Meier $P$. Non parametric estimation from incomplete observations. J Am Stat Assoc 1958; 53: 457-481

59. Mantel N. Evaluation of survival data and two new rank order statistics arising in its considerations. Cancer Chemother Rep 1966; 50: 163-170

60. Collett D. Modelling Survival Data In Medical Research. Chapman and Hall, London. First Edition 1994

61. The International Non-Hodgkin's Lymphoma Prognostic Factors Project. A predictive model for aggressive Non-Hodgkin's Lymphoma. N Engl J Med 1993; 329: $987-994$

62. Christensen E. Multivariate Survival Analysis Using Cox's Regression Model. Hepatology 1987; $7: 1346-1358$

63. Massacesi $C$, Norman $A$, Price $T$, et al. A clinical nomogram for predicting longterm survival in advanced colorectal cancer. Eur J Cancer 2000; 36: 2044-2052 
64. Schuchter L, Schultz DJ, Synnestvedt $M$, et al. A prognostic model for predicting 10-year survival in patients with primary melanoma. Ann Intern Med 1996; 125: $369-375$

65. Harrell F, Lee $K$, Mark D. Multivariable prognostic models: issues in developing models, evaluating assumptions and adequacy, and measuring and reducing errors. Statistics in Medicine 1996; 15: 361-387.

66. Marubini E, Valsecchi MG. Analyzing survival data for clinical trials and observational studies. John Wiley \& Son Ltd. 1996 England

67.SAS Institute Inc. SAS/STAT User's Guide, version 8. Cary, NC: SAS Institute.

68. Christakis NA, Escarce JJ. Survival of Medicare patients after enrollment in hospice programs. N Eng J Med 1996; 335: 172-178

69. Christakis NA. Predicting survival before and after hospice enrollment. Hospice J 1998; 13: 71-78

70. Schonwetter $R$, Jani $C R$. Survival estimation in non-cancer patients with advanced disease. Topics in Palliative Care, volume 4. Edited by Portenoy RK and Bruera E. Oxford University Press 2000

71. Speer DC, Robinson BE, Reed MP. The relationship between hospice length of stay and caregiver adjustment. Hospice J 1995; 10: 45-58

72. Apgar V. Proposal for new method of evaluation of newborn infant. Anesth Analg 1953; 32: 260-267

73. Apgar V, Holaday DA, James LS. Evaluation of the newborn infant - second report. JAMA 1958; 168: 1985-1988

74. Teasdale $G$, Jennett $B$. Assessment of coma and impaired consciousness. A practical scale. Lancet $1974 ; 2: 81-84$

75. Jennett $B$, Teasdale $G$. Aspects of coma after several head injuries. Lancet 1977; 1 : 878-881

76. Bruera E, Kuehn N, Miller M, et al. The Edmonton Symptom Assessment System (ESAS): A simple method for the assessment of palliative care patients. J Palliat Care 1991;7:6-9

77. Philip J, Smith WB, Craft $P$, et al. Concurrent validity of the modified Edmonton Symptom Assessment System with the Rotterdam Symptom Checklist and the Brief Pain Inventory. Support Care Cancer 1998;6:539-541 
78. Chang VT, Hwang SS, Feuerman M. Validation of the Edmonton Symptom Assessment Scale. Cancer 2000; 88:2164-2171.

79. Paice JA, Cohen FL. Validity of a verbally administered numeric rating scale to measure cancer pain intensity. Cancer Nursing 1997;20:88-93

80. Llobera J, Esteva M, Rifa J, et al. Terminal cancer: duration and prediction of survival time. Eur J Cancer 2000; 36: 2036-2043.

81. Steensma DP, Loprinzi CL. The art and science of prognosis in patients with advanced cancer. Eur J Cancer 2000; 36: 2025-2027.

82. Vigano A, Bruera $E$, Suarez-Almanzor ME. Terminal cancer syndrome: myth or reality? J Palliat Care 1999; 15: 32-29.

83. Coates A , Porzsolt $F$ and Osoba D. Quality of life in oncology practice: Prognostic value of EORTC QLQ-C30 scores in patients with advanced malignancy. Eur J Cancer 1997;33:1025-1030

84. Loprinzi CL, Laurie JA, Wieand HS, et al. Prospective evaluation of prognostic variables from patient-completed questionnaires. J Clin Oncol 1994; 12: 601-607

85. Ganz PA, Haskell CM, Figlin RA, et al. Estimating the quality of life in a clinical trial of patients with metastatic lung cancer using the Karnofsky Performace Status and the functional living index cancer. Cancer 1988; 61: 849-856

86. Coates A, Gebski V, Signorini D, et al. Prognostic value of quality of life scores during chemotherapy for advanced breast cancer. J Clin Oncol 1992; 10: 18331838

87. Ganz PA, Lee JJ, Siau J. Quality of life assessment. An independent prognostic variable for survival in lung cancer. Cancer $1991 ; 67: 3131-3135$

88. Jarvis GK, Northcott HC. Religion and differences in morbidity and mortality. Social Science and Medicine 1987;25:813-824

89. Phillips DP, Smith DG. Postponement of death until symbolically meaningful occasions. JAMA 1990; 263:1947-1951

90. Schoenbach VJ, Kaplan BH, Fredman L, et al. Social ties and mortality in Evans County, Georgia. American J of Epidemiology 1986; 123:577-591

91. Spiegel D. Essentials of psychotherapeutic intervention for cancer patients. Support Care Cancer 1995; 3: 252-256 
92. Blake-Mortimer J, Gore-Felton C, Kimerling R, et al. Improving the quality and quantity of life among patients with cancer: a review of the effectiveness of group psychotherapy. Eur J Cancer 1999; 35: 1581-1586

93. Spiegel D. Psychosocial aspects of breast cancer treatment. Seminars in Oncology 1997; 24 (Suppl 1): 1-47

94. Phillips DP, King EW. Death takes a holiday: mortality surrounding major social occasions. Lancet 1988; 2: 728-732.

95. Christakis NA. Timing of Referral of Terminally III Patients to an Outpatient Hospice. J of Gen Int Med 1994; 9:314-320

96. Verweij J. The prognosis of prognostic factors in phase I clinical trials (Editorial). Ann Oncol 2000; 11; 131-132

97. Bachelot T, Ray-Coquard I, Catimel G, et al. Multivariable analysis of prognostic factors for toxicity and survival for patients enrolled in phase I clinical trials. Ann Oncol 2000; 11: 151-156

98. Bentzen SM, Hoskin P, Roos D, et al. Fractionated radiotherapy for metastatic bone pain: evidence-based medicine or ...? Int J Radiat Oncol Bio Phys 2000; 46: $681-682$

99. Ratanatharathorn J, Powers WE, Moss WT, et al. Bone metastasis: Review and critical analysis of random allocation trials of local field treatment. Int J Radiat Oncol Biol Phys 1999; 44: 1-18

100. Maltoni M, Nanni O, Scarpi E, et al. Model for estimation of survival in patients with far-advanced cancer. Topics in Palliative Care, volume 4. Edited by Portenoy RK and Bruera E. Oxford University Press 2000

101. Laupacis A, Wells G, Scott Richardson W, et al. Users' guides to the medical literature. V. How to use an article about prognosis. JAMA 1994; 272: 234-237

102. McCusker J. The terminal period of cancer: definition and descriptive epidemiology. J Chron Dis 1984; 37: 377-385

103. Forster LE, Lynn J. The use of physiologic measures and demographic variables to predict longevity among inpatient hospice applicants. Am J Hospice Care 1989; $6: 31-34$

104. Shekelle PG, Woolf SH, Eccles M, et al. Clinical guidelines - Developing guidelines. BMJ 1999;38;593-596 